\title{
ANL Analysis of ZPPR-13A
}

compiled by P. J. Collins and S. B. Brumbach

$$
\text { ANL }-97003542
$$

\author{
Applied Physics Division \\ Argonne National Laboratory \\ P. O. Box 2528 \\ Idaho Falls, ID 83403-2528
}

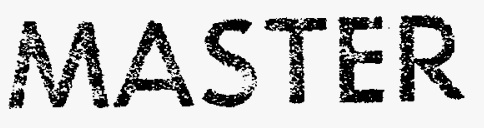

Work supported by the U. S. Department of Energy under Contract W-31-109-Eng-38. 


\section{DISCLAIMER}

This report was prepared as an account of work sponsored by an agency of the United States Government. Neither the United States Government nor any agency thereof, nor any of their employees, makes any warranty, express or implied, or assumes any legal liability or responsibility for the accuracy, completeness, or usefulness of any information, apparatus, product, or process disclosed, or represents that its use would not infringe privately owned rights. Reference herein to any specific commercial product, process, or service by trade name, trademark, manufacturer, or otherwise does not necessarily constitute or imply its endorsement, recommendation, or favoring by the United States Government or any agency thereof. The views and opinions of authors expressed herein do not necessarily state or reflect those of the United States Government or any agency thereof.

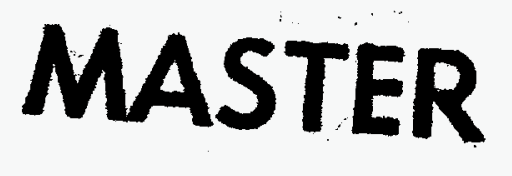


1.0 INTRODUCTION . . . . . . . . . . . . . . . 1

2.0 DESCRIPTION OF THE ASSEMBLIES AND MEASUREMENT

TECHNIQUES . . . . . . . . . . . . . . . . . . . . . . 7

2.1 General Features of Cell Design and Core Load ings . . . 7

2.2 The As semblies . . . . . . . . . . . . . . . 8

2.3 Experimental Techniques and Uncertainties....... 9

2.3.1 Critical Mass (k-effective) . . . . . . . . 10

2.3.2 Reaction Rate Measurements with Foils ..... 10

2.3.3 Reaction Rate Measurements with the

2.3.4 Reactivity Measurements . . . . . . . . . 13

2.3.5 Small-sample Reactivity Worths . . . . . . . 14

2.3.6 Doppler Coefficients . . . . . . . . . . 15

2.3.7 Summary of Experimental Uncertainties .... 15

3.0 CALCULATION METHODS . . . . . . . . . . . . . . 22

3.1 Cross Section Processing . . . . . . . . . . . . 22

3.2 Comparison of Results using the Buckl ing-recycle Method and Asymptotic Cell Processing.... . . . 24

3. 3 An isotropic Diffusion Coefficients . . . . . . . . 25

3.4 Reactor Models ................... . 26

3.5 More Complex Reactor Models and Asymmetry Effects . . . 28

3.6 Sensitivities and Eigenvalue Separations . . . . . . 32

4. 0 CRITICALITY PREDICTIONS, BETA, REACTIVITY COEFFICIENTS . . . 65

4. 1 Analys is of k-effective... . . . . . . . . . . 65

4. 2 Delayed Neutron Data .............. . . 66

4.3 Reactivity Coefficients............. 67

5.0 ANALYSIS OF REACTION RATE MEASUREMENTS . . . . . . . . . 73

5.1 Diffusion Theory Calculations for ZPPR-13A . . . . . 79

5.3 Reaction Rate Ratios . . . . . . . . . . . 98

5.4 Transport Calculations ............. 103

6.0 ANALYS IS OF CONTROL ROD WORTHS . . . . . . . . . . . 119

6.1 Diffusion Theory Calculations for $2 P P R-13 A$. . . . . 120

6.3 Control Rod Interactions .............. 138

6.4 Transport Calculations .............. 141 


\section{DISCLAIMER}

Portions of this document may be illegible in electronic image products. Images are produced from the best available original document. 
7.0 SODIUM VOID ANALYSIS . . . . . . . . . . . . 159

7. I Sodium Void Calculations for ZPPR-13A........ 159

8.0 DOPPLER REACTIVITY ................... 171

9.0 SMALL SAMPLE REACTIVITIES . . . . . . . . . . . 176

10.0 SUMMARY . . . . . . . . . . . . . . . . . 187

REFERENCES

$\frac{\text { Appendix } A}{\text { Specimen } M C^{2}}$ and SDX Input

Append ix B

Atoric Densities for $Z P P R-13$

Appendix C

Detailed Reaction Rate Data for ZPPR-13A 
1.1 Core/blanket configurations for the ZPPR-13 cores . . . . . 4

2.1 Typical loading pattern for a single-fuel-column drawer . . 16

2.2 Typical loading pattern for a double-fuel-colum drawer . . 17

2.3 Typical loading pattern for a blanket drawer . . . . . 18

3.1 ZPPR-13A: Ratios of reaction rates with "Multibuckled cell data" to those with "Asymptotic cell data"; $239 \mathrm{Pu}(n, f)$ and $238_{U}(\mathrm{n}, \mathrm{f})$........................

3.2 ZPPR-13A: Ratios of reaction rates with "Multibuckled cell data" to those with "Asymptotic cell data"; $235 \mathrm{U}(\mathrm{n}, \mathrm{E})$ and

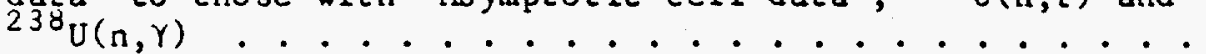

3.3 Calculated percent change in ${ }^{235} \mathrm{U}$ fission rate in $2 P P R-13 \mathrm{~A}$ when plate streaming is included . . . . . . . . . 39

$3.4 \mathrm{xy}$ calculation model for $2 P P R-13 \mathrm{~A}$ critical reference . . . 40

$3.5 \mathrm{rz}$ calculation model for 2 PPR-1 $3 \mathrm{~A}$ critical reference (dimensions in $\mathrm{cm}$ ) . . . . . . . . . . . ...

3.12 2PPR-13A: Correction factors for ${ }^{235} \mathrm{U}$ fission rates due to narrow drawers in blankets .............

3.13 Perturbation in ${ }^{235} \mathrm{U}$ fission rates in $\mathrm{ZPPR}-13 \mathrm{~A}$ due to detector drawers in blankets .............

3. 14 2PPR-13A: Locations of drawers with slightly greater or less than average fissile mass ............. 
3.15 Percent change in $235 \mathrm{U}$ fission rate in $2 P P R-13 \mathrm{~A}$ using specific fuel drawer masters compared to homogenized masters . . . . . . . . . . . . . . . . .

3. 16 Percent change in $235 \mathrm{U}$ fission rate in $2 \mathrm{PPR}-13 \mathrm{~A}$ using specific blanket drawer masters comparel to homogenized masters ................. . 52

3.17 Percent change in $235 \mathrm{U}$ fission rate in ZPPR-13A usi.ng all-master model compared to homogeneous model . . . . . . 53

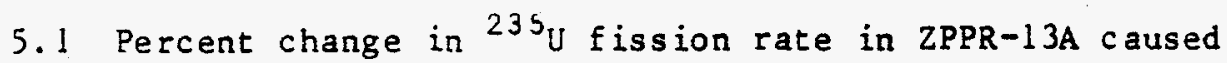
by partially inserted shim rods .......... . . 76

5.2 Radial variation of ${ }^{239} \mathrm{Pu}$ fission and ${ }^{239} \mathrm{U}$ capture in $\mathrm{ZPPR}-13 \mathrm{~A}$

5.3 Radial variation of ${ }^{239} \mathrm{Pu}$ fission and ${ }^{238} \mathrm{U}$ fission in ZPPR-13A....................

5.4 Foil locations in ZPPR-13A Irradiation No. 1...... 82

5.5 Foil locations in $2 P P R-13 A$ Irradiation No. 2...... 83

5.6 Ratio of calculation to experiment for $235_{\mathrm{U}} \mathrm{f}$ ission rates in 2 PPR-13A ................ 
6.1 Rod locations and $C / E$ values for the worths of ind iv idual rods in ZPPR-13A . . . . . . . . . . . . 123

6.4 One-dimensional model for study of higher-order transport effects in $2 P P R-13 A$. . . . . . . . . . . . 143

7.1 Interface diagram showing the reference configuration for the sodium-voiding experiments and showing the voiding zones in ZPPR-13A. Half 1........... 166

9.1 Measured and calculated radial reactivity worth profiles for the Pu-30 sample in ZPPR-13A ....... 178

9.2 Measured and calculated radial reactivity worth profiles for the U-6 sample in ZPPR-13A . . . . . . . . . 170 
9.3 Measured and calculated radial reactivity worth profiles for the KSS-1 sample in ZPPR-13A . . . . . . . . . . 180

9.4 Measured and calculated radial reactivity worth profiles for the B-1 sample in ZPPR-13A . . . . . . . . . 181

9.5 Measured and calculated radial reactivity worth profiles for the DU-6 sample in 2 PPR-13A . . . . . . . . . . . 182

9.6 Measured and calculated radial reactivity worth profiles for the $\mathrm{Fe}-1$ sample in ZPPR-13A . . . . . . . . 183

9.7 Measured and calculated radial reactivity worth profiles for the $C-1$ sample in $2 P P R-13 A$. . . . . . . . . . 184

\section{LIST OF TABLES}

1.1 Physical Characteristics of ZPPR-13A $\quad$. . . . 5

1.2 The Experimental Program in ZPPR-13A $\quad$. . . 6

2.1 Estimated Uncertainties for Experimental keff Values in ZPPR-13 . . . . . . . . . . . . . . . . . . . 20

2. 2 Summary of Experimental Uncertainties . . . . . . . . 21

3.1 Directional Diffusion Modifiers for ZPPR-13A D(Benoist)/ $\mathrm{D}$ (He terogeneous) ............... 59

3.2 Energy Structure of the Cross Section Sets used for ZPPR-13 Analys is . . . . . . . . . . . . 60

3.3 Variation in Average Composition of Drawer Masters in ZPPR-13A; Deviation in Mass ............. 61

3.4 Perturbation in Control Rod Worths in 2PPR-13A due to Variations in Master Loadings . . . . . . . . . . .

3.5 Characterization of the Eigenvalue Spectrum in the ZPPR-1 3 Series of As semblies ..............

3.7 Eigenvalue Separation for ZPPR-13 Cores . . . . . . . 63

3. 8 Sensitivity of Fission Rates in ZPPR-13A . . . 64

4.1 Experimental Values for $k_{e f f}$ in the $2 P P R-13$ Reference 


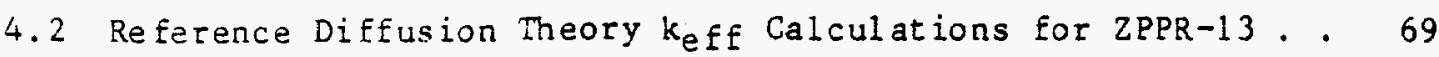

4.3 Mesh and Transport Corrections Derived for ZPPR-13A . . . 70

4:4 Comparison of $k_{\text {eff }}$ Results for a Range of ZPPR Cores . . . 71

4.5 Delayed Neutron Parameters for ZPPR-13 . . . . . . . . 72

4. 6 Mass Sensitivity Coefficients for $2 P P R-13$. . . . . . . 72

5.1 ZPPR-13A: Summary of Radial Reaction Rate Analysis . . . 85

5.2 ZPPR-13A: Summary of Radial Fission Rate Analysis for $235 \mathrm{U}$. . . . . . . . . . . . . . . . 86

5.3 2PPR-13A: Summary of Analys is for the Fission Chamber Cal ibration Foils . . . . . . . . . . . . . . 86

5.4 2PPR-13A: Summary of $235 \mathrm{U}$ Fission Near Control Rod Position in FR3 . . . . . . . . . . . . . . . . . 87

5.5 ZPPR-13A: Axial Reaction Rate Analys is in Matrix 147-42 . 87

5.6 ZPPR-13A: Axial Reaction Rate Analysis in Matrix 147-27. . 88

5.7 ZPPR-13A: Summary of Axial 235U Fission Rate Analysis . . . 89

5.13 ZPPR-1 3A: Summary of Reaction Rate Ratio Analysis . . . 112

5.16 ZPPR-13A: Transport Corrected Reaction Rates for $23{ }^{9} \mathrm{Pu}(\mathrm{n}, \mathrm{f})$. . . . . . . . . . . . . 115 


\section{LIST OF TABLES (cont.)}

Page

5.17 ZPPR-13A: Transport Corrected Reaction Rates for ${ }^{2} 3{ } U(n, f)$.................. 116

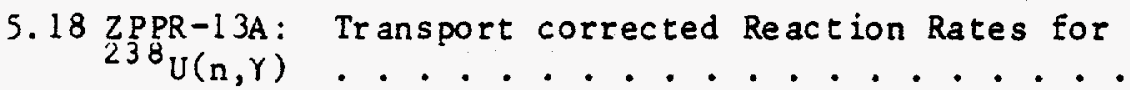

5.19 ZPPR-13A: Transport corrected Reaction Rates for ${ }^{238} \mathrm{U}(\mathrm{n}, \mathrm{f})$.................... 118

6.1 ZPPR-13A: Comparison of $x y z$ and $x y$ Calculations for Control Rod Worths . . . . . . . . . . . . . 124

6. 2 Contrul Rod Worth Analysis for the First Series of Me asurements in $2 P P R-13 A$. . . . . . . . . . . . 125

6. 3 Worths of CRPs Relative to Fuel for the First Series of Measurements in 2PPR-13A . . . . . . . . . . . . 126

6.4 Single Control Rod Worths for the Second Series of Measurements in 2PPR-13A . . . . . . . . . . . 127

6.5 Comparison of C/E Results for Single Control Rods in Left and Right Sides of ZPPR-13A . . . . . . . . . . . . 128

6.6 2PPR-13B/1: Comparison of $x y z$ and $x y$ Calculations for Control Rod Worths . . . . . . . . . . . . . 134

6. 7 Comparison of 28 Group and 8 Group $x y$ Calculations for Control Rod Worths . . . . . . . . . . . . . . 134

6.11 Comparison of Control Rod Worths in ZPPR-13A

6.12 Control Rod Interaction Effects in $2 P P R-13 A \ldots \ldots$

6.14 Variation in the Worth of a rod Bank with other Rods Inserted in the Core . . . . . . . . . . . . . . 
6.15 ZPPR-13A: Comparison of Diffusion and Transport Calculations for Control Rod Worths . . . . . . . . . 144

6.18 Comparison of $\mathrm{Transport}$ Corrections in $\mathrm{xy}$ and $\mathrm{r}-$ geometry for ZPPR-13A Control Rod Banks . . . . . . . .

6. 19 Higher Order Quadrature and Fine Mesh Effects for Control Rod Worths in $\mathrm{ZPPR}-13 \mathrm{~A} . \ldots . . . . . .$.

6.20 The Effect of Calculational Improvements on Control Rod Worth C/E values in ZPPR-13A . . . . . . . . . . . 148

7.1 ZPPR-13A Sodium-void Zone Measurement Results . . . . . . 168

7.2 Calculated Sodium-void Reactivity in ZPPR-13A . . . . . . 169

7. 3 Comparisons of Calculated and Measured Results for the 2PPR-13A Sodium-void Reactivity Experiments

8.1 Comparison of Measured and Calculated Doppler Reactivities for ZPPR-13A . . . . . . . . . . . 174

8. 2 Comparison of Measured and Calculated Values for $238 \mathrm{U}$ Doppler Sample Worth in Fuel Rings of ZPPR-13A 


\section{LIST OF TABLES (cont.)}

Page

8. 3 Values of Average $C / E$ for $238 \mathrm{U}$ Doppler Measurements Compared with Average $(C / E)^{2}$ for $238 U(n, \gamma)$ Foil Me asurements in ZPPR-13A . . . . . . . . . . 175

9.1 Description of the Reactivity-Worth Samples used in ZPPR-13A.................... 185

9.2 Analys is of Reactivity Samples from Radial Traverses in ZPPR-13A and Comparison with Results from ZPPR-9 and $2 \mathrm{PPR}-10$. . . . . . . . . . . . . . . . 186 


\subsection{INTRODUCTION}

The 2PPR-13 experiments provide basic physics data for radial-heterogeneous LMFBR cores of approximately 700 MWe size. Assemblies 2PPR-13A, ZPPR-13B and ZPPR-13C comprised the JUPITER-II cooperative program between US-DOE and PNC of Japan. The measurements were made between August 1982 and April 1984. The core designs and the measurements were planned jointly by the two parties with substantial input from U.S. industrial interests (GE-ARSD, W-AESD) to ensure coverage of the design requirements.

This report describes in detail the results of the ANL analyses of phases $13 \mathrm{~A}$

The data were compiled primarily for discussions at the Third Jupiter Analys is Meeting to be held at ANL-West between September 11 th and $14 \mathrm{th}, 1984$.

The Jupiter-I program covered experiments in conventional cores of similar size to ZPPR-13. ANL analyses of these data are described in Ref. 1 (ZPPR-9) and Ref. 2 (ZPPR-10).

The 2PPR-13 assemblies possessed the common features of a large central blanket zone, two internal blanket rings and three fuel zones of the same average enrichment. The cores were surrounded radially and axially by uranium oxide/sodium/steel blanket regions and by steel reflectors. The core height was $0.916 \mathrm{~m}$ and the fissile loading was about $2500 \mathrm{~kg}$ in each assembly.

The fuel and internal blanket arrangements for the $2 P P R-13$ series are shown in Fig. 1.1.

The physical

character istics of the $2 P P R-13 A$ are given in Table 1.1. The values in Table 1.1 refer to the reference critical configurations In the design of the cores, the basic internal blanket arrangements were chosen first. Small adjustments were made to 
fuel and blanket boundaries to obtain peak/average power densities which were within reasonable 1 imits, generally less than 1.3 ; but 1 ittle attempt was made at opt imization.

The experimental program was designed to follow changes in core properties in progressing from a simple benchmark, $Z P P R-13 A$, to a power reactor design,

A major concern in the large heterogeneous cores is the ability to predict spatially varying parameters. Consequently, measurement of reaction rate distributions and control rod worths comprised the principal measurements in each phase. Data on most other integral parameters were taken in $Z P P R-13 A$

The measurements made in each assembly are shown in Table 1.2. The analys is of $2 P P R-13$ used ENDF/B-IV data for two reasons: First, for consistency with past analysis of $2 P P R$ so that the $2 P P R-13$ cores could fill in gaps in the existing data base. Second, because at the start of the program the ENDF/B-V data were in the process of revision.

The reference model for each phase was three-dimensional (xyz) diffusion theory calculated with 28 group data. Since a vast number of calculations were required for analysis of control rod worths and for reduction of the experimental data; these were made in two-dimensional ( $x y$ ) geometry and 8 groups. However, 28 group xyz calculations were also made for the principal rod banks in each phase. Two-dimensional models were also used to study asymetry effects and transport corrections. These calculations will be described in detail in the subsequent sections.

In addition to the reference calculation, three special studies have been made for $2 P P R-13 A$ :

(i) Comparisons of calculations with ENDE/B-IV data and ENDF/B-V.2 (the second and final revision). 
(ii) A Yonte Carlo calculation with the VIM code.

(iii) Calculations with the recently developed nodal-diffusion and nodaltransport codes.

These studies will be reported as special topics. 

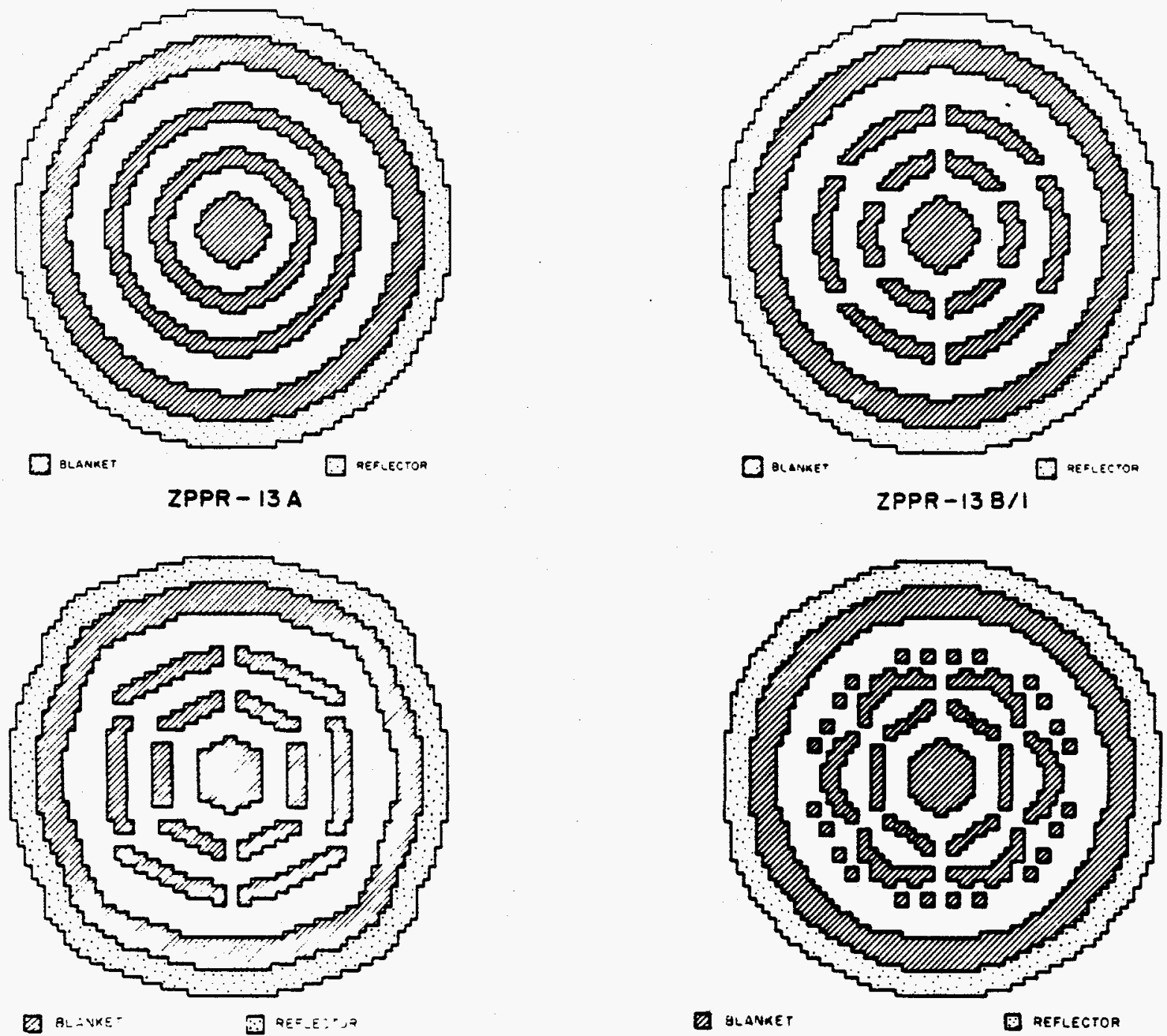

ZPPR - 13B/2

ZPPR - $138 / 3$

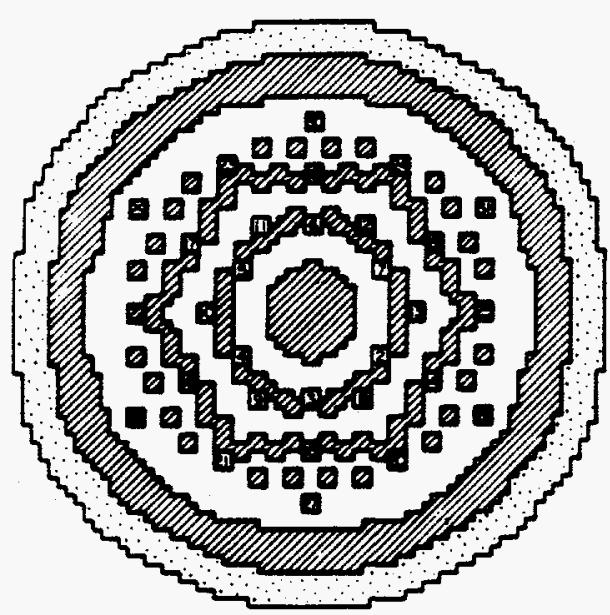

alanker
control soo mosition 0 agklectua

$Z P P R-13 B / 4$

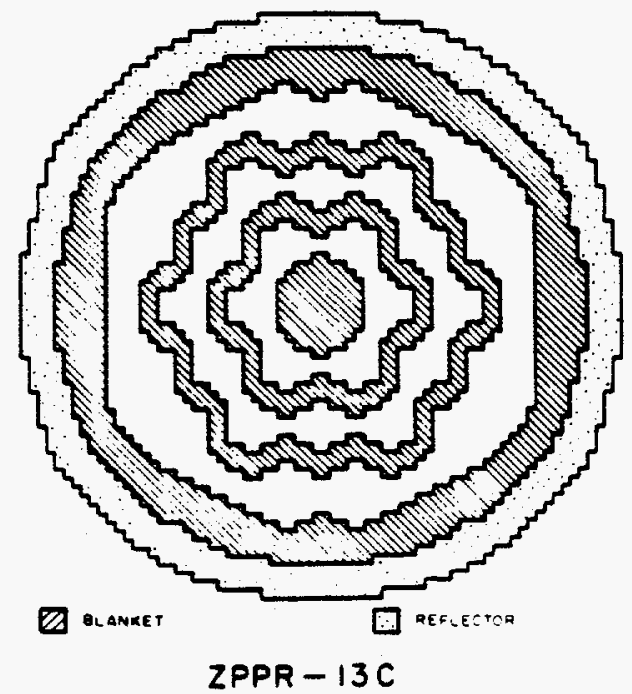

Fig. 1.1. Core/blanket configurations for the ZPPR-13 cores. 


\section{ZPPR-13A}

Core Volume, $\mathrm{L}^{\mathrm{a}}$

Effective Radius, $\mathrm{m}^{\mathrm{a}}$

$239 \mathrm{Pu}$ Mass, kg

Total Fissile Mass, $\mathrm{kg}$

$238 \mathrm{U}$ Mass, $\mathrm{kg}^{\mathrm{b}}$

Core Regions

Internal $\mathrm{Bl}$ anket

Radial Blanket

Axial Blanket

Total Euel Drawers

Total Internal

$\mathrm{Bl}$ anket Drawers

Fraction of DoubleFuel-Column Drawers ${ }^{d}$
5715.472

1.995

2435.060

2513.073

8332.193

16313.678

21572.243

10200. 764

aFuel plus internal blanket zones.

bInternal and radial blankets are $\pm 788 \mathrm{~mm}$. Core region is $\pm 458 \mathrm{~mm}$. Axial blanket is \pm 458 to $\pm 788 \mathrm{~mm}$.

cIncludes sodium-filled control rod positions.

dCore average. 
TABLE 1.2 . The Experimental Program in ZPPR-13A

$\underline{Z P P R-13 A}$

Date of first critical $8-5-82$

Approach to critical

Criticality

Reaction Rates:

Detailed $x y$

Limited $x y$

Axial

$\bullet$

Control Rod Worths:

Single Rods

Rod Banks

$\bullet$

Rod Interactions

Pin Rods

Large Rod Sizes

CPR/Fuel Reactivity

Sodium Void

Doppler Coefficient

Reactivity Samples:

Traverses

Drawer Oscillator

Kinetics Measurements

a ZPR-13B/2 was subcritical by 3.6\$. Reaction Rates were measured with the 64 incore fission chambers. 


\subsection{DESCRIPTION OF THE ASSEMBLIES AND MEASUREMENT TECHNIQUES}

\subsection{General Features of Cell Designs and Core Loadings}

Previous experience with smaller heterogeneous cores ( 350 MWe) and larger homogeneous cores (700-900 MWe) had inf icated the need for maximum simplicity and uniformity in cell designs. The following constraints were imposed at the outset:

(i) Use of a single type of flel throughout -- the $2 P P R$ Pu/U/Mo metal fuel using plutonium with $11 \% 240_{\mathrm{Pu}}$ content. This 1 imited the core sizes to a little less than $2500 \mathrm{~kg}$.

(ii) Use of cells symmetric in placement of plutonium and uranium plates within a drawer.

Five basic cell designs were used in all cores of the series: singlefuel-column, double-fuel-column, internal and radial blanket, axial blanket and steel reflector. The plate loadings of the cells are shown in Fig. 2.1, 2.2 and 2. 3.

In practice, many detailed variations about the basic cell loadings were necessary because of inventory 1 imitations and operational/experimental requirements. These were:

(i) Variations in piece length distributions making up the fuel and sodiun columns in a drawer.

(ii) Variations in ZPPR fuel by "vendor type" (Vendor-65, Vendor-63).

(iii) Variations in sizes of individual uranium oxide, uranium metal and steel plates.

(iv) Narrow drawers required to accommodate the $2 P P R$ safety/shim rod blades.

(v) Special drawers for in-core fission chambers.

(vi) Thermocouple drawers. 
In itially, narrow blanket drawers and blanket detector drawers contained less $23 \ell_{U}$ than standard blanket drawers. This mass difference and other small variations in drawer loading had significant effects on the measured parameters, as will be discussed in detail in subsequent sections.

Other, less important, deviations from an ideal, uniform, loading imposed by inventory 1 imitations occurred in the upper reaches of the axial blanket and in the radial reflector.

Changes in fuel enrichment were achieved by changing the ratios of single-fuel-column (SFC) drawers to double-fuel-column (DFC) drawers. Exactly the same ratio could not be obtained in each fuel region, but these proportions were made as close as possible. All fuel and blanket loadings were symmetric in the four quadrants, but the SFC and DFC drawers were not symmetric about the quadrant bisector (resulting in differences of several percent in fluxes between the $x$ and $y$ axes). This latter feature was not regarded as important since analyses would necessarily be made in $x y$ or xyz geometry and little uncertainty in the evaluation of the data was expected. Other asymmetries were caused by the narrow drawers and detector drawer placements. The former are constrained by locations available in the ZPPR machine. The latter were placed in asymmetric positions in order to provide maximum utility in coverage of the whole core.

\subsection{The As semblies}

ZPPR-1 $3 A$ was designed to be a benchmark core for the series. Internal blanket zones were continuous and all regions had closely cylindrical out ines. The reactor loadings prohibit direct use of an $r 2$ model for detailed comparison with experiment, but the calculation of reactor-average properties ( $k_{e} f$, Beff) are reasonably accurate and transport/diffusion theory corrections are facil itated in this geometry. 
ZPPR-13B/L retained the basic zone out 1 ine of $13 \mathrm{~A}$, but gaps were

introduced into the two internal blanket rings as a first step in the progression towards more prototypic cores. Reaction rates and control rod wurths were measured for comparison with analyses of ZPPR-13A, Fig. 2.4 compares fission rates in $-13 \mathrm{~A}$. This figure explains the changes in most measured parameters.

\subsection{Experimental Techniques and Uncertainties}

Most of the experimental methods usad in $2 P P R-13$ have been in standard use at $Z P P R$ and are described in the TM reports. Several refinements were found necessary due to the sensitivity of the larger heterogeneous cores. Some 
new techniques for sample reactivity worth measurements were used in $2 P P R-13$, following results from the ANL diagnostic core series in ZPR-6, 2PR-9 and ZPPR-12. This section summarizes the principal points relevant to the analys is and the uncertainties estimated for each type of measurement.

\subsubsection{Critical Mass (k-effective)}

Uncertainties in the experimental critical mass are due to imprecision in material masses and locations, and core temperatures. For convenience in the analysis, adjustments are made for the reactivity of inserted shim rods, parked shim and safety rods and to a uniform temperature of $293 \mathrm{~K}$. The adjustments are conveniently expressed in $\Delta \mathrm{k}$ units using a calculated value for Beff. A number of less tractable features of the assembly are normally assigned experimental uncertainties. These are often relatively small and need be only crudely estimated.

The current assessment of uncertainties for experimental values of $k_{e f f}$ in $Z P P R-13$ is shown in Table 2.1. The total uncertainty of about $0.04 \% \Delta k(1 \sigma)$ is dominated by knowledge of the fuel mass. Consequently this varies but 1 ittle among all Pu/U oxide LMFBR criticals built at ZPPR. Many of the large uncertainties are correlated among the assemblies.

\subsubsection{Reaction Rate Measurements with Fo ils}

Four reaction rate types were measured in $2 P P R-13$ with foils: $239_{\mathrm{Pu}}(\mathrm{n}, \mathrm{f}), 235_{U}(\mathrm{n}, \mathrm{f}), 238_{U}(\mathrm{n}, \mathrm{\gamma}), 238_{U}(\mathrm{n}, \mathrm{f})$. The number of available plutonium foils and their recycle time 1 imits their use to a few traverses in the principal assemblies of the series. However, experience has shown that equivalent information on the ability to predict spatial power distributions in core regions is obtained with $235_{\mathrm{U}}$ foils. Thus extensive use is made of $235 \mathrm{U}$. For convenience in the analysis and to provide data directly relating to principal components of the neutron balance in the assemblies, the basic reaction 
rates measured in the foils are converted to "plate-average" and to "cellaverage" quantities using measurements with several foils in the unit cells and "split-plates", i.e. plates of half-thickness to include central foils or "cellaveraging foils".

The uncertainties in measured reaction rates may be considered in three categories:

(i) Statistical uncertaitties in the foil counting (these also include components for foil placement and correction for other isotopes).

(ii) Uncertainties in the cell-average/foil factors.

(iii) Uncertainties due to absolute calibration.

For analys is of reaction rate distributions between cells of

the same type, the statistical uncertainty is the major component. Measurements with multiple foils in cells at different locations generally ind icate good separabil ity between the cell fine-structure and the overall reactor reaction rates.

For comparison of a given reaction rate in different cells, the uncertainties in cell-average factors should be considered. For reaction rate ratios the calibration uncertainties must be taken into account together with the correlation implicit when a common denominator reaction, usually $239 \mathrm{Pu}(\mathrm{n}, \mathrm{f})$, is used.

Typical statistical uncertainties are about $0.8 \%$ for the three non-threshold reactions and about $1.5 \%$ for $238 \mathrm{U}(\mathrm{n}, \mathrm{f})$ with in the fuel and internal blanket regions. In the radial, axial and the large internal blanket the statistical uncertainties for the $238_{U}(n, f)$ reaction rate deteriorate rapidly with penetration, increasing from $2 \%$ to $20 \%$ or more. Th is is due to the attenuation of the high energy $f l u x$ and to the increasing importance of corrections for $235_{U}$ content in the foil. 
Uncertainties in the cell-average/foil factors are due to

statistics in the fine-structure measurement, calculated adjustments for gross reactor gradients and to the split-plate/whole-plate factor (Stanford-Robinson experiment). These uncertainties are about $2 \%$.

Uncertainties in the foil calibration are estimated to be $1.5 \%$. However systematic differences between ANL and UK techniques(3) of $3 \%$ in the $238_{\mathrm{U}}$ capture to ${ }^{239} \mathrm{Pu}$ fission ratio, of which $2 \%$ is due to the plutonium fission calibration, have yet to be explained.

Foil irradiations are made at a reactor power of approximately $1 \mathrm{~kW}$. The reactor is controlled by $2 P P R$ shim rods, which are narrow blades of $93 \%$ enriched $\mathrm{B}_{4} \mathrm{C}$ inserted in $1 / 2$ in. spaces in the matrix created by use of drawers of only $3 / 4$ normal width. The excess reactivity is kept to a minimum and for $Z P P R-13$ was in the range of $6 k$ to $13 k$. The shim rods produce perturbations in reaction rates at the midplane of about $1 \%$. To facilitate their modelling in the calculations, eight symmetrically disposed shim rods (four in each half) are used in the irradiation with equal insertion. The shim-rod perturbations have been checked in several cases using the 64 fission chamber system.

\subsubsection{Reaction Rate Measurements with the In-core Fission Chambers} The statistical precision obtainable with the sixty-four in-core fission chambers can be very high. In practice an uncertainty of about $0.1 \%$ is usually obtained to avoid overly long counting times in far-subcritical states. For reactivity measurements, using countrate ratios in each chamber, only the statistical uncertainties need be considered.

Because of the extensive core-coverage afforded by the fission chamber system, the fission chambers have been calibrated against $235_{\mathrm{U}}$ foils placed in normal cells in positions symmetric to the fission chambers. The 
cal ibration takes into account the variation in mass of the fission chamber depusits and the electronic biases. The cal ibration has been discussed by Ikegami. (4) Uncertainties in the calibration are est imated to be $1.5 \%$.

\subsubsection{Reactivity Measurements}

Large-scale reactivity measurements of control rod worths, zone sodium voiding and drawer substitutions are measured relative to a reference configuration by the modified-source-multipl ication (MSM) technique. (5) A reference state, subcritical by $10 k$ to $20 k$, is established and the reactivity scale (in dollars) is measured by inverse-kinetics analys is of the power history following a "rod-drop". The only calculated input required are the $\lambda_{i}$ values from the delayed neutron analysis. The experimental reactivity is insensitive to these data and an uncertainty of $0.7 \%$ is estimated from the statistical analysis.

\section{Calculated values for "detector efficienciẹ" and "effective} source ratios" are provided for determination of reactivity relative to the chosen $r$ ference. A 1 inear least-squares fit of the reactivity estimate from each detector versus efficiency ratio $(\varepsilon)$ results in a statistical uncertainty for the system reactivity of about $0.1 \%$. Measurements of asymetric perturbations in $2 P P R-13$ showed the need for improved estimates of the effective source ratio $\left(S_{R}\right)$. These can be obtained by an iterative method in which the cross. sections in the perturbed region are adjusted until a good fit to the detector countrates (relative to those in the refarence) is obtained. Numerical tests have shown that the result could be achieved by the relation $\left(1-\varepsilon^{2}\right) \simeq\left(1-S_{R}\right)$ (Ref. 6), thus eliminating the need for multiple calculations. The source ratios vary in the range 0.7 (for control rod banks worth about $\$ 20$ ) to 1.1 . As a result of the numerical tests, an uncertainty of $0.04\left(1-s_{R}\right)$ was assigned with a minimum uncertainty of $0.3 \%$. Additional uncertainty components arise from 
corrections for the (relative) ZPPR interface gap, temperature, and $241_{\mathrm{Pu}}$ decay. These are relatively small components for control rod worths, but may dominate in the case of sodium void reactivities.

2.3.5 Small-sample Reactivity Worths Smal1-sample reactivity worths were measured in $2 P P R-13$ using three techniques. These techniques were the radial and axial tube, the shim blade and the long-drawer oscillator. Radial tube measurements are made at the reactor midplane. The oscillator tube is accomodated by pushing the drawers along one row of both assembly halves back from the interface about $6.4 \mathrm{~mm}$. The axial tube is accommodated by using a special drawer with $12.7 \mathrm{~mm}$ of material removed from the center of the drawer. Small, encapsulated samples, usually with cylindrical or annular geometry are oscillated in and out of the core. Because of the perturbation caused by the presence of the tube, sample worths are also measured by other techniques. One new technique used in $2 P P R-13$ measurements is the shim-blade oscillator. A sample, normally a foil of fissile material, is attached to a ( $0.9 \mathrm{~mm}$ thick) stainless steel blade which is oscillated axially in the air gap between the top of the contents of a drawer and the matrix tube. Special drawers with a bottom thickness of 0.25 mu instead of the normal 0.75 are used to increase the thickness of the air gap to $2 \mathrm{~mm}$. Foils up to 0.5 thick are placed in a shallow depression in the blade and covered with $0.05 \mathrm{~mm}$ thick stainless steel to protect the samples during oscillation. In the long-drawer-oscillator technique, a special drawer, is loaded with core material and special samples of interest. The sample zone is oscillated axially in and out of the core. Sample worths are inferred from worth differences with and without the samples. For all techniques, worths are derived from the inverse-kinetics analys is of the output of the two experimental ex-core $\mathrm{BF}_{3}$ chambers. 
All three sample worth :echniques were used in $2 P P R-13$, but only the axial- and radial-tube measurement data have been processed and none of the measurements have been adequately analyzed.

Statistical uncertaintias in the tube-oscillator technique range from $0.2-0.6 \%$ for high worth samples. Other, larger, systematic uncertainties arise from uncertainties in temperature, sample position and half closure. These systematic uncertainties are estimated to be about $1-2 \%$ for high-worth samples.

\subsubsection{Doppler Coefficient}

The Doppler measurements at ZPPR use a cylindrical sample, sealed in Inconel, $305 \mathrm{~mm}$ long and $25.4 \mathrm{~mm}$ in diameter with a $3 \mathrm{~mm}$ hole in the center to accommodate thermocouples. Samples are heated in vacuum by a heating element wrapped around the Inconel capsule. Measurements are made in a single matrix location by oscillating the sample axially into and out of the core. Worth is inferred from inverse-kinetics analys is of the output of the two experimental ex-core $\mathrm{BF}_{3}$ chambers. Uncertainties in measured values are estimated to be about $2-4 \%$, based mostly on measurement reproducibil ity.

\subsubsection{Summary of Experimental Uncertainties}

Table 2.2 summarizes the uncertainties in the various measured quantities discussed in this report. For the sample worth measurements and the Doppler measurements, the random uncertainties are relatively small. For these measurements it is likely that not all sources of systematic uncertainty have been quantified or, perhaps, even identified. Thus, the Doppler, and small sample worth uncertainties are estimated from experience in repro-' duc ing results of similar measurements. 
$\underline{0}$

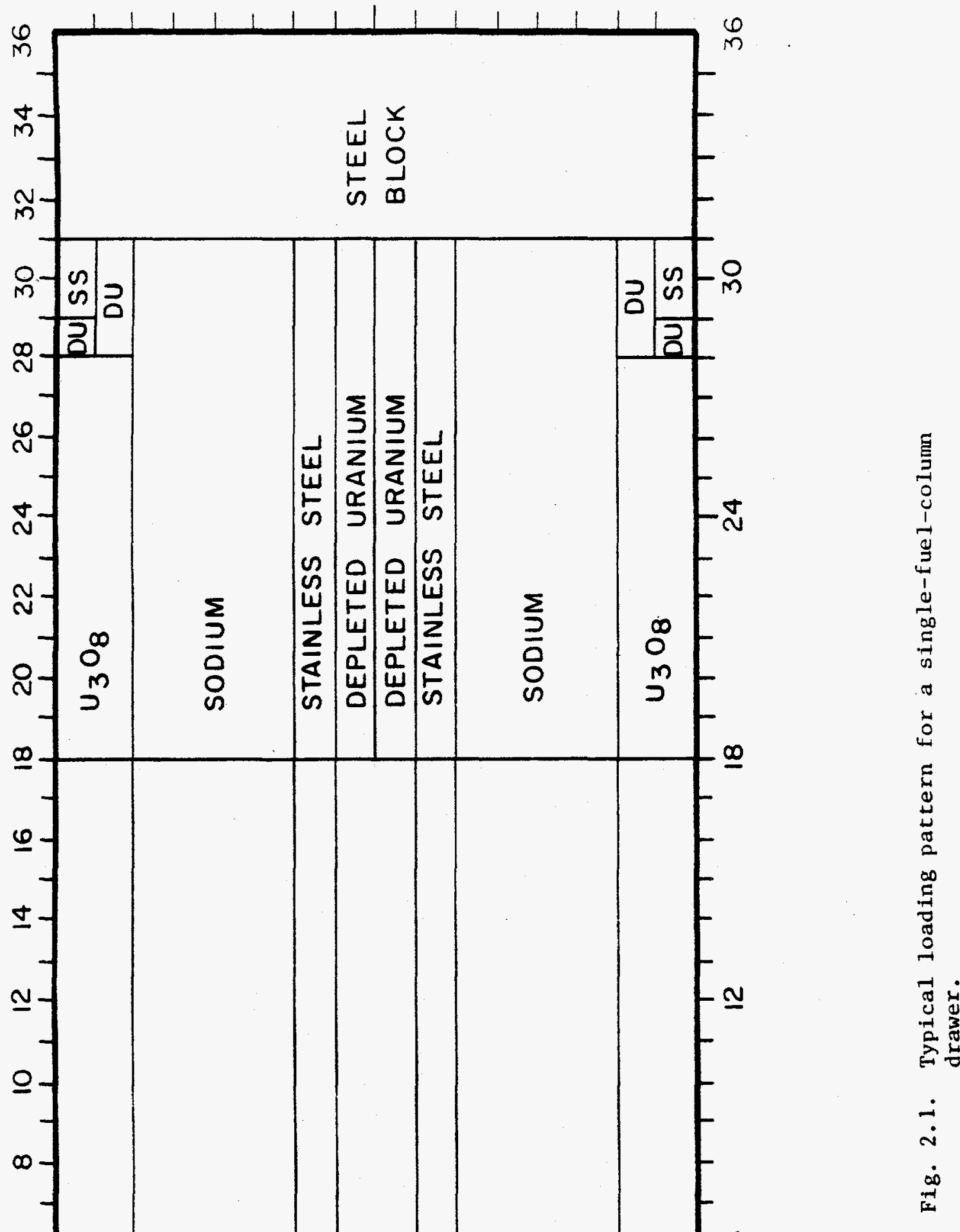




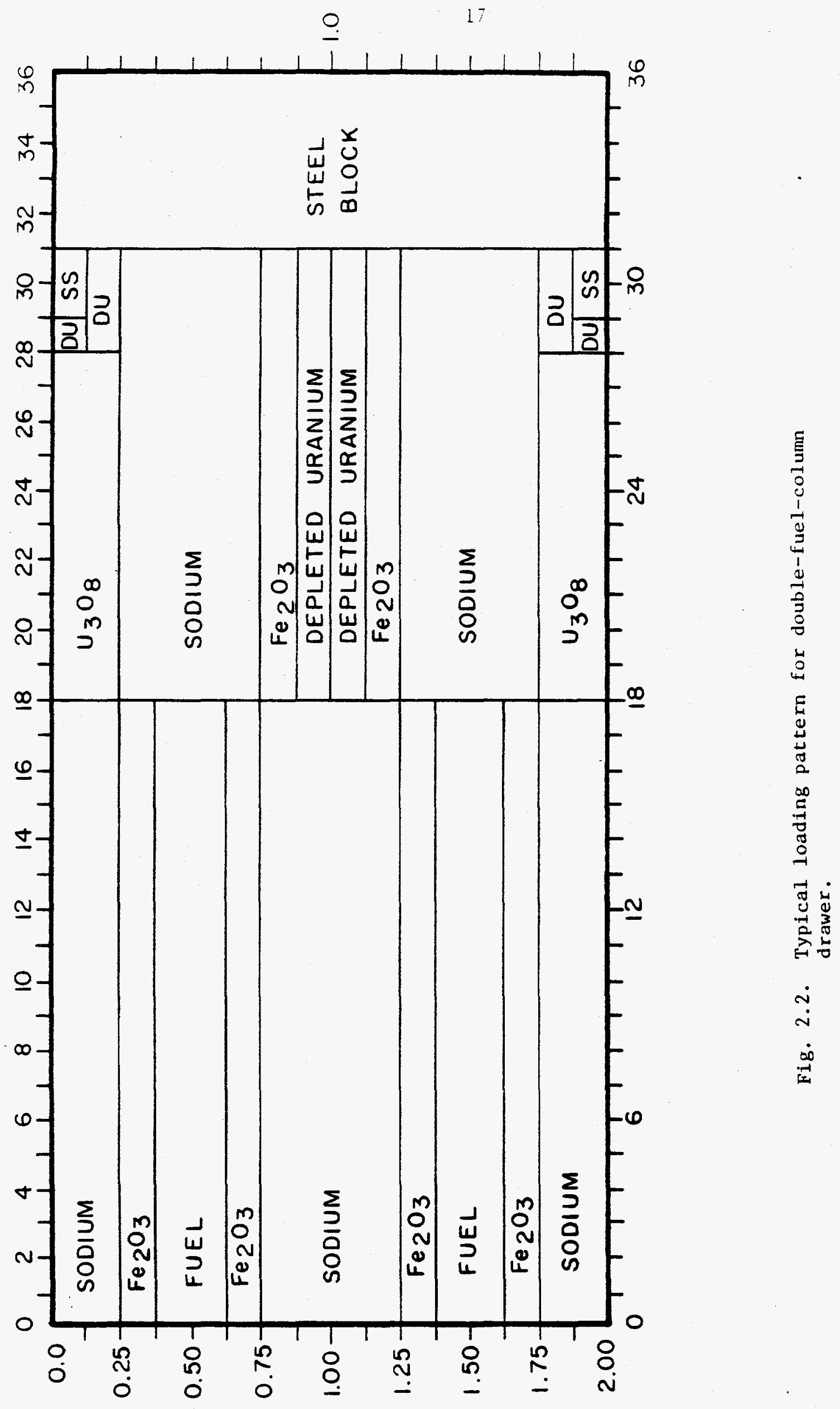




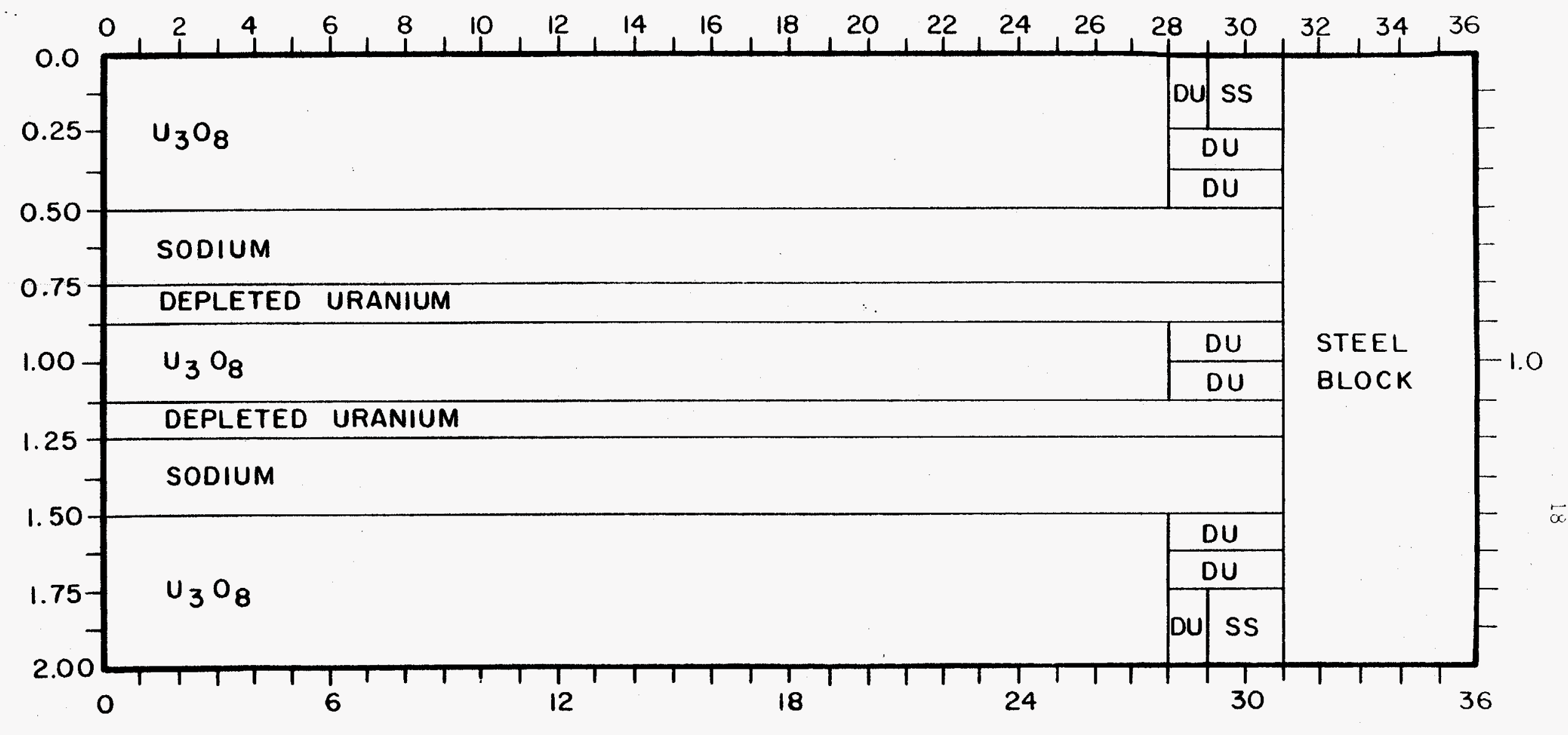

Fig. 2.3. Typical loading pattern for a blanket drawer. 


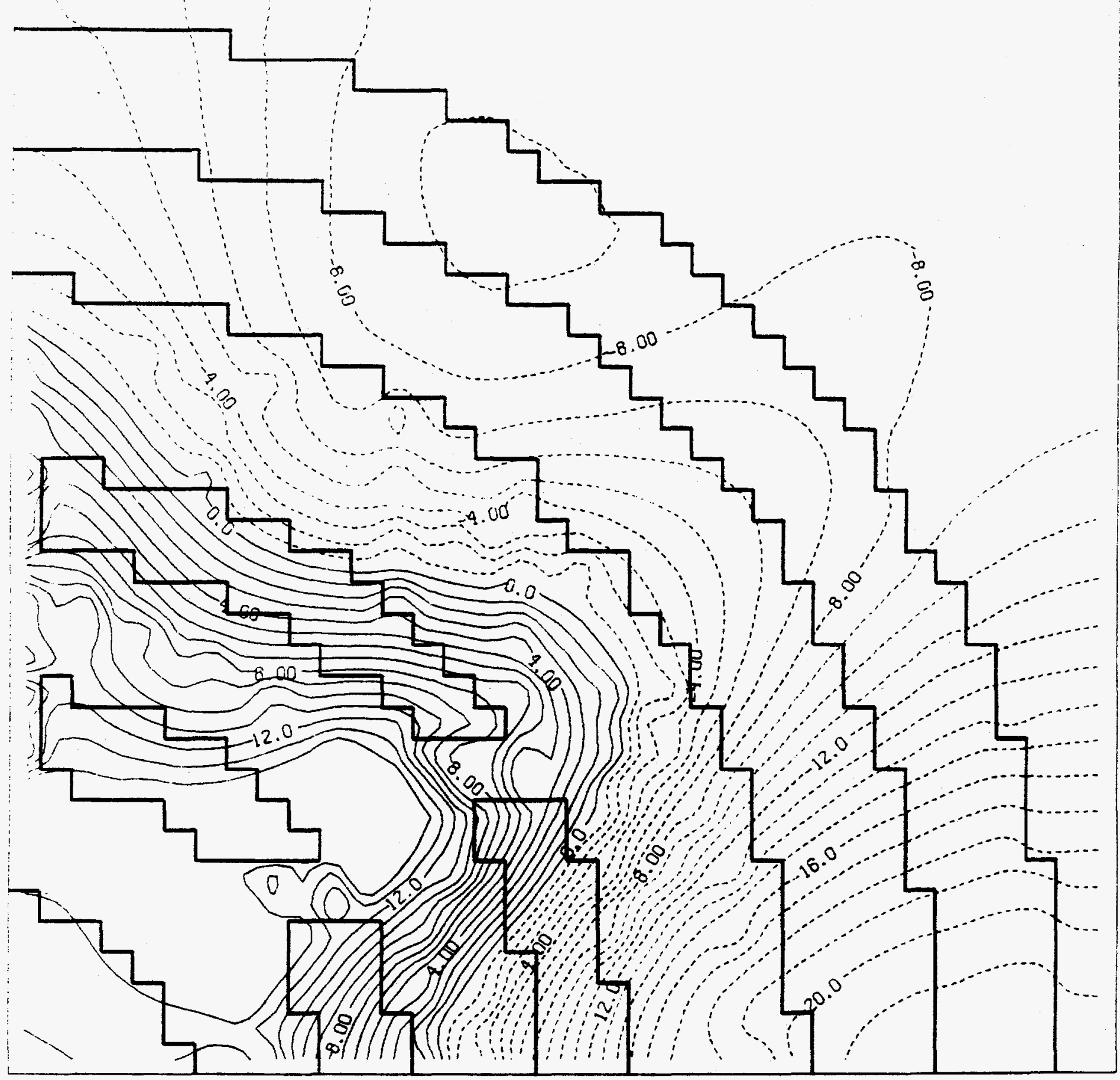

CANTQUR FROM -25.0CO TO 14.000 CQNTQUR INTERVAL OF $1.0000 \quad$ PT(3.3)= 13.430

Fig. 2.4. Calculated percent change in ${ }^{235} \mathrm{U}$ fission rates, $2 \mathrm{PPR}-13 \mathrm{~B} / 1$ compared to 2PPR-13A. 
Estimated Uncertainties for Experimental $k_{e f f}$ Values in $2 P P R-13$

Estimated 10 Uncertainty, $\% \Delta \mathrm{k}$

\section{$13 A$}

a. Measured excess:

period measurement 0.0008

b. Calculated Beff : 0.0025

c. Configuration reproducibility 0.0005

d. Material location 0.0066

e. Interface gap 0.0149

f. Core temperature ad justment:
thermocouple cal ibration
0.0017

average temperature 0.0033

temperature coefficient $\quad 0.0024$

g. $\quad 24 l_{\mathrm{Pu} \text { decay of fuel }}{ }^{\mathrm{a}} \quad 0.0100$

h. Void slots:

shim/PSR drawers 0.0066

fission chambers : $\quad 0.0090$

i. Isotopic composition 0.0320

j. Humidity 0.0002

k. PSR blades parked in plenum 0.0040

Statistical sum 0.0395

ancertainty in calculated decay from fabrication date 
TABLE 2. 2 . Sumary of Experimental Uncertainties

Measured Parameter

Typical Uncertainties ( $1 \sigma)$ Rand om (Statistical) Correlated

Critical Mass

(keff)

$0.01 \%$

$0.04 \%$

Reaction Rate Distributions

Core F9, F5, C8 F 8

$0.8 \%$

$1.5 \%$

$1-2 \%$

$2-30 \%$

$2 \%$

$2 \%$

$2 \%$

$2 \%$

Reaction Rate Ratios (Core region)

F5/F9, C8/F9

F $8 / F 9$

$1 \%$

$1.5 \%$

$2 \%$

$2 \%$

Control Rod Worths

$0.1 \%$ to $0.5 \%$

$1 \%$

Sodium Void Reactivity

$0.2 \%$

$1 \%$

Sample Traverses

High worth (fissile, $1 U_{B}$ )

C. $05 \mathrm{Ih} / \mathrm{kg}$

$1-2 \%$

Low worth and scattering

samples

Drawer Oscillation

$<0.5 \%$

$1-2 \%$

Doppler Effect

$<1 \% \quad 2-4 \%$

JAIIA16 


\subsection{CALCULATION METHODS}

\subsection{Cross Section Processing}

Calculations for ZPPR-13 used the ENDF/B-IV data. The generation of a multigroup 1 ibrary which includes treatment of heterogeneity effects in the unit cells used methods similar to those for JUPITER-I analysis $(1,2)$, with the following steps:

(i) Processing the ENDF/B files into a 2082 group library for the $M C^{2}-$ II code is done by the Methods and Computation Group in III inois using the ETOE code. This library is used in all neutronics calculations (with ENDF/B-IV) with in the Applied Physics Division at ANL.

(ii) Calculation of a 2082 group spectrum with $\mathrm{MC}^{2}-$ II and production of an "intermediate 1 ibrary" in 226 groups. This calculation was done once only, using the double-fuel-column composition.

(iii) Calculation of resonance shielding and flux fine-structure for each cell type using the SDX code with 226 groups, homogenization of the cross sections in each cell by $\mathrm{flux}$-volume weighting and collapse to 28 groups.

These methods are described in more detail in Refs. 1 and 2 . Several differences were invoked for $Z P P R-13$, principally as a result of studies in ZPPR-11 and 2PPR-12. These were:

(i) Improved treatment of resonance shielding for narrow resonances in iron, nickel, chromium, manganese, molybdenum, and sodium, following modifications to the $\mathrm{MC}^{2} / \mathrm{SDX}$ codes. For $\mathrm{ZPPR}-13$, data for these isotopes were shielded for the homogeneous cell compositions. Heterogeneous treatment is possible but leads to difficulties in equivalence theory between adjacent plates with the same isotopes. These improvements give an increase in $k_{e f f}$ of $0.1 \%$ for the $Z$ PPR cores which contain similar volume fractions of steel.

(ii) Cell calculations were made with group-dependent bucklings. The buckl ings were obtained from a prior xyz calculation for ZPPR-13A using microscopic 
cross sections generated for $2 P P R-11$. The 28 group fluxes were edited in the DIF $3 D$ code to provide the average leakages and bucklings for all occurrences of a given cell in a given zone of the reactor. The bucklings in the subset of 28 groups were used in the 2000 groups for $\mathrm{MC}^{2}$ and in the 226 groups for SDX. Some further details of the calculations were:

(a) The option to scale collision probabilities was used (rather than to add $\mathrm{DB}^{2}$ to $\Sigma_{t r}$ ).

(b) Since the one-dimensional cell models used "mid-cell densities and thicknesses", the impressed bucklings produced a $k_{\text {eff }}$ of about 1.1 . A modification to the codes was made to scale the bucklings by a constant factor to achieve the reactor k-effective of 0.980 . Since a given cell type will have a variety of neighboring cell-types in the actual loading, it is obvious that this prescription does not match any location exactly. It is further obvious that prediction of the correct flux shape within the cell would require consideration of the different leakages on the "left" and "right" sides of the cell. An improved scheme would require processing of an impracticably large number of cells and vast complications in the application of the data in the reactor model. The average bucklings are a compromise, but have been shown to give improvements in calculations of the threshold fission rate and in sodium void reactions.

The cell calculations for ZPPR-13A used bucklings generated for each cell in each radial zone. Differences of about $1 \%$ in flux-advantage factors for a given cell between the zones were noted. It was decided to use different cross sections in each zone although the effectiveness, compared with a simple method of using an average buckling for all zones of the same type is not obvious. In addition, cross sections for the large central blanket were generated for inner and outer regions. The following processed cross sections were generated: 
- central blanket inner region ( $C B I$ ), outer region ( $C B D$ )

- fuel ring one, single column (FISC), double column (FIDC)

- blanket ring one (Bl)

- fuel ring two, F2 SC and F2 DC

- blanket ring two (B2)

- fuel ring three (F3 SC and F3 DC)

- radial blanket (RB)

- axial blanket $(A B)$, using bucklings in the $18 \mathrm{in.}-28$ in. region of the double-fuel-colum drawer. The axial blanket cell of the single-fuelcolumn drawer and axial blanket cells remote from the core were not processed, but the data from the principal cells were mixed with the appropriate homogeneous compositions.

- cross sections for the steel reflector regions were taken for the steel cross sections in the radial blanket.

The input data for the $M C^{2}-$ I I calculation and for SDX calculations of the two fuel cells in $r$ ing 2 are shown in Appendix A.

Microscopic cross sections processed for 2PPR-13A were used in all other assemblies with no additional cell calculations. Macroscopic cross sections for each phase were "remixed" with the appropriate average atomic densities. These densities are given in Appendix B. The date for $241 \mathrm{Pu}$ decay was fixed at January 1, 1982 for the 1 ibrary and was not adjusted for each as sembly.

3. 2 Comparison of Results using the Buckling-Recycle Method and Asymptotic Cell Processing

Cross sections were generated using the method used for conventional cores using the same SDX cell models as above, but with a buckling search to 
critical for fuelled-cells and a zero buckling for blanket cells. These cross sections were compared with the data generated with the reactor bucklings, in an rz-model of $2 P P R-13 A$. The calculations were done by M. Kawashima.

The k-effective values for the rz model differed by only $0.05 \%$ : Buckl ing-recycle data $k=0.977775$

As youptotic data $\quad k=0.977225$

A comparison of radial reaction rate distributions was made with the rz model. Figs. 3.1 and 3.2 compare the radial reaction rate distributions. Differences are about $1 \%$ for the three non-threshold reactions, but about $5 \%$ for $238_{U}$ fission. Changes for this reaction type significantly improve agreement with experiment.

A similar improvement was shown for analysis of $2 P P R-7$. (7) In that case cross sections were generated for a two-drawer cell-model with adjacent fuel and blanket cells.

\subsection{Anisotropic Diffusion Coefficients}

An isotropic diffusion coefficients were generated by the Benoist method. One-dimensional cell models wer used in which the plate regions were "stretched" over the lattice pitch. Sodium-plate regions included both steel clad and sodium core. The perpendicular matrix and drawer structure was "smeared" uniformly into all plates.

The anisotropic diffusion coefficients are implemented in the DIF 3D code as "modifier factors" which multiply the cell-average diffusion coefficients calculated with the SDX code $\left(D_{S D X}\right)$. Modifier factors for $Z P P R-13$ are shown in Table 3.1. The modifiers are defined as the ratios of $D_{x}$ (perpendicular to plates) and $D_{y}$ (parallel to plates), which is the same as $D_{z}$ in the one-dimensional model, to the $D_{S D X}$. Previous analysis used the ratios of $D_{x}$ and $D_{y}$ to the homogeneous diffusion coefficient $D_{\text {hom }}$ (see $\operatorname{Re} f .8$ ). 
Figure 3.3 shows the effect of plate streaming on calculated fission rates in $2 P P R-13 \mathrm{~A}$. This figure shows the ratio of $235_{U}$ fission for an $x y$ calculation with anisotropic D's to a calculation with the $D_{S D X}$ 's. The fluxes are normalized to the same total fission source in the reactor. Inclusion of streaming modified the fission distributions in the core by up to $1 \%$. Effects on reactivity worths are approximately twice those shown for fission rates. Inclusion of streaming generally improves agreement with experiment. The effects in the heterogeneous cores are quite complex. Since the peak fluxes are in the second fuel ring, streaming effects flatten the fission distributions both towards the core center and outwards into the radial blanket.

Since anisotropic diffusion coefficients are used in all calculations, corrections for streaming are not shown separately as in previous analyses. The effect on calculated $k_{e f f}$ is about $-0.3 \%(-0.1 \% \Delta k$ in the $x y-p l a n e$ and $-0.2 \% \Delta k$ in the $z-d i r e c t i o n)$. For sodium void analysis, the Benoist diffusion coefficients increase the leakage contributions by $30 \%$ to $40 \%$. Results of least squares fitting to experiment indicates that the Benoist method (in the cell model used here) overestimated the streaming effect in the sodium voided cells.

\subsection{Reactor Models}

Analys is of $Z P P R-13 A$ made more extensive use of three-dimensional ( $x y z$ ) models than in the past. The reference method used was:

- ENDF/B-IV data in 28 energy groups.

- Diffusion theory in xyz geometry, one-eighth core model (one quadrant, half-height).

- Mesh spacing of $55 \mathrm{~mm}$ in the $x y-p l$ ane (one mesh point per ZPPR drawer (IMPD)). The axial mesh-spacing was similar, but varied to match shim rod insertion (for reaction rate calculations) and axial zone boundaries. The core contained six equal intervals of $51 \mathrm{~mm}$ for the first $306 \mathrm{~mm}$ from the 
midplane, four incervals of between $25 \mathrm{~mm}$ and $50 \mathrm{~mm}$ up to the blanket boundary, and six intervals of $42 \mathrm{~mm}$ in the lower part of the axial blanket.

- Anisotropic diffusion coefficients were used in all calculations.

The xyz models are used for calculation of $k_{e} f f$, reaction rates, sample traverses and sodium void reactivity. Two-dimensional models in $x y$ and rz geometry are used to calculate mesh and transport effects and for special studies. Group and region dependent buckling terms for xy models are obtained from the leakages calculated in the xyz models. These generally lead to small errors in the $x y k_{\text {eff }}(\sim 0.01 \%)$ and in cire-region reaction rates (tenths of a percent). Specification of an $r z$ model is not unique in the cores with complex internal blanket and CRP arrangement. These models have been used to calculate transport corrections in $2 P P R-13 A$ and preliminary values of Beff for all cores.

The $x y$ and $r z$ models for $2 P P R-13 A$, are shown in Figs. 3.4 to 3.5 * Axial regions in the xyz models were the same as in the rz models.

A large number of calculation; are required for control rod experiments, both to obtain calculated worths and to derive detector efficiencies and source ratios required for analysis of the experimental data. These calculations are made with the following metlod:

- ENDF/B-IV data in 8 energy $\xi$ roups.

- Diffusion theory in xy geometry, using quarter-, half- or full-plan models as required.

- Mesh spacing of $55 \mathrm{~mm}$. 
- Group and region dependent buckling terms derived from the leakages at the core/axial blanket interface $( \pm 458 \mathrm{~mm})$.

The 8 group library is essentially the same as the 9 group 1 ibrary used in JUPITER-I analysis, and differs only in combination of the lowest energy group (upper energy $3 \mathrm{eV}$ ) with the group above. Group collapse is made for all regions in the reference model using the xyz fluxes. Data for control rods and CRPs are obtained fron an xyz calculation with a bank of rods (or CRPs) fully inserted in the second fuel ring. These data are used for control rods (and CRPs) in all locations.

The buckling terms are obtained by repeating the xyz calculations (reference, rod bank and CRP bank) in 8 groups. The buckl ing terms are used in the same way as the collapsed data; bucklings for the reference model in all zones, and bucklings for the control rod (CRP) in all locations.*

In each phase of $2 P P R-13$, the principal control rod banks were calculated with xyz models in both 28 groups and 8 groups for comparison with results from the $x y$ models. As will be seen in Section 6, the approximation in the two-dimensional models lead to errors in rod worths of less than $2 \%$.

Energy group structures of the $2082,226,28$ and 8 group data are shown in Table 3.2.

\subsection{More Complex Reaction Models and As ymmetry Effects}

The early measurements in $2 P P R-13 A$ showed unantic ipated differences between measurements in what were thought to be symetrically equivalent locations in the reactor. A series of investigations mounted to study this problem is described in Ref. 9.

One effect seen in this study was due to the variation in interface gap between the two halves of the ZPPR machine. Upon half-closure, the matrix

* Note that the buckl ing terms include effects of streaming in the $z$-direction, since the xyz model used anisotropic diffusion. 
is in contact at the top of the core and separated by about $1 \mathrm{~mm}$ at the bottom.

This has the effect of bringing fuel closer together at the top of the core than at the bottom. Fission rates at the top are about $1 \%$ higher and control rod worths are about $2 \%$ higher. This feature of the loading is exceedingly difficult to model in the calculations.

At a later stage, two features of the reactor loadings which affect the symmetry of the measurements were uncovered. These were:

(i) Asymmetries due to the loading of the "narrow drawers" used in blanket regions to accommodate the $Z$ PPR safety/shim rod blades.

(ii) Asymetries due to the loadings of fission-chamber drawers in blanket regions.

In both of these cases, a significant amount of uranium was removed from the cells. The effects were calculated using xy models (half $x y-p l a n$ for (i) and full $x y-p l$ an for $(i i)$ ).

Perturbations in fission rates due to the narrow blanket drawers for 2PPR-13A are shown in Fig. 3.12. Note that in addition to the effect on left to right symmetry, there is a sensible difference between points on the $x-a x$ is and the $y-a x$ is.

Perturbations due to blanket fission chamber drawers are a little more subtle. These are shown in Fig. 3.13. The asymetries largely result from a nonuniform distribution of the blanket fission chambers -- more are present in the upper-left-hand (ULH) quadrant of half-one than in the LRH quadrant. The perturbations affect fission rates between $l e f t$ and $r$ ight sides and also between the top and bottom of the interface.

Correction for these two effects resulted in much improved consistency between C/E values on the left and right sides of the core. $(10,11)$ 
A remaining characteristic of the analyses with the reference models was a marked difference in predictions of experiments at the $x$-axis and at the $y$-axis. For example, C/E values for control rods CR25 ( $x$-axis in F3) and CR28 ( $y$-axis in $F 3$ ) differed by $4 \%$ even after including the effects described above. ( 9 ) Diligent efforts by the $Z P P R$ analysts, in the face of rising torrents of experimental data, eventually revealed that most of this problem was due to variation in the fissile masses in the individual loadings of a generic drawer-master. This feature had not been considered important in any previous $2 P P R$ cores. It was found that perturbations in fission rates, compared with those calculated using homogenized compositions, arose from three principal effects:

(i) Use of two types of ZPPR fuel (Vendor 63 and Vendor 65) for which the fissile contents per plate differ by about $1 \%$

(ii) Use of four plutonium plates in a fuel column of a drawer instead of the more usual three plates (e.g. a 5 in., 5 in., 4 in., 4 in. loading compared with a 8 in., 6 in., 4 in. loading). This difference results in a decrease in fissile content of $0.5 \%$ to $1 \%$ compared with the average.

(iii) Variations in total uranium content anong the various specific blanket drawer masters.

The variations in ${ }^{239} \mathrm{Pu}$ and $238 \mathrm{U}$ for the $2 \mathrm{PPR}-13 \mathrm{~A}$ masters are shown in Table 3.3.

Given a uniform distribution over the core of each master type, these variations would result in local perturbations only. However, it transpired that in ZPPR-13A, the drawers with higher or lower fissile content than average tended to be grouped in certain areas. Thus an overall perturbation in reactor fission rates was produced. 
EEfects die to variation in uranium content were somewhat surpris ing, since the uranium worth is considerably lower than that for plutonium and variations were only about $0.5 \%$ from the average. However, the different masters were loaded selectively in regions at the axes and centered around $45^{\circ}$ to the axes. Figure 3.14 shows diagrammatically the locations of the most deviant masters for fuel drawers in $2 P P R-13 \mathrm{~A}$.

Calculations have been made to test the effect of variation in the drawer masters using an xy model. A computer code (called McMASTERS) has been written which takes the assembly loading record (on tape), scans through the matrix and automatically writes most of the input required for the DIF $3 D$ code. Since some of the masters are different between half-one and half-two of the reactor (fission chamber locations, thermocouple locations, radial reflector), the code scans both half-one and half-two loadings and, for the $x y$ model, uses an average composition for these cases. An auxiliary module (MCADEN) writes the composition of each master in ARC system format for data mixing. These codes will eventually form part of a general system for setting up ARC system calculat ions from the reactor loading records.

The fission chamber drawers in blanket regions presented an additional twist, since the uranium was removed only from the first 8 in. of the drawer. For these drawers weighted average atomic densities, $\overline{\mathrm{N}}$, were defined as: $\overline{\mathrm{N}}=0.545 \mathrm{~N}(0-8 \mathrm{in.})+0.455 \mathrm{~N}(8 \mathrm{in.}-18$ in. $)$.

The xy calculations were run in diffusion theory with the $55 \mathrm{~mm}$ mesh size and 28 group cross sections. To simplify the input, cross sections and buckl ings processed for middle fuel ring (F2), second blanket ring (B2) and radial reflector ( $R R$ ) were used throughout. The fission rates from the allmaster model (AMM) were compared with those using the model with homogenized composition (HMM). The same microscopic cross sections and bucklings for $F 2$ and B2 were used in the homogenized model. 
Eigure 3.15 shows the effects in $2 P P R-13 \mathrm{~A}$ of using individual masters for the fuel drawers. Figure 3.16 shows the effects of using individual masters for the blanket drawers. Figure 3.17 shows the effects of using all master, including narrow blanket drawers and blanket fission chamber drawers. In each case the fluxes are normalized to the same total fission source in the reactor.

It $c$ an be seen that the ind ividual effects are additive, to a good approx imation. That is, superposition of Figs 3.12, 3.13,3.14, 3.15, and 3.16 reproduces the total perturbations in Fig. 3.17 .

Perturbations to reactivity worths at different positions in the reactor are about double those for fission rates. Direct calculations for control rods CR25, CR28 and a bank of six rods in fuel ring 3 (6F3) for $2 P P R-13 A$ are shown in Table 3.4. Corrections to worths from the HMM model are within $0.2 \%$ of estimates from the fission rate perturbations in Fig. 3.17. Estimated currections for control rods in other positions have been made from the fission rate data.

\subsection{Sensitivities and Eigenvalue Separation}

A key parameter for describing large, heterogeneous LMFBR designs is the neutronic coupling between the core zones. It has become customary to refer to heterogeneous cores as loosely coupled or tightly coupled, depending on the sensitivity of the power distribution to local perturbations. Decoupling is generally introduced in designs by isolating the individual core zones with thick internal blanket rings. The degree of coupling (or decoupling) can be quantified by several parameters, but not all of them give a good picture of overall reactor behavior. In planning the $2 P P R-13$ experiments, the $\left(k_{i j}\right)$ 
matrix from the Avery theory of coupled reactors $(12)$ and the eigenvalue spectrum were chosen as decoupling descriptors. In applying the Avery theory, the reactor is arbitrarily divided into two parts, and the coupling between them is described by the elements of the $(2 \times 2) k_{i j}$ matrix. The eigenvalue spectrum is particularly useful if nodal kinetic analysis to be used.

For $2 P P R-13$, only the separation between the fundamental and the first harmonic eigenvalues* were used for analysis of the eigenvalue spectrum. Previous experience had shown that the first harmonic eigenvalue was always for an azimuthal mode, even if there were only two fuel $r$ ings separated by an unusually thick blanket. Intuitively one might expect the core to be more radially decoupled, but in general azimuthal decoupling dominates for local perturbations.

Approximate solutions for the first harmonic eigenvalue were obtained by imposing a zero-flux boundary condition along the $x$ or $y$ axis in a $1 / 8$-core, xy model of the assembly. Exact solutions were later obtained by stripping out the fundamental mode and solving directly for the first harmonic. It was demonstrated that the approximate solutions were sufficiently accurate provided that the zero-flux boundary condition was imposed along an ax is where there was a natural minimum in the reference flux solution. Application of this knowledge made prel iminary planning considerably easier.

For ZPPR-13, only the separation between the first two eigenvalues was considered as a measure of the relative decoupling. Table $3.5 \mathrm{gives}$ the percentage separation

\footnotetext{
*Here we refer to the eigenfunction closest to the fundamental as the first harmonic.
} 

Table 3.7 shows eigenvalue separation for $2 P P R-13$ cores, estimated for the 8 group models used for control rod analysis. Eigenvalues were obtained by forming a zero flux at the $x$-axis and at the $y$-axis in each case. In addition to the reference configuration, results are shown for control rod banks inserted in each ring in the subcritical states. The eigenvalue separations in the critical cores will depend on the changes made to bring the core critical. However, for a uniform increase in enrichment, it appears that the cores with control rods inserted may be far more sensitive than the references.

The response to a perturbation of the reactor ( $f l u x$ tilts) can be analyzed by an eigenfunction expansion. If $\psi_{i}$ are the eigenfunctions of the reference reactor, with eigenvalues $\lambda_{h}$,

$$
L \psi_{n}=\left(1 / \lambda_{n}\right) M \psi_{n}
$$

Wade ${ }^{(13)}$ has shown that the fluxes, $\phi$, in the perturbed case are given by:

$$
\phi(r)=a_{0} \psi_{0}(r)+\sum_{n} \frac{p_{n} \lambda_{n} \lambda_{n}}{\lambda_{0}-\lambda_{n}} \psi_{n}(r)
$$

where

$$
\rho_{n}=\left\langle\psi_{n}^{*},(-\delta L+\delta M) \phi\right\rangle\left\langle\left\langle\psi_{n}^{*}, M \psi_{n}\right\rangle\right.
$$

Thus, harmonics with the smallest eigenvalue separation dominate. Perturbations at the peak of the eigenfunction have maximum effect, while perturbations at the nodes will give zero contribution. 
The sensitivities of the cores to errors in cross section data can also be characterized by the eigenvalue spectra. Only a limited number of résults have been obtained for ZPPR-13 at this stage. Table 3.8 shows the results of a $5 \%$ increase in 238 capture, uniformly in all regions, for $2 P P R-13 A$ 


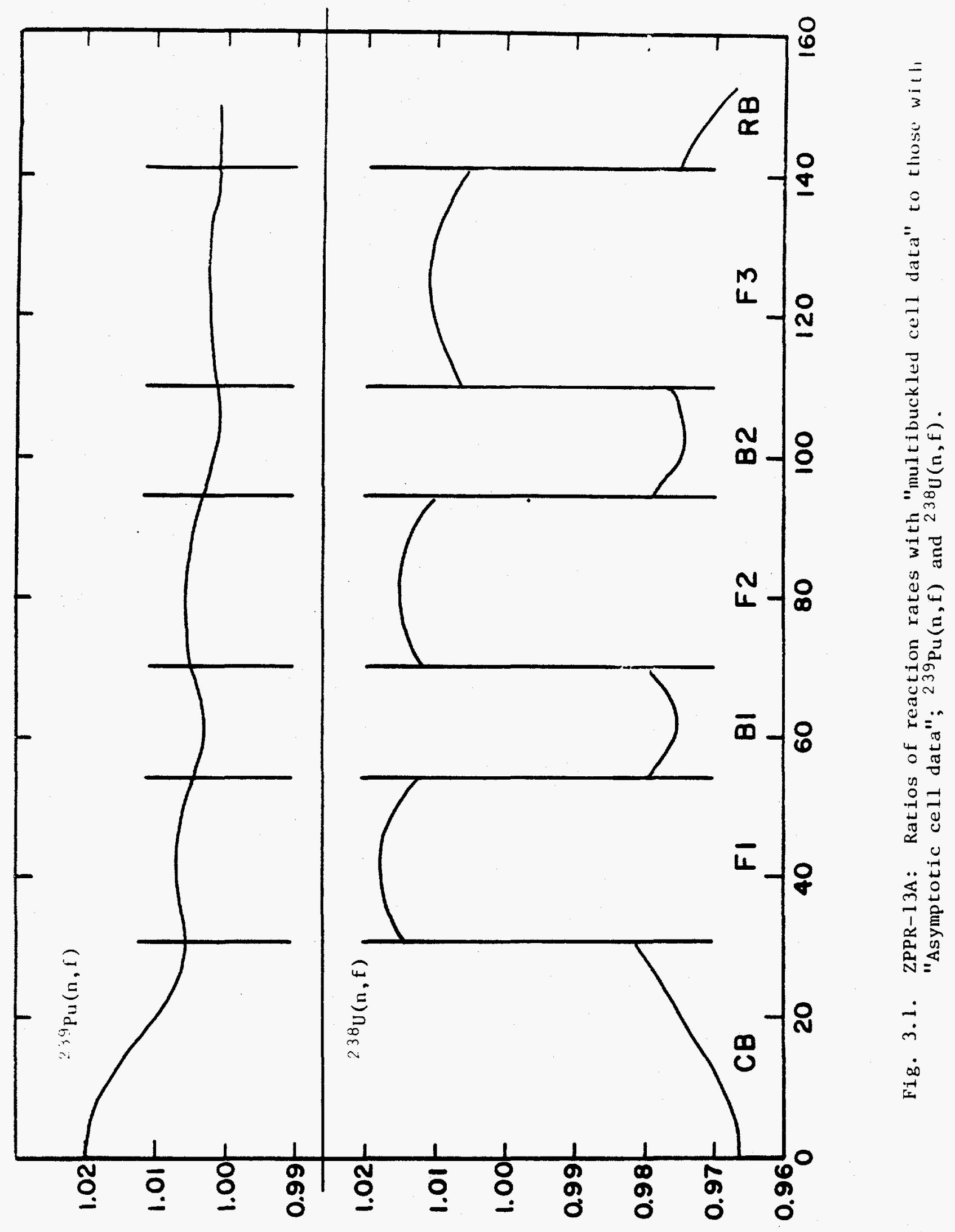




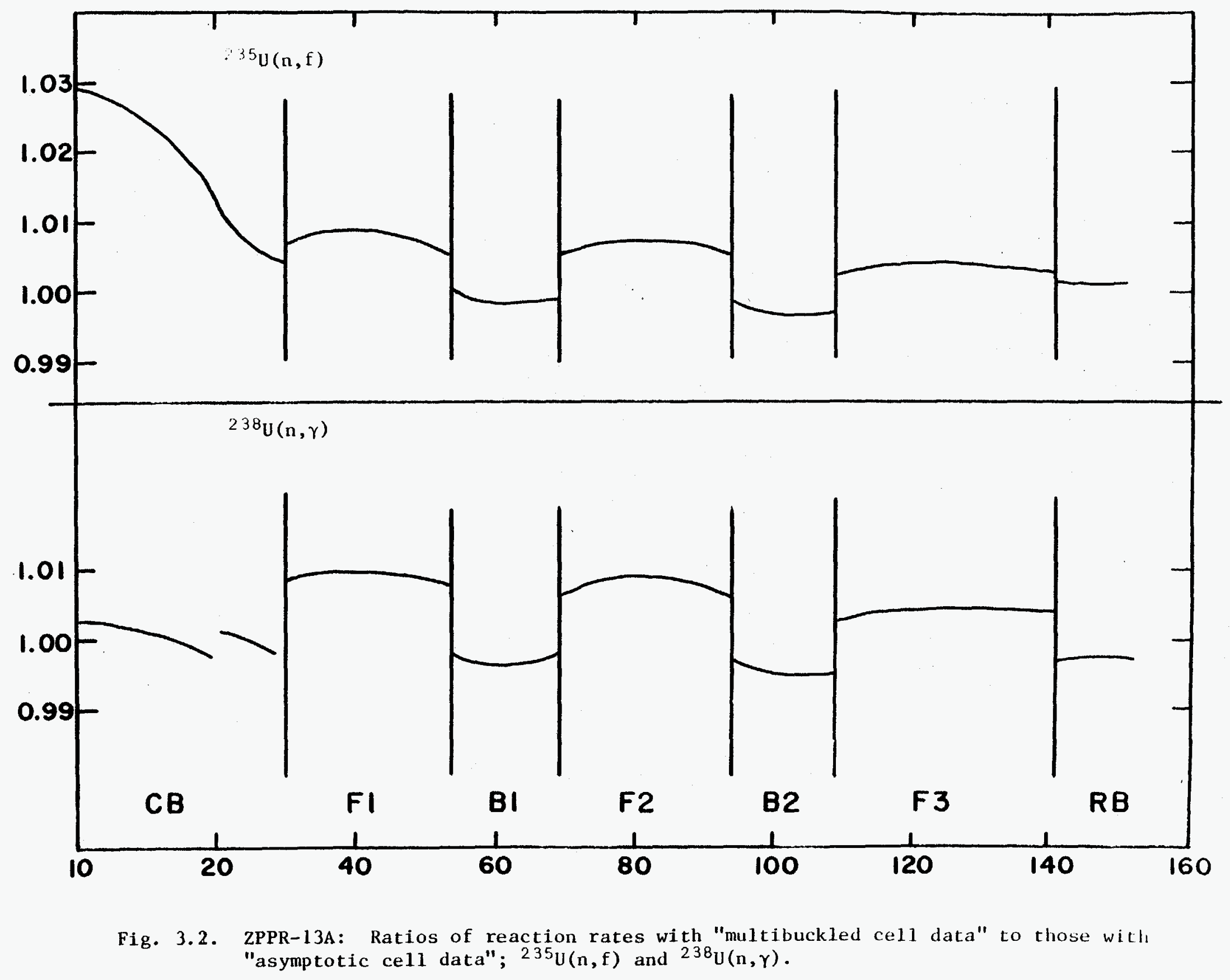




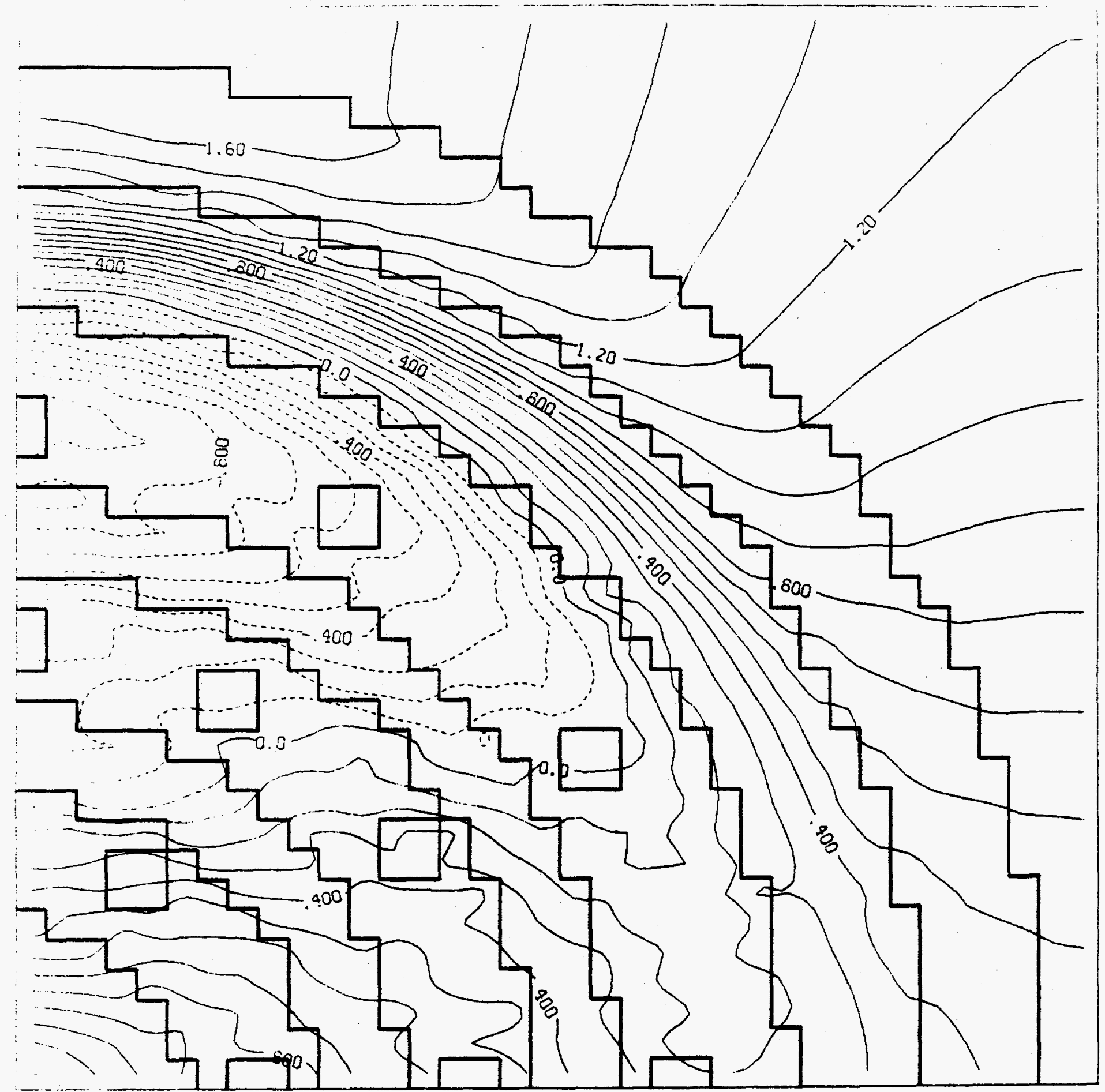

CONTIUR FROM -1.0 UDO TO 1.6000 CONTEUR INTFRVAL OF 0.10000

$\operatorname{PT}(3.3)=0.90599$

Fig. 3.3. Calculated percent change in ${ }^{235} \mathrm{U}$ f18810n rate in $2 P P R-13 A$ when plate streaming is included. 


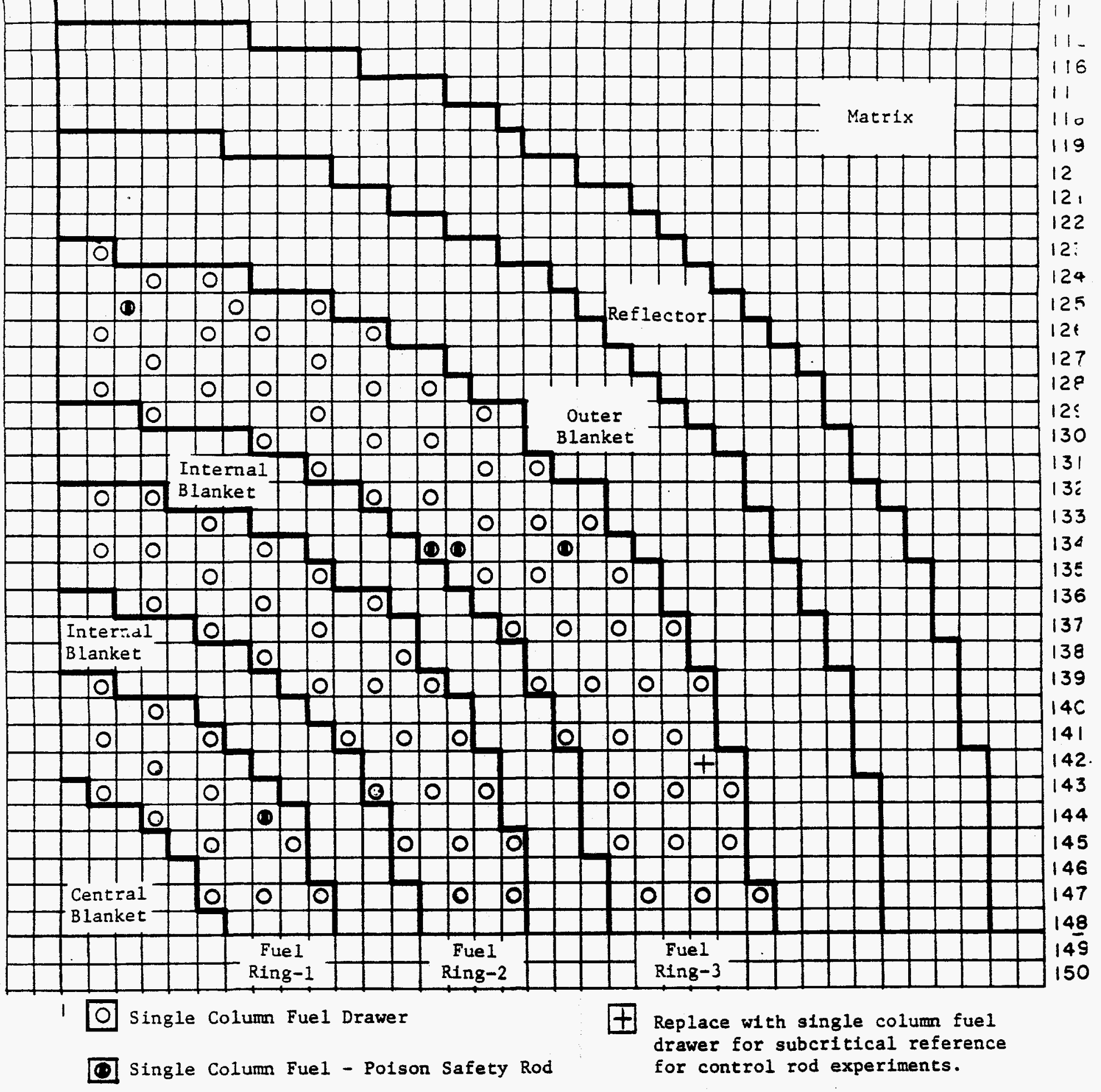




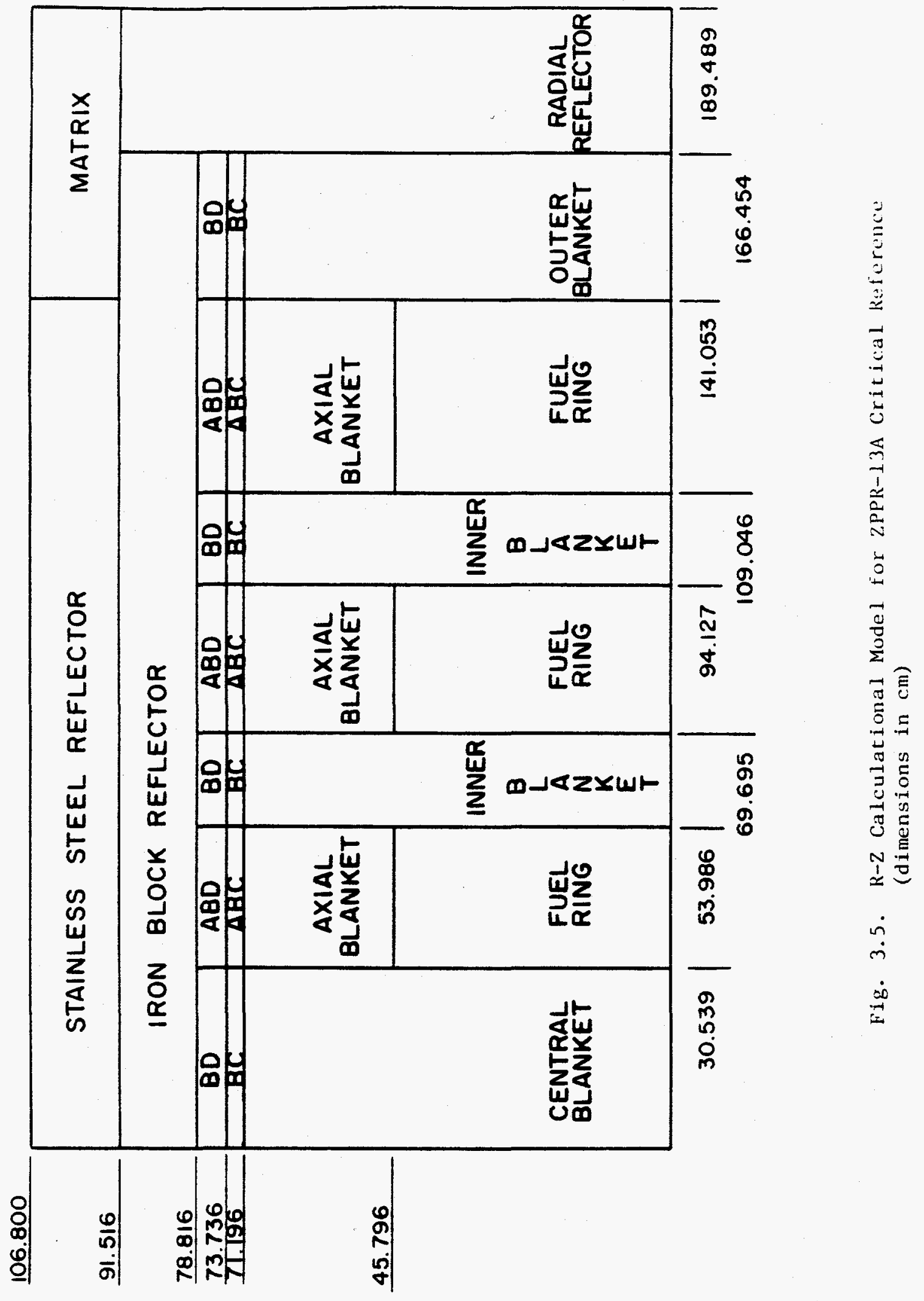




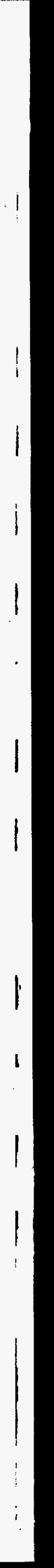





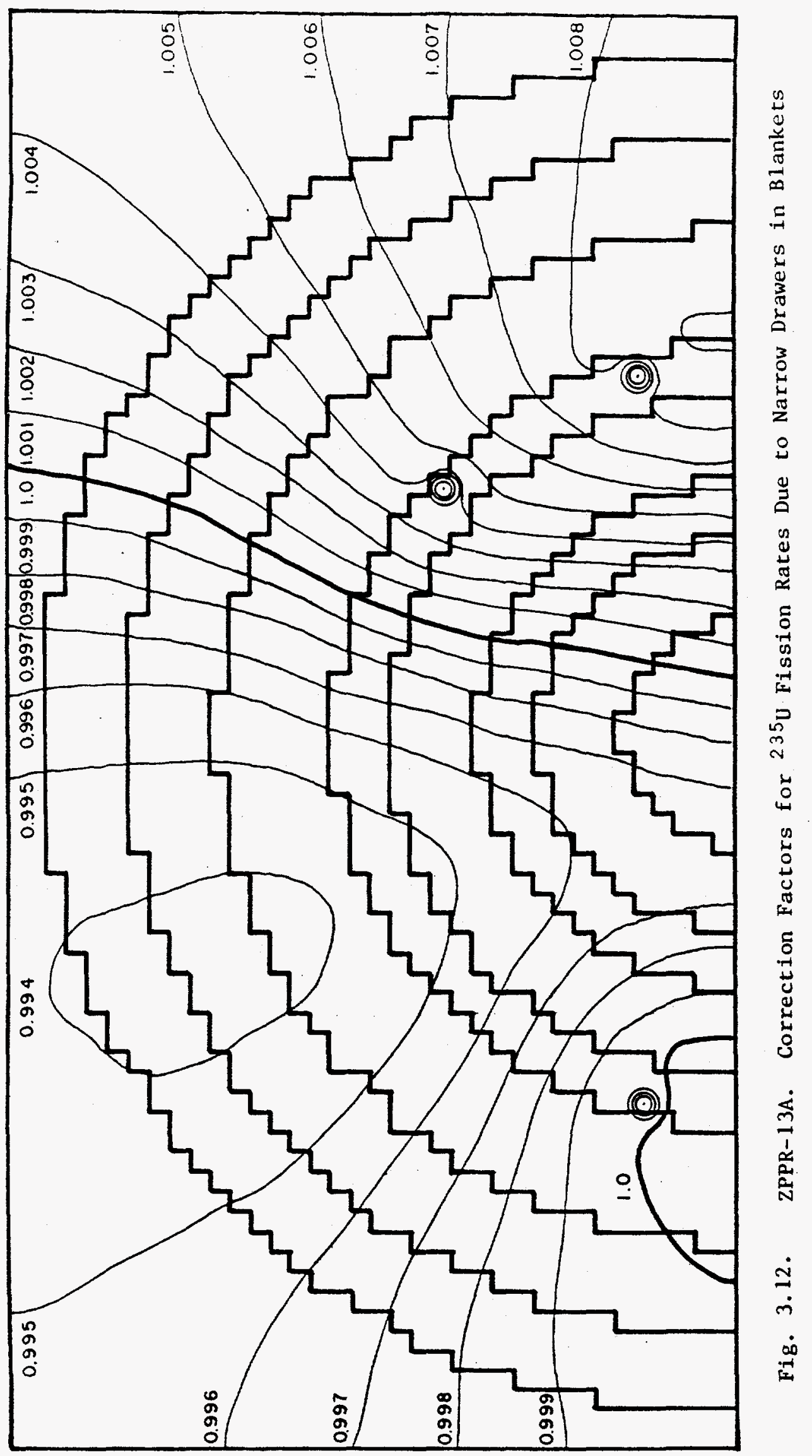




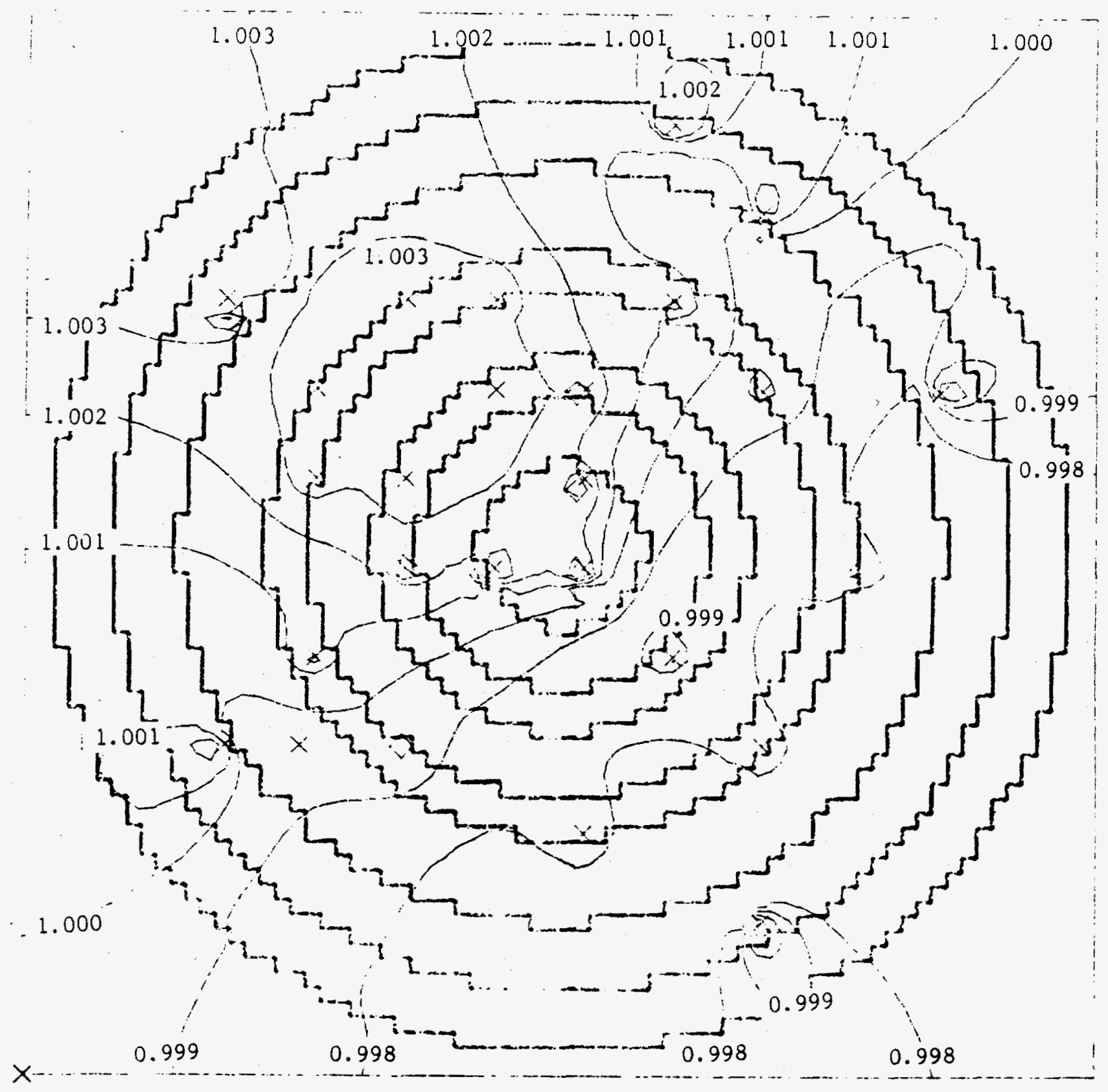

Fig. 3.13. Perturbation in $235 \mathrm{U}$ fission rates in $\mathrm{ZPPR}-13 \mathrm{~A}$ due to detector-drawers in blankets. 
$4849 \mid 505152535455565758596061626364656667686970717273747576777879808182838485$

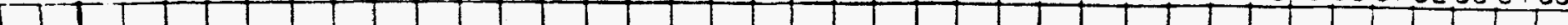

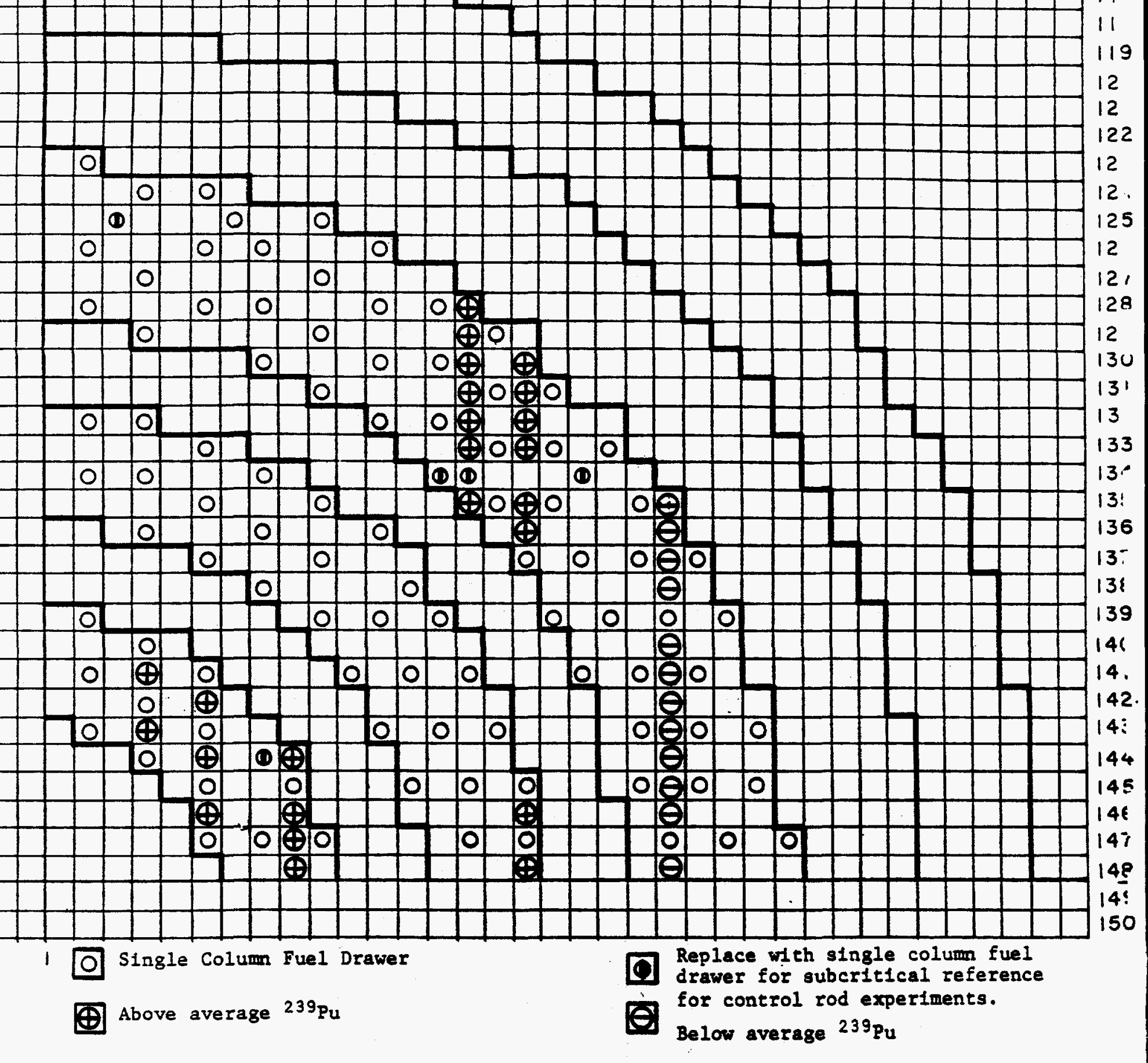


Fig. 3.15. Percent change in ${ }^{235}$ U fission rate in $2 \mathrm{PPR}-13 \mathrm{~A}$ using specific fuel drawer masters compared to homogenized mast:

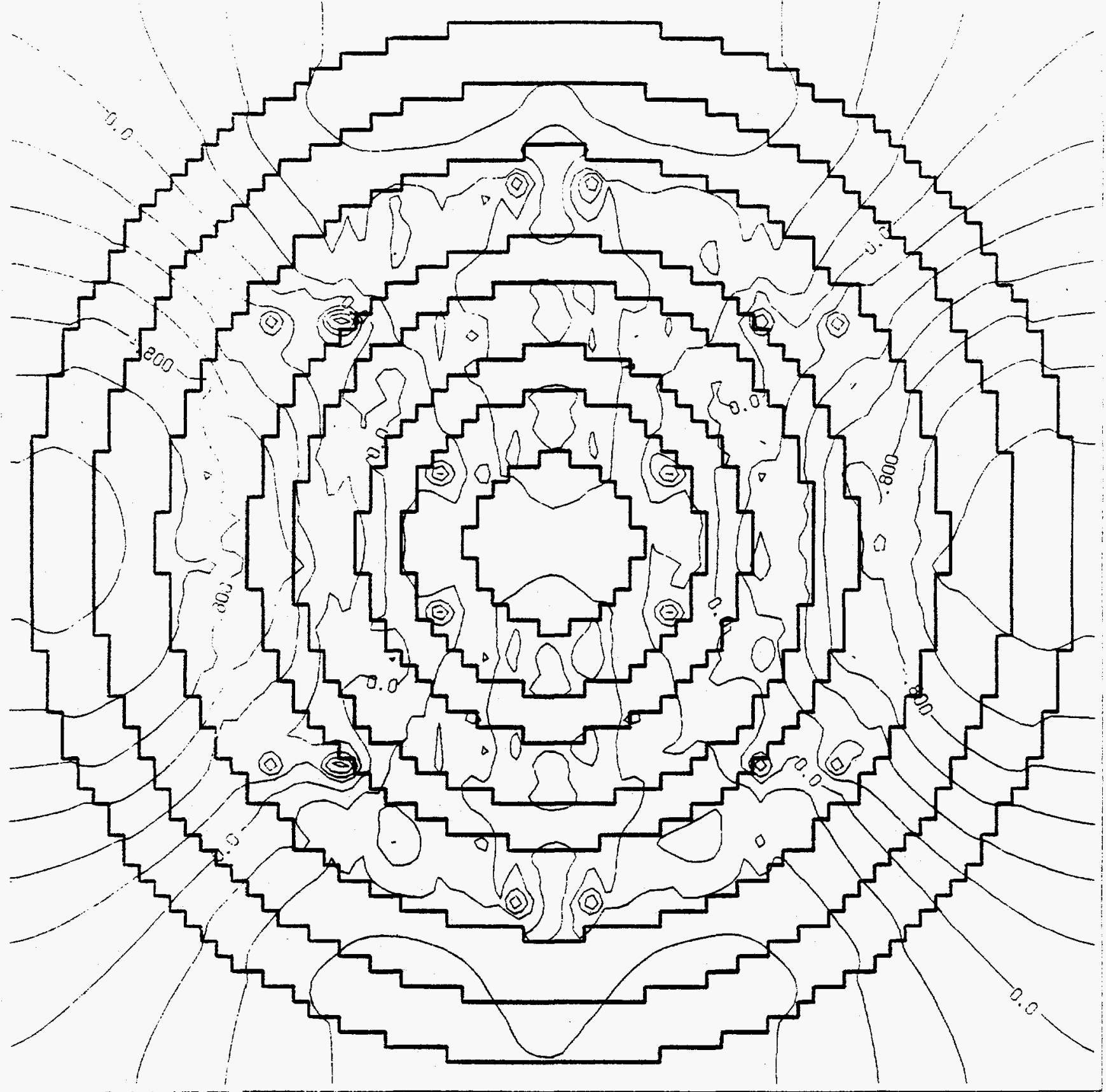

CQNTZUR FR̃M

CONTQUR INTERVAL OF 0.20000

$P T(3.3)=0.28932 F-01$ 
Fig. 3.16. Percent change in 235 U fission rate in ZPPR-13A using spectf1c blanket drawer masters compared to homogenized masters

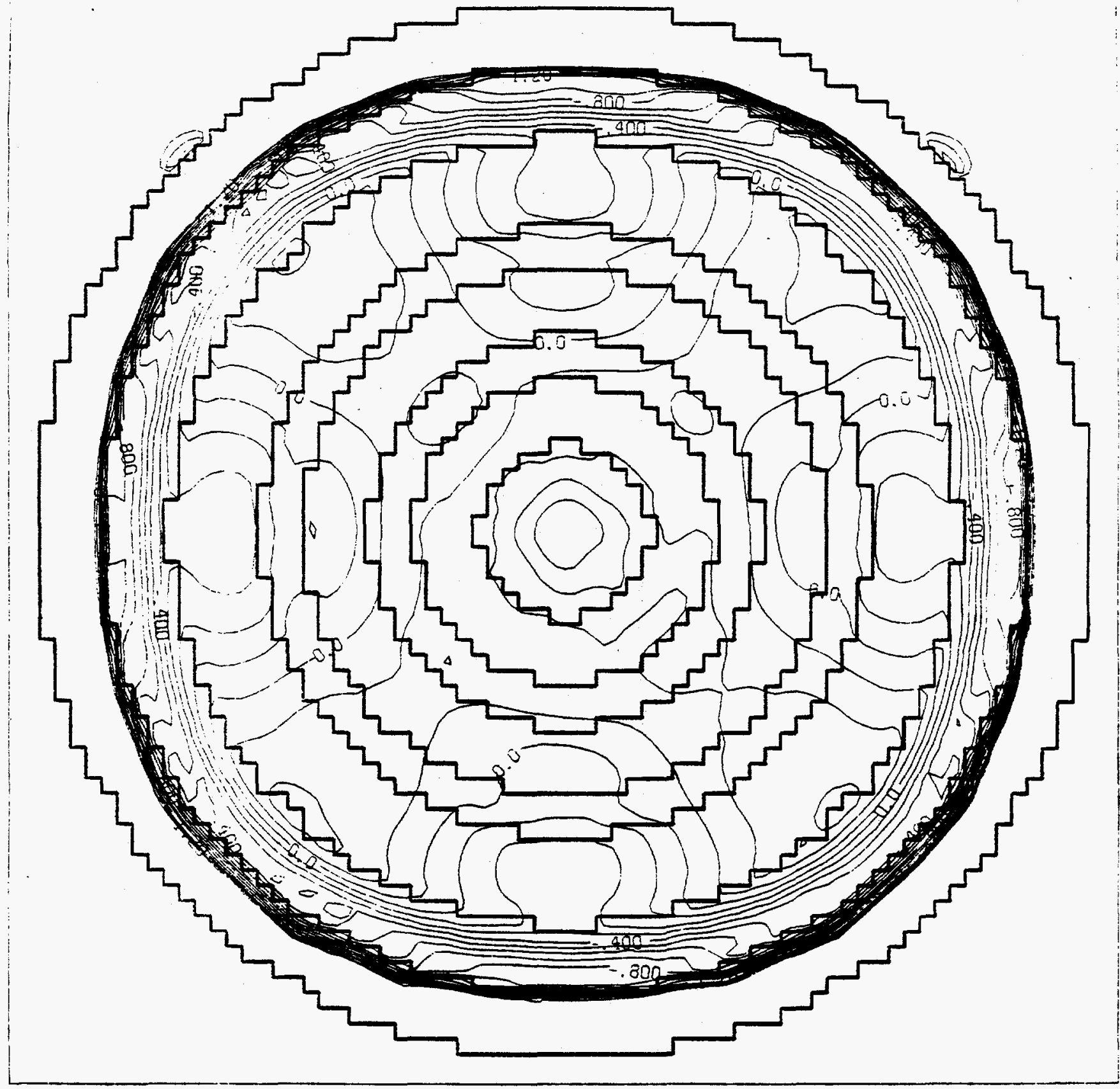

CONTOUR FFOM $-i .5000$ TO 1.4000 CONTQUR INTERVAL GF $0.10000 \quad$ PT $(3,3)=-2.2010$ 
Fig. 3.17. Percent silinge in 235 fission rate in ZPPR-13A wsing all-master model compared to homogeneous model.

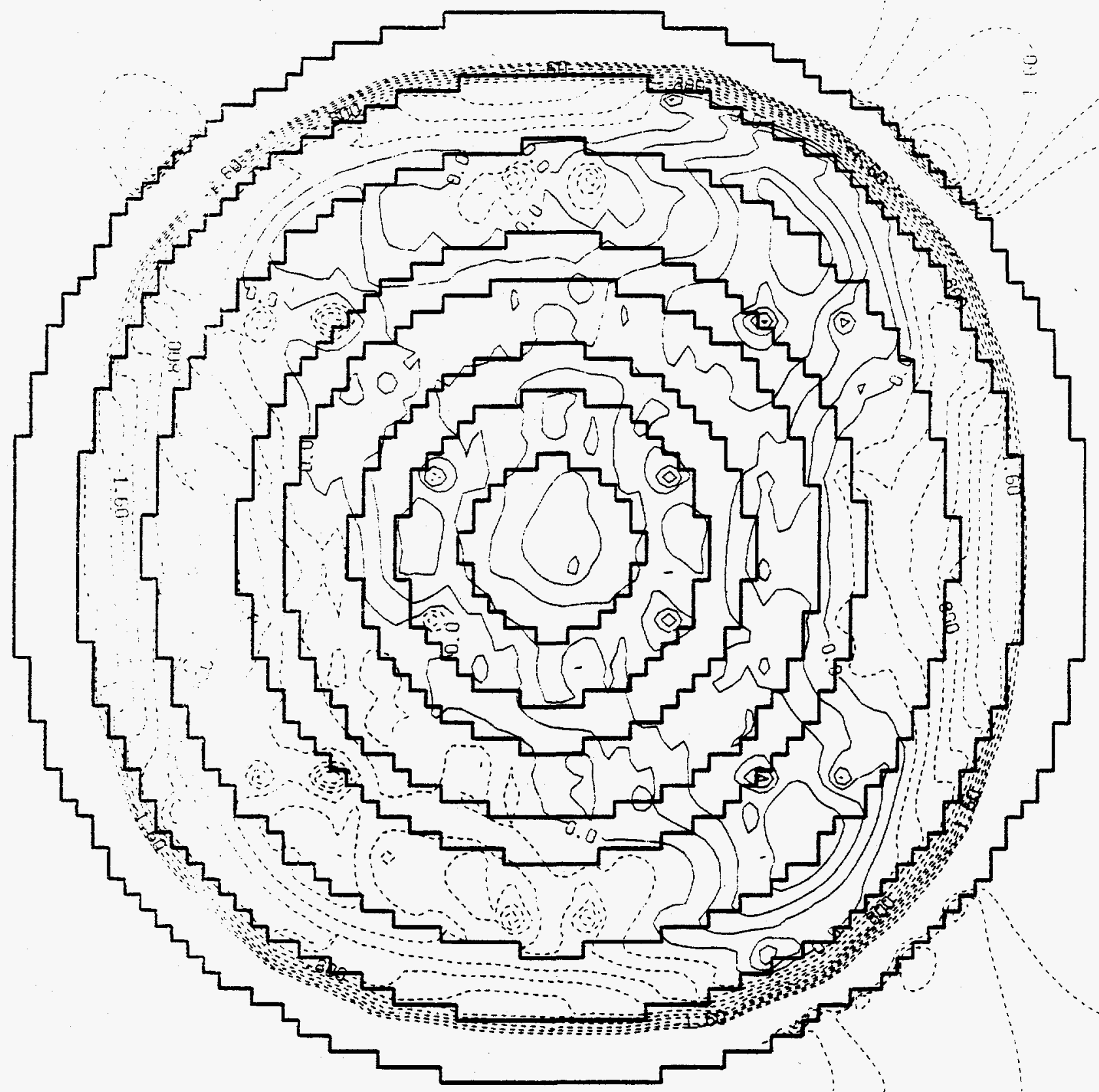

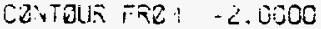

TR 2.0000

CONTOLR INTFRVAL OF 0.20000

$\operatorname{OT}(3.3)=-2.6320$ 
TABLE 3.1. Directional Diffusion Coefficient Modifiers for ZPPR-13A: D(Benoist)/D(Heterogeneous) a

\begin{tabular}{|c|c|c|c|c|c|c|c|c|c|c|c|c|c|c|}
\hline \multirow{2}{*}{ Group } & \multicolumn{2}{|c|}{$\begin{array}{c}\text { Double Column } \\
\text { Fuel }\end{array}$} & \multicolumn{2}{|c|}{$\begin{array}{c}\text { Single Column } \\
\text { Fue } 1\end{array}$} & \multicolumn{2}{|c|}{$\begin{array}{l}\text { Radial } \\
\text { Bl anket }\end{array}$} & \multicolumn{2}{|c|}{$\begin{array}{c}\text { Axial } \\
\text { Bl anket }\end{array}$} & \multicolumn{2}{|c|}{$\begin{array}{c}\text { Vo ided } \\
\text { Double Column } \\
\text { Fuel }\end{array}$} & \multicolumn{2}{|c|}{$\begin{array}{c}\text { Voided } \\
\text { Single col umn } \\
\text { Fuel }\end{array}$} & \multicolumn{2}{|c|}{$\begin{array}{l}\text { Voided } \\
\text { Radial } \\
\text { Blanket }\end{array}$} \\
\hline & 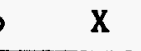 & $\mathrm{Y}, \mathrm{Z}$ & $\mathrm{X}$ & $\mathrm{Y}, \mathrm{Z}$ & $X$ & $Y, Z$ & $\mathbf{X}$ & $\mathrm{Y}, \mathrm{Z}$ & $\mathbf{X}$ & $\mathrm{Y}, \mathrm{Z}$ & $\mathrm{X}$ & $Y, Z$ & $X$ & $Y, Z$ \\
\hline 1 & 1.0178 & 1.0305 & 1.0212 & 1.0376 & .0028 & 1.0090 & 1.0133 & 1.0330 & 1.0193 & 1.0486 & 1.0208 & 1.0636 & 1.0021 & 1.0156 \\
\hline 2 & 1.0161 & 1.0307 & 1.0193 & 1.0384 & 1.0018 & 1.0087 & 1.008 & 1.0326 & 1.0182 & 1.0506 & 1.0195 & 1.0683 & 1.0014 & 1.0165 \\
\hline 3 & 1.0110 & 1.0262 & 1.0139 & 1.0327 & 1.0015 & 1.0083 & 1.0078 & 1.0293 & 1.0118 & 1.0470 & 1.0137 & 1.0650 & & 1.0167 \\
\hline 4 & 1.0069 & 1.0255 & 1.0081 & 1.0309 & 1.0004 & 1.0093 & 1.0049 & 1.0306 & 1.0087 & 1.0516 & 1.0100 & 1.0735 & 04 & 1.0214 \\
\hline 5 & 1.0063 & 1.0311 & 1.0064 & 1.0338 & 1.0008 & 1.0157 & 1.0066 & & 1.0066 & 1.0717 & 1.0066 & 1.09 & 99 & 1.0372 \\
\hline 6 & 1.0030 & 1.0161 & 1.0031 & 1.0157 & 1.0007 & 1.0069 & 1.0036 & 1.0196 & 1.0041 & 1.0622 & 1.0045 & 47 & & 1.0303 \\
\hline 7 & 1.0042 & & 1.0045 & 1.0516 & 1.0011 & & 1.0055 & & & 1.0992 & 1.0076 & 1.13 & 20 & 1.0570 \\
\hline 8 & 1.0034 & 1.0343 & 1.0035 & 1.0378 & 1.0016 & 1.0178 & 1.0047 & 1.0444 & 0066 & 1.0891 & 075 & & & 1.0465 \\
\hline 9 & 1.0035 & 1.0440 & 1.0040 & 1.0478 & 016 & 224 & & & & 1.0983 & 074 & 1.13 & 28 & 1.0495 \\
\hline 10 & & & & & & & & & & & & & & \\
\hline 11 & 1.0043 & 1.0441 & 1.0 & 1.0489 & 1.0020 & 1.0205 & 1.0077 & 1.0598 & 1.0081 & 1.1061 & 1.0108 & 1.1461 & 1.0039 & 1.0509 \\
\hline 12 & 1.0054 & & & 1.0706 & & 240 & & & & 1.1029 & 133 & 1.1486 & & 1.0435 \\
\hline 13 & 1.0027 & 1.0482 & 1.0 & 1.0525 & 1.0021 & 1.0244 & 1.0062 & 1.0631 & 1.0068 & 1.1098 & 1.0102 & 1.1474 & 1.0045 & 1.0531 \\
\hline 14 & 1.0029 & & 1.0 & & & & & & & 1.09 & 125 & 1.1432 & 44 & 1.0466 \\
\hline 15 & 1.0035 & 1.0365 & 1.0142 & 1.0700 & 1.0049 & 1.0257 & 1.0143 & 1.0702 & 1.0076 & 1.0836 & 1.0252 & 1.1609 & 80 & 1.0467 \\
\hline 16 & 1.0032 & 1.0108 & 1.0054 & 1.0160 & 1.0027 & 1.0121 & 1.0094 & & 1.0061 & 1.0829 & 209 & 1.1534 & 75 & 1.0469 \\
\hline 17 & 1.0168 & 1.0352 & 1.0213 & 1.0532 & 1.0401 & 1.1063 & 1.0182 & 1.0497 & 1.0060 & 1.0923 & 1.0209 & 1.1635 & 34 & 1.0498 \\
\hline 18 & 0.9955 & 1.0347 & 0.9999 & 1.0472 & 1.0001 & 1.0161 & 1.0030 & 1515 & 1.0063 & 1.1070 & 161 & 1.1640 & 0060 & 1.0478 \\
\hline 19 & 1.0001 & 1.0625 & 1.0076 & 1.0891 & 1.0033 & 1.0274 & 1.0114 & 1.09 & & 1.1082 & 0161 & 1.1664 & 60 & 1.0462 \\
\hline 20 & 1.0000 & 1.0692 & 1.0080 & 1.0969 & 1.0038 & 1.0275 & 1.0131 & 1.0935 & 1.0038 & 1.1110 & 1.0143 & 1.1668 & 1.0058 & 1.0437 \\
\hline 21 & 1.0006 & & 1.0151 & 1.1093 & 1.0064 & 1.0349 & 1.0178 & 1.1003 & 1.0041 & 1.0896 & 1.0224 & 1.16 & & 1.0468 \\
\hline 22 & 0.9956 & 1.0871 & 1.0072 & 1.1169 & 1.0050 & 1.0337 & 1.0183 & 1.1151 & 0.9999 & 1.1303 & 1.0141 & 1.1878 & 1.0071 & 1.0495 \\
\hline 23 & 0.9934 & & 1.0044 & 1.1129 & 1.0044 & 1.0290 & 1.0151 & 1.1015 & 0.9977 & 1.1294 & 1.0107 & 1.1826 & 1.0063 & 1.0438 \\
\hline 24 & 0.9857 & 1.0909 & 0.9979 & 1.1154 & 1.0041 & 1.0282 & 1.0134 & 1.0981 & 0.9918 & 1.1362 & 1.0050 & 1.1861 & 1.0065 & 1.0436 \\
\hline 25 & 0.9820 & & 0.9934 & 1.1233 & 1.0039 & 1.0270 & 1.0137 & 1.0942 & 0.9895 & 1.1517 & 0.9996 & 1.1949 & 1.0057 & 1.0414 \\
\hline 26 & 0.9998 & 1.0871 & 1.0097 & 1.1174 & 1.0047 & 1.0378 & 1.0172 & 1.1332 & 1.0068 & 1.1345 & 1.0178 & 1.1930 & 1.0078 & 1.0577 \\
\hline 27 & 0.9497 & & & & 1.0046 & & & & & 1.2112 & 0.9856 & 1.2350 & & 1.0534 \\
\hline 28 & 1.0029 & 1.0806 & 0.9959 & 1.1139 & 1.0037 & 1.0262 & 1.0136 & 1.0926 & 1.0059 & 1.1284 & 1.0034 & 1.1895 & 1.0055 & 1.0412 \\
\hline
\end{tabular}

a In ZPPR, the $x$-direction is perpendicular to the plates in the unit cells. The y- and $z$-directions are parallel

to the plates and are equivalent in the models used to represent the ZPPR cells.

File MR 3/B 3, 4 
TABLE 3.2 . Energy Structure of the Cross Section Sets used for 2PPR-13 Analys is

Energy Boundary 8-Group Number 28-Group Number 226-Group Number $\quad$ 2082-Group Number

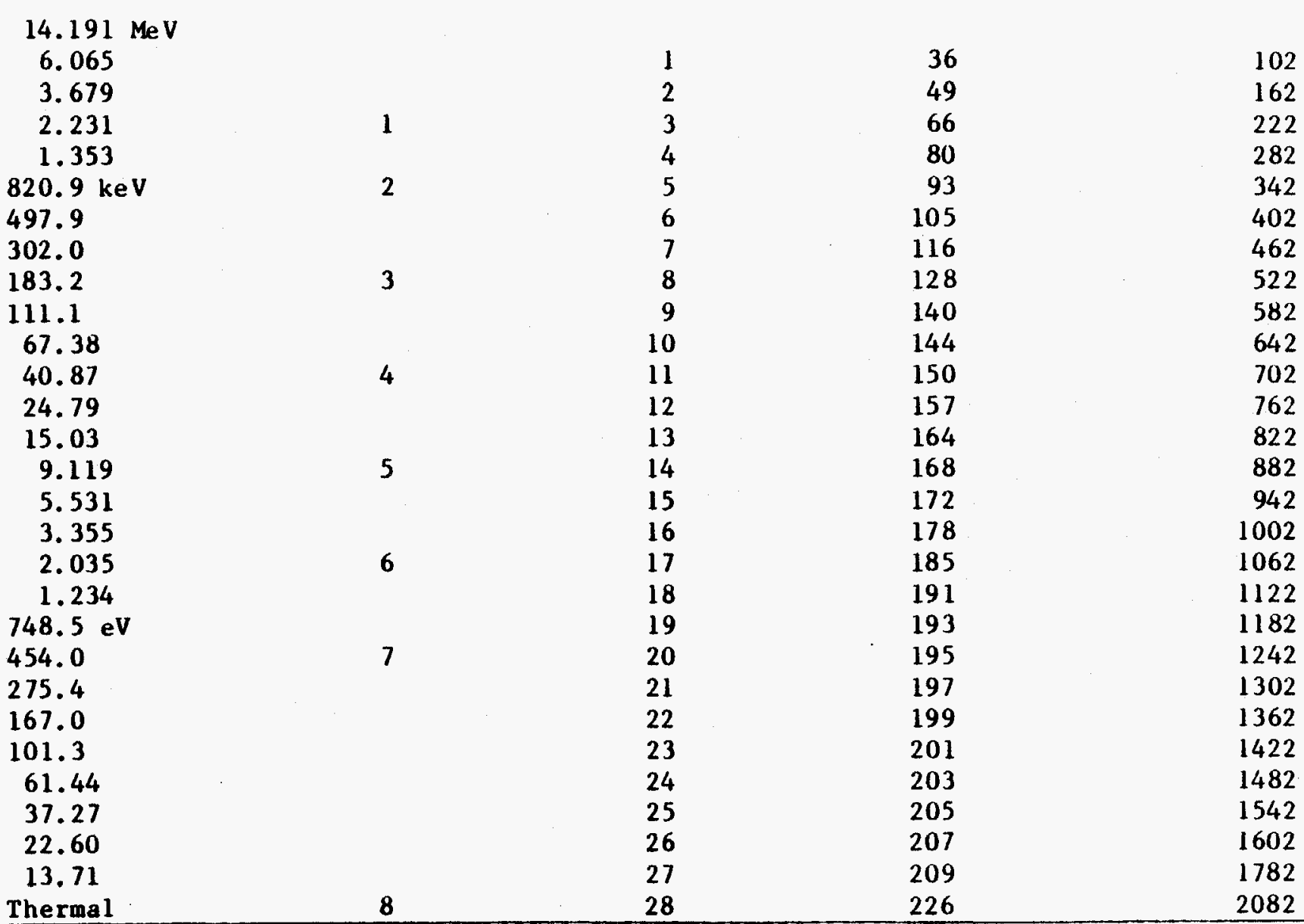

a The MC ${ }^{2}-\mathrm{I}$ I library used 2082 groups with a lethargy width of $1 / 120$. The SDX intermediate 1 ibrary had 226 groups with a variable lethargy width. JAII $2 B 14$ 
TABLE 3.3. Variation in Average Composition of Drawer Masters in $\mathrm{ZPPR}-13 \mathrm{~A}$

\begin{tabular}{|c|c|c|c|c|c|c|c|}
\hline \multirow[t]{2}{*}{ Master } & \multirow[t]{2}{*}{ Type } & \multirow[t]{2}{*}{ Number ${ }^{a}$} & \multicolumn{2}{|c|}{$\begin{array}{c}\text { Deviation in Mass } \\
\text { from Average, } \%\end{array}$} & \multicolumn{3}{|c|}{ Character b } \\
\hline & & & $239^{\mathrm{Pu}}$ & $238_{U}$ & & & \\
\hline 101 & SCF & $179 / 181$ & +0.07 & +0.05 & & V63 & $8-4-6$ \\
\hline 102 & $S C E$ & $178 / 182$ & +0.01 & -0.00 & & V63 & $7-5-6$ \\
\hline 103 & SCE & $16 / 16$ & +0.24 & +0.02 & & V63 & $5-5-8$ \\
\hline 701 & SCF & $3 / 1$ & +0.07 & +0.05 & FC & v63 & $8-4-6$ \\
\hline 705 & SCF & $6 / 2$ & +0.01 & -0.00 & FC & V63 & $7-5-6$ \\
\hline $801(802)$ & SCF & $18 / 18$ & $-1.02 *$ & -0.52 & PSR & V63 & $5-5-4-4$ \\
\hline 201 & DCF & $111 / 111$ & -0.08 & +0.07 & & V65 & $7-5-6$ \\
\hline 202 & DCF & $172 / 168$ & +0.07 & +0.18 & & V65 & $5-5-8$ \\
\hline 203 & DCF & $250 / 252$ & -0.00 & +0.13 & & V65 & $8-4-6$ \\
\hline 207 & DCF & $59 / 59$ & $+0.92 *$ & -0.33 & & V63 & $5-5-8$ \\
\hline 208 & DCF & $40 / 40$ & $+0.67 *$ & -0.47 & & V63 & $7-7-4$ \\
\hline 209 & DCF & $40 / 40$ & $-1.18 *$ & -1.08 & & V65 & $5-5-4-4$ \\
\hline 210 & DCE & $31 / 30$ & -0.05 & +0.10 & & V65 & $6-6-6$ \\
\hline 211 & DCF & $86 / 85$ & +0.07 & +0.18 & & v65 & $5-5-8$ \\
\hline 212 & DCF & $175 / 174$ & -0.20 & -0.01 & & V65 & $7-7-4$ \\
\hline 213 & $D C F$ & $.56 / 56$ & -0.08 & +0.07 & & V65 & $7-5-6$ \\
\hline 218 & $\mathrm{DCF}$ & $8 / 8$ & $-0.35 *$ & -1.58 & & V63 & $5-5-4-4$ \\
\hline 702 & DCF & $1 / 1$ & -0.08 & +0.07 & FC & V65 & $7-5-6$ \\
\hline 706 & $D C F$ & $1 / 1$ & $+0.92 *$ & -0.33 & FC & V63 & $5-5-8$ \\
\hline 707 & DCF & $1 / 2$ & -0.05 & +0.10 & FC & $v 65$ & $8-6-6$ \\
\hline 708 & DCF & $2 / 7$ & +0.07 & +0.18 & FC & V65 & $5-5-8$ \\
\hline 709 & $D C F$ & $6 / 4$ & -0.00 & +0.13 & FC & V65 & $8-4-6$ \\
\hline 711 & DCF & $1 / 1$ & $-0.60 *$ & -0.49 & $T C$ & V65 & $7-7-4$ \\
\hline 712 & $D C F$ & $0 / 1$ & -0.20 & -0.01 & & v65 & $7-7-4$ \\
\hline 501 & $I B / R B$ & $275 / 274$ & - & +1.02 & RB & inne & $r \operatorname{IB} 2(x)$ \\
\hline 502 & IB & $72 / 71$ & -- & +1.03 & $\mathrm{CB}$ & edge & $45^{\circ}$ \\
\hline 503 & $\mathrm{RB}$ & $278 / 280$ & -- & +0.91 & Mid & ddle & of $R B$ \\
\hline 504 & & $75 / 74$ & -- & +1.02 & IB & $(y)$ & \\
\hline 505 & IB & $172 / 169$ & -- & -0.63 & B2 & $45^{\circ}$ & \\
\hline 506 & IB & $150 / 150$ & $\rightarrow$ & -.0 .63 & $B 1 x$ & $x$ and & $y$ \\
\hline 507 & IB & $70 / 71$ & -- & -0.63 & $C B C E$ & enter & $\&$ axes \\
\hline 508 & $R B$ & $167 / 168$ & -- & -0.63 & $\mathrm{RB}$ & outer & zone \\
\hline 509 & RB & $72 / 72$ & - & -0.63 & RB 0 & out si & ide \\
\hline 510 & RB & $16 / 16$ & -- & -0.63 & $\mathrm{RB}$ & out si & \\
\hline 511 & RB & $47 / 48$ & -- & -0.63 & RB 0 & outsi & \\
\hline 703 & IB / RB & $12 / 13$ & -- & -7.71 & FC & $d$ istr & ibuted \\
\hline $803(804)$ & IB & $6 / 16$ & -- & -25.72 & PSR & & \\
\hline
\end{tabular}

${ }^{2}$ Number in hal $\mathrm{f}-1$ and hal $\mathrm{f}-2$.

bV63 $_{\text {V }}$ Vendor 63 fue $1, V 65=$ Vendor 65 fuel, $F C=F$ ission chamber drawer, PSR = Narrow drawer for PSR, TC = thermocouple drawer. $a-b-c=$ fuel piece distribution $a$ in., $b$ in., $c$ in. from midplane. *Major deviation in ${ }^{239} \mathrm{Pu}$. JAIIA 15 
TABLE 3.4. Perturbation in Control Rod Worths in 2PPR-13A due to Variations in Master Loadings

\begin{tabular}{|c|c|c|c|c|}
\hline $\begin{array}{l}\text { Control } \\
\text { Rods } \\
\end{array}$ & $\begin{array}{l}\text { Worth by } \\
\text { AMM Model, } \$ a \\
\end{array}$ & $\begin{array}{r}\text { Worth by } \\
\text { Homogeneous Model, } \$ \\
\end{array}$ & $\begin{array}{c}\text { Ratio } \\
\text { (Correction) } \\
\end{array}$ & $\begin{array}{c}\text { Estimated } \\
\text { Correction } \\
\text { from Fission Rates }{ }^{b} \\
\end{array}$ \\
\hline CR22 & 0.7406 & 0.7458 & 0.993 & 0.995 \\
\hline CR25 & 0.8537 & 0.8708 & 0.980 & 0.981 \\
\hline CR28 & 0.7466 & 0.7458 & 1.001 & 1.000 \\
\hline CR31 & 0.8462 & 0.8708 & 0.992 & 0.990 \\
\hline $6 R 3$ & 7.363 & 7.385 & 0.997 & 0.997 \\
\hline
\end{tabular}

aCalculations $28 G$ XY IMPD WBD, $B=0.3294 \%$.

${ }^{b}$ Square of $235 \mathrm{U}$ fission rate ratio in AMM to HMM.

JAII非 $2 A 7$

TABLE 3.5. Characterization of the Eigenvalue Spectrum in ZPPR-13 Series of As semblies

\begin{tabular}{lc}
\multicolumn{2}{c}{ Series of As semblies } \\
$\begin{array}{l}\text { Assembly } \\
13 \mathrm{~A}\end{array} \frac{\begin{array}{c}\text { Separat ion Between } \\
\mathrm{k} \cup \text { and } \mathrm{k}_{1} \mathrm{a}\end{array}}{2.66}$
\end{tabular}

$a_{k_{e} f f}$ of the fundamental mode
solution $\left(k_{0}\right)$ and the first
azimuthal harmonic solution $\left(k_{1}\right)$. 
TABLE 3.7 . E igenvalue Separation for 2PPR-13 Core

\begin{tabular}{|c|c|c|c|c|c|}
\hline \multirow[b]{2}{*}{ Assembly } & \multirow{2}{*}{$\begin{array}{c}\text { Zero Flux } \\
\text { Axis }\end{array}$} & \multirow{2}{*}{$\begin{array}{c}\text { Subcritical } \\
\text { Reference }\end{array}$} & \multicolumn{3}{|c|}{ Control Rod Banks ${ }^{a}$} \\
\hline & & & $F 1$ & $E 2$ & F3 \\
\hline$Z P P R-13 A$ & $\begin{array}{c}y \\
x \\
x+y\end{array}$ & $\begin{array}{l}0.0266 \\
0.0293 \\
0.0808\end{array}$ & $\begin{array}{l}0.0175 \\
0.0205 \\
0.0653\end{array}$ & $\begin{array}{l}0.0147 \\
0.019 \\
0.0528\end{array}$ & $\begin{array}{l}0.0396 \\
0.0254 \\
0.1041\end{array}$ \\
\hline
\end{tabular}

a Calculated for subcritical cores. The banks contained six control rods in Fl, $t$ welve in $F 2$ and twelve in F3 
TABLE 3.8 . Sensitivity of Fission Rates in ZPPR-13A

Percent Change in Fission Rate for $5 \%$ Increase in $238 \mathrm{U}$ Capture ${ }^{2}$

\section{Zone} ZPPR $-13 A$

$y$-axis Zone Average

F1 -1.2

$-1.2$

F2 -0.5

$-0.4$

E3

$+0.4$

$+0.5$

${ }^{a}$ Calculations for design models, not the final configurations, normalized to same total power. 


\subsection{CRITICALITY PREDICTIONS, BETA, REACTIVITY COEFEICIENTS}

\subsection{Analysis of k-effective}

The experimental values for $k_{e f f}$, after adjustment to a core with all shim and safety rods removed and to a temperature of $293 \mathrm{~K}$, are $\mathrm{g}$ iven in Table 4.1. The estimated uncertainties (Table 2.1) are about $0.04 \% \Delta \mathrm{k}$, but several of the larger components are correlated among the assemblies.

The results of the diffusion theory calculations are given in

Table 4.2. Several small corrections are applied to the reference results. The correction of $-0.032 \% \Delta k$, for streaming in the airgap above the plates in each drawer, was estimated for ZPPR-8 and has been used for all subsequent cores. Corrections for $239 \mathrm{Pu}, 240 \mathrm{Pu}, 241 \mathrm{Pu}$ and $238 \mathrm{~J}$ load ings were derived by comparing the isotopic masses edited from the xyz model with those from the $Z P P R$ fuel inventory system. The small differences in mass were converted to $\Delta k$ us ing atom-density sensitivity coefficients calculated for ZPPR-13A (Section 4.3). The correction for $241 \mathrm{Pu}$ is shown separately since this is mainly due to having a fixed date for decay calculation in the cross section library.

The diffusion theory $C / E$ results are similar for all phases and span a range of 0.976 to 0.979 .

A number of transport calculations have been made for $2 P P R-13 A$ in $x y, r z$ and $r$ geometry. These used a fine mesh, equivalent to $27 \mathrm{~mm}$ in the $x y$ plane (or four meshes per drawer). Axial buckling terms for xy models were derived from the reference xyz solution and buckling terms for $r$ models were 
derived from an $r z$ solution. Two-dimensional models'were calculated with. $s_{4}$ angular quadrature and one-dimensional models used, in addition, $s_{16}$ quadrature with a finer mesh (equivalent to nine meshes per drawer). The mesh and transport corrections are given in Table 4.3.

The est imated transport correction for $2 P P R-13 A$ is relatively large in comparison with that for conventional cores. The $x y$ and $r$ models show that this results principally from the annular geometry. The results in the two geometries differ by $0.2 \%$. The transport option of the DIF 3D code was used for xy geometry and the ONEDANT code was used for $r$ geometry. It is not clear at this stage that this difference is due wholly to the better geometric representation in the $x y$ model. Effects due to insufficiently refined mesh size and angular quadrature, and in the application of the buckling terms, may be different in the two geometries and codes. The effects of finer mesh in the $r$ dimension and of higher order quadrature in the transport calculations are fairly small. Using the rz transport correction with the available mesh and angular refinements, the correction to the reference $x y z$ diffusion solution is estimated to be $+0.76 \% \Delta_{k}$. The corrected $C / E$ value for $2 P P R-13 A$ is then 0.9857 .

Table 4.4 compares the $k_{e}$ ff results for a number of $2 P P R$ cores. Diffusion calculations for the heterogeneous cores with no plutonium in the blankets ( $B O C$ cores) are about $0.5 \% \Delta_{k}$ lower than for the EOC-cores or the conventional cores. After transport corrections are applied, the results for all cores fall in the range 0.984 to 0.987 . The corrected result for $2 P P R-13 A$, 0.986 is in good ag reement.

\section{2 Delayed Neutron Parameters}

Delayed neutron parameters for $2 P P R-13$ were calculated with the ENDF/B-V delayed neutron data (with reactor fluxes calculated using ENDF/B-IV 
cruss sections;. The original calculations used reactor models in rz geonetry. The calculations were repeated using the three-dimensional models in $x y z$ geometry using the VARI3D editor. Parameters from both models are shown in Table 4.5.

For $2 P P R-13 A$, the Beff values from $r z$ and $x y z$ models are in close agreement as would be expected from the cylindrical design of the core.

\section{3 Reactivity Coefficients}

Reactivity coefficients for the most important heavy isotopes were calculated for $Z P P R-13 A$ using the $r z$ model. The reactivities were calculated for a $1 \%$ increase in density in each region of the core (mass or number-density sensitivity coefficients). These are shown in Table 4.6. The results have been used to make small corrections to $k_{e} f f$ for differences in masses between the calculations and the actual loadings. 
TABLE 4.1. Experimental Values for $k_{e f f}$ in the $2 P P R-13$ Reference Core

\begin{tabular}{|c|c|c|c|c|}
\hline As semb ly & $\begin{array}{c}\text { Measured } \\
\text { Excess, } \\
\% \delta k\end{array}$ & $\begin{array}{c}\text { Temperature } \\
\text { Correction to } 293 \mathrm{~K}, \\
\% \delta \mathrm{k}\end{array}$ & $\begin{array}{l}\text { PSR } \\
\text { Correctiona } \\
\% \delta k\end{array}$ & $\begin{array}{c}\text { Corrected } \\
\text { keff }\end{array}$ \\
\hline $13 \mathrm{~A}$ & 0.0221 & 0.0238 & 0.0040 & 1.000499 \\
\hline
\end{tabular}

astimated correction for $B_{4} C$ poison safety blades which were fully withdrawn. 
TABLE 4.2.

Reference Calculations

\section{ZPPR-13A}

xyz 28 groups

0.97891

\section{Corrections}

Uniform axial mesha $\quad-0.00003$

Air gap streaming $\quad-0.00032$

$241 \mathrm{Pu}$ decay $\quad-0.00004$

Fuel loading $\quad+0.00007$

Corrected Calculation $\quad 0.97859$

$\begin{array}{ll}C / E & 0.9781\end{array}$

The xyz models used a variable axial mesh to accommodate the ZPPR shim rods. A correction is made to a uniform mesh of $51 \mathrm{~mm}$ in the core region. 
TABLE 4.3. Mesh and Transport Corrections Derived for $Z P P R-13 A$

\begin{tabular}{|c|c|c|}
\hline Correction & Source & Value, $\Delta k$ \\
\hline $\begin{array}{r}\text { Mesh in } x y-p l \text { ane } \\
55 \mathrm{~mm} \text { to } 27 \mathrm{~mm}\end{array}$ & $\begin{array}{l}\text { xy models } \\
r \text { models }\end{array}$ & $\begin{array}{l}-0.0016 \\
-0.0014\end{array}$ \\
\hline $\begin{array}{l}\text { Total transport: } \\
\text { diffusion to } \mathrm{S}_{4} \text { with mesh } \\
\text { equivalent to } 27 \mathrm{~mm}\end{array}$ & $\begin{array}{l}\text { rz diffusion } \\
\text { and } 54 \text { models }\end{array}$ & +0.0087 \\
\hline $\begin{array}{l}\text { Transport in } x y-p l a n e: \\
\text { diffusion to } \mathrm{s}_{4} \text { with mesh } \\
27 \mathrm{~mm} \text { or equivalent }\end{array}$ & $\begin{array}{r}\text { xy models } \\
r \text { models }\end{array}$ & $\begin{array}{l}+0.0073 \\
+0.0051\end{array}$ \\
\hline $\begin{array}{l}\mathrm{S}_{4} \text { to } \mathrm{S}_{16} \text { quadrature with } \\
\text { mesh equivalent to } 27 \mathrm{~mm}\end{array}$ & $r$ models & +0.0002 \\
\hline $\begin{array}{l}\text { Transport mesh in } x y-p l a n e: \\
-27 \text { mm to }-18 \mathrm{~mm} \text { with } \\
s_{16} \text { quadrature }\end{array}$ & $r$ models & +0.0003 \\
\hline
\end{tabular}




\begin{tabular}{|c|c|c|c|c|c|c|}
\hline \multirow[b]{2}{*}{ Physics Benchmarks } & \multicolumn{3}{|c|}{ Diffusion Theory $k_{e f f}$} & \multicolumn{3}{|c|}{ Transport Theory $k_{\text {eff }}$} \\
\hline & No. & Mean & S.D. & No. & Mean & S.D. \\
\hline ZPPR -2 & 1 & 0.9828 & --- & 1 & 0.9854 & -- \\
\hline ZPPR-9 & 1 & 0.9827 & -- & 1 & 0.9842 & --- \\
\hline ZPPR-7A & 1 & 0.9761 & --- & 1 & 0.9855 & -- \\
\hline $2 \mathrm{PPR}-13$ & 5 & 0.9777 & 0.0010 & $i$ & 0.9857 & --- \\
\hline
\end{tabular}

\section{Cores with CRPs}

$\begin{array}{lllllll}\text { Small conventional } & 3 & 0.9789 & 0.0007 & 3 & 0.9844 & 0.0007 \\ \text { Large conventional } & 3 & 0.9794 & 0.0007 & 3 & 0.9846 & 0.0011 \\ \text { Small heterogeneous } & \\ \quad & & & & & & \\ \quad \text { BOC } & 6 & 0.9751 & 0.0022 & 3 & 0.9868 & 0.0023 \\ \quad \text { EOC } & 4 & 0.9787 & 0.0008 & 2 & 0.9863 & -\ldots\end{array}$

aResults from 2PPR-7 and 2PPR-11. Beginning-of-cycle (BOC) cores have no plut onium in blanket regions. The end-of-cycle (EOC) cores simulated plutonium buildup. 
TABLF: 4.5. Candations of Beff and 2 for ZPPR-13

rz Calculation

xyz Calculation

Prompt Neutron

As sembly

Lifetine (l) $10^{-7} \mathrm{sec}$

Beff, \%

$\beta_{e f f}$

$2 P P R-13 A$

4.049

0.3296

0.3294

TABLE 4.6.

Mass Sensitivity Coeffic ients for ZPPR-13

Assembly Isotope Percent $\Delta k / k$ Per Percent Increase in Mass

$\begin{array}{ccc}2 P P R-13 \mathrm{~A} & 239 \mathrm{Pu} & 0.541 \\ & 24 \mathrm{UPu}^{\mathrm{Pu}} & 0.0110 \\ & 241 \mathrm{Pu} & 0.00780 \\ & 238 \mathrm{U} & -0.175\end{array}$




\subsection{ANALYSIS OE REACTION RATE MEASUREMENTS}

Reaction rates were calculated with the xyz diffusion models and 28 group cross sections, as described in Section 3.4. The effects of the banked shim control rods were approximated in the model by adding boron to the fuel in the shim location, to the appropriate shim-insertion depth, and using a shielding factor derived to reproduce the measured shim reactivity to within $10 \%$. This method was deemed sufficiently accurate since reaction rate perturbations at the midplane are generally less than $1 \%$. The model is estimated to be accurate to $0.1 \%$ at the midplane.

Figure 5.1 shows the calculated perturbation in fission rates due to the shim rods in $2 P P R-13 A$. In this case the effects are quite small with relative perturbations of $0.5 \%$ at the most. The calculated shim rod reactivity was $5 \notin$.

The effects due to anisotropic diffusion vary up to $1 \%$ as shown in Section 3.3. In the absence of other perturbations, comparison of C/E values for reaction rates at equivalent positions on the $x$ and $y$ axes of $Z P P R-13 A$ should provide a test of the accuracy of calculated shim rod and streaming effects. Other ZPPR-13 cores have more complex internal blanket geometry.

Corrections for the variations in drawer compositions have been applied by multiplying the reaction rates calculated with the xyz model, $R$ (xyz), by the ratio of reaction rates from the all-master $x y$ model, $R$ (AMM) to the reaction rate for the homogenized-master $x y$ model, $R(H M M)$ as follows:

$$
R(\text { corrected })=R(\text { xyz) } \times R(A M M) / R(H M M)
$$

In the case of axial traverses, the result at each axial position is multiplied by the ratio calculated at the midplane from the $x y$ models.

The experimental measurements are given in units of $10^{-18}$ fissions or captures per atom per second at a reactor power of approximately 1 watt. However, the normalization of the measurements is accurate only to about $20 \%$. 
For comparison with experiment, the calculated values are normalized to give an average $C / E$ value of unity for all available measurements of $f$ ission in ${ }^{239} \mathrm{Pu}$ within the fuel regions. The normalization is not quite equivalent between different cores because the number of measurements for plutonium fission is 1 imited and different traverses may be chosen in each case. Further, the plutonium measurements are normally made in one quadrant only and do not allow for asymetries in the cores. The actual C/E results cannot be compared from core to core to better than a few percent; only the comparisons of the reaction rate distributions and reaction rate ratios are relevant.

Two foil irradiations were made in each of the assemblies $2 P P R-13 A$, The two sets of data have been combined into one group for the present analysis. A number of $235 \mathrm{y}$ foils were irradiated in common locations for each pair of measurements. Except for 2 PPR-13A, the results for the "common foils" were in satisfactory agreement with the experimental statistics. The results for $13 \mathrm{~A}$ showed a small bias. The original data for the separate irradiat ions have been preserved in the monthly $\mathrm{TM}$ reports.

The cross sections used to calculate reaction rates are cell-averaged for each cell type. In the case of plutonium in blanket zones, special cross sections resonance shielded for the $0.13 \mathrm{~mm}$ thick foils are generated. These show improvements over infinitely-dilute cross sections of up to $1 \%$ in the internal blankets and several percent in the soft spectrum regions of the radial and axial blankets.

For convenience in displaying the results, the following abbreviations are used to show the distinctive reactor zones:

CB for center blanket

F1, F2, F3, for fuel rings one, two and three 
B1, 32 for the first and second internal blanket rings

RB for the radial blanket

$A B$ for the axial blanket

In addition, the single-fuel-column drawers in the fuel zones are designated as $F 1 \mathrm{~S}$, etc. Th is distinction is useful since systematic differences in $\mathrm{C} / \mathrm{E}$ results for reactions in $238 \mathrm{U}$ are evident between the single- and double-fuelcolumn drawers.

As an aid in visualizing the analysis of the reaction rates, the results in the sumary tables and figures show mean $C / E$ values for groups of adjacent measurements in the same zone. Very little loss of information is incurred by this condensation since any variation in C/E values over a range of several drawers is masked by experimental statistics. The detailed tables show the standard deviation of the $\mathrm{C} / \mathrm{E}$ distributions for the chosen groups of foils. These data are not usually of statistical significance, due to the small number of results in the group, but are given as an indication of the spread in results. The standard deviations may be compared to the experimental statistics of $0.5 \%$ to $1 \%$ for the non-threshold reactions.

Radial reaction rate distributions along the $x$-axis of $Z P P R-13 A$ are shown in Figs. 5.2 and 5.3. The threshold fission rate, $238_{U}(n, f)$, a monitor of the flux variations in the MeV range, varies quite dramatically between the fuel and blanket rings. This presents a definite challenge to analys is in heterogeneous cores. Its accurate prediction is sensitive to cell-processing methods and to transport effects. In contrast, the non-threshold reactions are quite benign. These variations are typical of the reaction rates in all phases of ZPPR-13 and similar to those in in other heterogeneous cores. (7) 


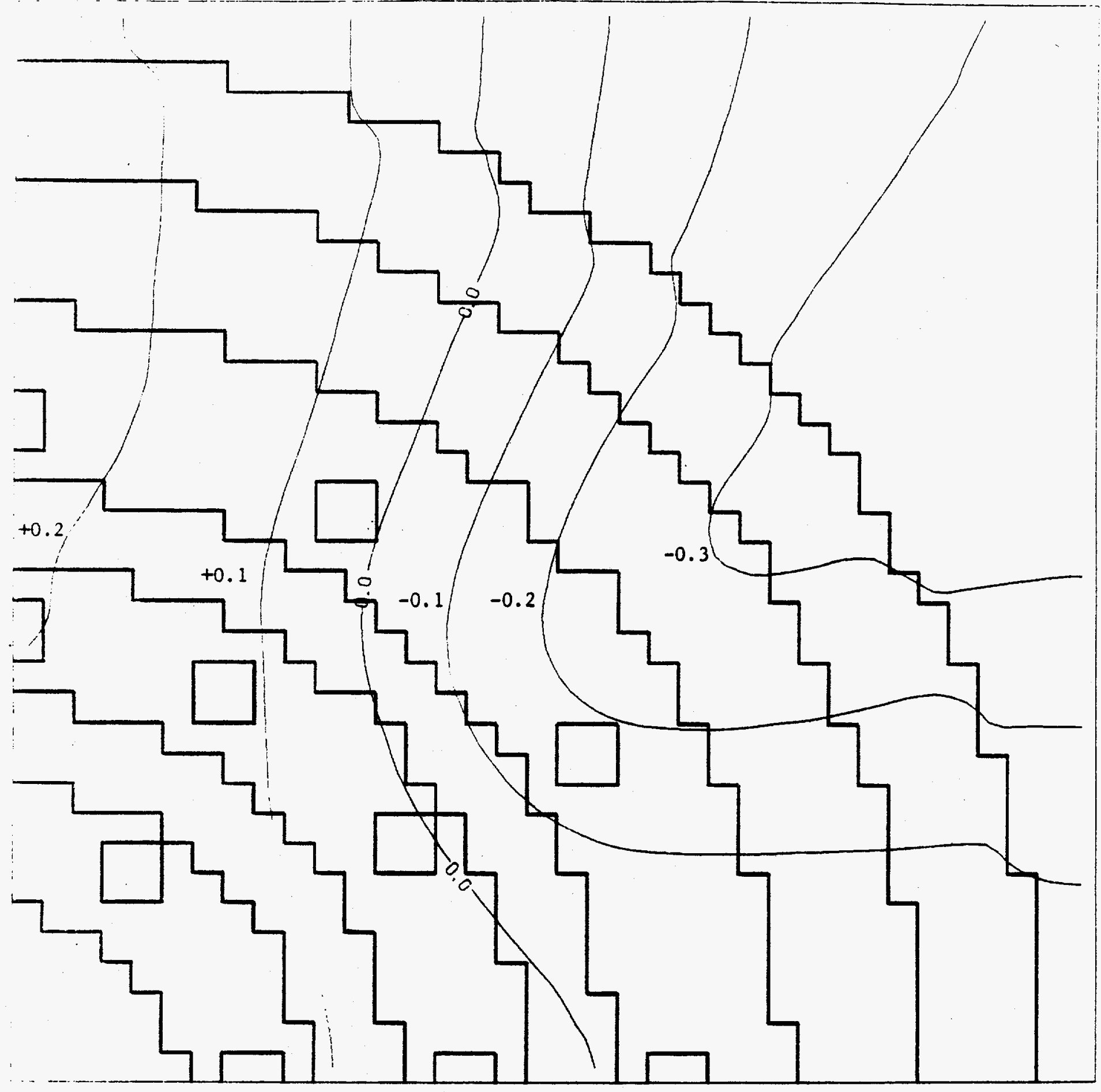

CINTEUR FROM -1.0000 TE 1.6000 CENTEUR INTERVA OF 0.10000 PT $(3.3)=0.17500$

Fig. 5.1. Percent change in ${ }^{235}$ U fission rate in 2PPR-13A caused by partially inserted shim rods. 


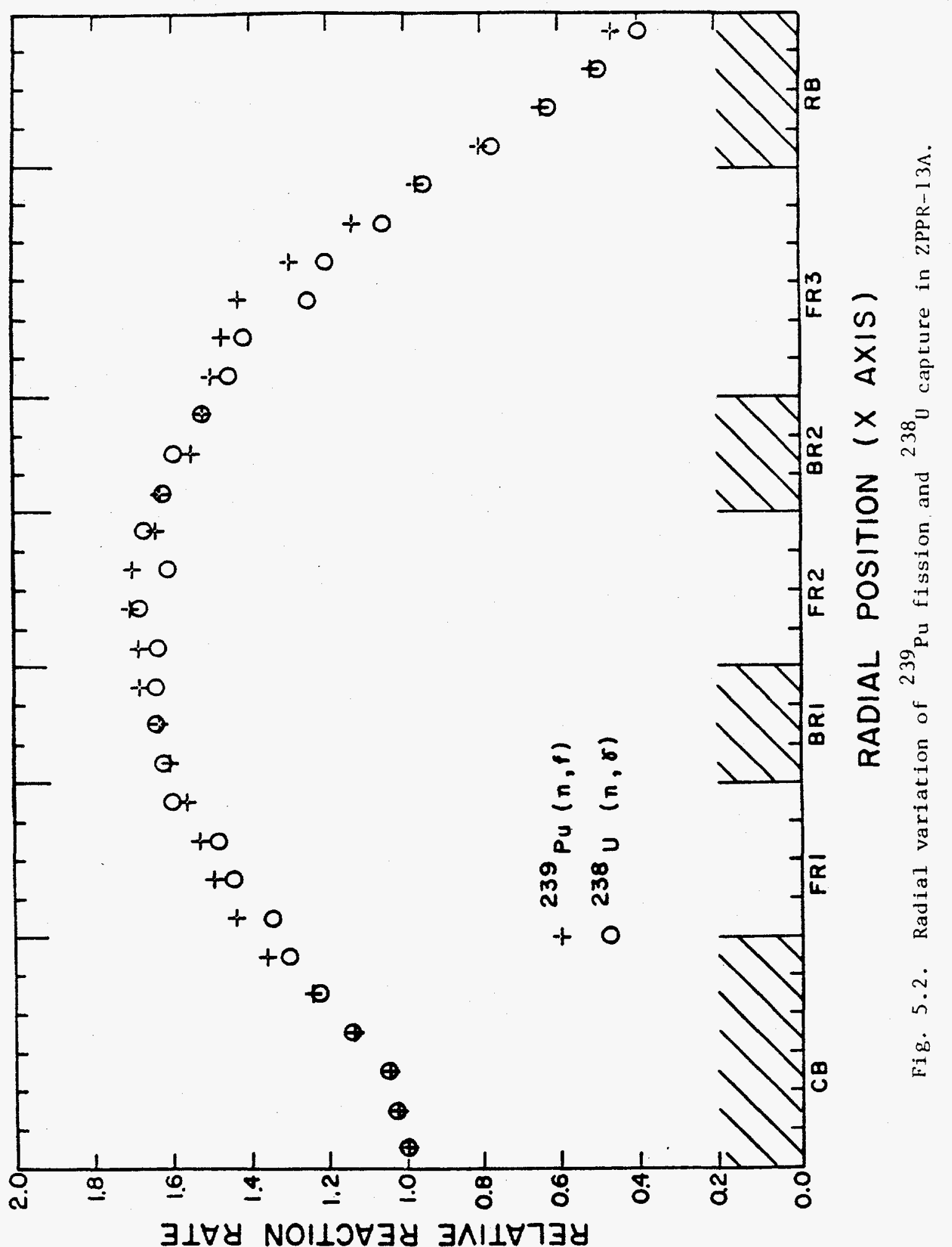




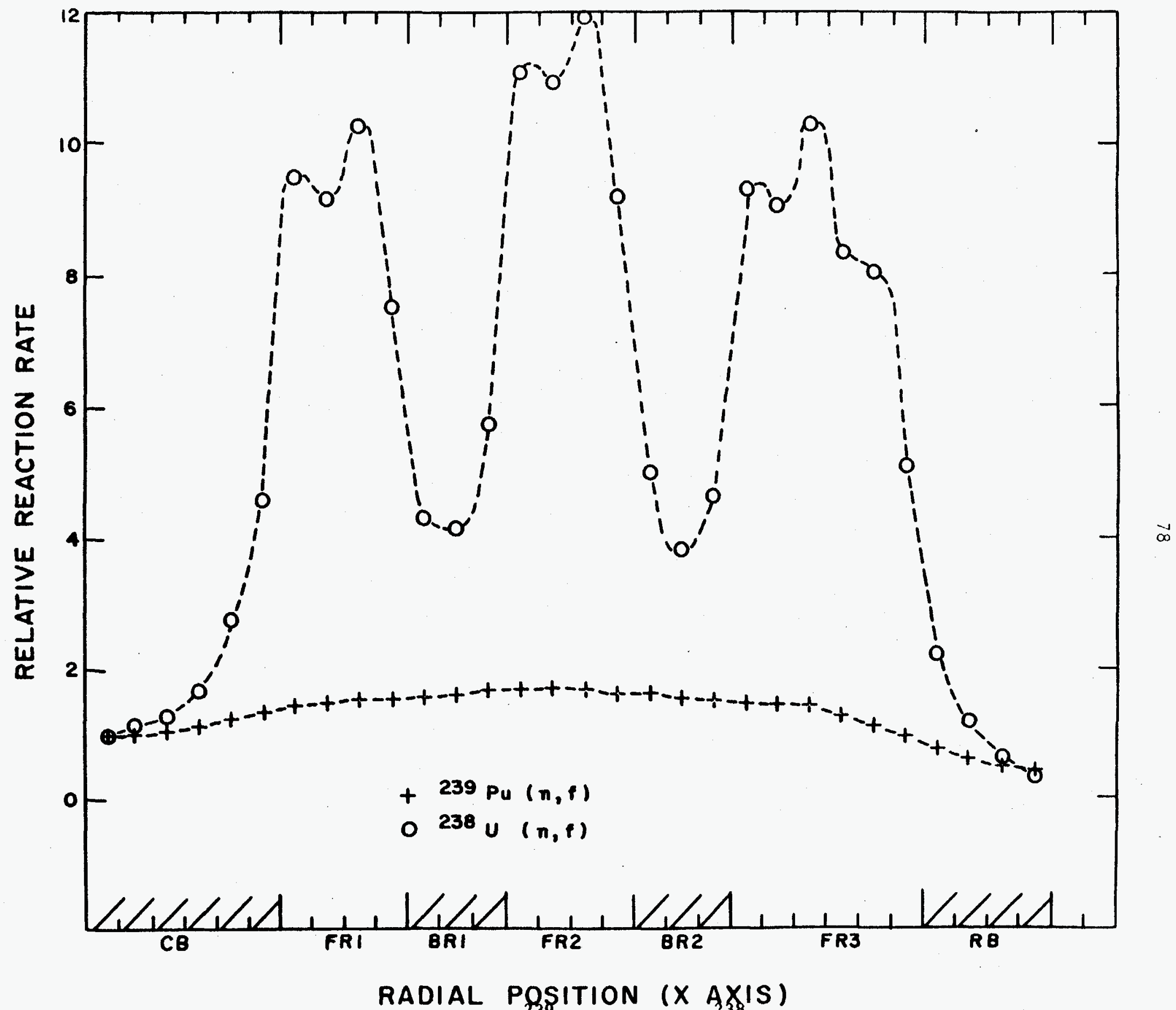

Fig. 5.3. Radial variation of ${ }^{2}$ Pu fission and ${ }^{2}$ fission in ZPPR-13A. 
5.1 Difiuidon Theory Analysis for 2PPR-13A

The locations of the foil measurements in $2 P P R-13 A$ are shown in $F i g s$. 5.4 and 5.5. The data Eall into several groups:

(i) Traverses along the principal axes in the upper left hand (ULH) quadrant for all four reaction types.

(ii) Axial traverses for the four reactions in three locations in fuel zones.

(iii) Extensive data for $235_{\mathrm{U}}$ fission in all four quadrants to test the symmetry of fission distributions.

(iv) A number of special measurements of $235 \mathrm{U}$ fission including twelve axial traverses, measurements near the interface in the radial reflector and measurements in locations symmetric to fission chamber deposits for calibration purposes.

The two irradiations in $2 P P R-13 A$ were separated by an interval of over three months. Several other experiments took place between the two foil measurements, not the least of which were extensive sodium-void studies and "drawer-pushing" excercises. (9) There were $102235_{U}$ foils in the same locations for the two irradiations. The average of the ratios of the countrates in the first set divided by those in the second set (weighted with statistical uncertainties) was $1.0023 \pm 0.0008(1 \sigma)$. This indicates a slight bias between the two measurements, but it is not considered too large to prohibit combination of the two sets of data.

The $k_{e} f f$ values for the xyz calculation models were:

- reference core 0.978908

- with shim rods inserted 0.978757

- shim rod reactivity $0.015 \% \Delta k$ 
The measured shim reactivities were $0.015 \% \Delta_{k}$ and $0.021 \% \Delta_{k}$ for the two irradiations. The single calculation was regarded as adequate since perturbations to midplane reaction rates were less than $0.4 \%$ (Fig. 5.1).

The analysis of radial and axial reaction rate distributions is summarized in Tables 5.1 to 5.7. These results are a condensation of the detailed data in Appendix $C$. The conclusions are as follows:

(i) Radial reaction rate distributions are obtained for all four reaction types only in the upper left hand quadrant. Table 5.1 shows the mean C/E results in each radial zone.

The three non-threshold reactions show a similar monotonic increase in $\mathrm{C} / \mathrm{E}$ with increasing radius. Reaction rates in fuel $\mathrm{r}$ ing two (F2) are overpredicted by $2 \%$ relative to $\mathrm{F} 1$ and reaction rates in $\mathrm{F} 3$ are overpredicted by between $4.5 \%$ and $5 \%$ relative to $\mathrm{F} 1$.

The $238_{U}$ fission rates also show a radial misprediction. However, C/E results in adjacent fuel and blanket zones differ by about $15 \%$. This result is entirely expected with diffusion theory calculations.

(ii) More than 300235 foils were irradiated near to the midplane, covering all four quadrants of the reactor. These results are displayed in Table 5.2 to show the azimuthal variations in prediction. The results are also illustrated in Fig. 5.6. The azimuthal variation in $C / E$ is about $3 \%$ in the third fuel ring (F3). The highest value is 1.066 on the negative $x-a x$ is and the lowest value is 1.036 near the top of the core. Results at the bottom of the core are about $1 \%$ higher than at the top and results on the RHS are generally lower than on the LHS.

(iii) Table 5.3 shows a summary of results for the 64 foils in locations symmetric to the in-core fission chambers. Results are averaged for each radial zone. These data are sufficient to identify the radial mispredictions of 
fission rates as can be seen by comparison with the results fron all $235_{U}$ foils, shown in the last column of the table.

(iv) Axial traverses were made adjacent to or inside each of the twelve positions designated as control rod locations in the outer fuel ring. The average C/E results in these locations, shown in Table 5.4, provide data on the azimuthal variation covering all four quadrants. The results show a similar variation to those in Table 5.3 although values in the same regions tend to be higher by $0.5 \%$ to $1 \%$.

(v) Tables 5.5, 5.6 and 5.7 give an analys is of axial reaction rate distributions. In order to remove biases in $C / E$ values due to position in the core and reaction type, the tables show the $\mathrm{C} / \mathrm{E}$.values at each $z$-position relative to a core average value. Since the foil locations are irregularlyspaced, an axially-weighted core-average is used (this is only a little different from the unweighted average (see results in Appendix $c$ )). With this normalization, all results except $238_{\mathrm{U}}$ fission show a similar trend.

The $\mathrm{C} / \mathrm{E}$ results at the top of the core near the axial blanket interface are $1 \%$ low, on average, relative to the mean over the core height. The results in the axial blanket have consistent C/Es, within statistics, over the range $480 \mathrm{~mm}$ to $690 \mathrm{~mm}$ from the midplane. The results for $238 \mathrm{y}$ capture appear less consistent between the core region and the blanket. In the axial blanket above the single-fuel-column drawer (Table 5.5) the $\mathrm{C} /$ Es are about $2 \%$ higher, but above the double-fuel-column drawer (Table 5.6 ) the $\mathrm{C} /$ Es are about $5 \%$ lower than the core average. The $238 \mathrm{U}$ fission values across the core/axial blanket interface show a marked discontinuity of $5 \%$ to $10 \%$ in the same sense as found in the radial distributions. 
1415161718192021222324252627282930313233343536373839404142434445464748495051

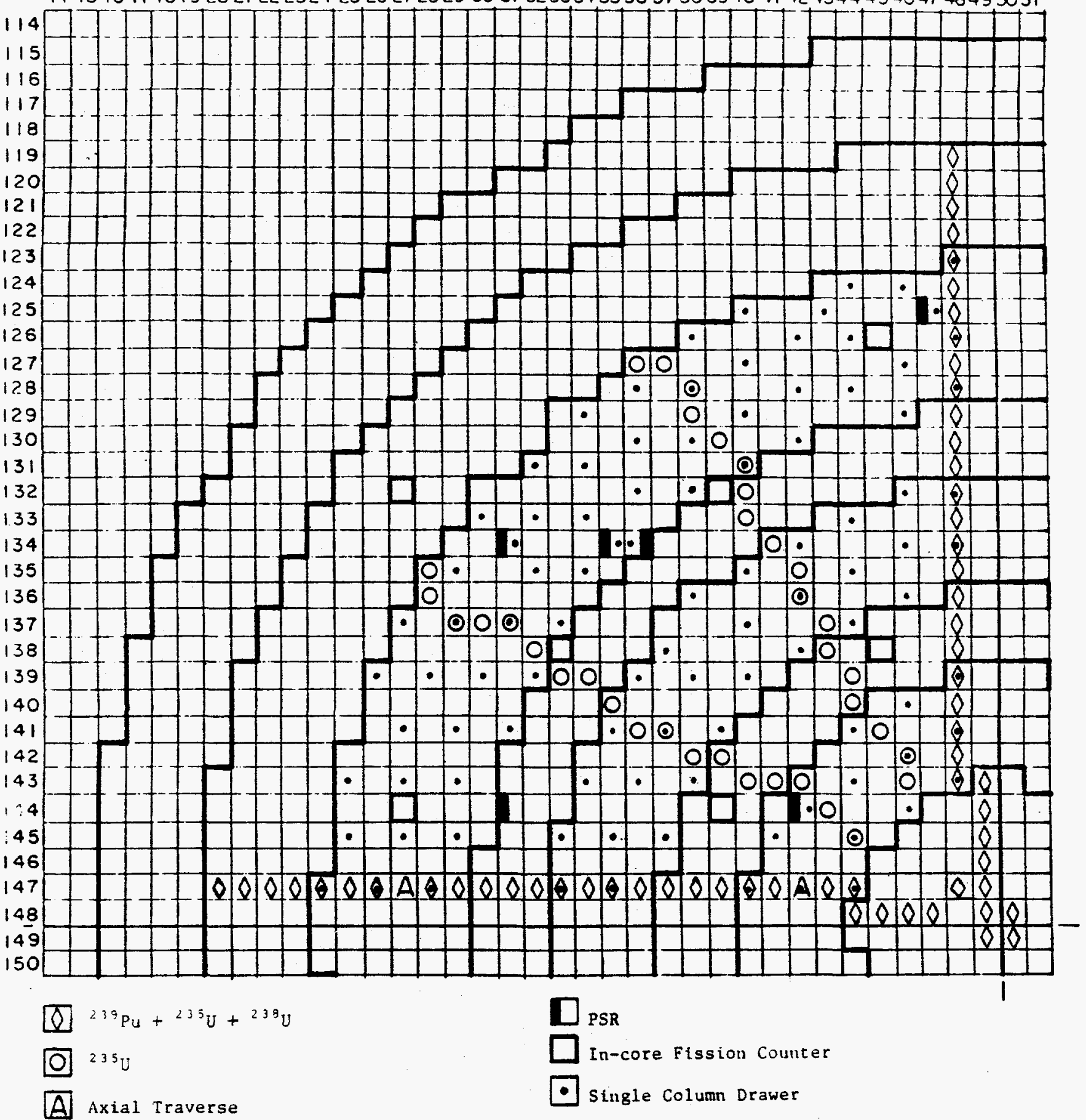

Fig. 5.4. Foil Locations in ZPPR-13A Irradiation No. 1. 


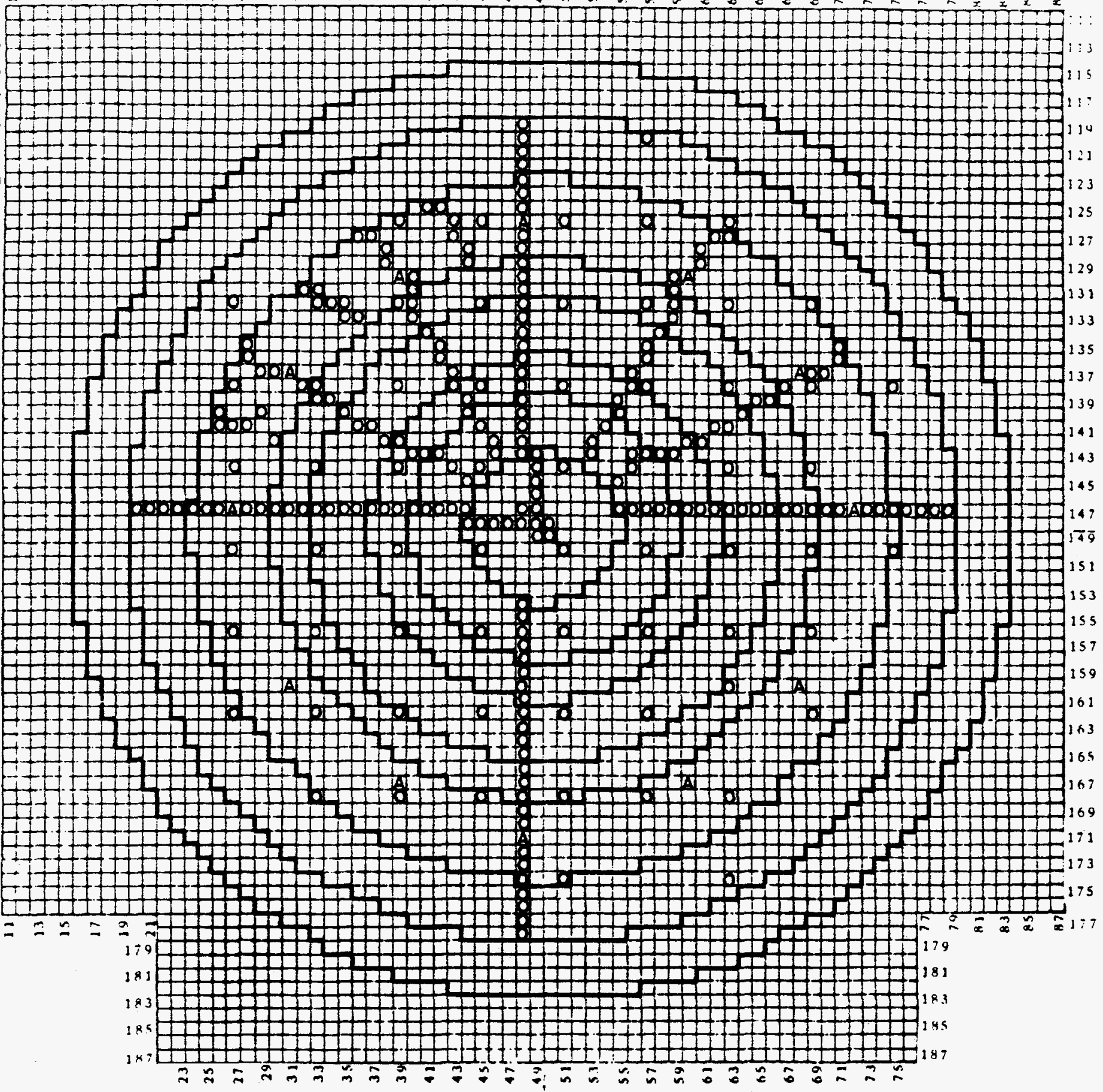

$\square$
0
$03{ }^{5} \mathrm{U}$ Foil

Fig. 5.5. Foil Locations in 2PPR-13A Irradiation No. 2. 


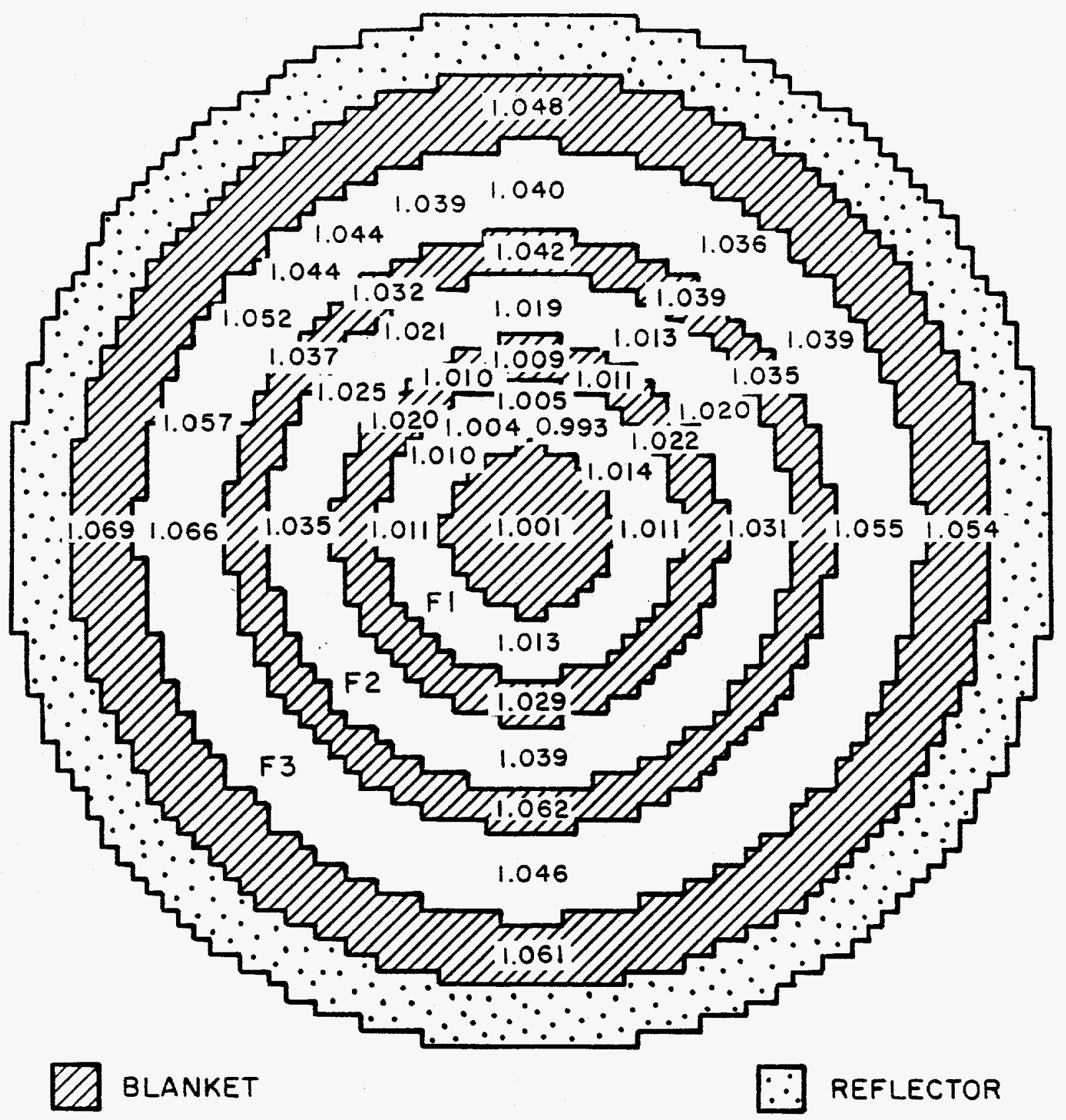

$F 1, F 2, F 3$, FUEL ZONES

Fig. 5.6. Ratios of calculation to experiment for ${ }^{235} \mathrm{U}$ fission rates in $2 P P R-13 A$. 
TABLE 5.1. 2PPR-13A: Summary of Radial Reaction Rate Analysis

\begin{tabular}{|c|c|c|c|c|c|c|c|c|c|}
\hline \multirow[b]{2}{*}{ Zone } & \multirow{2}{*}{$\begin{array}{l}\text { Number } \\
\text { of Data } \\
\end{array}$} & \multicolumn{2}{|c|}{${ }^{23} 9 \mathrm{Pu}(\mathrm{n}, \mathrm{f})$} & \multicolumn{2}{|c|}{$235 u(n, f)^{a}$} & \multicolumn{2}{|c|}{$238^{U} U(n, \gamma)$} & \multicolumn{2}{|c|}{$23{ }^{8} \mathrm{U}(\mathrm{n}, \mathrm{f})$} \\
\hline & & Mean C/E & S.D.b & Mean $\mathrm{C} / \mathrm{E}$ & S.D.b & Mean $C / E$ & S.D.b & Mean C/E & S.D.b \\
\hline CB & 14 & 0.969 & 0.011 & 1.005 & 0.007 & 1.045 & 0.007 & 0.961 & 0.089 \\
\hline F 1 & 10 & 0.974 & 0.011 & 1.008 & 0.009 & 1.048 & 0.015 & 0.908 & 0.029 \\
\hline B 1 & 6 & 0.987 & 0.008 & 1.013 & 0.006 & 1.050 & 0.007 & 1.060 & 0.019 \\
\hline B2 & 6 & 1.022 & 0.018 & 1.051 & 0.012 & 1.077 & 0.011 & 1.091 & 0.034 \\
\hline F3 & 12 & 1.020 & 0.023 & 1.053 & 0.014 & 1.099 & 0.025 & 0.966 & 0.039 \\
\hline RB & 8 & 0.997 & 0.025 & 1.058 & 0.014 & 1.095 & 0.019 & 1.003 & 0.092 \\
\hline
\end{tabular}

ancludes only results at the $x$-axis and $y$-axis in the uLH quadrant for consistency with the other reactions.

${ }^{b_{S t}}$ andard deviation of the $\mathrm{C} / \mathrm{E}$ distribut ion.

JA I I 2 A 24 
TABLE 5.2.

2PPR-13A: Summary of Radial Fission Rate Analys is for $235 \mathrm{U}$

\begin{tabular}{|c|c|c|c|c|c|c|}
\hline \multirow{2}{*}{$\begin{array}{l}\text { Azimuthal } \\
\text { Posit ion }\end{array}$} & \multicolumn{6}{|c|}{ Mean C/E by Radial Zoneb } \\
\hline & FI & $\mathrm{Bl}$ & $F 2$ & B2 & F3 & $\overline{R B}$ \\
\hline Negat ive $x$-ax is & 1.011 & 1.017 & 1.035 & 1.060 & 1.066 & 1.069 \\
\hline$\pi / 12$ & -- & -- & -- & -- & 1.057 & -- \\
\hline$\pi / 6$ & 1.010 & 1.020 & 1.025 & 1.037 & 1.052 & --- \\
\hline $3 \pi / 12$ & -- & $-\infty$ & -- & $-\infty$ & 1.044 & --- \\
\hline$\pi / 3$ & 1.004 & 1.010 & 1.021 & 1.032 & 1.044 & --- \\
\hline $5 \pi / 12$ & -- & -- & $-\infty$ & -- & 1.039 & -- \\
\hline Positive $y$-ax is & 1.005 & 1.009 & 1.019 & 1.042 & 1.040 & 1.048 \\
\hline $2 \pi / 3$ & 1.014 & 1.022 & 1.020 & 1.035 & 1.039 & --- \\
\hline $5 \pi / 6$ & 0.993 & 1.011 & 1.013 & 1.039 & 1.036 & -- \\
\hline Posit ive $x$-axis & 1.011 & 1.024 & 1.031 & 1.066 & 1.055 & 1.054 \\
\hline Negat ive $y$-axis & 1.013 & 1.029 & 1.039 & 1.062 & 1.046 & 1.061 \\
\hline Al1 Data: & & & & & & \\
\hline Number & 38 & 29 & 43 & 31 & 140 & 22 \\
\hline Mean C/E & 1.008 & 1.018 & 1.024 & 1.045 & 1.046 & 1.061 \\
\hline S.D. & 0.011 & 0.012 & 0.013 & 0.014 & 0.014 & 0.014 \\
\hline
\end{tabular}

TABLE 5.3. ZPPR-13A: Summary of Analys is for the Fission Chamber Calibration Foils

\begin{tabular}{|c|c|c|c|c|}
\hline Zone & $\begin{array}{c}\text { Number } \\
\text { of Results } \\
\end{array}$ & $\begin{array}{r}\text { Mean } \\
\mathrm{C} / \mathrm{E} \\
\end{array}$ & S.D. & $\begin{array}{c}\text { Mean } \mathrm{C} / \mathrm{E} \\
\text { Using all Foil Data }\end{array}$ \\
\hline CB & 3 & 1.004 & 0.002 & 1.005 \\
\hline F 1 & 5 & 1.000 & 0.013 & 1.008 \\
\hline B 1 & 5 & 1.018 & 0.014 & 1.018 \\
\hline F 2 & 11 & 1.019 & 0.010 & 1.024 \\
\hline B2 & 11 & 1.039 & 0.011 & 1.045 \\
\hline E3 & 23 & 1.042 & 0.015 & 1.046 \\
\hline $\mathrm{RB}$ & 6 & 1.069 & 0.014 & 1.061 \\
\hline
\end{tabular}


TABLE 3.4. ZPPR-13A: Summary of Analys is of ${ }^{23} \mathrm{~b} U$ Fission Near Control Positions in Fuel Ring 3

\begin{tabular}{|c|c|c|c|c|}
\hline $\begin{array}{l}\text { Matrix } \\
\text { Position } \\
\end{array}$ & $\begin{array}{c}\text { Control } \\
\text { Position } \\
\end{array}$ & Orientation & $\begin{array}{l}\text { Me an } \\
C / E^{b}\end{array}$ & S.D. \\
\hline $147-27$ & 25 & $0 \quad(-x)$ & 1.062 & 0.012 \\
\hline $137-31$ & 26 & $\pi / 6$ & 1.045 & 0.005 \\
\hline $130-39$ & 27 & $\pi / 3$ & 1.025 & 0.010 \\
\hline $126-48$ & 28 & $\pi / 2(+y)$ & 1.035 & 0.004 \\
\hline $130-60$ & 29 & $2 \pi / 3$ & 1.029 & 0.006 \\
\hline $137-68$ & 30 & $5 \pi / 6$ & 1.041 & 0.008 \\
\hline $147-72$ & 31 & $\pi \quad(+x)$ & 1.051 & 0.009 \\
\hline $160-68$ & 20 & $7 \pi / 6$ & 1.049 & 0.006 \\
\hline $167-60$ & 21 & $4 \pi / 3$ & 1.034 & 0.007 \\
\hline $171-48$ & 22 & $3 \pi / 2(-y)$ & 1.046 & 0.004 \\
\hline $167-39$ & 23 & $5 \pi / 3$ & 1.033 & 0.013 \\
\hline $160-31$ & 24 & $11 \pi / 6$ & 1.057 & 0.013 \\
\hline
\end{tabular}

apositions used for measurement of control rod worths in ZPPR-13A. Positions near the axes were adjacent to control positions, the remainder were inside the control positions.

${ }^{b}$ Mean result for seven or ten axial positions, depending on location. See detailed tables.

JAII $2 A 27$

TABLE 5.5. ZPPR-13A: Axial Reaction Rate Analys is in Matrix 147-42

\begin{tabular}{|c|c|c|c|c|c|}
\hline Zone & $\underline{\mathrm{Z}, \mathrm{mm}}$ & F9 & F5 & $\mathrm{C} 8$ & F8 \\
\hline F1 S & $\begin{array}{r}77 \\
128 \\
204 \\
280 \\
331 \\
382 \\
433\end{array}$ & $\begin{array}{l}1.015 \\
1.009 \\
0.999 \\
0.998 \\
0.988 \\
0.979 \\
0.999\end{array}$ & $\begin{array}{l}1.008 \\
1.002 \\
0.997 \\
1.002 \\
1.010 \\
0.984 \\
0.988\end{array}$ & $\begin{array}{l}1.018 \\
1.001 \\
0.999 \\
1.003 \\
0.982 \\
0.991 \\
0.984\end{array}$ & $\begin{array}{l}1.002 \\
1.008 \\
1.060 \\
1.004 \\
0.969 \\
0.971 \\
0.950\end{array}$ \\
\hline$A B$ & $\begin{array}{l}483 \\
534 \\
610 \\
687\end{array}$ & $\begin{array}{l}0.991 \\
1.004 \\
0.981 \\
0.966 \\
\end{array}$ & $\begin{array}{l}1.006 \\
1.001 \\
0.986 \\
0.999 \\
\end{array}$ & $\begin{array}{l}1.027 \\
1.024 \\
1.017 \\
1.007 \\
\end{array}$ & $\begin{array}{l}0.998 \\
1.004 \\
0.89 \\
0.81 \\
\end{array}$ \\
\hline Core & $\begin{array}{c}\text { Average }{ }^{a} \\
\text { S.D. }\end{array}$ & $\begin{array}{l}0.984 \\
0.012\end{array}$ & $\begin{array}{l}1.017 \\
0.010\end{array}$ & $\begin{array}{l}1.034 \\
0.013\end{array}$ & $\begin{array}{l}0.956 \\
0.035\end{array}$ \\
\hline
\end{tabular}


TABLE 5.6. 2PPR-13A: Axial Reaction Rate Analys is in Matrix 147-27

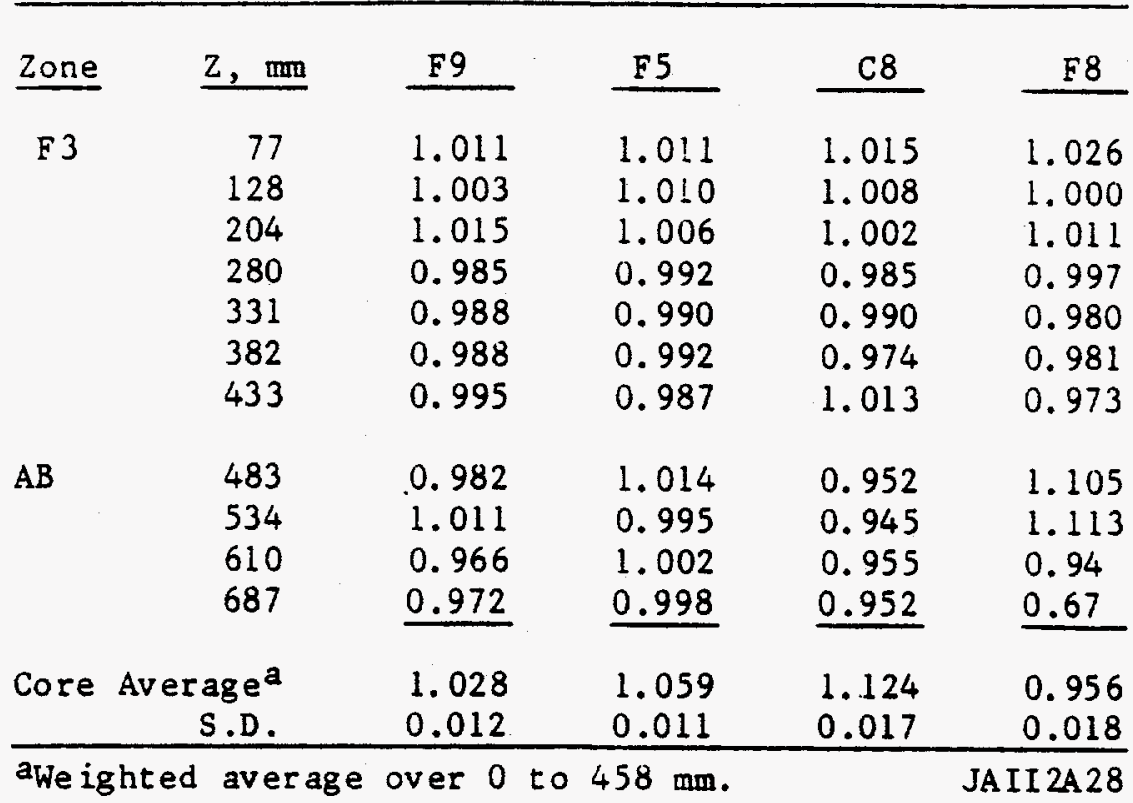


TABLE 5.7. Summary of Axial $235_{U}$ Fission Race Analysis

\begin{tabular}{|c|c|c|c|c|c|c|}
\hline $\mathrm{Z}, \mathrm{mm}$ & $147-27$ & $137-31$ & $130-39$ & $126-48$ & $130-60$ & $137-68$ \\
\hline 13 & 1.014 & 1.004 & 0.997 & 0.998 & 1.005 & 1.006 \\
\hline 77 & 1.010 & 1.001 & 1.004 & 1.001 & 1.010 & 0.987 \\
\hline 128 & 1.009 & 1.005 & 1.023 & 1.002 & - & - \\
\hline 204 & 1.006 & 1.000 & 1.003 & 1.006 & - & $-\cdots$ \\
\hline 280 & 0.992 & 1.000 & 0.997 & 1.002 & 0.997 & 1.001 \\
\hline 331 & 0.990 & 0.996 & 0.993 & 0.997 & 0.999 & 0.999 \\
\hline 382 & 0.992 & 0.995 & 0.994 & 0.993 & 0.993 & 0.997 \\
\hline 433 & 0.987 & 0.995 & 0.982 & 0.999 & -- & -- \\
\hline
\end{tabular}

Core

\begin{tabular}{|c|c|c|c|c|c|c|}
\hline \multirow[t]{2}{*}{ Average } & 1.059 & 1.044 & 1.026 & 1.036 & 1.027 & 1.040 \\
\hline & $147-72$ & $160-68$ & $167-60$ & $171-48$ & $167-39$ & $160-31$ \\
\hline 13 & 1.005 & 0.995 & 1.007 & 0.999 & 1.009 & 1.008 \\
\hline 77 & 1.005 & 1.003 & 1.008 & 0.996 & 1.010 & 1.019 \\
\hline 128 & 1.008 & -- & $-\infty$ & 1.000 & -- & -- \\
\hline 204 & 1.007 & -- & -- & 1.004 & --- & -- \\
\hline 280 & 1.003 & 1.003 & 0.998 & 1.001 & 1.000 & 0.999 \\
\hline 331 & 0.992 & 1.004 & 0.995 & 1.001 & 0.997 & 0.987 \\
\hline 382 & 0.994 & 0.999 & 0.994 & 0.998 & 0.996 & 0.989 \\
\hline 433 & 0.980 & --- & --- & 0.995 & -- & -- \\
\hline
\end{tabular}

Core

\begin{tabular}{llllllll} 
Average $^{a}$ & 1.050 & 1.050 & 1.032 & 1.047 & 1.030 & 1.054 \\
\hline Average of all results & at & 13 & and & 77 & $\mathrm{~mm}$ & $=1.004$ &
\end{tabular} Average of all results at 382 and $433 \mathrm{~mm}=0.993$

awe ighted average over 0 to $458 \mathrm{~mm}$.

JAII 2A 29 


\subsection{Reaction Rate Ratio Analys is}

Reaction rate ratios relative to fission in ${ }^{239} \mathrm{Pu}$ have been analyzed for all matrix positions in wich all three foils were irradiated. Detailed results are given in the appendices. Note that the experimental values are not adjusted to a common $10 c$ ation in the cell. The $235_{U}$ foils are separated from the plutonium foils by $27.7 \mathrm{~mm}$ and the $238_{\mathrm{U}}$ foils are separated from plutonium foils by $13.8 \mathrm{~mm}$. The adjustments would be about $1 \%$ for $235_{U}$ and $0.5 \%$ for $238_{U}(n, \gamma)$. Variations in 238 fission may be much larger. Calculations are interpolated to the given foil locations to obtain appropriate C/E values. The C/E values are insensitive to mispredictions of the global flux shapes in the core since these are similar for all reactions. For a given cell type, the standard deviations of the C/E distributions are only a little larger than the statistical uncertainties of the measurements.

A summary of the reaction rate ratio analys is for $Z P P R-13 A$

$$
\text { is given in Table } 5.13 \text { Average results are given }
$$

separately for single-fuel-column and double-fuel-column drawers and for blanket drawers since significantly different results may be obtained in different drawer types.

The conclusions are:

(i) Results are consistent between these cores and are similar to analys is of $2 P P R-9$ and $Z P P R-10$.

(ii) The average $C / E$ for the $235 \mathrm{U}$ fission $r$ atio is 1.03 and varies by only a few tenths of a percent between SC fuel drawers, DC fuel drawers and blanket drawers except for the axial traverses in $13 B / 4$ which are singularly out of $l$ ine $(C / E=1.044)$.

(iii) The results for the $238_{\mathrm{U}}$ capture ratio are significantly different between the drawer types: 
$\mathrm{SC}$ Euel drawers $\langle\mathrm{C} / \mathrm{E}\rangle=1.06$

$D C$ fuel drawers $\langle C / E\rangle=1.09$

Internal $\mathrm{Bl}$ ankets $\langle\mathrm{C} / \mathrm{E}\rangle=1.07$

(iv) The results for the $238 \mathrm{U}$ fission ratios are also different.

For radial traverses:
SC fue 1 drawers $\langle C / E\rangle=0.95$ to 0.97
$D C$ fuel drawers $\langle C / E\rangle=0.92$ to 0.93
Internal $B 1$ ankets $\langle C / E\rangle=1.07$ to 1.08

The $238 \mathrm{~J}$ fission results are improved by fine mesh transport calculations. 


\section{$112 / 13$}

TABLE 5.13.

ZPPR-13A: Summary of Reaction Rate Ratio Analys is

\begin{tabular}{|c|c|c|c|c|c|}
\hline Ratio & Traverse & Zone $^{a}$ & $\begin{array}{l}\text { Number of } \\
\text { Results }\end{array}$ & Mean C/E & $\begin{array}{l}\text { St andard } \\
\text { Deviation }\end{array}$ \\
\hline $23{ }^{3} \mathrm{U}(\mathrm{n}, E) /{ }^{239} \mathrm{Pu}(\mathrm{n}, E)$ & Axial & $\begin{array}{l}\text { Fuel DC } \\
\text { Fuel SC } \\
\text { Internal Blankets } \\
\text { Fuel DC } \\
\text { Fuel SC }\end{array}$ & $\begin{array}{r}14 \\
16 \\
26 \\
7 \\
7\end{array}$ & $\begin{array}{l}1.027 \\
1.032 \\
1.033 \\
1.028 \\
1.034\end{array}$ & $\begin{array}{l}0.012 \\
0.011 \\
0.014 \\
0.007 \\
0.013\end{array}$ \\
\hline $238 U(n, \gamma) /{ }^{239} \mathrm{Pu}(n, f)$ & $\begin{array}{l}\text { Radial } \\
\text { Axial }\end{array}$ & $\begin{array}{l}\text { Fuel DC } \\
\text { Fuel SC } \\
\text { Internal Blankets } \\
\text { Fuel DC } \\
\text { Fuel SC }\end{array}$ & $\begin{array}{r}14 \\
16 \\
26 \\
7 \\
7\end{array}$ & $\begin{array}{l}1.091 \\
1.060 \\
1.070 \\
1.092 \\
1.049\end{array}$ & $\begin{array}{l}0.012 \\
0.014 \\
0.015 \\
0.012 \\
0.010\end{array}$ \\
\hline $23{ }^{8} \mathrm{U}(\mathrm{n}, \mathrm{f}) /{ }^{239} \mathrm{Pu}(\mathrm{n}, \mathrm{f})$ & Axial & $\begin{array}{l}\text { Fuel DC } \\
\text { Fuel SC } \\
\text { Center Blanket } \\
\text { Internal Blankets } \\
\text { Fuel DC } \\
\text { Fuel SC }\end{array}$ & $\begin{array}{r}14 \\
16 \\
8 \\
18 \\
7 \\
7\end{array}$ & $\begin{array}{l}0.915 \\
0.953 \\
0.921 \\
1.078 \\
0.933 \\
0.970\end{array}$ & $\begin{array}{l}0.018 \\
0.024 \\
0.032 \\
0.023 \\
0.012 \\
0.033\end{array}$ \\
\hline
\end{tabular}

$\widehat{a_{D C}}=$ double-fuel-column drawers; $S C=$ single-fuel-column fuel drawers.

bIncludes positions in interior of center blanket. Positions near the edge are averaged with the internal blanket rings. 


\subsection{Transport Calculation}

Transport calculations using a fine mesh (4MPD) have been calculated for the midplane reaction rates in $2 P P R-13 A$ using an $x y$ model. The results for the xyz diffusion calculations have been adjusted first by the ratio of diffusion calculations in 4MPD relative to $1 \mathrm{MPD}$ and second by the ratio of the $\mathrm{S}_{4}$ calculation with 4MPD to the diffusion calculation with 4MPD.

The transport corrections along the $x$-axis are given in Tables 5.16 to 5.19. Corrections are quite similar for the three non-threshold reactions; reaction rates in blanket regions are reduced by between $2 \%$ and $3 \%$ while values in fuel regions change by less than $0.5 \%$. (Note that the transport results preserve the normalization to ${ }^{239} \mathrm{Pu}$ fission in the fuel zones). The mispredictions with radius are made marginally worse $(0.3 \%$ to $0.5 \%)$ by transport corrections.

Transport corrections produce a marked improvement for $238_{U}(n, f)$. Calculated values in fuel regions are increased by between $1 \%$ and $3 \%$, values in the internal blankets are decreased by between $6 \%$ and $13 \%$. C/E results between the fuel zones F1 and F2 remain lower than those in blanket zones B1 and B2 by $5 \%$.

Studies for $2 P P R-7$, using fuel/blanket coupled-cell models achieved agreement in predictions of $238_{U}$ fission between fuel and blanket drawers to within $2 \%$. (7) Calculations for $2 P P R-13$ with multi-drawer models might al so produce improved predictions. 
MATRIX

POSITION ZONE

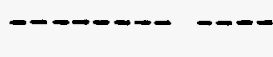

14749

$14748 \quad C B$

$14847 \quad C B$

$148 \quad 46 \quad C B$

$148 \quad 45 \quad C B$

$14844 \quad C B$

$14744 \quad$ Fl S

$14743 \quad$ Fl

$14741 \quad F 1$

$14740 \quad$ FI S

$14739 \quad B 1$

$14738 \quad \mathrm{Bl}$

$14737 \quad$ B1

$147 \quad 36 \quad F 2$

14735 F2 S

$14734 \quad$ F2

$14733 \quad$ F2 S

$147 \quad 32 \quad$ B2

14731 B2

$14730 \quad$ B2

$14729 \quad F 3$

14728 F3 S

14726 F3 S

$\begin{array}{lll}147 & 25 & \text { F3 }\end{array}$

14724 F3 S

$14723 \mathrm{RB}$

14722 RB

$14721 \quad \mathrm{RB}$

14720 RB
TABLE 5.16. ZPPR-13A: TRANSPORT CORRECTED REACTION RATES FOR 239PU(N,F)
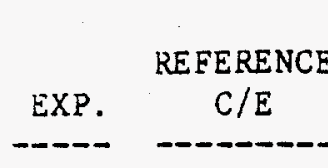

4.473

4.588

4. 669

5.095

5.610

6.118

0.959

0.966

0.980

0.979

0.975

0.980

6.146

0.958

6.434

6.895

0.971

7.023

0.974

0.968

0.968

$(0.007)$

0.973

$(0.009)$

7.222

7.350

0.984

7.559

0.992

0.998

7.567

0.997

7.709

1.015

7.654

1.007

7.403

1.017

7.343

6.985

1.016

1.040

6.847

1.048

0.991

$(0.007)$

1.005

1.009

1.009

1.008

1.007

1.005

1.003

1.003

1.001

1.002

1.004

0.967

0.966

0.966

0.964

0.969

0.974

1.005

1.003

0.988

1.003

1.001

0.984

CORRECTED

$\mathrm{C} / \mathrm{E}$

MEAN C/E

(S.D.)

$\cdots$

0.936
0.940
0.954
0.951
0.949
0.958

0.948

$(0.008)$

0.949

0.975

0.978

0.957

0.965

$(0.014)$

(0.007)

\subsection{2}

1.000

0.966

0.965

0.974

1.009

1.001

1.001

1.003

(0.009)

1.002

1.006

0.990

0.955

0.962

0.975

0.964

(0.010)

6.764

1.022

6.611

1.045

5.818

1.047

5.102

1.059

4. 388

1.023

1.039

1.003

0.970

1.035

1.004

0.970

1.002

0.973

0.999

1.018

1.014

1.008

1.010

$(0.008)$

(0.017)

1.000

1.000

0.997

0.996

1.006

0.997

1.006

0.998

1.009

0.994

0.988

1.005

1.022

1.005

$(0.017)$

3.628

1.037

2. 911

2. 339

1.016

1.009

0.967

1.007
$(0.029)$

1.000

0.973

0.968

1.002

0.972

0.981

1.009

1.022

1.048

1.049

1.065

1.014

1.040

$(0.021)$

1.009

0.985

0.986

0.957

0.984

$(0.021)$

A CORRECTIONS WERE NOT CALCULATED IN POSITIONS 147-42 AND 147-27. 
TABLE 5.17. ZPPR-13A: TRANSPORT CORRECTED REACTION RATES FOR 235U(N,E)

MATRIX

POSITION ZONE

-- - - - -

$14749 \mathrm{CB}$

$14748 \quad C B$

$14847 \quad C B$

$14846 \quad \mathrm{CB}$

$148 \quad 45 \quad C B$

$14844 \quad \mathrm{CB}$

$14744 \quad$ F1 S

$14743 \quad$ F1

$14741 \quad$ F1

14740 F1 S

$\begin{array}{lll}147 & 39 & B 1\end{array}$

$14738 \quad B 1$

$14737 \quad B 1$

$147 \quad 36 \quad$ F2

$14735 \quad$ F2 S

$\begin{array}{lll}147 & 34 & \text { F2 }\end{array}$

14733 F2 S

$147 \quad 32 \quad B 2$

$\begin{array}{lll}147 & 31 & B 2\end{array}$

$14730 \quad$ B2

$147 \quad 29 \quad$ F3

$14728 \quad$ F3 S

14726 F3 S

$\begin{array}{lll}147 & 25 & \text { F3 }\end{array}$

14724 F3 S

$14723 \quad \mathrm{RB}$

14722 RB

14721 RB

$14720 \quad \mathrm{RB}$
CORRECTIONS A

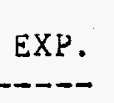

REFERENCE

$\mathrm{C} / \mathrm{E}$

5.306

5.429

5.524

5.981

6.324

6.557

1.000

1.003

1.011

0.996

1.003

1.020

6.492

6.684

7.235

1.021

1.004

0.996

1.012

1.008

(0.011)

1.012

1.018

1.022

1.017

$(0.005)$

8.198

7.977

1.020

1.045

7.970

1.029

1.047

1.035

7.901

(0.013)

1.058

1.061

1.062

1.058

1.069

1.066

1.071

1.062

4.646

1.083

3.935

3.255

2. 667

2. 321
1.069

1.065

1.057
1.060

$(0.002)$

1.065

$(0.005)$

$\begin{array}{cccc} & 0.998 & 0.978 & 1.057 \\ & 1.001 & 0.973 & 1.041 \\ 1.069 & 1.005 & 0.974 & 1.042 \\ (0.011) & 1.010 & 0.981 & 1.047\end{array}$

1.000

1.001

0.999

1.001

0.997

0.995

0.998

0.997

0.998

1.002

1.004

1.006

0.993

0.981

1.031

1.037

1.057

1.068

1.065

1.075

1.051
0.982

$(0.010)$

CORRECTED MEAN C/E

(S.D.)

0.977

0.979

0.986

0.970

0.980

0.999

1.010

1.005

0.996

0.999

1.003

$(0.006)$

0.986

0.991

1.000

0.992

$(0.007)$

1.020

1.042

1.032

1.037

1.033

$(0.009)$

1.032

1.033

$(0.003)$

1.063

$(0.009)$

A CORRECTIONS WERE NOT CALCULATED IN POSITIONS 147-42 AND 147-27. 
TABLE 5.18. ZPPR-13A: TRANSPORT CORRECTED REACTION RATES FOR 238U $(\mathrm{N}, \mathrm{G})$

\begin{tabular}{|c|c|c|c|c|c|c|c|c|}
\hline \multirow{3}{*}{$\begin{array}{l}\text { MATRIX } \\
\text { POSITION }\end{array}$} & \multirow[b]{3}{*}{ ZONE } & \multirow[b]{3}{*}{ EXP. } & \multirow{3}{*}{$\begin{array}{c}\text { REFERENCE } \\
\mathrm{C} / \mathrm{E}\end{array}$} & \multirow{3}{*}{$\begin{array}{c}\text { MEAN C/E } \\
(S . D .)\end{array}$} & \multicolumn{2}{|c|}{ CORRECTIONS A } & \multirow{3}{*}{$\begin{array}{l}\text { CORRECTED } \\
\text { C/E }\end{array}$} & \multirow{3}{*}{$\begin{array}{c}\text { MEAN C/E } \\
(S . D .)\end{array}$} \\
\hline & & & & & --- & $-\infty$ & & \\
\hline & & & & & MESH & S4 & & \\
\hline$-\infty-\infty-\infty$ & --- & $\cdots-\infty$ & $-\cdots--$ & ----- & ---- & $-\infty-$ & ------ & ------ \\
\hline 14749 & CB & 0.6268 & 1.050 & & 1.010 & 0.966 & 1.025 & \\
\hline $147 \quad 48$ & $C B$ & 0.6521 & 1.041 & & 1.009 & 0.967 & 1.016 & \\
\hline $148 \quad 47$ & $\mathrm{CB}$ & 0.6649 & 1.053 & & 1.009 & 0.968 & 1.028 & \\
\hline $148 \quad 46$ & $C B$ & 0.7207 & 1.049 & & 1.007 & 0.970 & 1.025 & \\
\hline $148 \quad 45$ & $C B$ & 0.7739 & 1.057 & 1.050 & 1.005 & 0.976 & 1.036 & 1.027 \\
\hline $148 \quad 44$ & $\mathrm{CB}$ & 0.8217 & 1.051 & $(0.005)$ & 1.003 & 0.980 & 1.034 & $(0.007)$ \\
\hline 14744 & $F 1 S$ & 0.8763 & 1.034 & & 1.003 & 0.986 & 1.023 & \\
\hline $147 \quad 43$ & F1 & 0.8544 & 1.067 & & 1.005 & 0.993 & 1.065 & \\
\hline 14741 & Fl & 0.9277 & 1.060 & 1.052 & 1.006 & 0.991 & 1.056 & 1.045 \\
\hline 14740 & $\mathrm{~F} 1 \mathrm{~S}$ & 1.0090 & 1.048 & $(0.014)$ & 1.004 & 0.984 & 1.035 & $(0.019)$ \\
\hline $147 \quad 39$ & BI & 1.0130 & 1.046 & & 1.004 & 0.975 & 1.024 & \\
\hline $147 \quad 38$ & Bl & 1.0330 & 1.055 & 1.053 & 1.004 & 0.975 & 1.032 & 1.032 \\
\hline $147 \quad 37$ & Bl & 1.0330 & 1.059 & $(0.007)$ & 1.003 & 0.980 & 1.040 & $(0.008)$ \\
\hline 14736 & F2 & 1.0250 & 1.086 & & 1.005 & 0.992 & 1.083 & \\
\hline 14735 & F2 s & 1.0560 & 1.060 & & 1.001 & 0.993 & 1.053 & \\
\hline $147 \quad 34$ & F2 & 1.0120 & 1.094 & 1.080 & 1.004 & 0.995 & 1.092 & 1.074 \\
\hline 14733 & F2 S & 1.0500 & 1.078 & $(0.015)$ & 1.003 & 0.988 & 1.068 & $(0.017)$ \\
\hline $147 \quad 32$ & B2 & 1.0210 & 1.079 & & 1.002 & 0.978 & 1.058 & \\
\hline $147 \quad 31$ & B2 & 1.0050 & 1.083 & 1.085 & 1.003 & 0.976 & 1.060 & 1.064 \\
\hline 14730 & B2 & 0.9617 & 1.093 & $(0.007)$ & 1.000 & 0.982 & 1.074 & $(0.009)$ \\
\hline $147 \quad 29$ & F 3 & 0.9143 & 1.117 & & 1.003 & 0.995 & 1.115 & \\
\hline 14728 & E3 s & 0.8874 & 1.089 & & 0.997 & 1.000 & 1.086 & \\
\hline 14726 & E3 $\mathrm{s}$ & 0.7578 & 1.099 & & 0.995 & 1.002 & 1.096 & \\
\hline 14725 & F3 & 0.6627 & 1.135 & 1.110 & 0.999 & 1.002 & 1.136 & 1.106 \\
\hline 14724 & F3 S & 0.6026 & 1.109 & $(0.018)$ & 0.997 & 0.993 & 1.098 & $(0.020)$ \\
\hline 14723 & RB & 0.4870 & 1.125 & & 0.999 & 0.981 & 1.103 & \\
\hline 14722 & RB & 0.3947 & 1.116 & & 1.002 & 0.976 & 1.091 & \\
\hline $147 \quad 21$ & RB & 0.3114 & 1.109 & 1.110 & 1.005 & 0.974 & 1.086 & 1.088 \\
\hline 14720 & $\mathrm{RB}$ & 0.2540 & 1.088 & $(0.016)$ & 1.009 & 0.977 & 1.073 & $(0.012)$ \\
\hline
\end{tabular}

A CORRECTIONS WERE NOT CALCULATED IN POSITIONS 147-42 AND 147-27. 
TABLE 5.19. ZPPR-13A: TRANSPORT CORRECTED REACTION RATES FOR 238U $(\mathrm{N}, \mathrm{E})$

\begin{tabular}{|c|c|c|c|c|c|c|c|c|}
\hline \multirow{3}{*}{$\begin{array}{l}\text { MATRIX } \\
\text { POSITION }\end{array}$} & \multirow{3}{*}{ ZONE } & \multirow[b]{3}{*}{ EXP. } & \multirow{3}{*}{$\begin{array}{c}\text { REFERENCE } \\
\mathrm{C} / \mathrm{E}\end{array}$} & \multirow{3}{*}{$\begin{array}{l}\text { MEAN C/E } \\
\text { (S.D.) }\end{array}$} & \multicolumn{2}{|c|}{ CORRECTIONS A } & \multirow{3}{*}{$\begin{array}{l}\text { CORRECTED } \\
\text { C/E }\end{array}$} & \multirow{3}{*}{$\begin{array}{c}\text { MEAN C/E } \\
(S . D .)\end{array}$} \\
\hline & & & & & \multicolumn{2}{|c|}{ - } & & \\
\hline & & & & & MESH & S4 & & \\
\hline$-\infty-\infty-\infty$ & --- & $-\infty--$ & $-\cdots--$ & -ー-ー-ー- & $-\cdots$ & ---- & $-\cdots--$ & - - - \\
\hline 14749 & $\mathrm{CB}$ & 0.0220 & 0.883 & & 1.009 & 0.981 & 0.874 & \\
\hline 14748 & $\mathrm{CB}$ & 0.0255 & 0.897 & & 1.010 & 0.935 & 0.847 & \\
\hline $148 \quad 47$ & $\mathrm{CB}$ & 0.0289 & 0.919 & & 1.014 & 0.940 & 0.876 & \\
\hline $148 \quad 46$ & $C B$ & 0.0378 & 1.065 & & 1.021 & 0.866 & 0.942 & \\
\hline 14845 & CB & 0.0612 & 1.052 & 0.977 & 1.027 & 0.900 & 0.972 & 0.911 \\
\hline $148 \quad 44$ & CB & 0.1006 & 1.045 & $(0.086)$ & 1.010 & 0.904 & 0.954 & $(0.051)$ \\
\hline $147 \quad 44$ & FI S & 0.1421 & 0.948 & & 1.001 & 0.997 & 0.946 & \\
\hline $147 \quad 43$ & F1 & 0.2089 & 0.895 & & 0.989 & 1.036 & 0.917 & \\
\hline 14741 & F1 & 0.2250 & 0.893 & 0.912 & 0.993 & 1.040 & 0.922 & 0.925 \\
\hline $147 \quad 40$ & F1S & 0.1666 & 0.911 & $(0.025)$ & 1.006 & 0.997 & 0.914 & $(0.015)$ \\
\hline $147 \quad 39$ & B1 & 0.0951 & 1.054 & & 1.034 & 0.881 & 0.960 & \\
\hline 14738 & $\mathrm{Bl}$ & 0.0910 & 1.072 & 1.059 & 1.035 & 0.875 & 0.971 & 0.971 \\
\hline 14737 & $\mathrm{Bl}$ & 0.1267 & 1.050 & $(0.012)$ & 1.021 & 0.917 & 0.983 & $(0.012)$ \\
\hline 14736 & F2 & 0.2419 & 0.884 & & 0.992 & 1.036 & 0.909 & \\
\hline 14735 & F2 $\mathrm{S}$ & 0.2397 & 0.946 & & 1.005 & 1.024 & 0.974 & \\
\hline 14734 & F2 & 0.2618 & 0.919 & 0.920 & 0.995 & 1.046 & 0.957 & 0.942 \\
\hline 14733 & F2 $\mathrm{s}$ & 0.2020 & 0.931 & $(0.026)$ & 0.997 & 0.998 & 0.927 & $(0.029)$ \\
\hline $147 \quad 32$ & B2 & 0.1102 & 1.045 & & 1.037 & 0.904 & 0.980 & \\
\hline 14731 & B2 & 0.0846 & 1.118 & 1.090 & 1.029 & 0.843 & 0.970 & 0.992 \\
\hline 14730 & B2 & 0.1028 & 1.106 & $(0.039)$ & 1.028 & 0.903 & 1.027 & $(0.030)$ \\
\hline 14729 & F3 & 0.2050 & 0.919 & & 0.987 & 1.026 & 0.931 & \\
\hline 14728 & F3 $\mathrm{S}$ & 0.1988 & 1.032 & & 1.000 & 1.015 & 1.047 & \\
\hline 14726 & F3 $\mathrm{S}$ & 0.1838 & 1.030 & & 1.002 & 1.000 & 1.032 & \\
\hline 14725 & F 3 & 0.1773 & 0.977 & 0.987 & 0.991 & 1.028 & 0.995 & 0.997 \\
\hline 14724 & F3 $\mathrm{s}$ & 0.1125 & 0.979 & $(0.047)$ & 0.998 & 1.002 & 0.979 & $(0.046)$ \\
\hline $147 \quad 23$ & RB & 0.0493 & 1.112 & & 1.022 & 0.893 & 1.015 & \\
\hline 14722 & $\mathbf{R B}$ & 0.0262 & 1.049 & & 1.011 & 0.853 & 0.905 & \\
\hline 14721 & $R B$ & 0.0141 & 1.004 & 1.029 & 1.000 & 0.922 & 0.926 & 0.945 \\
\hline 14720 & $\mathrm{RB}$ & 0.0079 & 0.952 & $(0.068)$ & 0.986 & 0.994 & 0.933 & $(0.048)$ \\
\hline
\end{tabular}

A CURRECTIONS WERE NOT CALCULATED IN POSITIONS 147-42 AND 147-27. 
6.0 ANALYSIS OF CONTROL ROD WORTHS

The initial calculations of control rod worths used homogeneous atomic densities for each cell type and $B_{\text {eff }}$ values calculated with rz reactor models. These data are recorded in the monthly ZPR-TM reports. The analysis for $2 P P R-13 \mathrm{~A}$ has now been improved in several respects:

(i) Corrections for variations in drawer loadings as described in Section 3.5 .

(ii) Use of Beff results from xyz calculations.

(iii) Revisions to experimental results following improvements to the effective source ratio in the McCRUNCH code (Section 2.3.4).

This section gives an analys is of all results in $2 P P R-13 A$ together with transport-corrected values for rod banks.

The experimental control rods occupied four ZPPR matrix positions in which the drawers were filled with both $\mathrm{clad}$ and unclad natural $\mathrm{B}_{4} \mathrm{C}$ platelets for the first $457 \mathrm{~mm}$ (core region) and with sodium-filled plates for the second 457 (axial blanket region). Control rod position (CRP) drawers were filled with sodium-containing plates over their $914 \mathrm{~mm}$ length.
All control rod worths
were measured relative

to fuel. A number of measurements of the worths of CRPs relative to fuel were made in $13 \mathrm{~A}$ both for single positions and for banks. 
(v) The mean C/E for the 12 rods in FR2 (1.008) agrees well with the C/E for the banic of rods (1.010) which was measured at 20 s subcritical. Similarly the mean C/E for 12 rods in FR3 (1.038) compares with a C/E of 1.044 for the rod bank.

(vi) Control rod 13', which was adjacent to the blanket in FR2, has a worth lower than for $C R 13$, by $5 \%$, but the $C / E$ results agree within $0.1 \%$.

(vii) A remarkable discrepancy of $4 \%$ exists between predictions for rod 25 on the $x$-axis in FR3 and rod 28 on the $y$-axis. About $1 \%$ of this difference may be attributed to the ZPPR interface variation. The AMM model produced some improvement-from a $6 \%$ difference to a $4 \%$ difference.

(viii) The single rod measurements that were repeated in the second series, CR13, CR25 and CR28 gave worths that were higher than in the first measurements by $0.7 \%, 0.4 \%$ and $1.2 \%$ respectively. Comparison of the two subcritical references shows a difference of $2 k$ after adjustment for relative $241 \mathrm{Pu}$ decay, interface separation and temperature. Thus an uncertainty of about $1 \%$ is apparent due to unknown changes in core configuration (piece positioning in drawers and precise drawer positioning in matrix). 


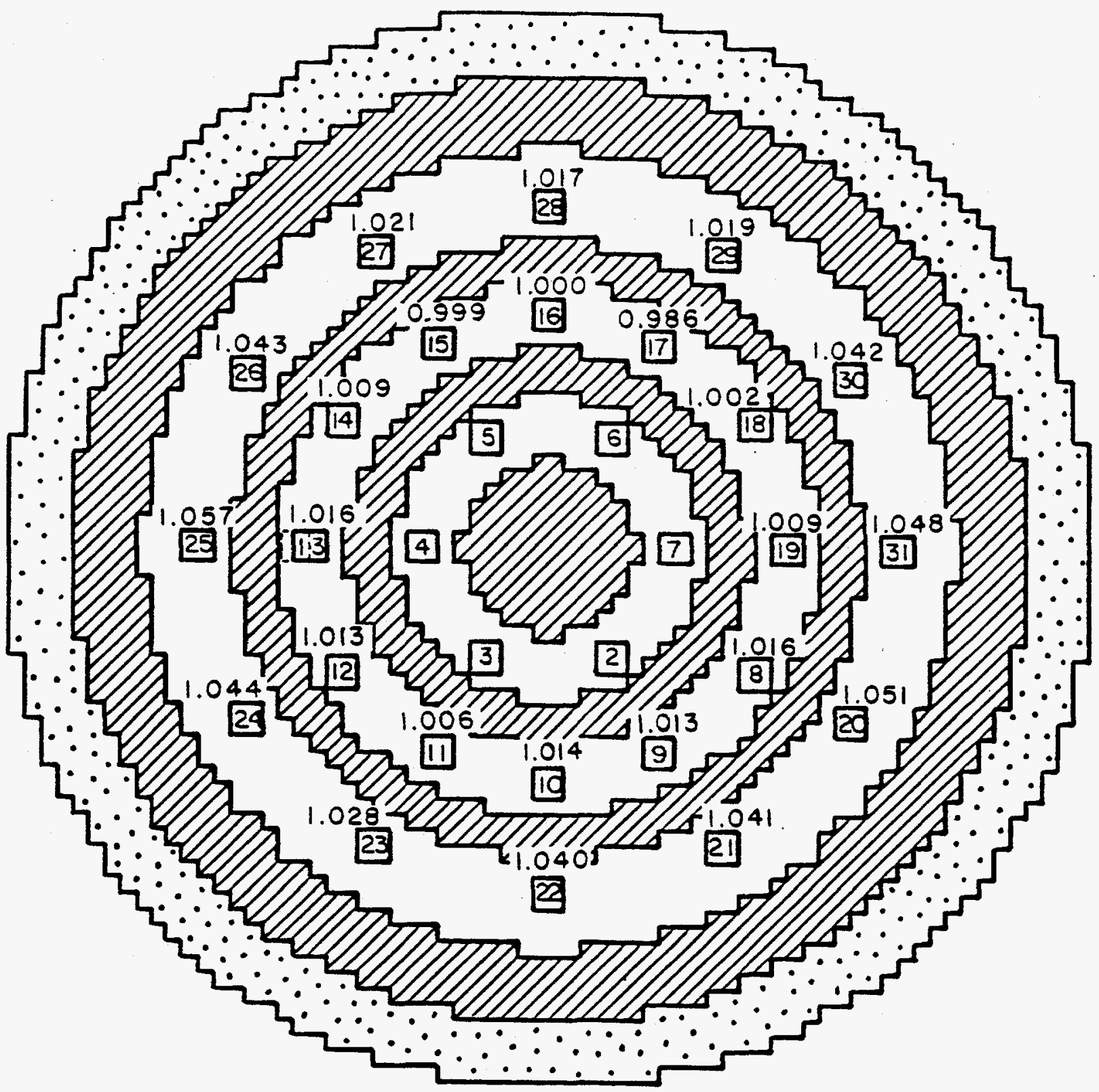

\# CONTROL ROO POSITION

$\therefore$ REFLECTOR

BLANKET

i.j ALTERNATE CRP

Fig. 6.1. Rod locations and $\mathrm{C} / \mathrm{E}$ values for the worths of individual rods in $2 P P R-13 A$. 
TABLE 6.1. 2PPR-13A Comparison of $x y z$ and $x y$ Calculations for Control Rod Worths

Number

Case

Re ference

12 CRP in $F 2$

$12 \mathrm{CR}$ in $\mathrm{F} 2$

Reference ${ }^{a}$

12 CRP in $F 2^{a}$

$12 \mathrm{CR}$ in $\mathrm{F} 2^{\mathrm{a}}$

Reference $e^{b}$

$12 \mathrm{CR}$ in $\mathrm{F} 2^{\mathrm{b}}$

$6 \mathrm{CR}$ in $\mathrm{Fl}$

$6 \mathrm{CR}$ in $\mathrm{F} 1^{\mathrm{C}}$

$12 \mathrm{CR}$ in $\mathrm{F} 3$

$12 \mathrm{CR}$ in $\mathrm{F} 3 \mathrm{C}$

Geometry

\begin{abstract}
28
\end{abstract}
28

28

$x y z$

xyz

xyz

xyz

xyz

xy

$x y$

$x y$

xyz

$x y$

xyz

$x y$
$12 \mathrm{CRP}$ in $\mathrm{F}^{\mathrm{b}} \mathrm{b}$
Worth Relative

Error ind

of Groups k-effective

0.978324

0.958703

0.919767

0.979818

0.960103

0.920769

0.979760

0.959992

0.920399

0.961163

0.962359

0.936091

0.936857

\section{to Reference, $\$$}

Worth, \%
The 8 group xyz calculations used data collapsed for the reference $x y z$ model in all zones except CRs and CRPs.

${ }^{b}$ The 8 group $x y$ calculations used bucklings derived from the reference xyz model in all zones except CRs and CRPs.

cThese calculations used the data generated for CRs in fuel zone 2 (F2).

dError in worth relative to xyz calculation in 28 groups.

File MR-A 25 
TABLE 6.2. Control Rod Worth Analysis for the First Series of Measurements in $2 P$ P $-13 \mathrm{~A}$

\begin{tabular}{|c|c|c|c|c|c|}
\hline Rods Inserted & $k_{e} f f^{a}$ & $\begin{array}{l}\text { Calcul ated } \\
\text { Worth, } \$^{b} \\
\end{array}$ & $\begin{array}{c}\text { AMM } \\
\text { Correctionc }\end{array}$ & $\begin{array}{c}\text { Measured } \\
\text { Worth (E), \$ } \\
\end{array}$ & $\begin{array}{c}\text { Corrected } \\
\text { C/E }\end{array}$ \\
\hline \multicolumn{6}{|l|}{ Fuel Ring 1} \\
\hline $\begin{array}{l}\text { CR04 } \\
6 \text { CRs }\end{array}$ & $\begin{array}{l}0.976385 \\
0.962359\end{array}$ & $\begin{array}{l}1.071 \\
5.603\end{array}$ & $\begin{array}{l}1.010 \\
1.009\end{array}$ & $\begin{array}{l}1.097 \\
5.725\end{array}$ & $\begin{array}{l}0.986 \\
0.987\end{array}$ \\
\hline \multicolumn{6}{|l|}{ Fuel Ring 2} \\
\hline $\begin{array}{l}\text { CR } 13 \\
C R 13^{\prime} \\
12 \mathrm{CRs} \\
6 \mathrm{CRs}+6 \mathrm{CRPs} \\
5 \mathrm{CRs}+7 \mathrm{CRPs}\end{array}$ & $\begin{array}{l}0.975954 \\
0.976142 \\
0.972077 \\
0.938122 \\
0.943729\end{array}$ & $\begin{array}{r}1.208 \\
1.149 \\
19.984 \\
13.753 \\
11.830\end{array}$ & $\begin{array}{l}0.996 \\
0.994 \\
1.0144 \\
1.0114 \\
1.014\end{array}$ & $\begin{array}{r}1.176 \\
1.118 \\
19.869 \\
13.428 \\
11.522\end{array}$ & $\begin{array}{l}1.023 \\
1.022 \\
1.010 \\
1.028 \\
1.031\end{array}$ \\
\hline \multicolumn{6}{|l|}{ Fuel Ring 3} \\
\hline $\begin{array}{l}\text { CR25 } \\
\text { CR28 } \\
6 \mathrm{CRs} \\
12 \mathrm{CRs} \\
6 \mathrm{CRs}+6 \mathrm{CRPs} \\
5 \mathrm{CRs}+7 \mathrm{CRPs} \\
\end{array}$ & $\begin{array}{l}0.977044 \\
0.977303 \\
0.956800 \\
0.936857 \\
0.949957 \\
0.953322 \\
\end{array}$ & $\begin{array}{r}0.861 \\
0.779 \\
7.436 \\
14.190 \\
9.721 \\
8.593 \\
\end{array}$ & $\begin{array}{l}0.981 \\
1.000 \\
0.997 \\
0.998 \\
0.998 \\
0.998 \\
\end{array}$ & $\begin{array}{r}0.796 \\
0.757 \\
7.082 \\
13.559 \\
9.095 \\
7.980 \\
\end{array}$ & $\begin{array}{l}1.062 \\
1.029 \\
1.047 \\
1.044 \\
1.067 \\
1.075 \\
\end{array}$ \\
\hline
\end{tabular}

${ }^{a}$ Calculation 8G XY DT IMPD WBD. keff for the reference subcritical core was 0.979760 .

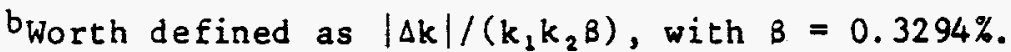

$c$ Correction for All-master model.

JAIIB 14 
TABLE 6.3. Worths of CRPs Relative to Fuel for the First Series of Measurements in $2 P P R-13 \mathrm{~A}$

\begin{tabular}{|c|c|c|c|c|c|}
\hline CRPs Inserted & $k_{e} f f^{a}$ & $\begin{array}{l}\text { Calcul ated } \\
\text { Worth, } \$^{b}\end{array}$ & $\begin{array}{c}\text { AMM } \\
\text { Correction }\end{array}$ & $\begin{array}{l}\text { Me asured } \\
\text { Worth }(E), \$\end{array}$ & $\begin{array}{c}\text { Corrected } \\
\text { C/E }\end{array}$ \\
\hline l.Ring 1 & & & & & \\
\hline $\begin{array}{l}\text { CRP0 } 4 \\
6 \text { CRPs }\end{array}$ & $\begin{array}{l}0.978483 \\
0.973041\end{array}$ & $\begin{array}{l}0.404 \\
2.140\end{array}$ & $\begin{array}{l}1.010 \\
1.009\end{array}$ & $\begin{array}{l}0.382 \\
2.013\end{array}$ & $\begin{array}{l}1.069 \\
1.072\end{array}$ \\
\hline
\end{tabular}

Fuel Ring 2

$\begin{array}{llllll}\text { CRP13 } & 0.978145 & 0.512 & 0.996 & 0.449 & 1.135 \\ \text { CRP13, } & 0.978188 & 0.498 & 0.994 & 0.449 & 1.103 \\ 12 \text { CRPs } & 0.959992 & 6.381 & 1.004 & 5.739 & 1.116\end{array}$

Fuel Ring 3

\begin{tabular}{llllll} 
CRP25 & 0.978566 & 0.378 & 0.981 & 0.313 & 1.185 \\
12 CRPs & 0.965200 & 4.674 & 0.998 & 4.079 & 1.144 \\
\hline
\end{tabular}

${ }^{a}$ Calculation 8G XY DT IMPD WBD. keff for the reference subcritical core was 0.979760 .

bWorth defined as $|\Delta k| /\left(k_{1} k_{2} B\right)$, with $B=0.3294 \%$.

${ }^{c}$ Correction for Al $l$-master model. 
TABLE 6.4 Single Control Rod Worths for the Second Series of Measurements in $Z P P R-13 \mathrm{~A}$

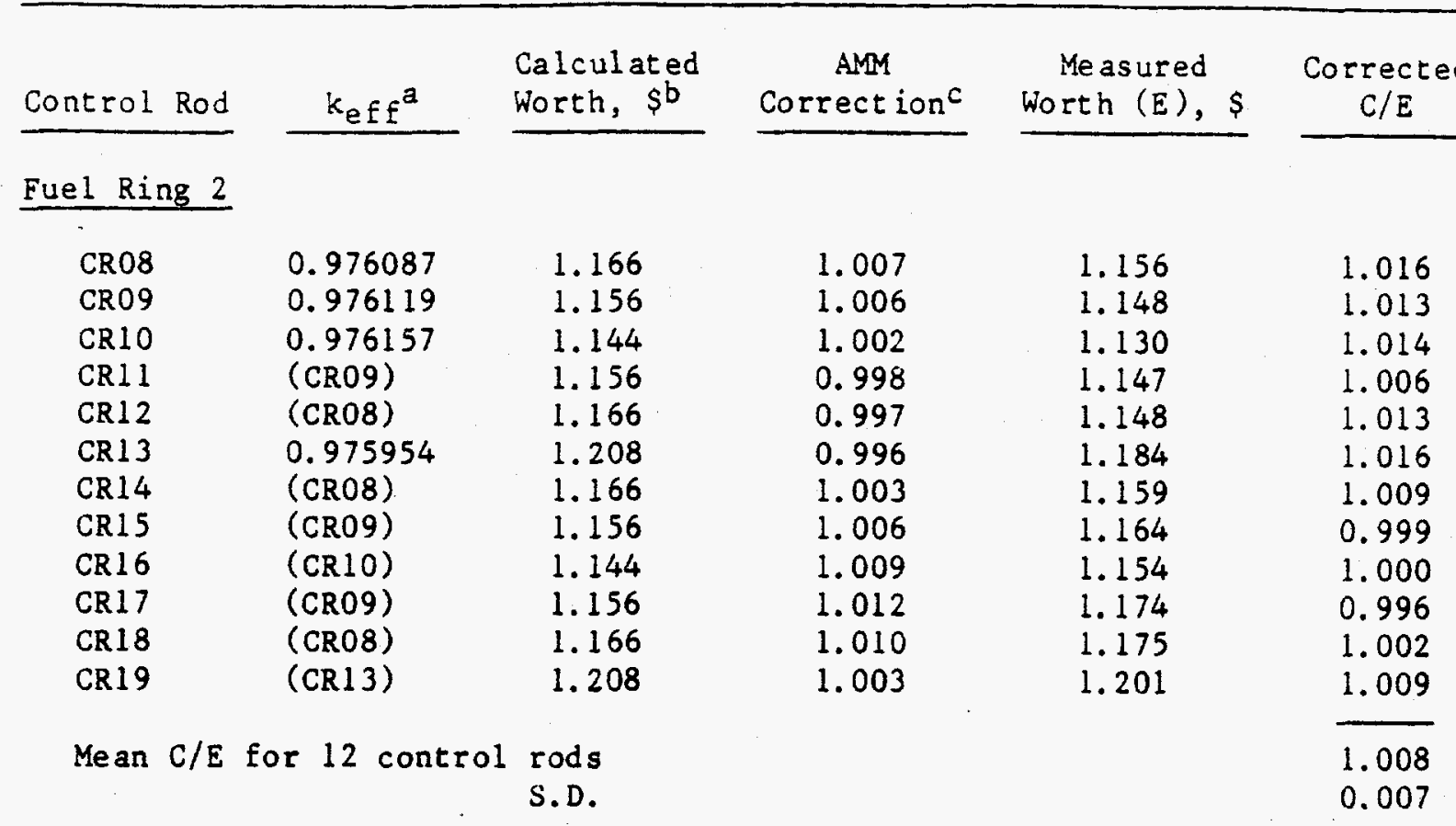

Fue 1 Ring 3

$\begin{array}{llllll}\text { CR20 } & 0.977139 & 0.831 & 1.004 & 0.794 & 1.051 \\ \text { CR21 } & 0.977233 & 0.801 & 1.006 & 0.774 & 1.041 \\ \text { CR22 } & 0.977303 & 0.779 & 0.995 & 0.745 & 1.040 \\ \text { CR23 } & (\text { CR21) } & 0.801 & 0.991 & 0.772 & 1.028 \\ \text { CR24 } & \text { (CR20) } & 0.831 & 0.991 & 0.789 & 1.044 \\ \text { CR25 } & 0.977044 & 0.861 & 0.981 & 0.799 & 1.057 \\ \text { CR26 } & \text { (CR20) } & 0.831 & 0.997 & 0.794 & 1.043 \\ \text { CR27 } & \text { (CR21) } & 0.801 & 1.001 & 0.785 & 1.021 \\ \text { CR28 } & \text { (CR22) } & 0.779 & 1.000 & 0.766 & 1.017 \\ \text { CR29 } & \text { (CR21) } & 0.801 & 1.011 & 0.795 & 1.019 \\ \text { CR30 } & \text { (CR20) } & 0.831 & 1.004 & 0.801 & 1.042 \\ \text { CR31 } & \text { (CR25) } & 0.861 & 0.990 & 0.813 & 1.048 \\ \text { (C) } & & & & 1.038 \\ \end{array}$

acalculation 8G XY DT IMPD WBD. keff for the reference subcritical core was 0.979760 .

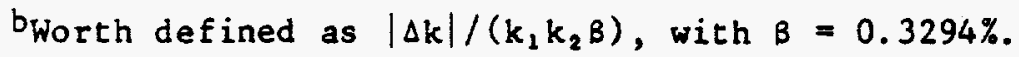

$c^{c}$ Correction for Al 1 -master model. 
TABLE 6.5. Comparison of C/E Results for Single Control Rods in Left and Right Sides of $2 P P R-13 \mathrm{~A}$

\begin{tabular}{|c|c|c|c|c|c|}
\hline \multirow[b]{2}{*}{ Rod Pair } & \multicolumn{5}{|c|}{ Ratio of $\mathrm{C} / \mathrm{E}$ on RHS to $\mathrm{C} / \mathrm{E}$ on LHS } \\
\hline & Reference & Model & Narrow Drawers & $\begin{array}{r}\text { Narrow Drawers } \\
+ \text { Blanket Detectors } \\
\end{array}$ & $\begin{array}{c}\text { All } \\
\text { Masters } \\
\end{array}$ \\
\hline \multicolumn{6}{|c|}{ Fuel Zone 2} \\
\hline $\begin{array}{l}15,17 \\
14,18 \\
13,19 \\
12,8 \\
11,9\end{array}$ & $\begin{array}{l}0.989 \\
0.984 \\
0.985 \\
0.993 \\
0.999\end{array}$ & & $\begin{array}{l}1.002 \\
1.003 \\
1.005 \\
1.012 \\
1.010\end{array}$ & $\begin{array}{l}0.996 \\
0.995 \\
0.992 \\
1.010 \\
1.008\end{array}$ & $\begin{array}{l}0.997 \\
0.993 \\
0.993 \\
1.003 \\
1.007\end{array}$ \\
\hline \multicolumn{6}{|c|}{ Fuel Zone 3} \\
\hline $\begin{array}{ll}27, & 29 \\
26, & 30 \\
25, & 31 \\
24, & 20 \\
23, & 21\end{array}$ & $\begin{array}{l}0.986 \\
0.990 \\
0.982 \\
0.992 \\
0.998 \\
\end{array}$ & & $\begin{array}{l}1.002 \\
1.011 \\
1.001 \\
1.013 \\
1.014\end{array}$ & $\begin{array}{l}0.996 \\
1.003 \\
0.995 \\
1.008 \\
1.010\end{array}$ & $\begin{array}{l}0.998 \\
0.999 \\
0.991 \\
1.007 \\
1.013 \\
\end{array}$ \\
\hline $\begin{array}{c}\text { Mean } \\
\sigma\end{array}$ & $\begin{array}{l}0.990 \\
0.006\end{array}$ & & $\begin{array}{l}1.007 \\
0.005\end{array}$ & $\begin{array}{l}1.001 \\
0.007\end{array}$ & $\begin{array}{l}1.000 \\
0.007\end{array}$ \\
\hline
\end{tabular}


TABLE 6.11. Comparison of Control Rod Worths in ZPPR-13A

\begin{tabular}{|c|c|c|c|c|}
\hline Control Rods & As sembly & $\begin{array}{l}\text { Me asured } \\
\text { Worth, } \$\end{array}$ & $C / E^{b}$ & $\begin{array}{l}\text { Change } \\
\text { in worth, \% }\end{array}$ \\
\hline
\end{tabular}

Fuel Ring 1
$6 \mathrm{CRs}^{\mathrm{a}}$
$13 \mathrm{~A}$
5.73
0.987
$--$

Fuel Ring 2

$\begin{array}{lllll}\text { CR } 16 & 13 \mathrm{~A} & 1.15 & 1.000 & =- \\ 12 \mathrm{CRs} & 13 \mathrm{~A} & 19.87 & 1.010 & --\end{array}$

Fuel Ring 3

$\begin{array}{lllll}\mathrm{CR} \mathrm{25} & 13 \mathrm{~A} & 0.798 & 1.060 \\ \mathrm{CR} 28^{\mathrm{C}} & 13 \mathrm{~A} & 0.762 & 1.0: 3 & - \\ 6 \mathrm{CRs} \text { (odd) } & 13 \mathrm{~A} & 7.08 & 1.047 & - \\ 6 \mathrm{CRs} \text { (even) } & & & \\ 12 \mathrm{CRs} & 13 \mathrm{~A} & 13.56 & 1.044\end{array}$

The inner ring rods were rotated by $30^{\circ}$ in $2 P P R-13 \mathrm{~B} / 1$ relative to $Z P P R-13 A$ to al ign with blanket-ring gaps.

$b_{\text {Reference }}$ diffusion calculations, 8 groups, $x y$ geometry.

control rod 25 is on the $x$-axis and control rod 28 is on the $y$-axis (in 1 ine with blanket-ring gaps). These rods were measured twice in $Z P P R-13 A$ and the mean result is used. 


\subsection{Control Rod Interactions}

The worths of rod banks in $2 P P R-13 A$ are compared with the sums of the individual rod worths in Table 6.12. The normalized interaction obtained by dividing by the average of the single rod worths is useful for comparison between different rings and between different cores. The normalized interaction of $37 \% / \$$ in FR2 is we 11 predicted. Interaction of $56 \% / \$$ for 12 rods in FR3 and of $63 \% / \$$ for 6 rods in FR3 are overpredicted by $2 \%$ and $3 \%$. 
TABLE 6.12. Control Rod Interaction Effects in 2PPR-13A

\begin{tabular}{|c|c|c|c|}
\hline \multirow{2}{*}{\multicolumn{4}{|c|}{ Euel Ring 2}} \\
\hline & & & \\
\hline $\begin{array}{l}\text { Worth of bank of } 12 \text { rods, } \$ \\
\text { Sum of individual rod worths, } \$ \\
\text { Interaction, } \% \\
\text { Normalized interaction, } \% / \$ b\end{array}$ & $\begin{array}{l}19.869 \\
13.940 \\
42.5 \\
36.6\end{array}$ & $\begin{array}{l}20.064 \\
14.049 \\
42.8 \\
36.6\end{array}$ & $\begin{array}{l}1.010 \\
1.008 \\
1.007\end{array}$ \\
\hline Fuel Ring 3 & & & \\
\hline $\begin{array}{l}\text { Worth of bank of } 12 \text { rods, } \$ \\
\text { Sum of ind ividual rod worths, } \$ \\
\text { Interaction, } \% \\
\text { Normal ized interaction, } \% / \$\end{array}$ & $\begin{array}{l}13.559 \\
9.427 \\
43.8 \\
55.8\end{array}$ & $\begin{array}{l}14.162 \\
9.783 \\
44.8 \\
54.9\end{array}$ & $\begin{array}{l}1.044 \\
1.038 \\
1.023\end{array}$ \\
\hline $\begin{array}{l}\text { Worth of bank of } 6 \text { rods, } \$ \\
\text { Sum of ind ividual rods, } \$ \\
\text { Interaction, } \% \\
\text { Normalized interaction, } \% / \$\end{array}$ & $\begin{array}{l}7.082 \\
4.738 \\
49.5 \\
62.7\end{array}$ & $\begin{array}{l}7.414 \\
4.908 \\
51.1 \\
62.4\end{array}$ & $\begin{array}{l}1.047 \\
1.036 \\
1.032\end{array}$ \\
\hline
\end{tabular}

The rod bank worths were measured in the first series and the individual rods in the second series. There are indications of a systematic difference between the results from the two series of about $0.7 \%$ (see text).

busing the mean worth of a single rod in the bank. JAIIB25 


\subsection{Transport Calculations}

Transport calculations have been made for rod banks in each of the

three fuel $r$ ings in $2 P P R-13 A$

Transport calculations require a

finer mesh than the $55 \mathrm{~mm}$ (IMPD) used in the reference diffusion calculations.

The diffusion calculations were repeated with the number of mesh points doubled

(4MPD). Calculations were then made with the $S_{4}$ transport option of DIF3D.

Since the $\mathrm{S}_{4}$ calculations used isotropic diffusions (NBD), the diffusion theory calculations were also repeated with this method. Results of these calculations are shown in Table 6.15 :

For $2 P P R-13 A$ the effects of a finer mesh and higher order quadrature were investigated in a one-dimensional $r$ model using the 1DANT code. This model, shown schematically in Fig. 6.4, modelled control-rod banks as annular regions. The rod-bank worths do not match those of the xy model very closely, as shown in Table 6.18 , but transport corrections are similar. Table 6.19 shows the effects of $S_{16}$ quadrature and $f$ ine mesh which are less than $0.5 \%$.

The mesh and transport corrections are of opposite signs, but compensate one another to different degrees as a function of rod radius and blanket arrangement. In ZPPR-13A, the mesh and transport corrections increase the radial discrepancy between FRI and FR3 by $2 \%$,

Streaming effects are included in the reference calculations, but their effect can be seen from Table 6.15 These improve the results for the relat ive bank worths between FRI and FR3 by $2 \%$ in $13 \mathrm{~A}$

Table 6.20 show the corrected results for the rod banks. The tables include corrections to 28 group xyz calculations for Table. 6.14 to 15 . The following conclusions are noted:

(i) For ZPPR-13A the corrected C/E results are 0.980 (FR1), 1.011 (FR2) and 1.059 (FR3). The discrepancy between the inner and outer rod positions is $8 \%$. 



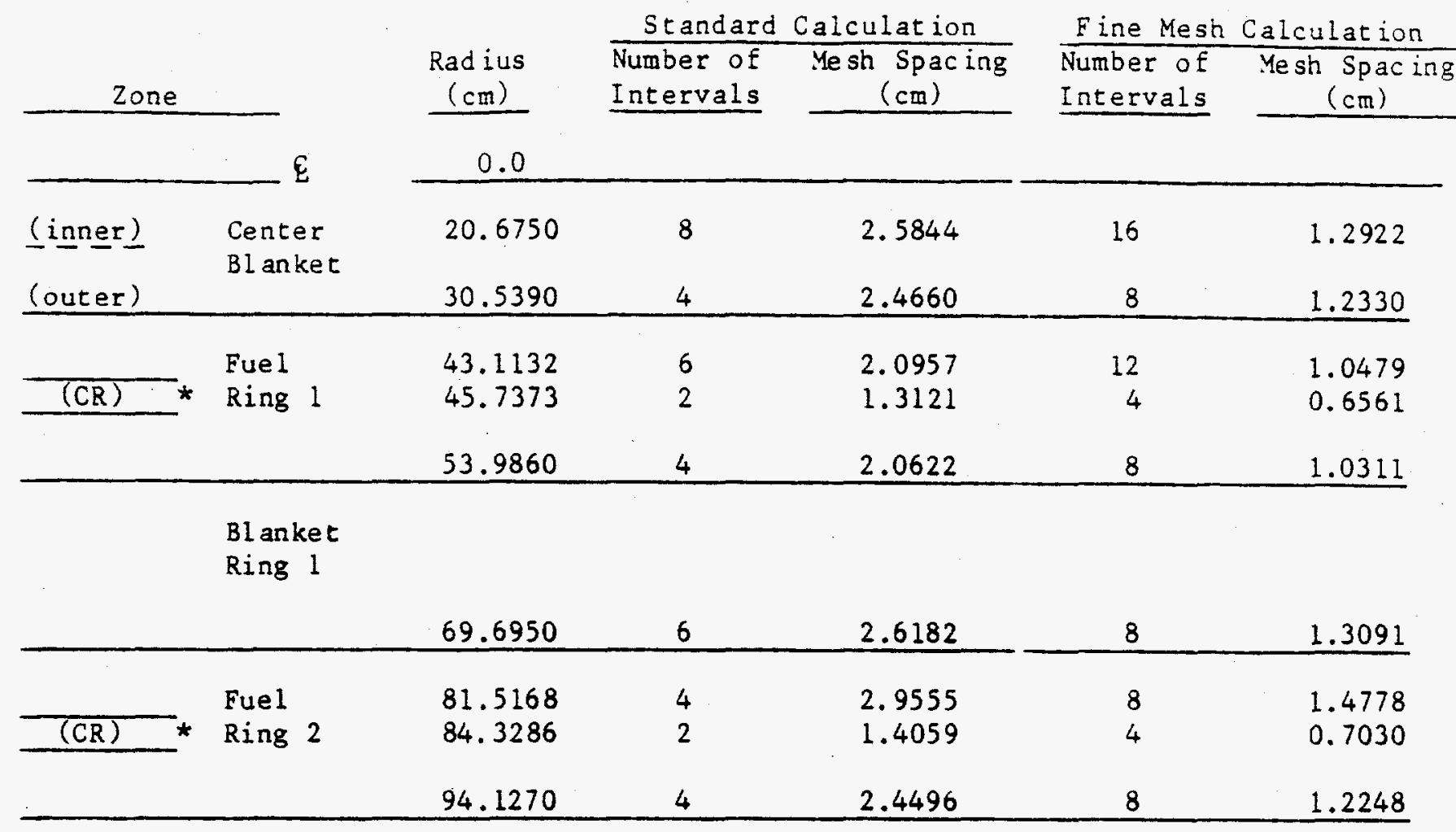

$B 1$ anke t

Ring 2

109.0460

6

2.4865

12

1.2433

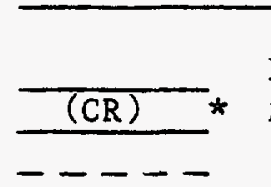

Fuel

120.4072

122. 3282

1.8935

0.9605

125.6060

1.6389

12

0.9468

Ring 3

141.0530

1.9309

0.4803

2

4

0.8195

(inner)

(inner)

Radial

$\mathrm{Bl}$ anket

154.7170

8

16

0.9655

(outer)

166.4540

6

2.2773

12

1.1387

6

2.2773

1.9562

12

0.9781

Radial

Reflector

189.4890 8

2.8794

16

1.4397

Matrix

$\frac{205.0}{(*)(\mathrm{CR}):}$ fuel, CR absorber or CRP compositions.

3.8778

8

1.9389

Fig. 6.4. One-dimensional Model for Study of Higher-order Transport Effects in ZPPR-13A. 
TABLE 6.15. ZPPR-13A: Comparison of Diffusion and Transport Calculations for Control Rod Worths

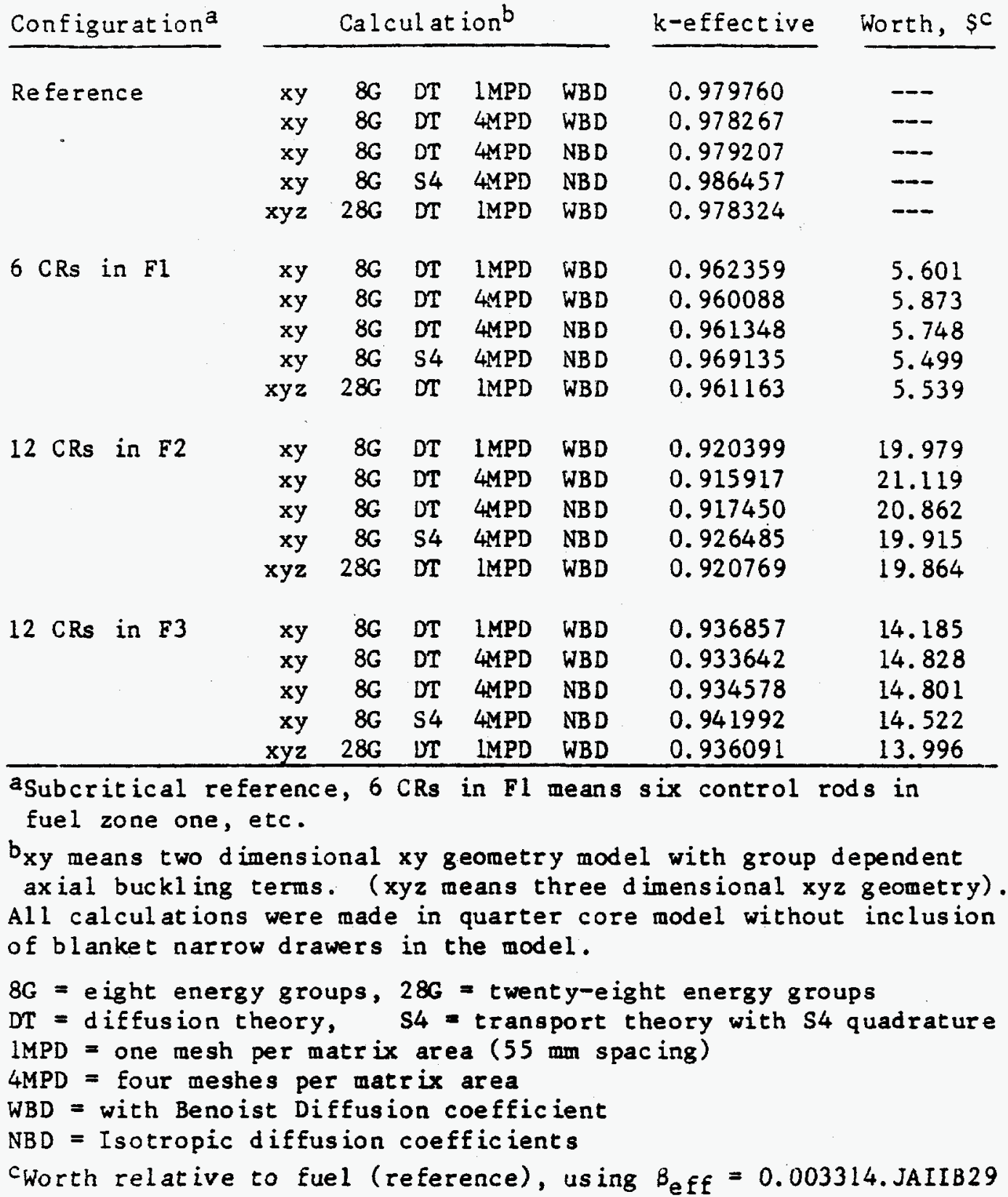


TABLE 6.18. Comparison of Transport Corrections in $x y$ and r-geonetry for 2PPR-13A Control Rod Banks

\begin{tabular}{|c|c|c|c|c|}
\hline \multirow[b]{2}{*}{ Rod Bank } & \multicolumn{2}{|c|}{ xy Model } & \multicolumn{2}{|c|}{ r Model } \\
\hline & $\begin{array}{c}\text { Transport }\left(\mathrm{S}_{4}\right) \\
\text { Worth, } \mathrm{S} \\
\end{array}$ & $\begin{array}{l}\text { Worth Ratioa } \\
\text { S4/DT } \\
\end{array}$ & $\begin{array}{r}\text { Transport }\left(\mathrm{S}_{4}\right) \\
\text { Worth, } \$ \\
\end{array}$ & $\begin{array}{c}\text { Worth Ratio a } \\
\text { S4/DT } \\
\end{array}$ \\
\hline $\begin{array}{rll}6 & \text { CRs } & F 1 \\
12 & \text { CRs } & F 2 \\
12 & \text { CRs } & \text { F } 3\end{array}$ & $\begin{array}{l}1.81 \\
6.56 \\
4.79\end{array}$ & $\begin{array}{l}0.955 \\
0.955 \\
0.981\end{array}$ & $\begin{array}{l}1.93 \\
7.26 \\
5.76\end{array}$ & $\begin{array}{l}0.968 \\
0.965 \\
0.979\end{array}$ \\
\hline
\end{tabular}

TABLE 6.19. Higher Order Quadrature and Fine Mesh Effects for Control Rod Worths in 2PPR-13A

\begin{tabular}{|c|c|c|c|}
\hline \multirow[b]{2}{*}{ Rod Bank } & \multicolumn{3}{|c|}{ Rat io of Worths } \\
\hline & $s_{16} / s_{4} a$ & $\begin{array}{l}\text { Fine Mesh/ } \\
\text { St and ard Me shb }\end{array}$ & $\begin{array}{l}\text { Combined } S_{16} \\
\text { and Fine Mesh }\end{array}$ \\
\hline $\begin{array}{rrr}6 & \text { CRs } & \text { F1 } \\
12 & \text { CRs } & \text { F2 } \\
12 & \text { CRs } & \text { F3 }\end{array}$ & $\begin{array}{l}0.998 \\
0.997 \\
0.996\end{array}$ & $\begin{array}{l}0.999 \\
0.997 \\
0.995 \\
\end{array}$ & $\begin{array}{l}0.997 \\
0.994 \\
0.991 \\
\end{array}$ \\
\hline $\begin{array}{l}\text { awith stan } \\
b_{\text {With }} s_{16}\end{array}$ & dratur & & MR2-A 22 \\
\hline
\end{tabular}


TABLE 6.20. The Effect of Calculational Improvements on Control Rod Worth $\mathrm{C} / \mathrm{E}$ Values in $2 \mathrm{PPR}-13 \mathrm{~A}$

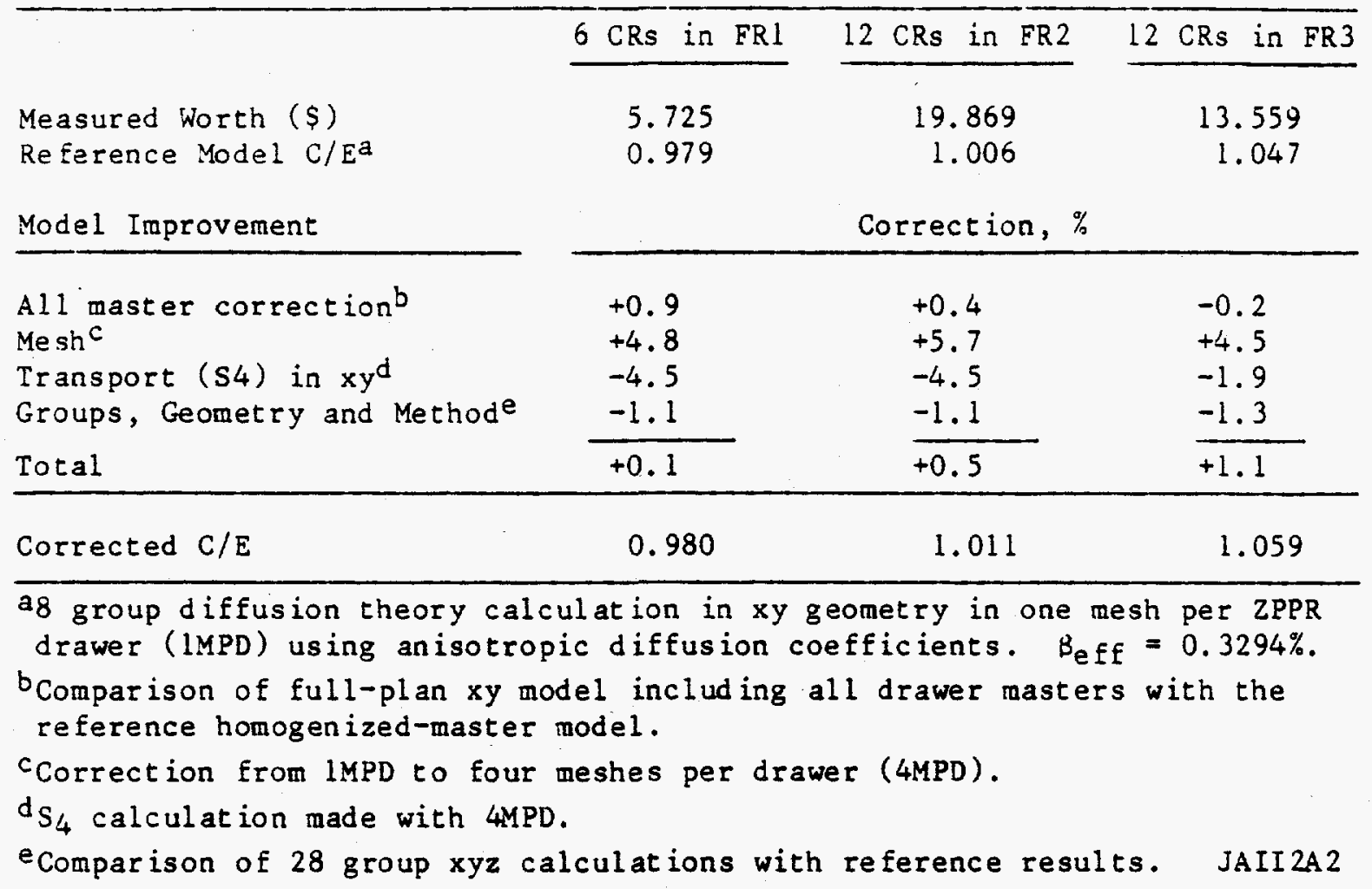




\subsection{SODIUM-VOID REACTIVITY}

Zone sodium-voiding experiments were done in phases $13 \mathrm{~A}$

\subsection{ZPPR-13A}

The ZPPR-13A sodiun-void experiments were designed principally to provide tests of calculated radial variations, which in the heterogeneous design include complex leakage effects between the fuel and blanket zones. Annular sectors in each fuel zone were voided of sodium over a length of $305 \mathrm{~mm}$ (12 in.) on each side of the midplane, with the outer fuel zone (F3) being voided in two radial segments. Symmetric void zones were introduced on each side of the core to permit analys is with a one-eighth core model of the assembly. The sectors in the inner fuel zone (F1) were voided in two steps, $\pm 203 \mathrm{~mm}$ ( $8 \mathrm{in.}$ ) and $+305 \mathrm{~mm}$ from the midplane. In addition, the entire fuel zone 1 was voided $( \pm 305 \mathrm{~mm})$ in order to compare with results from the sectors and also to permit analysis with an $\mathrm{rz}$ model for investigation of transport corrections. Following voiding of the fuel zones, contiguous sectors in the two internal blanket zones were voided over a height of $\pm 203 \mathrm{~mm}$. In the last step in the series, sodium

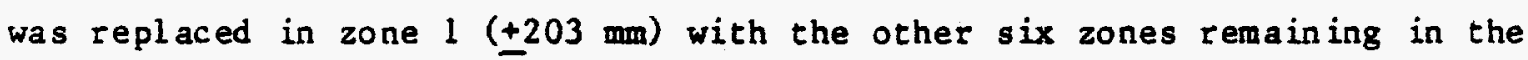
voided condition. This experiment has been variously described as an "inverse voiding" or a "reflood".

The reactor configuration at the start of the voiding sequence is shown in Fig. 7.1. This configuration differed from the reference critical configuration by the replacement of double-column fuel drawers with singlecolumn fuel drawers in locations $1,242-26 ; 1,255-26 ; 1,242-73 ; 1,255-73 ; 1,246-73$; $1,251-73 ; 1,246-26 ; 1,251-26 ; 1,245-56 ; 1,252-56 ; 1,245-43 ; 1,252-43 ; 1,242-43 ;$ $1,255-43 ; 1,242-56$; and $1,255-56$. Th is configuration was $81 k$ subcritical. 
In the first voiding step, sodiun was renoved from the first 8 in. of each half in zone 1 . In the second step, the axial half height of the void was increased to $12 \mathrm{in.}$. In all subsequent steps in fuel zones, the axial extent of the voids was $\pm 12 \mathrm{in.}$ In the blanket zones, the axial extent of the voids was \pm 8 in. Differences between the lengths of sodium-containing cans in the fuel and blanket regions prompted the decision to have the difference in the axial extent of the voids. All steps were cumulative.

The results of the various voiding steps are presented in Table 7.1 . All worth determinations were made using the 64 in-core fission counters and the subcritical-source-multipl ic at ion technique. The subcritical-sourcemultipl ication measurements were cal ibrated by making a rod-drop reactivity measurement after voiding zone 7 . With all seven zones voided, the reactor was $12 k$ subcritical.

There were only two reflood steps. In the first step sodium was added back \pm 8 in. in zone 1 . All the remaining sodium was added back in the second step and the final subcritical ity was $78 t$. There is a discrepancy of $3 k$ in subcritical ity between the nominally equivalent configurations before voiding and after reflooding. The source of this discrepancy is not presently known, but the values for the step worths shown in Table 7.1 should still be used as the experiment values.

The uncertainties in the cumulative worths and in the step worths given in Table 7.1 were obtained by combining a 0.26 random uncertainty in any reactivity difference due to temperature and table-closure corrections with a $0.8 \%$ correlated uncertainty due to detector cal ibration. The uncertainty in the step worth per $\mathrm{kg}$ sodiun removed was obtained from the uncertainty in the step worth and a $1 \%$ random uncertainty in sodium mass. Uncertainties due to counting statistics are very small compared to other uncertainties and are not included. 
The change in sceel mass was small for each step and its effect is included in the step worth.

The calculation methods used for analys is in $2 P P R-13 \mathrm{~A}$ are similar to those employed in previous calculations for heterogeneous cores. Processing of the ENDF/B-IV cross section for unit cell heterogeneity with the SDX code used impressed zone- and group-dependent bucklings which were obtained from the zone leakages in prior xyz calculations. For the reference core, these data were the same as those employed for the analys is of reaction rates described earlier. Cross sections for the voided cells were generated by the same method. The bucklings in this case were derived from a second xyz calculation in which all seven zones were voided. Separate macroscopic cross sections were thus produced for single-column and double-column fuel drawers in each of the three fuel zones. A single set of cross sections was used for the internal blanket zones.

An approximate treatment of streaming in the unit cells was included using the Benoist definition of anisotropic diffusion coefficients. Divergence of the diffusion coefficients in the voided region was avoided by smearing of the sodium plate claddings over the total plate thickness. This procedure is consistent with previous sodium-void analysis at ZPPR. However, in contrast to previous applications, for $2 P P R-13 A$ we have used the ratios $D$ (Benoist)/ $D$ (heterogeneous) as "diffusion coefficient modifiers" in the DIF 3D code. This procedure corrects for the prescription of diffusion coefficients for the heterogeneous cell that is used in the SDX code, in addition to treating platecell streaming effects. Previous calculations used the ratio $D$ (Benoist)/ $D$ (homogeneous) in order to provide numerical values for the streaming effects themselves. Test calculations were run for the combined voiding steps 1 and 2 and for step 5 in order to determine the effect of the change in the definition 
of the ratio. Negligible differences of less than $1 \%$ were Found for the void reactivities using different definitions, although the diffusion coefficient modifiers differ appreciably in some energy groups.

The calculated void reactivities were obtained with an exact perturbation method using an xyz model with 28 group data. Following a calculation of the real flux for the subcritical reference core, an adjoint calculation was made for each of the void steps that were measured. The traditional "nonleakage" and "leakage terms" were obtained using the VARI3D perturbation code. The worths, in dollars, were defined as $\Delta k /\left(k_{1} k_{2} \beta\right)$, where 1 and 2 refer to the reference and perturbed states, respectively. The value of $B_{\text {eff }}(0.3295 \%)$ was calculated using ENDF/B-V delayed neutron data and an $r z$ model of the reference core. In the experiments, the detector drawers and drawers opposite detectors were not voided of sodium. Due to the asymmetric location of the detectors, those drawers were voided in the calculational model. The calculated results are given in Table 7.2. When comparing the calculated vs. experimental results, this difference was taken into account by normalizing to the mass of sodium that was removed.

The calculated and measured results for the $Z P P R-13 A$ sodium-void experiments were processed through the same data analysis code that was used for previous experiments. (15) The calculated reactivity of each step was split into a negative and a positive term; i.e., the sum of the leakage components and the sum of the non-leakage (reaction) components. Through a non-linear fitting procedure, separate leakage and non-leakage bias factors and the ir covariance matrix were determined. These factors are 0.94 for both terms when only the core void steps are included. Including the blanket void steps reduces the factors to 0.92 . These are the factors by which one would multiply the leakage and non-leakage components of a calculated void reactivity in an LMFBR similar to $2 P P R-13 A$, in order to improve the reactivity prediction. 
The data were combined with data from smaller heterogeneous assemblies reported in Ref, 15 and the bias factors were re-fit. A leakage bias factor of 0.90 and a non-leakage bias factor of 0.94 were obtained. These are similar to the results reported in Ref. 15.

Table 7.3 compares the calculated ( $C$ ) and biased calculated (P) results with the measured results (E). Also given are the 10 uncertainties in the $P / E$ ratios, where the covariance in the bias factors makes the principal contribution. In the fitting process, it is assumed that the approximate calculation procedures introduce net errors that are random on average over many regions of the reactor. Starting with only the contribution from the experimental errors, the covariance natrix is adjusted until a $x^{2}$ test ind icates that a reasonable fit is obtained. Note that six of the $P / E$ values in Table 7.3 fall within $1 \sigma$ of 1.0 , and the other two values are within $2 \sigma$, even though the range of experimental results includes variations of more than an order of magnitude as well as a change in sign. Nevertheless, errors in the predictions are only about $6 \%$ for the major positive void steps. 



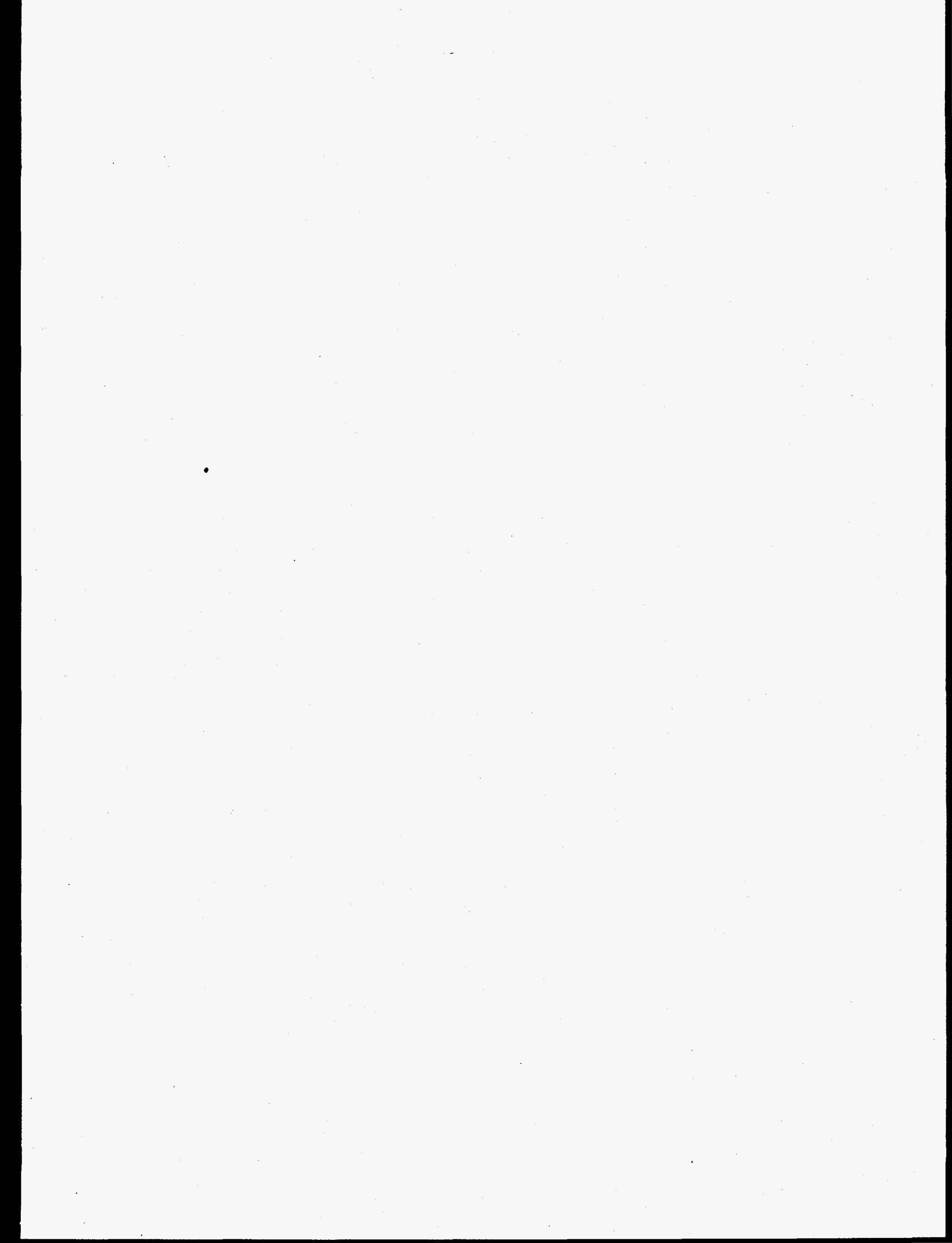




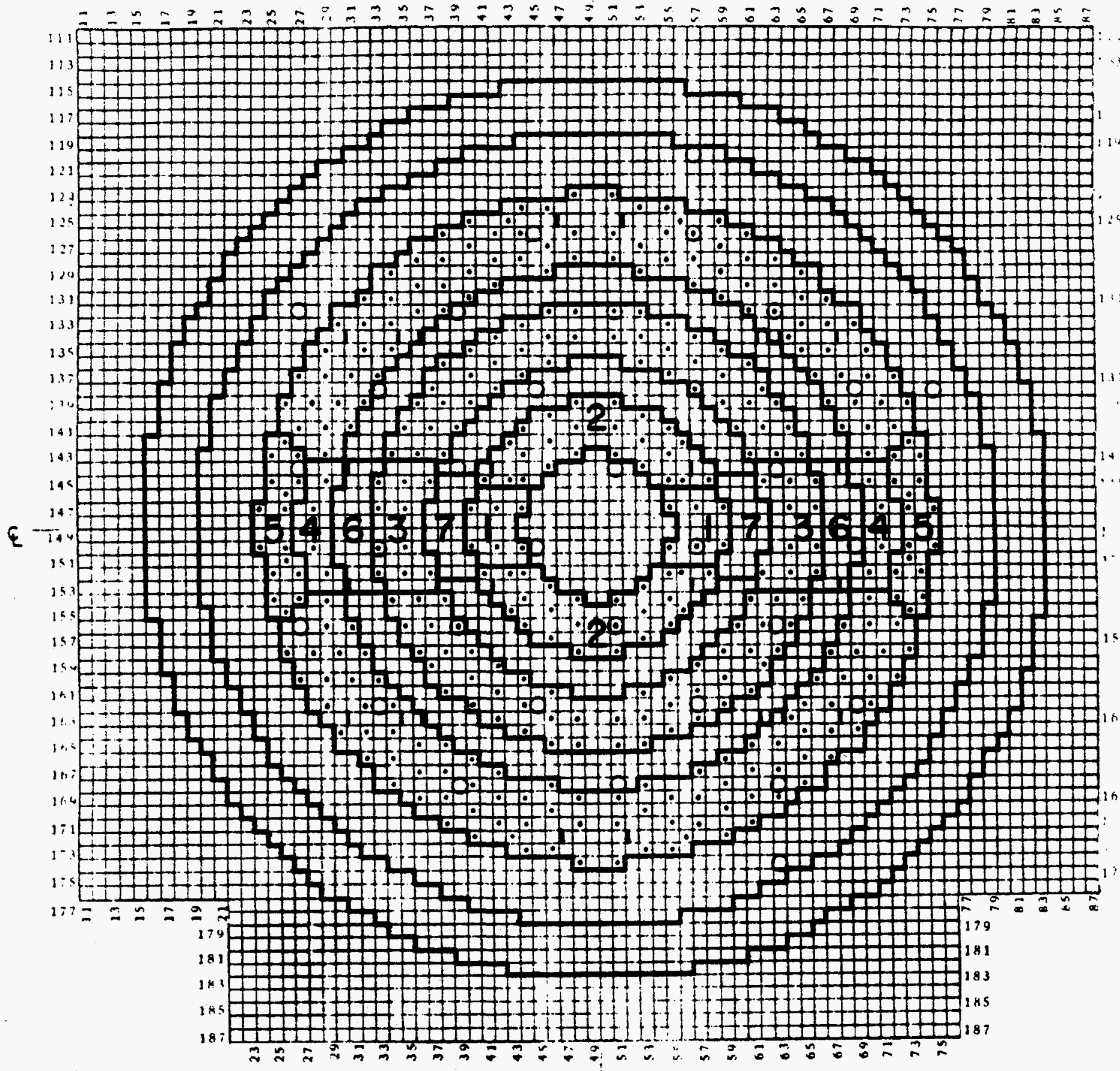

I PSR

O DETECTOR

- single column fuel

Fig. 7.1. Interface diagram showing the reference configuration for the sodium-voiding experiments and showing the voiding zones in ZPPR-13A. Ilalf 1 . 

TABLE 7.1.

\begin{tabular}{|c|c|c|c|c|c|c|}
\hline Zone & He ight, cm & $\begin{array}{l}\text { Mass of } \mathrm{Na} \\
\text { in St ep, } \mathrm{kg}\end{array}$ & $\begin{array}{c}\text { Mass of } \\
\text { Steel Added } \\
\text { in Step, kg }\end{array}$ & $\begin{array}{l}\text { Cumul at ive } \\
\text { Worth, }\end{array}$ & Step Worth, & $\begin{array}{l}\text { Step Worth, } \\
k / \mathrm{kg} \mathrm{Na}\end{array}$ \\
\hline $\begin{array}{l}1 \\
\text { void }\end{array}$ & \pm 20.3 & 21.82 & 0.26 & $7.06 \pm 0.21$ & $7.06 \pm 0.21$ & $0.324 \pm 0.010$ \\
\hline $\begin{array}{l}1 \\
\text { void }\end{array}$ & $\begin{array}{l} \pm 20.3- \\
\pm 30.5\end{array}$ & 10.65 & 0.27 & $7.68 \div 0.21$ & $0.62 \pm 0.20$ & $0.058 \pm 0.019$ \\
\hline $\begin{array}{l}2 \\
\text { void }\end{array}$ & \pm 30.5 & 93.46 & 1.23 & $35.75 \pm 0.35$ & $28.07 \pm 0.30$ & $0.300 \pm 0.004$ \\
\hline $\begin{array}{l}3 \\
\text { void }\end{array}$ & \pm 30.5 & 54.14 & 0.95 & $53.88 \pm 0.48$ & $18.13 \pm 0.25$ & $0.335 \pm 0.005$ \\
\hline $\begin{array}{l}4 \\
\text { void }\end{array}$ & \pm 30.5 & 34.28 & 0.70 & $63.36 \pm 0.54$ & $9.48 \pm 0.21$ & $0.276 \pm 0.007$ \\
\hline $\begin{array}{l}5 \\
\text { void }\end{array}$ & \pm 30.5 & 50.10 & 0.79 & $51.94 \pm 0.46$ & $-11.42 \pm 0.22$ & $-0.228 \pm 0.005$ \\
\hline $\begin{array}{l}6 \\
\text { void }\end{array}$ & \pm 20.3 & 10.85 & 0.20 & $61.18 \pm 0.53$ & $9.24 \pm 0.21$ & $0.852 \pm 0.020$ \\
\hline $\begin{array}{l}7 \\
\text { void }\end{array}$ & \pm 20.3 & 9.45 & 0.16 & $69.31 \pm 0.59$ & $8.13 \pm 0.21$ & $0.860 \pm 0.024$ \\
\hline$\stackrel{1}{\text { reflood }}$ & \pm 20.3 & 21.81 & -0.30 & $60.88 \pm 0.53$ & $-8.43 \pm 0.21$ & $-0.387 \pm 0.008$ \\
\hline
\end{tabular}




\begin{tabular}{|c|c|c|c|c|c|c|c|c|c|c|}
\hline \multirow{3}{*}{$\begin{array}{l}\text { Step/ } \\
\text { Zone }\end{array}$} & \multirow{3}{*}{$\begin{array}{c}\text { Vo id ed } \\
\text { Region, mm }\end{array}$} & \multirow{3}{*}{$\begin{array}{l}\text { Na Mass, } \\
\text { kg/St ep }\end{array}$} & & \multicolumn{6}{|c|}{ Worth Components, $\mathrm{c} \notin / \mathrm{kg}$} & \multirow[b]{3}{*}{$C / E$} \\
\hline & & & & \multicolumn{4}{|c|}{ Leakage } & \multirow{2}{*}{$\begin{array}{c}\text { Non- } \\
\text { Leakage }\end{array}$} & \multirow[b]{2}{*}{ Net } & \\
\hline & & & $k_{e} f f$ & $\mathbf{x}$ & $y$ & $\mathrm{z}$ & Sum & & & \\
\hline Reference & --- & -- & 0.975876 & -- & -- & -- & --- & --- & -- & $-\infty$ \\
\hline $1 / 1$ & 203 & 21.90 & 0.976104 & -0.095 & -0.011 & -0.050 & -0.156 & 0.491 & 0.335 & 1.03 \\
\hline $2 / 1$ & $203-305$ & 10.28 & 0.976125 & -0.069 & -0.008 & -0.234 & -0.311 & 0.374 & 0.063 & 1.09 \\
\hline $3 / 2$ & 305 & 96.15 & 0.977017 & -0.018 & -0.057 & -0.107 & -0.182 & 0.477 & 0.295 & 0.98 \\
\hline $4 / 3$ & 305 & 55.51 & 0.977643 & -0.106 & $\cdot-0.007$ & -0.158 & -0.271 & 0.630 & 0.359 & 1.07 \\
\hline $5 / 4$ & 305 & 35.26 & 0.978010 & -0.013 & -0.003 & -0.133 & -0.149 & 0.477 & 0.331 & 1.20 \\
\hline $6 / 5$ & 305 & 50.68 & 0.977632 & -0.419 & -0.021 & -0.078 & -0.518 & 0.281 & -0.237 & 1.04 \\
\hline $7 / 6$ & 203 & 11.01 & 0.977970 & -0.060 & -0.004 & -0.048 & -0.112 & 1.084 & 0.972 & 1.14 \\
\hline $8 / 7$ & 203 & 9.94 & 0.978249 & -0.071 & -0.005 & -0.045 & -0.121 & 1.059 & 0.938 & 1.09 \\
\hline $9 / 1 d$ & $(203)$ & $(21.90)$ & 0.977982 & 0.092 & 0.011 & 0.059 & 0.162 & -0.507 & -0.345 & 0.89 \\
\hline
\end{tabular}

aThe calculations followed the experimental sequence of steps. Refer to Figs. 7.1 and 7.2 .

${ }^{b}$ Relative to midplane, depth into each half of the reactor.

$c_{B_{\text {eff }}}=0.003295$.

dIn step 9, Na was re-inserted with all other zones voided. 
TABLE 7.3. Comparison of Calculated and Heasured Results for the ZPPR-13A Sodium-void Reactivity Experiments

\begin{tabular}{|c|c|c|c|c|}
\hline Step ${ }^{a}$ & $\begin{array}{l}\text { Measured } \\
\text { Worth, } \& / \mathrm{kg}\end{array}$ & $C / E$ & $P / E^{b}$ & $\sigma(P / E)$ \\
\hline 1 & $0.324 \pm 0.010$ & 1.034 & 0.949 & 0.067 \\
\hline 2 & $0.058 \pm 0.019$ & 1.086 & 0.985 & 0.465 \\
\hline 3 & $0.300 \pm 0.004$ & 0.983 & 0.902 & 0.065 \\
\hline 4 & $0.335 \pm 0.005$ & 1.072 & 0.982 & 0.078 \\
\hline 5 & $0.276 \pm 0.007$ & 1.198 & 1.099 & 0.074 \\
\hline 6 & $-0.228 \pm 0.005$ & 1.039 & 0.960 & 0.125 \\
\hline 7 & $0.852 \pm 0.002$ & 1.141. & 1.048 & 0.057 \\
\hline 8 & $0.860 \pm 0.024$ & 1.091 & 1.001 & 0.057 \\
\hline
\end{tabular}

a Refer to Figs. 8.1 and 8.2.

${ }^{b}$ Calculation adjusted by bias factors for leakage and non-leakage terms.

MR-A 20 


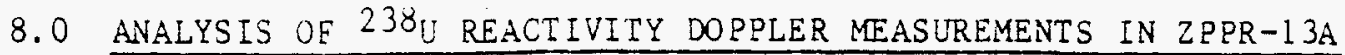

The calculation of Doppler worth for the sample is based on first order perturbation theory. The sample is explicitly modelled in the reactor calculation and, the perturbation is defined as the change from reference temperature to elevated temperature cross sections for the sample. In order to normalize the perturbation denominator and integrate over sample length, the axial flux shape is represented as $\phi(x y z)=\phi(x y) \cos B_{z}$, where $B_{z}$ is a constant buckling value chosen so that an $x y$ calculation with constant buckling gives the same $k_{e f f}$ as the reference case with group- and region-dependent values.

Preparation of the Doppler sample cross section data is based on a pin cell model. A two region pin cell consisting of the Doppler sample at the center surrounded by structural steel, is processed in $M^{2}-I I / S D X$ for each temperature to produce resonance self-shielded cross sections in an intermediate (156) group structure. For group collapse to the 28 group level, a diffusion calculation is done for a one-dimensional cylindrical model consisting of sample, structure and reactor core. Cross sections are collapsed for each sample temperature.

The core configuration was that of the $2 P P R-13 A$ critical reference with the Doppler mechanism and an additional fuel "spike" inserted. Both of these were included in the calculational model. The axial bucklings were derived from the xyz diffusion calculation for the reference core, and anisotropic diffusion coefficients were used. The $Z P P R$ shim rods were not modelled.

The measurements were performed near the center of fuel rings one and two, and toward the outer edge of fuel ring three, the latter dictated by available locations. The experimental values reported here differ slightly from those 
reported earlier $(16)$ because of adjustment to nominal temperatures for comparison with calculation. The adjustment is accomplished by means of a powerlaw Eit.

The comparison between experiment and calculation for the Doppler reactivity is shown in Table 8.1. The mean $C / E$ results of $0.84,0.88$ and 1.11 in the three fuel rings show the general variation with radius expected from analys is of other parameters. Sample worth data at the reference temperature are presented in Table 8.2. Again, the $C / E$ values have the expected radial variation. The radial variation of the reactivity Doppler C/E was found to follow the square of the $238_{U}(n, \gamma) \mathrm{C} / \mathrm{E}$ in $Z P P R-11$. The ratio of Doppler $\mathrm{C} / \mathrm{E}$ to the square of the reaction rate $C / E$ was found to be $0.732 \pm 0.033$ for $2 P P R-11 B$, and $0.738 \pm 0.017$ for $2 P P R-11 C$. The same analys is for the $2 P P R-13 A$ data yields the results shown in Table 8.3 . The ratios in fuel ring one (0.77) and fuel $r$ ing two $(0.78)$ are consistent and comparable to the results in $2 P P R-11$. Fuel ring three shows a significantly higher $r a t i o$ which is inconsistent with the rest of the data. There are three reasons, in addition to the reaction rate comparison, why the fuel-ring three measurement is suspect. First, in instal1ing the Doppler mechanism at that location, two shim rods had to be removed. Thus, during data acquisition, the reactor was held at power by balancing on six instead of eight shim rods. Experience with the 1 arge heterogeneous cores indicates that the resulting flux tilt could significantly influence the result. In addition, the magnitude of the measurement was very small, tending to increase the uncertainties and the flux gradient was very steep at the measurement location, introducing difficulties in modelling. In addition, there is a much larger variation in $C / E$ values for the different temperatures in the fuel $r$ ing three measurement. For these reasons, the fuel ring three measurement is felt to be unreliable. 
The C/E values in $2 P P R-13 A$ are generally comparable to those from $2 P P R-11$. (17)

The results in $2 P P R-11 B$ were 0.77 and 0.93 in the inner and outer fuel zones.

The results in ZPPR-11C (the EOC core) varied between 0.82 and 0.89 . The value in fuel $r$ ing two is close to the value obtained at the center of the homogeneous ZPPR -9 core $(0.935 \pm 0.007)$.(1) 
TABLE 8.1. Comparison of Measured and Calculated Doppler Reactivities for $2 P P R-13 A$

\begin{tabular}{|c|c|c|c|}
\hline \multirow[b]{2}{*}{ Temperature, $\mathrm{K}$} & \multicolumn{2}{|c|}{ Spec ific Worth, ${ }^{a} \mathrm{k} / \mathrm{kg} \quad 238_{\mathrm{U}}$} & \multirow[b]{2}{*}{$\mathrm{C} / \mathrm{E}$} \\
\hline & Exper iment ${ }^{b}$ & Calculation & \\
\hline $\begin{array}{c}\text { Fuel Ring } 1 \quad(153-56) \\
500 \\
650 \\
800 \\
950 \\
1100\end{array}$ & $\begin{array}{l}-0.0119 \pm 0.0006 \\
-0.0214 \pm 0.0007 \\
-0.0263 \pm 0.0006 \\
-0.0312 \pm 0.0006 \\
-0.0358 \pm 0.0006\end{array}$ & $\begin{array}{r}-0.0112 \\
-0.0172 \\
-0.0222 \\
-0.0264 \\
-0.0299 \\
\text { Me an C/E }\end{array}$ & $\begin{array}{l}0.938 \pm 0.051 \\
0.803 \pm 0.026 \\
0.844 \pm 0.019 \\
0.846 \pm 0.016 \\
0.835 \pm 0.013 \\
0.839 \pm 0.014\end{array}$ \\
\hline $\begin{array}{l}\text { Fuel Ring } 2(163-52) \\
500 \\
650 \\
800 \\
950 \\
1100\end{array}$ & $\begin{array}{l}-0.0134 \pm 0.0006 \\
-0.0228 \pm 0.0006 \\
-0.0301 \pm 0.0006 \\
-0.0352 \pm 0.0006 \\
-0.0410 \pm 0.0006\end{array}$ & $\begin{array}{r}-0.0134 \\
-0.0205 \\
-0.0264 \\
-0.0314 \\
-0.0355 \\
\text { Mean C/E }\end{array}$ & $\begin{array}{l}1.000 \pm 0.045 \\
0.899 \pm 0.023 \\
0.877 \pm 0.017 \\
0.892 \pm 0.015 \\
0.866 \pm 0.013 \\
0.884 \pm 0.012\end{array}$ \\
\hline $\begin{array}{c}\text { Fuel Ring } 3 \text { ( } 164-68) \\
500 \\
800 \\
950 \\
1100\end{array}$ & $\begin{array}{l}-0.0044 \pm 0.0006 \\
-0.0128 \pm 0.0006 \\
-0.0130 \pm 0.0006 \\
-0.0167 \pm 0.0006\end{array}$ & $\begin{array}{r}-0.0070 \\
-0.0138 \\
-0.0164 \\
-0.0186 \\
\text { Mean C/E }\end{array}$ & $\begin{array}{l}1.593 \pm 0.221 \\
1.077 \pm 0.051 \\
1.266 \pm 0.060 \\
1.114 \pm 0.037 \\
1.141 \pm 0.035\end{array}$ \\
\hline
\end{tabular}

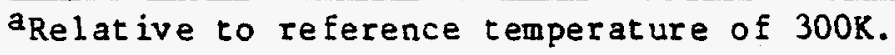

buncertainties include equal contributions from both end points and 0.0003 temperature uncertainty (equivalent to $\pm 5 \mathrm{~K}$ in average temperature). 
TABLE 8.2. Comparison of Measured and Calculated Values for ${ }^{238} \mathrm{U}$ Doppler Sample Worth in Fuel Rings of ZPPR-13A

\begin{tabular}{|c|c|c|c|}
\hline $\begin{array}{l}\text { Me as ur ement } \\
\text { Locat ions }\end{array}$ & Exper iment, $d / \mathrm{kg}$ & Calculation, $6 / \mathrm{kg}$ & $C / E$ \\
\hline $\begin{array}{l}\text { Fue 1 Ring } 1 \\
(153-56)\end{array}$ & $-0.457 \pm 0.001$ & -0.410 & $0.897 \pm 0.002$ \\
\hline $\begin{array}{c}\text { Fuel Ring } 2 \\
(163-52)\end{array}$ & $-0.526 \pm 0.001$ & -0.491 & $0.933 \pm 0.002$ \\
\hline $\begin{array}{c}\text { Fuel Ring } 3 \\
(164-68)\end{array}$ & $-0.0726 \pm 0.001$ & -0.0724 & $0.997 \pm 0.018$ \\
\hline
\end{tabular}

TABLE 8.3. Values of Average C/E for $238_{\mathrm{U}}$ Doppler Measurements Compared with Average $(C / E)^{2}$ for $23 \delta_{U}(n, \gamma)$ Foil Measurements in $\mathrm{ZPPR}-13 \mathrm{~A}$

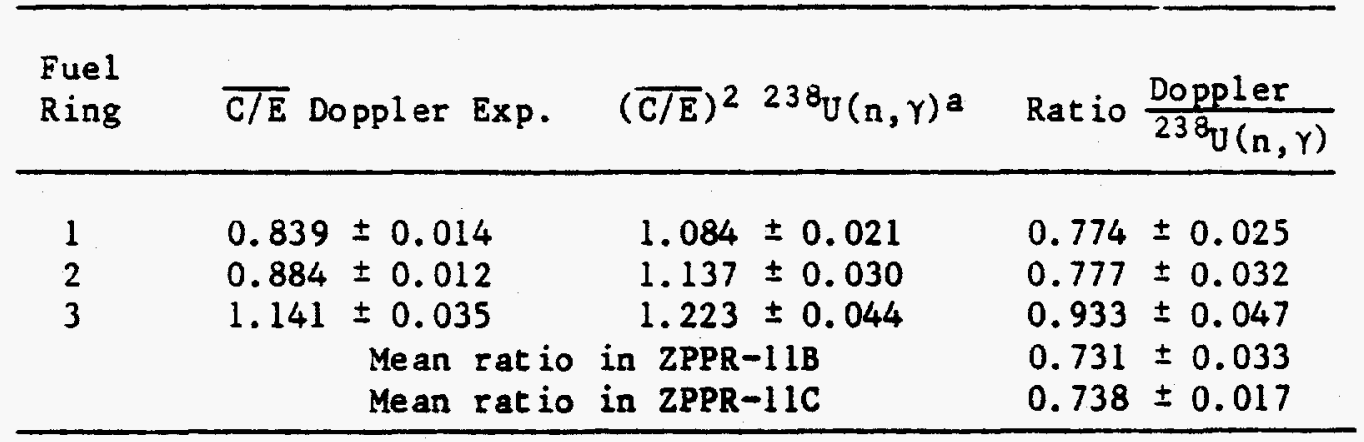

avalue quoted represents the average of all foils in that zone, and is squared for comparisons with the reactivity. 


\subsection{SMALL SAMPLE REACTIVITIES}

The reactivity worths of small samples of materials were measured in 2PPR-13A using the radial and axial tube method, the long-drawer oscillator and the shim-blade oscillator. Only the results from the radial tube have been analyzed at the present time.

The calculated reactivities were obtained from xyz calculations with 28 group data and included anisotropic diffusion. Homogeneous cell compositions were used in the model (HMM) and the ZPPR shim rods were not represented. Sample-size corrections were calculated with the SARCASM code(18) as a function of position, using the xyz fluxes and adjoints.

A description of the measurements and detailed results are given in Ref. 19. A description of the samples is given in Table 9.1. The calculated and experimental results are shown in Figs. 9.1 to 9.7. The curves shown in the figures are obtained by by a least squares fitting to the fourteen calculated and measured results in the fuel zones along the $x$-axis traverse. The results of two fittings are shown; the first adjusts the calculated non-leakage and leakage components and the second (dashed-curve) fits to the total worth. For the fissile samples and boron, where the leakage is a small component of the total worth, the two fits are ind istinguishable and the bias factor for the non-leakage component is the same as the C/E for the sample worth. For scattering samples (carbon and iron) and $\mathrm{DU}-6\left(238_{\mathrm{U}}\right.$ ) the two-component fit produces much improved agreement. One may speculate that some of the large adjustments to the calculated leakage in these cases ( $40 \%$ to $80 \%$ ) may be associated with streaming effects in the sample tube.

The bias factors for non-leakage components are summarized in Table 9.2. Results for fissile samples and boron are within a few percent of those obtained in $2 P P R-9$ and $2 P P R-10$ (al so shown in the table). The $\mathrm{C} / \mathrm{E}$ for ${ }^{239} \mathrm{Pu}$ is 1.20. 
The results for ${ }^{235} \mathrm{U}$, samples $U-6$ and $\mathrm{kSS}-1$ (named after one of the more illustrious members of the $2 P P R$ analysis group), are about $3 \%$ higher. The $C / E$ for boron is much lower at 1.06 . It is difficult to draw any conclusions from the results for $238 \mathrm{y}$, iron and carbon because of the 1 arge adjustments required to the leakage components. Transport effects are expected to be significant in these cases, based on analysis of $238 \mathrm{~J}$ fission rates and sodium void reactivity in the heterogeneous cores.

Corrections to the radial traverses for variations in master compositions will increase calculated sample worths (at least for those with small leakage components) in fuel ring 1 relative to fuel ring 3 about $2 \%$. It is clear from Figs. 9.1, 9.2 and 9.3 that this will give some improvement in the fit to the experimental results for the fissile samples. However, the remaining discrepancies of $5 \%$ to $10 \%$ between the fuel zones are consistent with analys is of control rod worths and reaction rates. 


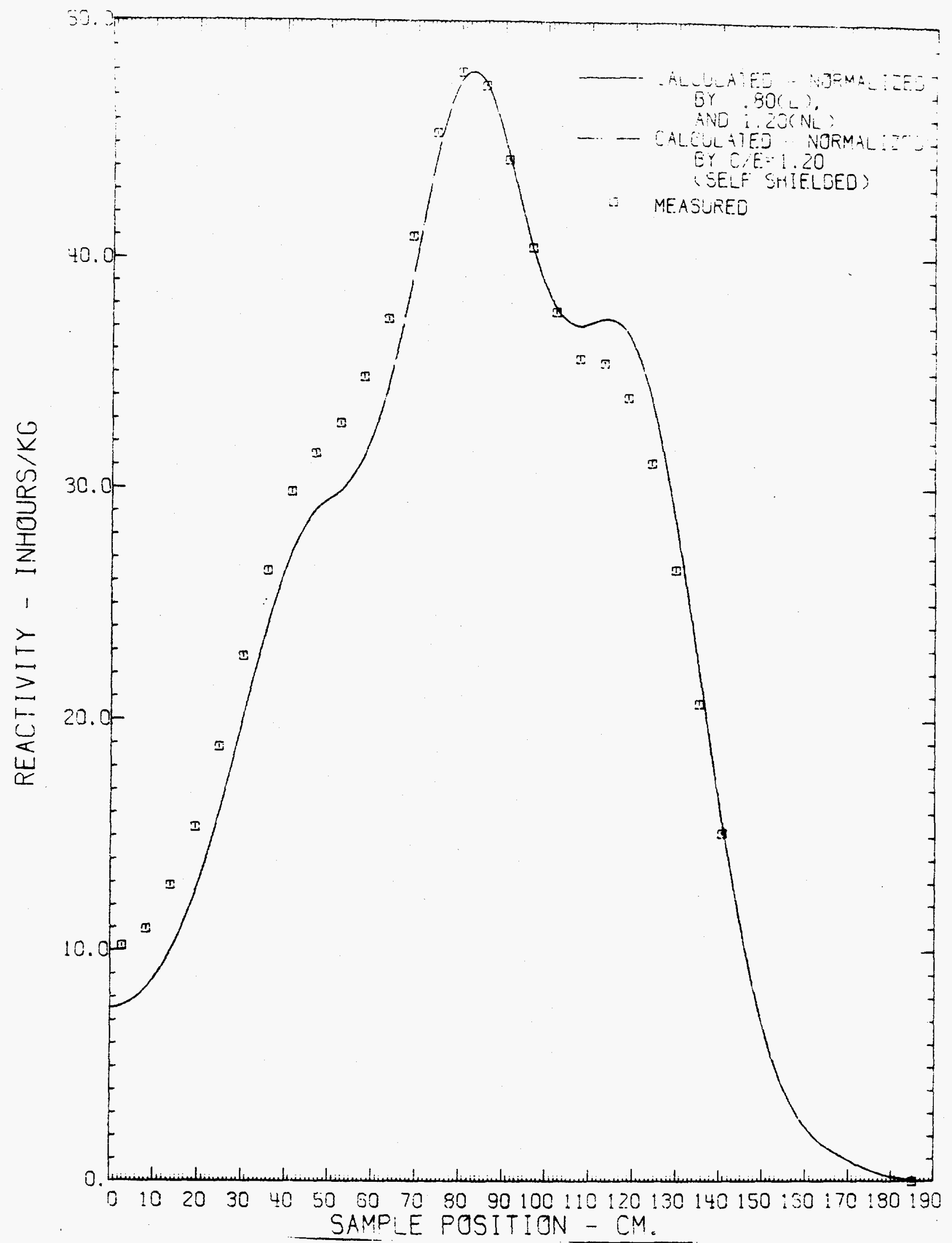

Fig. 3.1. Measured and calculated radial reactivity worth profiles for the PU-30 sample in ZPPR-13A. 


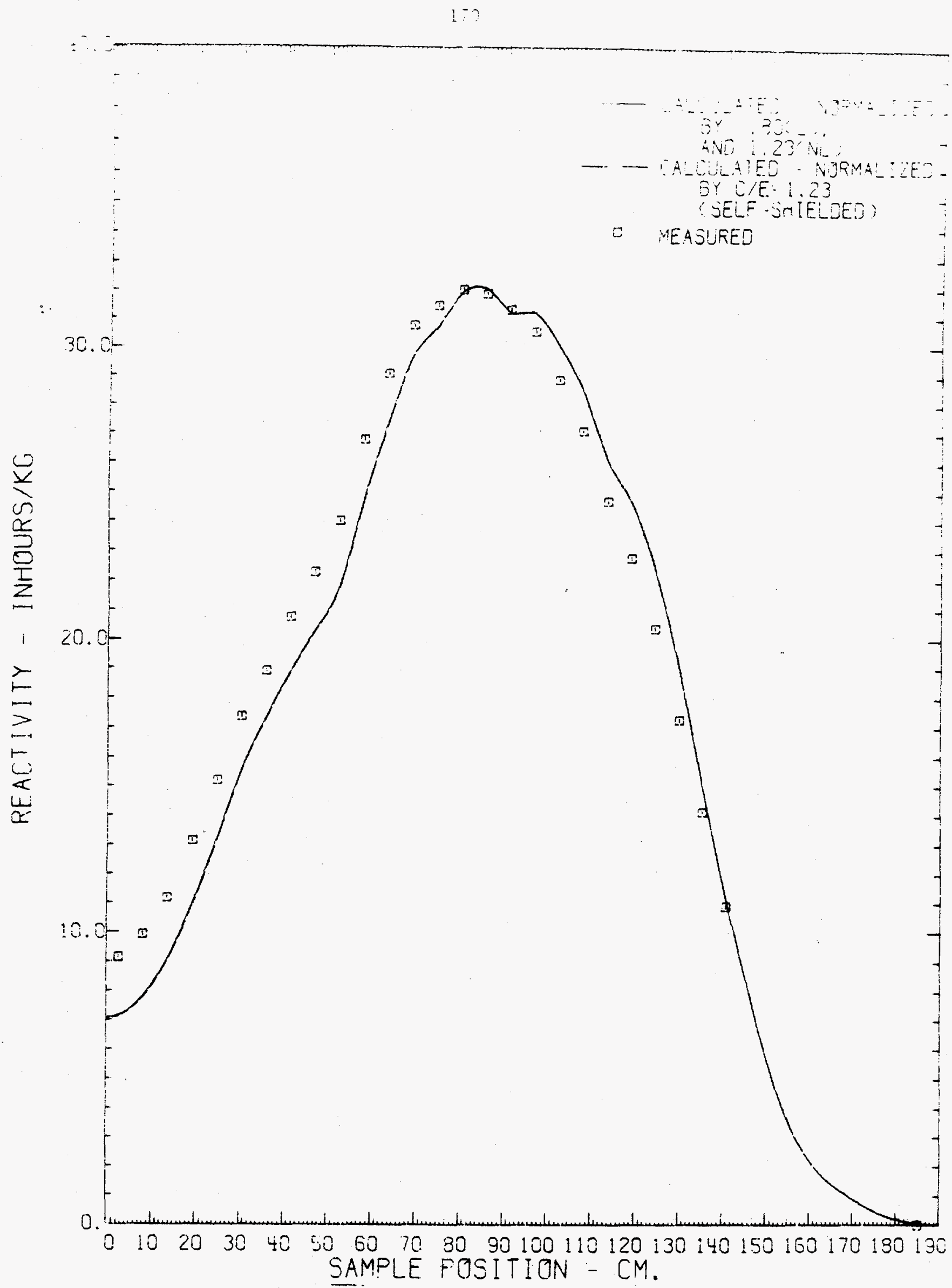

Fig. 9.2. Measured and calculated radial reactivity worth profiles for the U-6 sample in ZPPR-13A. 


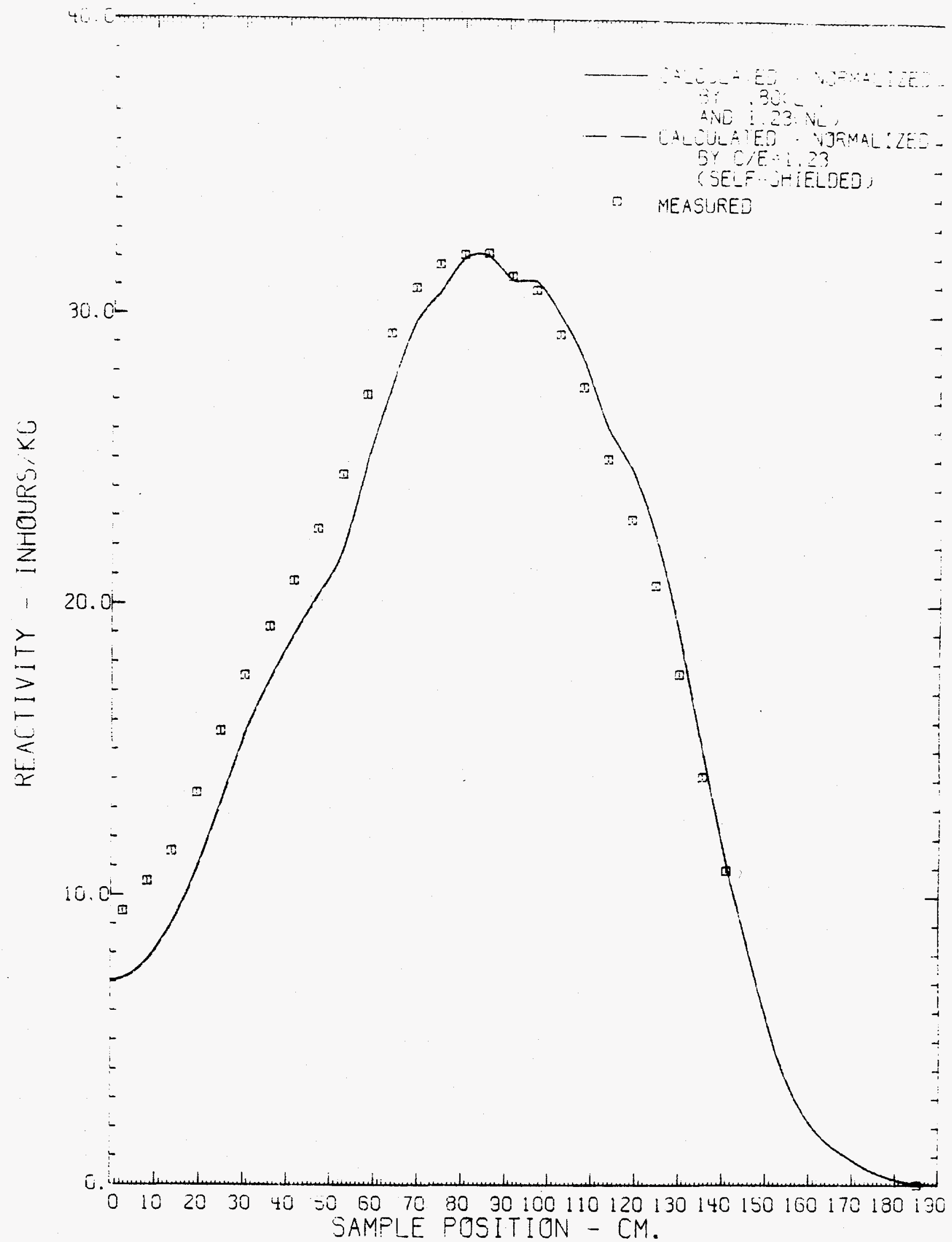

Fig. 9.3. Measured and calculated radial reactivity worth profiles for the KSS-1 sample in ZPPR-13A. 


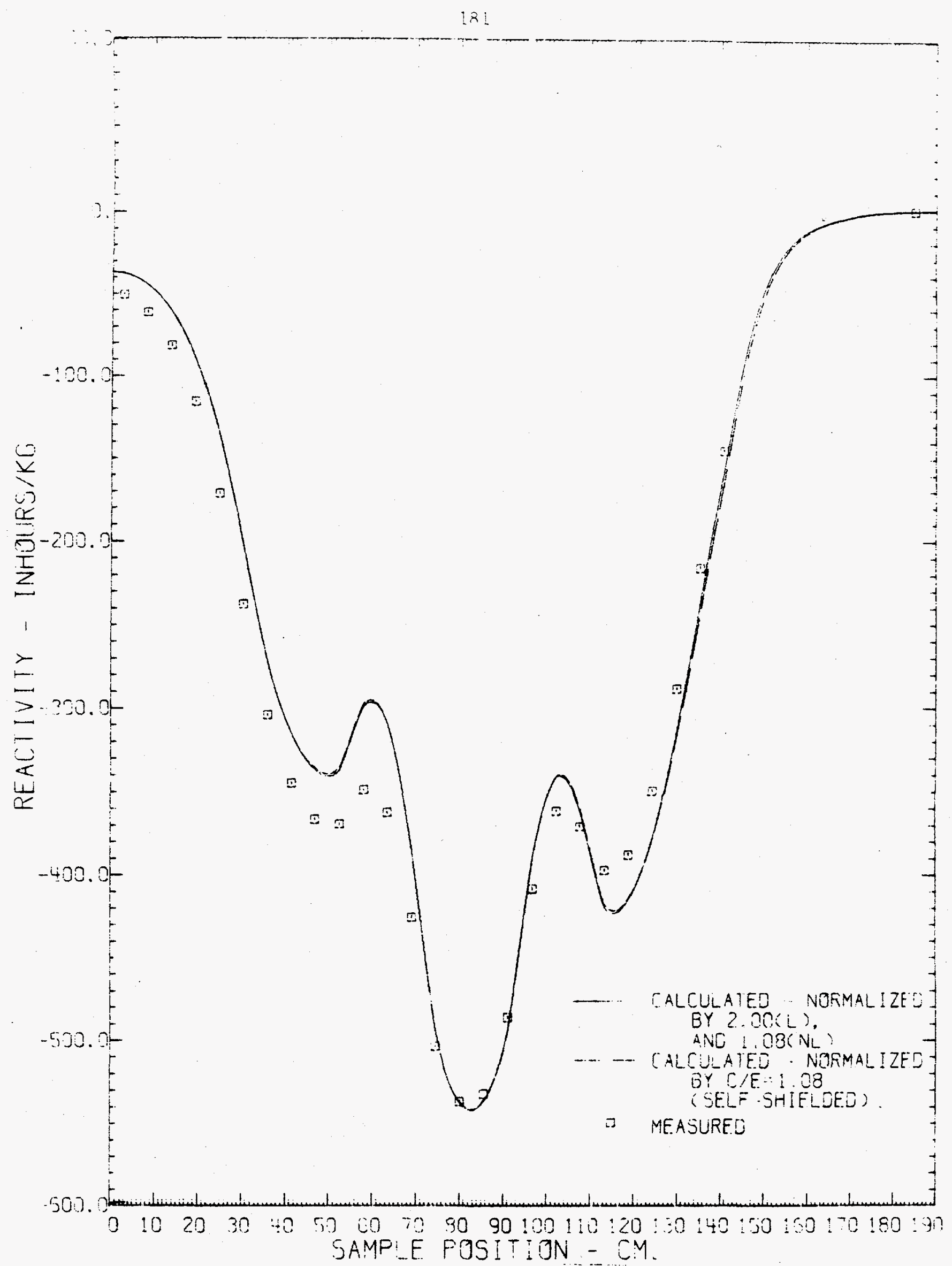

Fig. 9.4. Measured and calculated radial reactivity worth profiles for the B-1 sample in ZPPR-13A. 


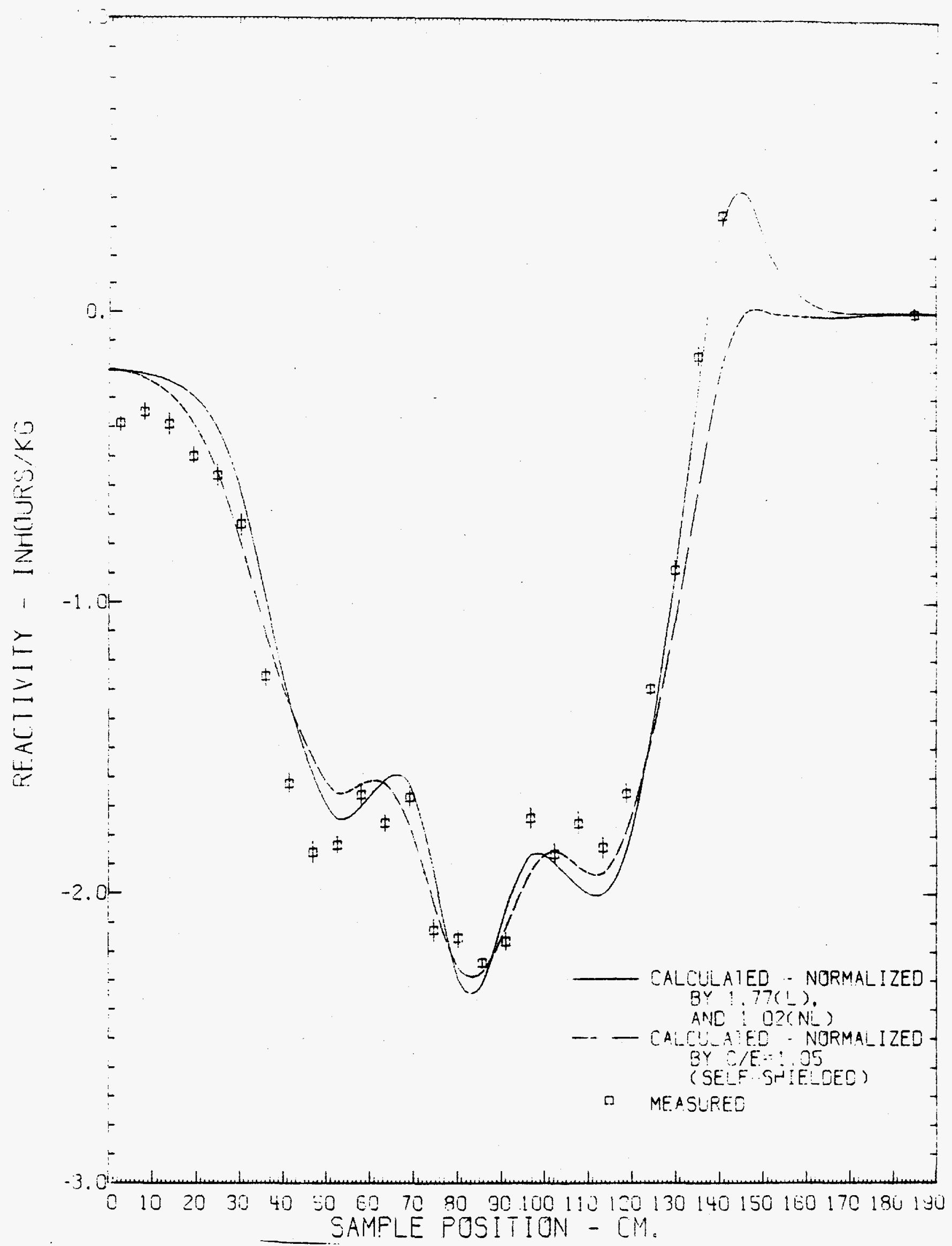

Fig. 9.5. Measured and calculated radial reactivity worth profiles for the DU-6 sample in ZPPR-13A. 


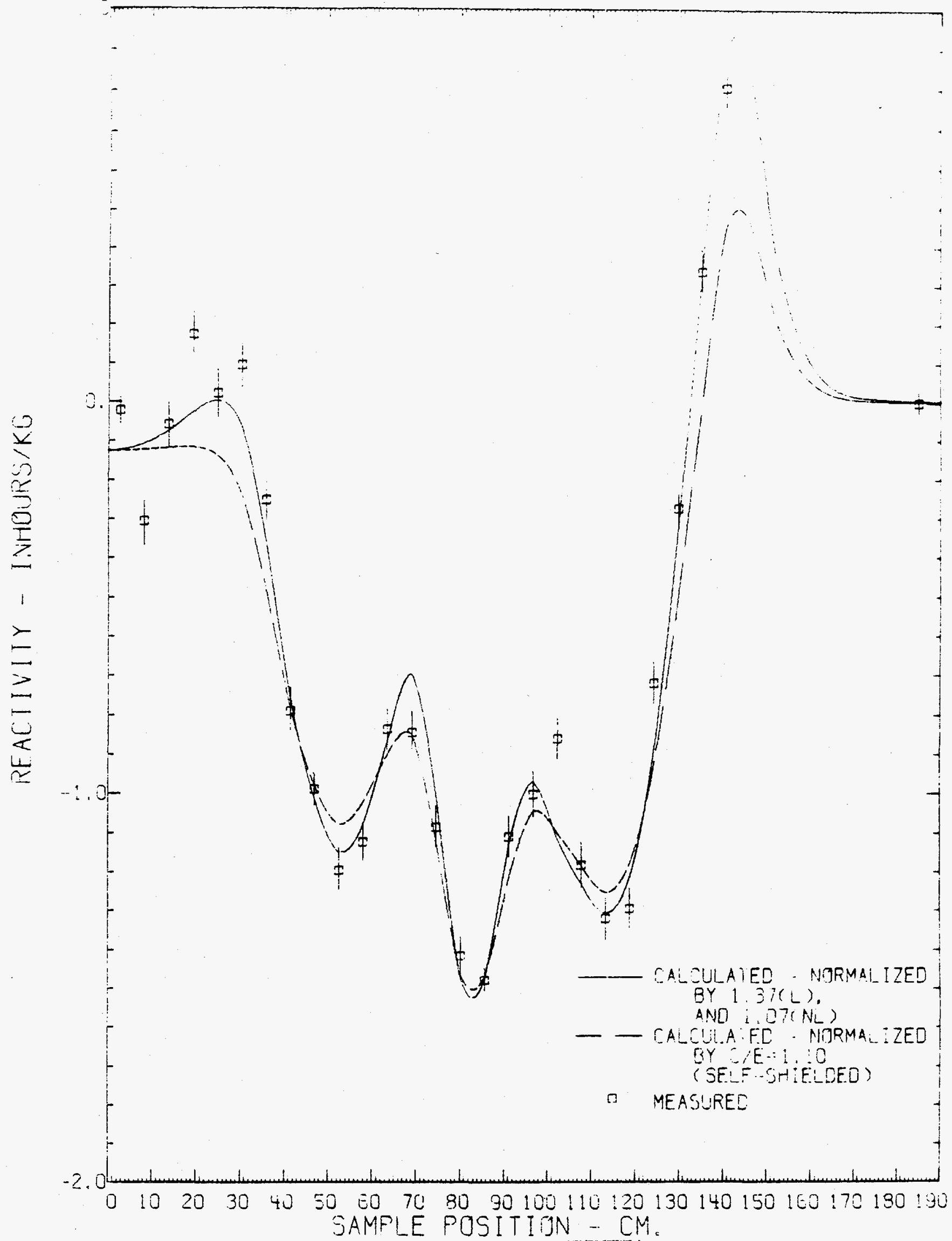

Fig. 9.6. Measured and calculated radial reactivity worth profiles for the $\mathrm{Fe}-1$ sample in 2PPR-13A. 


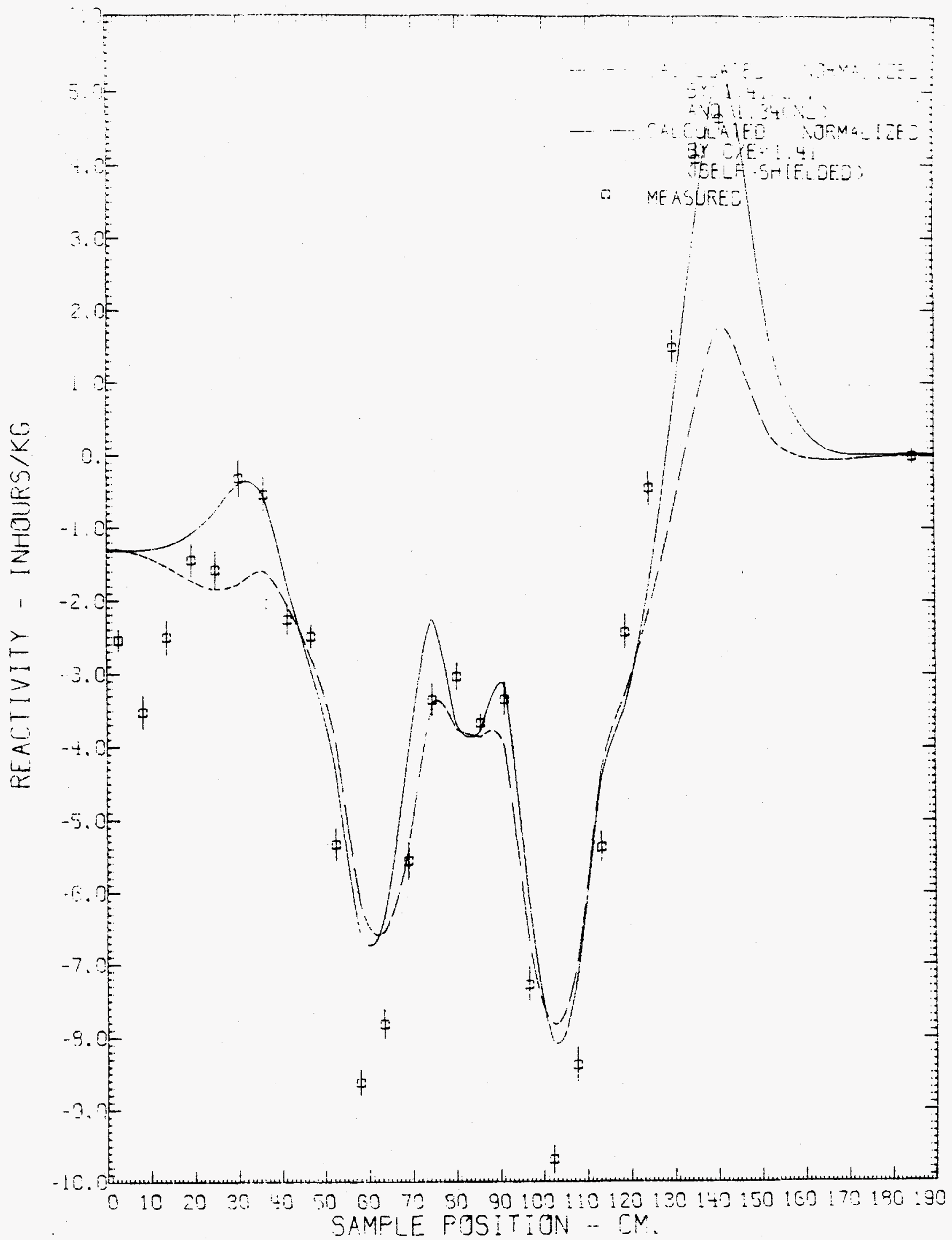

Fig. 9.7. Measured and calculated radial reactivity worth profiles for the C-1 sample in ZPPR-13A. 
TABLE 9.1. Description of the Reactivity-Worth Samples Used in ZPPR-13A

\begin{tabular}{|c|c|c|c|c|c|c|}
\hline \multirow[b]{2}{*}{ Sample } & \multicolumn{2}{|c|}{$\begin{array}{c}\text { Sample } \\
\text { Dimensions, } \mathrm{mm}\end{array}$} & \multirow{2}{*}{$\begin{array}{l}\text { Sample } \\
\text { Mass, } g \\
\end{array}$} & \multirow{2}{*}{$\begin{array}{l}\text { Capsule } \\
\text { Mass, } \mathrm{g}^{\mathrm{a}}\end{array}$} & \multicolumn{2}{|c|}{$\begin{array}{l}\text { Principal } \\
\text { Composition }\end{array}$} \\
\hline & Length & $0 . D_{0}$ & & & Component & wt. $\% b$ \\
\hline $\mathrm{KSS}-1 \mathrm{C}$ & 40.64 & 6.35 & 37.42 & 7.030 & $\begin{array}{l}234 U \\
235 U \\
236 U \\
238 U\end{array}$ & $\begin{array}{r}0.95 \\
93.19 \\
0.30 \\
5.57\end{array}$ \\
\hline $\mathrm{KSS}-2$ & 48.67 & 10.67 & -- & 7.005 & St ainless & Steel \\
\hline$B-1$ & 55.22 & 10.19 & 4.193 & 10.521 & $\begin{array}{c}10_{\mathrm{B}} \\
11_{\mathrm{B}} \\
0 \\
\mathrm{C} \\
\mathrm{Si} \\
\mathrm{Al} \\
\mathrm{H}\end{array}$ & $\begin{array}{r}87.12 \\
7.38 \\
1.43 \\
0.96 \\
0.26 \\
0.05 \\
0.09\end{array}$ \\
\hline $\mathrm{Fe}-1$ & 55.17 & 9.88 & 33.277 & 10.611 & $\mathrm{Fe}$ & 99.99 \\
\hline$C-1$ & 55.22 & 9.93 & 8.027 & 10.672 & C & 99.99 \\
\hline$D-1$ & 66.50 & 10.75 & -- & 10.668 & St ainless & Steel \\
\hline $\mathrm{Pu}-30$ & 55.19 & 7.62 & 38.091 & 11.600 & $\begin{array}{r}239 \mathrm{Pu} \\
240 \mathrm{Pu} \\
241 \mathrm{Pu} \\
\mathrm{Al}\end{array}$ & $\begin{array}{r}97.20 \\
1.01 \\
0.04 \\
0.95\end{array}$ \\
\hline$U-6$ & 55.19 & 7.62 & 46.889 & 11.463 & $\begin{array}{l}234 U \\
235 U \\
236 U \\
238 U\end{array}$ & $\begin{array}{r}0.95 \\
93.19 \\
0.26 \\
5.60\end{array}$ \\
\hline $\mathrm{DU}-6$ & 55.19 & 7.62 & 47.427 & 11.417 & $\begin{array}{l}235 U \\
238 U\end{array}$ & $\begin{array}{r}0.21 \\
99.78\end{array}$ \\
\hline$D-13$ & 66.59 & 10.77 & -- & 11.653 & Stainless & Steel \\
\hline
\end{tabular}


TABLE 9.2. Analys is of Reactivity Samples from Radial Traverses in ZPPR-13A and Comparison with Results from ZPPR-9 and ZPPR-10

\begin{tabular}{|c|c|c|c|c|c|}
\hline \multirow[b]{2}{*}{ S ample } & \multirow{2}{*}{$\begin{array}{c}\text { Pr inc ipal } \\
\text { I sotope }\end{array}$} & \multicolumn{4}{|c|}{ Non-leakage Ad justment Factor ${ }^{a}$} \\
\hline & & ZPPR $-13 \mathrm{~A}$ & ZPPR-9 & $2 P P R-10 A$ & ZPPR-10B \\
\hline $\mathrm{Pu}-30$ & $239 \mathrm{Pu}$ & 1.20 & 1.16 & 1.17 & 1.17 \\
\hline$U-6$ & 2350 & 1.23 & 1.20 & 1.20 & - \\
\hline KS S-1 & $235_{\mathrm{U}}$ & 1.23 & - & -- & -- \\
\hline $\mathrm{B}-1$ & $10_{B}$ & 1.06 & 1.06 & 1.06 & 1.05 \\
\hline$D U-6$ & $238_{U}$ & 1.05 & 1.14 & 1.14 & 1.13 \\
\hline $\mathrm{FE}-1$ & $56_{\mathrm{Fe}}$ & 1.07 & 1.37 & -- & $\rightarrow$ \\
\hline SS -1 & (steel) & - & 1.30 & 1.19 & -- \\
\hline$c-1$ & $12 \mathrm{C}$ & 1.34 & - & 1.55 & -- \\
\hline
\end{tabular}




\subsection{SUMMARY}

\section{Critical Mass}

Diffusion theory calculations for $2 P P R-13$ give $k$-effective results in the range 0.976 to 0.979 .

The results are within $0.2 \% \Delta k$ of those for the smaller heterogeneous cores, $2 P P R-7$ and $2 P P R-11$. The small differences may be due as much to changes in cross section processing methods for the unit cells as to differences in core size and configuration.

The diffusion theory $k$-effective values are between $0.3 \% \Delta k$ and $0.5 \% \Delta k$ lower than for conventional cores. Transport effects are larger in the heterogeneous cores and the corrected value of 0.986 for $2 P P R-13 A$ is in good agreement with $2 P P R-9$ and $2 P P R-10$.

\section{Reaction Rate Distributions}

A distinctive pattern of misprediction of reaction rates as a function of radius is found for all reactions in all cores. The $\mathrm{C} / \mathrm{E}$ results in the inner zones are $3 \%$ to $5 \%$ lower than in the outer fuel zone.

$$
\text { The discrepancy is increased by }
$$

about $0.5 \%$ with transport calculations.

Axial distributions show lower values at the top of the core, near the axial blanket interface, by about $1 \%$ relative to the core average.

\section{Reaction Rate Ratios}

The results are similar to those in all other ZPPR analys is with ENDF/B-IV data. Relative to $239_{\mathrm{Pu}}$ fission, $235_{\mathrm{U}}$ fission is overpredicted by $3 \%$ and $238 \mathrm{U}$ capture is overpredicted by $6 \%$ to $9 \%$.

Diffusion calculations for $238_{\mathrm{U}} \mathrm{f}$ ission show differences of about $15 \%$ between fuel and internal blanket zones. The results are much improved by transport calculations, but a discrepancy of $5 \%$ persists in the present analyses. 


\section{Control Rod Worths}

Predictions of rod worths relative to fuel vary in the range $0.98(F L)$, $1.00(\mathrm{~F} 2) 1.06(\mathrm{~F} 3)$.

The radial variations in $C / E$ are about twice those observed for reaction rates. Transport corrections increase the radial discrepancies.

Control rod interaction effects are we 11 predicted with simple diffusion theory calculations.

The worths of CRPs relative to fuel are grossly overpredicted by isotropic diffusion calculations, consistent with previous analyses in other cores.

Results for rod-size, pin geometry and boron enrichment variations are consistent to within $2 \%$ using heterogeneity corrections calculated with diffusion theory. Some improvement is anticipated from transport calculations.

\section{Sodium Void Reactivity}

The diffusion theory results for zones in $2 P P R-13 \mathrm{~A}$ ( C/Es in range 0.98 to 1.20) are reasonably consistent with results from other cores.

\section{Doppler Reactivity}

The $C / E$ results in the first and second fuel rings $(0.88)$ are fairly consistent with analyses in $2 P P R-9$ and $2 P P R-11$. The result in the the third fuel $r$ ing is singularly out of 1 ine with other data and is considered to be unreliable.

\section{Sample Traverses}

The $C / E$ results for fissile samples of 1.2 are in 1 ine with other values from radial tube experiments. The reason for the large discrepancies compared 
with those from studies in the ANL "diagnostic" cores is presently unexplained and is of considerable interest. The present results for $238 \mathrm{U}$ and scattering samples should not be treated seriously due to expectation of substantial transport corrections and possible problems due to leakage in the tube environment. Cross Section Processing

Al 1 results obtained in $2 P P R-13$ are dependent on the viability of methods used to process cross sections for the cells in the complex environment of the heterogeneous criticals. At this stage it is not clear how much of the error in prediction of spatially-varying parameters is due to ENDF/B-IV data and how much is due to the cell-processing methods need. A Monte Carlo calculation using the VIM code will provide an essential test of the present methods.

\section{Reactor Modelling}

The enhanced sensitivities of the large heterogeneous cores has highlighted the need for consideration of fine details in the reactor loadings. Initial results with the "Al1-master-model" have produced improvements in consistency in the analysis. The first steps have been taken in the automated production of the calculational models from the detailed reactor loading files. 


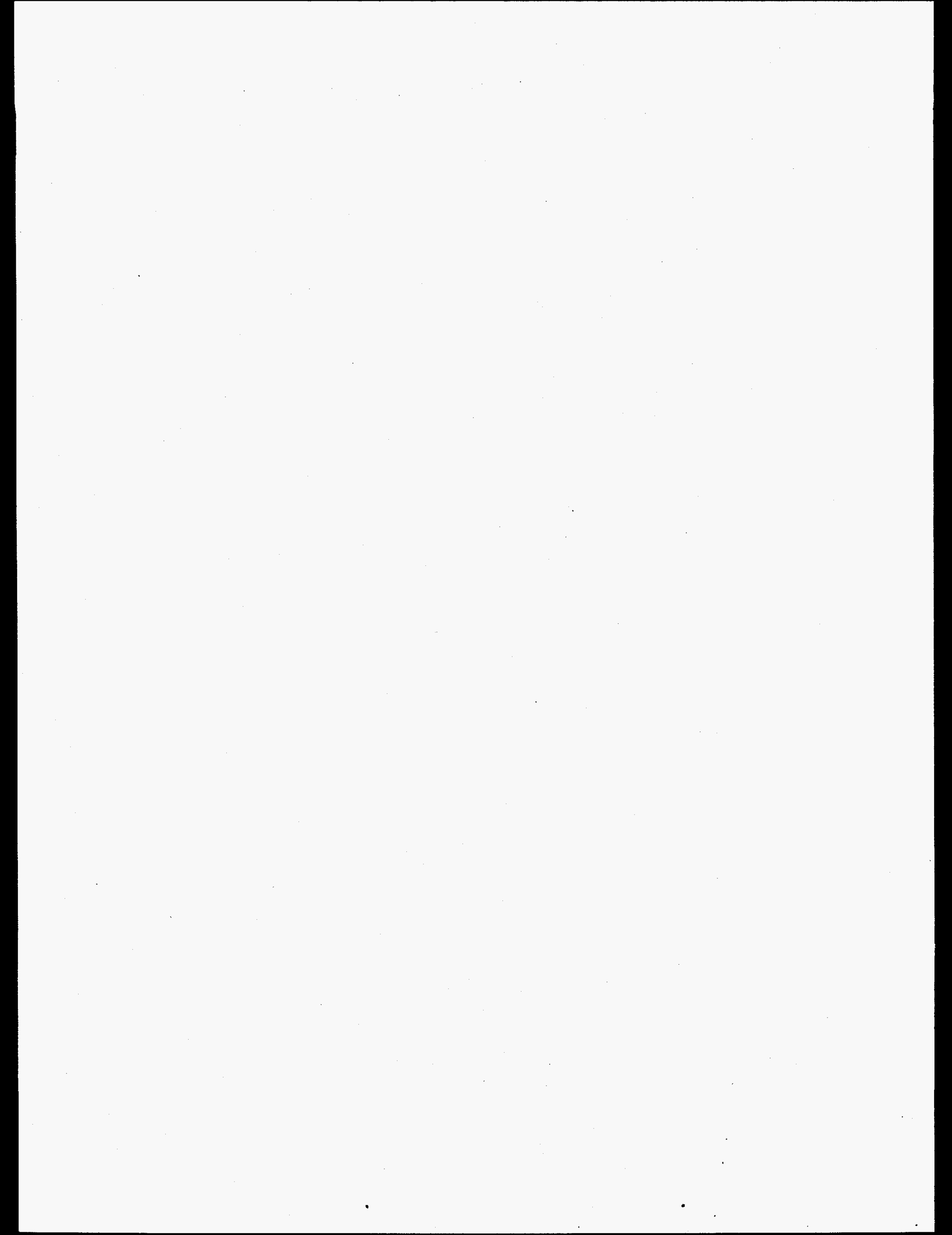




\section{REEERENCES}

1. The JUPITER Program: ANL Analysis of ZPPR-9, Report prepared for the First Meeting on JUPITER Program, September 11 and 12, 1980.

2. The JUPITER Program: Analysis of ZPPR-10, Report prepared for the Second Analysis Meeting on JUPITER Program, October 19-26, 1981.

3. M. J. Lineberry, H. F. McFarlane and P. J. Collins, "Physics Assessments of LMFBR Integral parameters," Proc. of the Topical Meeting on Advances in Reactor Physics and Core Thermal Hydraulics, Kiamesha Lake, New York, September 22-24, 1982 NUREG/CP-0034, Vol. 1, p. 1 (1982).

4. T. Ikegami, internal report, (1980), "Relevant sections included in UKAEA/USDOE exchange package."

5. S. G. Carpenter, "Measurements of Control Rod Worths using ZPPR," Proc. of the Specialists Meeting on Control Rod Measurements Technique: Reactivity Worth and Power Distribution, Cadarache, France, 19\%, NEACRP-U -75 .

6. P. J. Collins and S. B. Brumbach, eds., internal report, (1984), "Relevant sections included in UKAEA/USDOE exchange package."

7. M. J. Lineberry, et al., "Physios Studies of a Heterogeneous LiquidMetal Fast Breeder Reactor," Nuclear Technology, 44, p. 21 (1979).

8. S. B. Brumbach and P. J. Collins, eds., internal report, (1983), "Relevant sections included in UKAEA/USDOE exchange package."

9. S. B. Brumbach and S. G. Carpenter, internal report, (1983), "Relevant sections included in UKAEA/USDOE exchange package."

10. S. B. Brumbach and P. J. Collins, eds., internal report, (1983), "Relevant sections included in UKAEA/USDOE exchange package."

11. S. B. Brumbach and P. J. Collins, eds., internal report, (1984), "Relevant sections included in UKAEA/USDOE exchange package."

12. R. Avery, "Theory of Coupled Reactors," Proc. Second U.N. Intl. Conf. on Peaceful uses of Atomic Energy, 12, U.N. Publication, p. 186 (1958).

13. D. C. Wade and R. A. Rydin, "An Experimentally Measurable Relationship Between Asymptotic Flux Tilts and Eigenvalue Separation," Dynamics of Nuclear Systems, University of Arizona Press, Tuscon, Arizona (1972).

14. S. B. Brumbach and P. J. Collins, eds., internal report, (1984), "Relevant sections included in UKAEA/USDOE exchange package." 
15. H. F. McFarlane, et al., "Experimental Studies of Radially Heterogeneous Liquid-Metal Fast Breeder Reactor Critical Assemblies at the Zero Power Plutonium Reactor," Nucl. Sci. and Eng. 87, p. 204 $(1984)$.

16. P. J. Collins and S. B. Brumbach, eds., internal report, (1983), "Relevant sections included in UKAEA/USDOE exchange package."

17. R. E. Kaiser, et al., "Extrapolation of Small Sample Doppler Reactivity Measurements," Proc: of the Topical Meeting on Advances in Reactor Physics and Core Thermal Hydraulics, NUREG/CP-0034 p. 118 (1982).

18. P. J. Collins and R. G. Palmer, "Calculated Size Effects for Reactivity Perturbation Samples in ZPPR," Paper II-38 in Argonne National Laboratory Applied Physics Annual Report July, 1970 to June 30, 1971, ANL-7910, p. 247 (1972).

19. S. B. Brumbach and P. J. Collins, eds., internal report, (1983), "Relevant sections included in UKAEA/USDOE exchange package." 


\section{APPENDIX A}

Input Data for $\mathrm{MC}^{2}$ and SDX

The input data for generation of the 226 group library in $\mathrm{MC}^{2}-$ II is shown in Table A.1. The fine group spectrum is generated for the homogeneous composition of the double-fuel-column cells. A number of additional isotopes are added at negligibly low density for editing purposes. Isotopes labelled with an $S$ (e.g. NA23 S) use special resonance shielding treatment for narrow resonances.

A specimen input for $\operatorname{SDX}$ is shown in Table A.2. The case shown is the double-fuel-column drawer in fuel $r$ ing three. Zone bucklings in 28 groups are applied (on the $09 \mathrm{cards}$ ) to the 2082 fine groups of A MCC2, to the intermediate 226 groups of A. INTR and to the 226 groups of A.SEFID for calculation of a spectrum for group collapse. The special "MODL1B" incorporates a scaling of the input bucklings by a constant factor so as to obtain a $k_{e}$ ff of 0.986 for the heterogeneous cell. The SDX runs for the other cells are similar. 


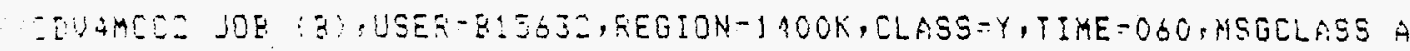

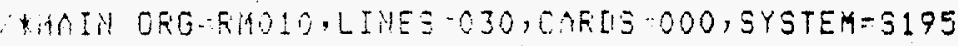

$\because k$

K** B15632, CIUSACC?

$\therefore *$

I/CU EXEC ARCSFOIS.

i/ VERSIOH: 1 , FORMAT -FITTS

//IUAMY I III SFACE $=$ (CYL, 100, CONTIG)

$1 /$ DUMAY 2 DD SFACE $-(C Y L, 180$, , CONTIG)

I/FTOSFOO1 [II SYSOUT $=*$

ISYSUDULF DIO DUMAY

I/FT18F001 III UNIT-(WRITS250),

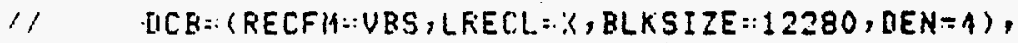

// VOL = (FRIVATE, RETAIN, SEF'=178816), LAEEL:-(O1,SL),

$1 /$ IISP:: (HEW,KEEF),

// DSN $=[117, B 15632$. GFOEL

//FT19FOO1 DD UMIT=(ALLFERM),

// DCE $=$ (RECFM U UBS, LFECL = X, BLKSIZE-6136),

$1 /$ SFACE $:(T R K,(250,10)$, RLSE $)$,

i) DISF $=$ (OLD,KEEF $)$,

/I [1SH-C11],B13632,CDVA226,ISOTXS

//FT37FOO1 DI UNIT-(SASCR), SUBALLOC $=(C Y L,(05,01)$, DUMHY1)

//FT3BFDO1 DD UYIT $=(S A S C F)$, SUBALLOC $=(C \% L,(30,01)$, DUMKY 1$)$

//FT39FO01 IIJ UNIT-(SASCE), SUBALLOC $=(C Y L,(5,5,01)$, DUMMY1)

//FTAOFOO1 DI UNIT = (SASCR $)$, SUBALLOC $=(C Y L,(05,01)$, DUMHY1)

//FTA1FO01 II UNIT=(SASCF), SUBALLOC:-(CYL, $(05,01)$, DUMMY1)

//FTA3FOOL DO SUBALLIIC $=(C \% L,(30,01)$, DUMMY 2$)$

//FTA9FOO1 DD UNIT=(ALLFERM),

// DCB $=($ RECFM $=$ URS, LRECL $-:$, BLKSIZE $=6136)$,

$/ / \quad$ SFACE $=(T R K,(01,01))$,

// IISF:: (NEN,CATLB),

// IISN $=C 117 . B 15632$. CDU12261

//FT5OFOOI DI UMIT: (WRIT6250),

// VOL = (FRIUATE, RETAIN, SER-178952),

$1 /$ LABEL $:(01, S L)$,

i) DCE $=($ RECFM $=$ UBS, LRECL $=$; ; BLKSIZE $=6136)$,

/I IISF - (HEW,KEEF),

II IISN $=$ C117.R15632.CIVA2262

I/FTS2FOOL DD SURALLOC- $(C Y L,(30,01)$, DUMMY 2$)$

//FTS3F001 IIO SUBALLOC $=(C Y L,(30.01)$, DUKKY 2$)$

I/FTJ1F001 DD SUBALLOC- $(C Y L,(30,01)$, DUAKY 2$)$

//FT55F001 DI SUBALLOC- (CYL, $(30.01)$, DUMMY 2$)$

//FT 36001 DO SUBALLOC- $(C Y L,(03,01)$, DUMAY2)

//FTS7FO01 DI SUBALLOC $=(C Y L,(03,01)$, DUMMY 2$)$

//FT58FOO1 DD SUBALLOC- $(C Y L,(03,01)$, DUMAY 2$)$

//FT59FO01 IID SUBALLOC $=(C Y L,(03,01)$, DUMAY2 $)$

I/FTSOFOO1 DI SUBALLOC $=(C Y L,(03,01)$, DUMMY 2$)$

//FT61F001 DII SUBALLOC=(CYL, $(03,01)$, DUMYY2)

I/FTS2FOOI QU SFACE:: $(C Y L,(50,5))$

I/SYSIN III *

BLOCK-STFO1S

IATASET $=$ A. STFO1S

$\begin{array}{llllllllllll}01 & 000 & 000 & 000 & 000 & 000 & 001 & 001 & 001 & 000 & 000 & 000\end{array}$ IIATASET $=A$. MCC2

01 VERSION 4, 226 GROUP LIBRARY GENERATIOK FOR SDY (ZFFR 12,13)

$02 \quad 120000 \quad 000 \quad 000$

$\begin{array}{lllllllllllllll}03 & 001 & 001 & 000 & 010455226 & 000 & 000 & 000 & 020 & 000 & 000\end{array}$

06

001000

$c-124$

$0.0000346 \quad 293.00$

$\begin{array}{lll}0-164 & 0.0098618 & 293.00 \\ \operatorname{Hn} 235 & 0.0086880 & 293.00\end{array}$

$06 \quad \operatorname{HA23} 5$

TABLE A. 1. Input Data for $\mathrm{MC}^{2}$ 


\begin{tabular}{|c|c|c|c|}
\hline 4 & $:$ & …0064 & 293.00 \\
\hline$\vdots \vdots$ & $\therefore$ & .001840 & 203.00 \\
\hline$=$ & $\vdots$ & 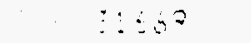 & $=3.00$ \\
\hline$\therefore-$ & & $\therefore \therefore 38$ & 293.00 \\
\hline 5 & $\vdots$ & $\cdots: 9: 08$ & 293.00 \\
\hline . & 3 & .011197 & 293.00 \\
\hline$\therefore$ & ! & $\therefore 6000323$ & 293.00 \\
\hline$\because$ & 3 & 3.0014643 & 293.00 \\
\hline $1-2 \geq 5$ & & $\therefore .000011 ?$ & 293.00 \\
\hline $1 ;-233$ & & 0.0050197 & 293.00 \\
\hline$F \cup=39$ & & 0.0017662 & 293.00 \\
\hline EUSA2 & & 0.0002338 & 293.00 \\
\hline U2:1 & & 0.0000208 & 293.00 \\
\hline FU242 & & 0.0000038 & 293.00 \\
\hline $\operatorname{Am} 241$ & & 0.0000153 & 293.00 \\
\hline$C L$ & 4 & 0.0000003 & 293.00 \\
\hline$\hat{n}$ & 4 & 0.0000020 & 293.00 \\
\hline $\cos 9$ & 1 & 0.0000012 & 293.00 \\
\hline FU 238 & & 0.0000011 & 293.00 \\
\hline HYIIFG & & $1.00000[1-12$ & 293.00 \\
\hline HF 1 & 4 & $1.00000[-12$ & 293.00 \\
\hline LI- 6 & 4 & $1.0000011-12$ & 293.00 \\
\hline $\operatorname{LI} \rightarrow 7$ & 4 & $1-000000-12$ & 291.00 \\
\hline $8 E-9$ & 3 & $1.000000-12$ & 293.00 \\
\hline $8-10$ & 4 & $1.0000001-12$ & 293.00 \\
\hline $8-11$ & 4 & $1.00000[1-12$ & 293.00 \\
\hline$H-14$ & 4 & $1.000000-12$ & 293.00 \\
\hline MG & 4 & $1.0000001-12$ & 293.00 \\
\hline TI & 4 & $1.00000[1-12$ & 293.00 \\
\hline$v$ & 4 & $1.00000[1-12$ & 293.00 \\
\hline $\mathrm{HE} 93$ & 4 & $1.0000001-12$ & 293.00 \\
\hline$A G 107$ & & $1,00000[1-12$ & 293.00 \\
\hline A13109 & & $1.000000-12$ & 293.00 \\
\hline CI! & 1 & $\therefore .000000-12$ & 293.00 \\
\hline EU151 & & $1.0000001-12$ & 293.00 \\
\hline EU153 & & $1.0000011-12$ & 293.00 \\
\hline TA181 & & $\therefore .000000-12$ & 293.00 \\
\hline $\mathrm{FB}$ & 4 & $1.000000-12$ & 293.00 \\
\hline TH232 & & $1.000000-12$ & 293.00 \\
\hline $4-233$ & & $1.00000[1-12$ & 293.00 \\
\hline $11-234$ & & $1.00000 D-12$ & 293.00 \\
\hline$y-236$ & & $1.00000 \mathrm{D}-12$ & 293.00 \\
\hline$i+f 237$ & & $1.00000 \mathrm{D}-12$ & 293.00 \\
\hline$A M=43$ & & $1.000000-12$ & 293.00 \\
\hline & 20000 & $3.35000 E-03$ & $00000 E-05$ \\
\hline & 2 & $\begin{array}{ll}0 & 0\end{array}$ & \\
\hline
\end{tabular}

TABLE A.1. Input Data for $\mathrm{MC}^{2}$ (cont.) 


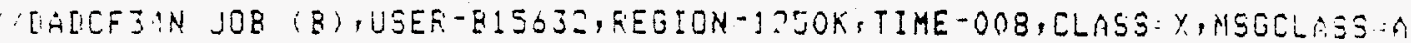
WHAIU URG RIMO10, LINES-030, CARIS :000, SYSTEHA-S195

$i / *$

1:** B15632. IISIYLIE(AICFJANF) *N* IIALICFJAN

$1 / *$

$\therefore / C X$ EXEC FGM=IEBGENEF

ISYSFRIHT IIII SYSOUT $=*$

//SYSUT1 IIL UNIT $=($ FEAII625O),

i) VOL :: (FRIUATE, RETAIH, SER $: 178952), L A B E L=(01, S L)$,

$1 / \quad$ IICB $=\square E N=4, \square I S F-(O L I, K E E F)$,

$1 /$ IISH-C117, B15632,CDUA2262

$/ /$ SYSUT2 [II UNIT=(SASCF),

$1 /$ SCE $=($ RECFN::UBS, LRECL $\div Q, 8 L K S I Z E=6136)$,

$1 / \quad S F A C E=(C Y L,(30,05)$, RLSE $)$,

$1 /$ DISP $=$ ( MEW,PASS),

$1 /$ IISN $=88$ CDVA2262

/SYSIH DII GIINMYY

i*

//ZISIX EXEC ARCSFO12,

$1 / *$

//* FRELIB ='C116.B09202.SDY,M0DLIB',

$1 / *$

$1 /$ VEFSION=1, FORMAT-FMTS,ACCT-NO322

//FT33F001 DD DISF-(SHR),DSN-C117.B15632.CDU12261

//FT33F002 IID UISF-(OLD, DELETE), IISN=88CDUA2262

$/ / F 136 F 001$ DD UHIT: (ALLPERK),

$1 / \quad D C B=($ RECFM $=$ UBS, LRECL $-Y, B L K S I Z E=6136)$,

// SPACE $=(\operatorname{TRK},(1,1))$,

$1 /$ DISP $=(N E W, C A T L G)$,

$1 / \quad D S H=C 117, B 15632$. DADCFF $3 N \cdot V 4281$

$1 / F T 36 F 002$ III UNIT=(ALLFERM),

$1 /$ UCE : (RECF I4 :UBS, LRECL $\because X$, BLKSIZE $=6136)$,

1/ $\quad S P A C E=(T R K,(20,2)$, RLSE $)$,

$1 /$ DISP $=$ (MEH,CATLG),

$/ / \quad$ IISN $=$ C117.B15632. DADCFF3N.V4282

//SYSIM III *

ELOCK $=$ OLI

LIATASET $=$ HCC2FI

DAT ASE T $=$ MCC2F 2

DATASET $=$ MCC2F 3

IIATASET $=$ MCC2F 4

IATASET $=$ HCC2F5

IIATASET $=$ XS . ISO

BLOCK $-S T P O 12$

DATASET $=A$. SIX

01111001

02. CORE

$03 \quad 1$

DATASET $=$ A , MCC2

01

02

03 90000

ZPFF ASSY 13 * HO HOMOG DOUBLE COLUMN DRANER ** B**?(G)<F3

04

06

06

06

06

06

06

06

$\begin{array}{llr} & 0 & 0 \\ C-12 & 4 & 0 \\ 0-16 & 4 & \\ \text { NA23 } & 5 \\ \text { AL27 } & 4 \\ S I & 4 \\ \text { CR } & S \\ \text { MNSS } & S\end{array}$

0.0

$\begin{array}{rrrrrr}0 & 0 & 1 & 0 & 0 & 20 \\ & 0.0 & 0.0 & & 1.35 & 1.35 \\ 0.0000345 & 293.000 & & & \\ 0.0101694 & 293.000 & & & \\ 0.0088114 & 293.000 & & & \\ 0.0000063 & 293.000 & & & \\ 0.0001839 & 293.000 & & & \\ 0.0031620 & 293.000 & & & \\ 0.0002685 & 293.000 & & & \end{array}$

TABLE A.2. Input data for SDX. 


\begin{tabular}{|c|c|c|c|c|}
\hline EE & $\therefore: 1 \equiv 1 \leq 07$ & 233.000 & & \\
\hline$\vdots$ & $.301+175$ & 293.000 & & \\
\hline j: & 60323 & 207.000 & & \\
\hline $40=$ & $\therefore 201244$ & 293.000 & & \\
\hline-2354 & 0.0000113 & 293.000 & & \\
\hline-239.1 & 0.0050163 & 293.000 & & \\
\hline$F 112304$ & 0.0017677 & 293.000 & & \\
\hline $2: 04$ & 0.0002349 & 293.000 & & \\
\hline $0,12: 9$ & 0.0000131 & 293.000 & & \\
\hline 12124 & 0.0000038 & 293.000 & & \\
\hline 2414 & 0.0000175 & 293.000 & & \\
\hline+0.007704 & 0.0 & 0.0 & 0001 & 0102 \\
\hline+0.007976 & 0.0 & 0.0 & 0103 & 0162 \\
\hline+0.006931 & 0.0 & 0.0 & 016.3 & 0222 \\
\hline+0.006722 & 0.0 & 0.0 & 0223 & 0282 \\
\hline+0.0055721 & 0.0 & 0.0 & 0283 & 0312 \\
\hline+0.003510 & 0.0 & 0.0 & 0343 & 0402 \\
\hline+0.003191 & 0.0 & 0.0 & 0403 & 0462 \\
\hline+0.001734 & 0.0 & 0.0 & 0463 & 0522 \\
\hline+0.001680 & 0.0 & 0.0 & 0523 & 0582 \\
\hline+0.000595 & 0.0 & 0.0 & 0583 & 0642 \\
\hline-0.000032 & 0.0 & 0.0 & 0643 & 0702 \\
\hline-0.000538 & 0.0 & 0.0 & 0703 & 0762 \\
\hline+0.000313 & 0.0 & 0.0 & 0763 & 0822 \\
\hline-0.000810 & 0.0 & 0.0 & 0823 & 0882 \\
\hline-0.003126 & 0.0 & 0.0 & 0883 & 0942 \\
\hline-0.003093 & 0.0 & 0.0 & 0943 & 1002 \\
\hline-0.009027 & 0.0 & 0.0 & 1003 & 1062 \\
\hline-0.001920 & 0.0 & 0.0 & 1063 & 1122 \\
\hline-0.004827 & 0.0 & 0.0 & 1123 & 1182 \\
\hline-0.007621 & 0.0 & 0.0 & 1183 & 1242 \\
\hline-0.013989 & 0.0 & 0.0 & 1243 & 1302 \\
\hline-0.021085 & 0.0 & 0.0 & 1303 & 1362 \\
\hline-0.029858 & 0.0 & 0.0 & 1363 & 1422 \\
\hline-0.052053 & 0.0 & 0.0 & 1423 & 1482 \\
\hline-0.100486 & 0.0 & 0.0 & 1483 & 1512 \\
\hline-0.047015 & 0.0 & 0.0 & 1543 & 1602 \\
\hline-0.072890 & 0.0 & 0.0 & 1603 & 1782 \\
\hline-0.036386 & 0.0 & 0.0 & 1783 & 2082 \\
\hline
\end{tabular}

$U-2354$

$U-2384$

FU2391

FU 2404

PU2114

FU2424

Ail2114

$A T H S E T=A$. INTR

\begin{tabular}{|c|c|c|c|c|c|c|c|c|c|}
\hline 2 & $\begin{array}{rl}Z=F F & 0 S 5 Y 13 \\
& 090000\end{array}$ & $\begin{array}{c}* * * \text { DOUBL } \\
0\end{array}$ & LE & COL FUEL & HI & TH B*K(G) & $\angle F 3$ & & \\
\hline 3 & $0 \quad 0$ & 0 & 0 & 0 & 0 & 0 & 0 & 0 & $c$ \\
\hline 4 & 0.00000000 & $1.00000 \mathrm{n}$ & -03 & $1.00000 \mathrm{n}$ & -01 & 0.000000 & 00 & 1.000000 & 100 \\
\hline & $0 \quad 0$ & 0 & 0 & 0 & 0 & & & & \\
\hline & +0.007704 & & & & & 001 & 036 & & \\
\hline & +0.007976 & & & & & 037 & 049 & & \\
\hline & +0.006931 & & & & & 050 & 066 & & \\
\hline 9 & $\begin{array}{l}+0.006722 \\
+0.005721 \\
+0.003510\end{array}$ & & & & & $\begin{array}{l}067 \\
081 \\
094\end{array}$ & $\begin{array}{l}080 \\
093 \\
105\end{array}$ & & \\
\hline & $\begin{array}{l}+0.003491 \\
+0.001734\end{array}$ & & & & & $\begin{array}{l}106 \\
117\end{array}$ & $\begin{array}{l}116 \\
128\end{array}$ & & \\
\hline
\end{tabular}

TABLEA. 2. Input data for SDX (cont.) 


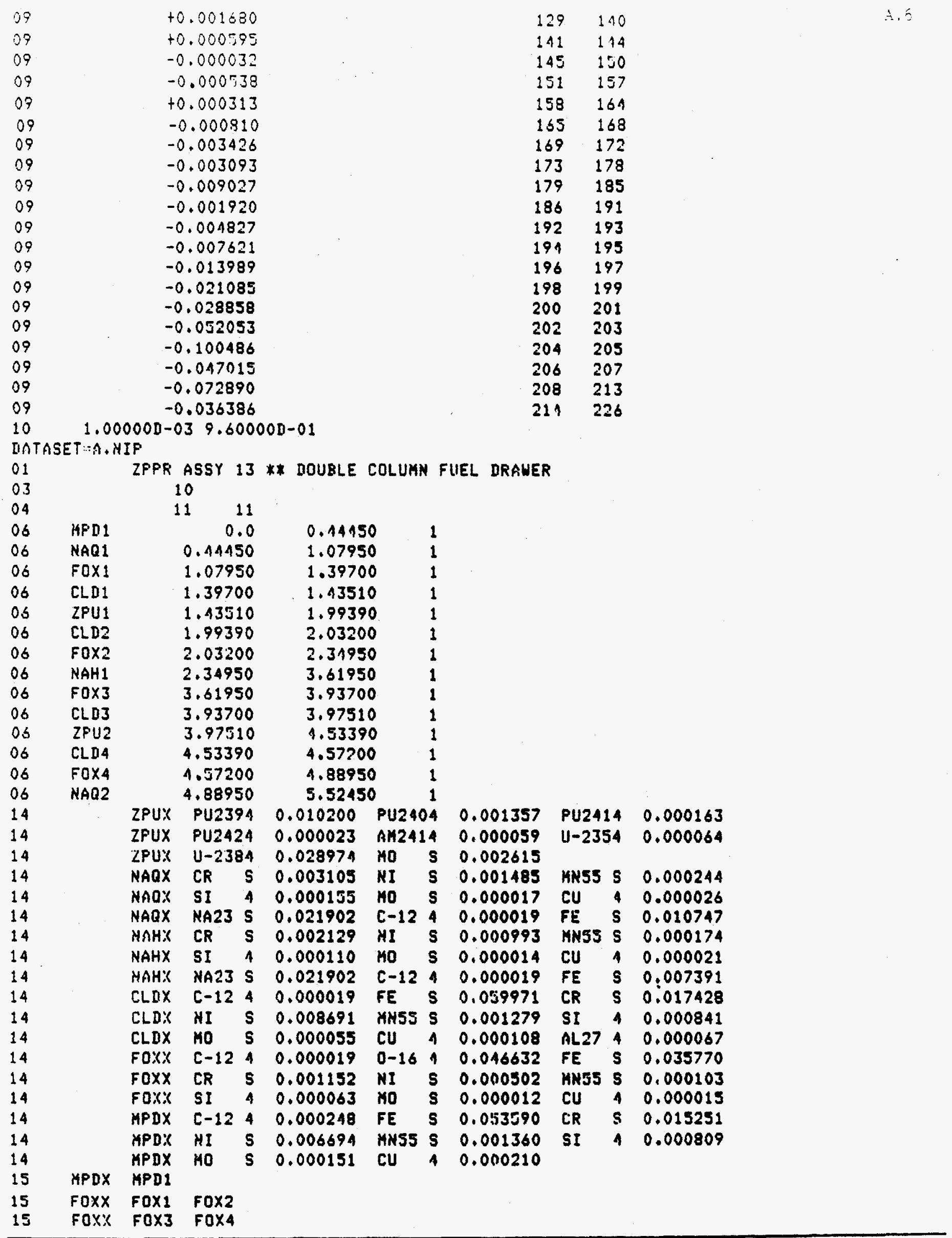

TABLE A.2. Input data for SDX (cont.) 


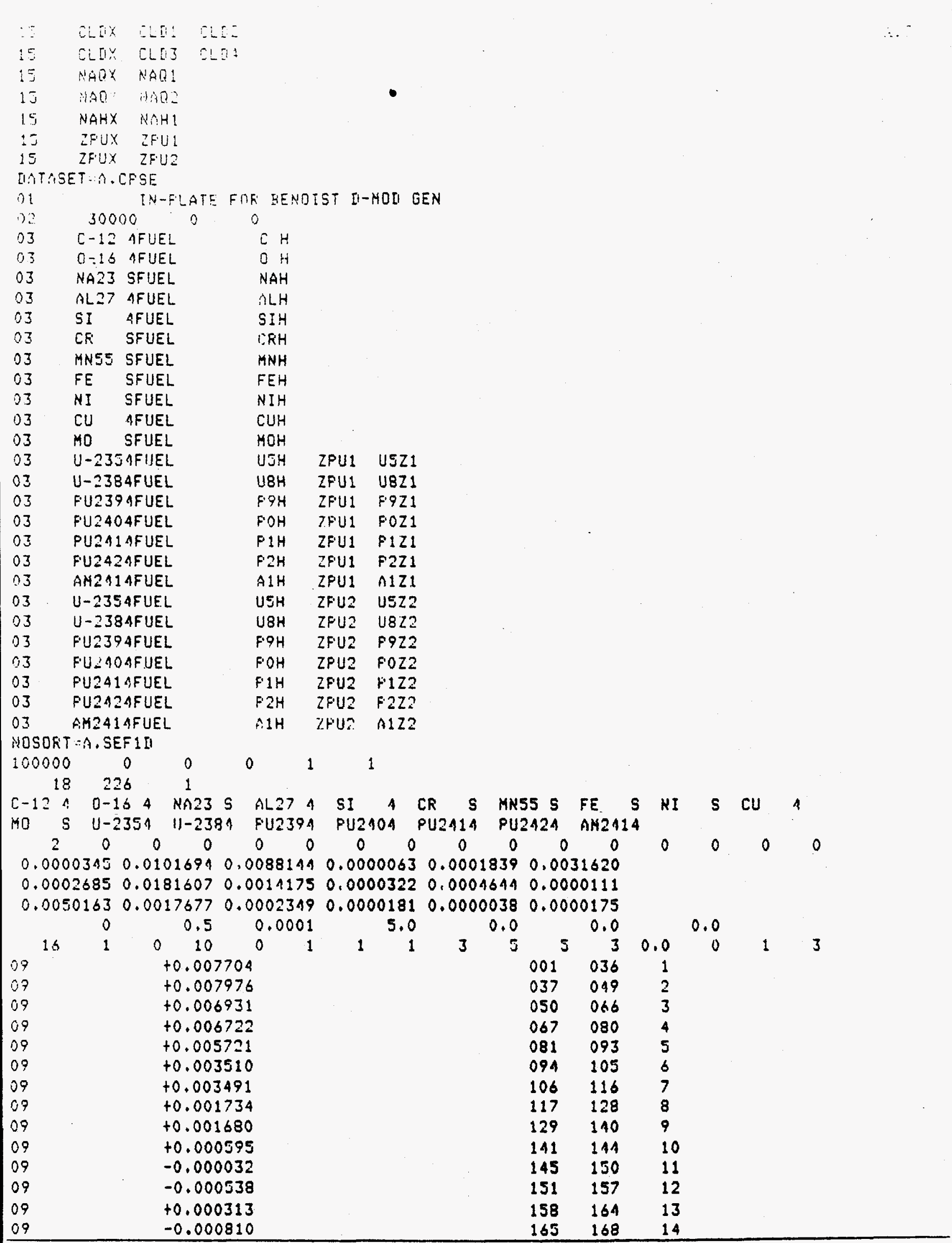

TABLE A.2. Input data for SDX (cont.) 


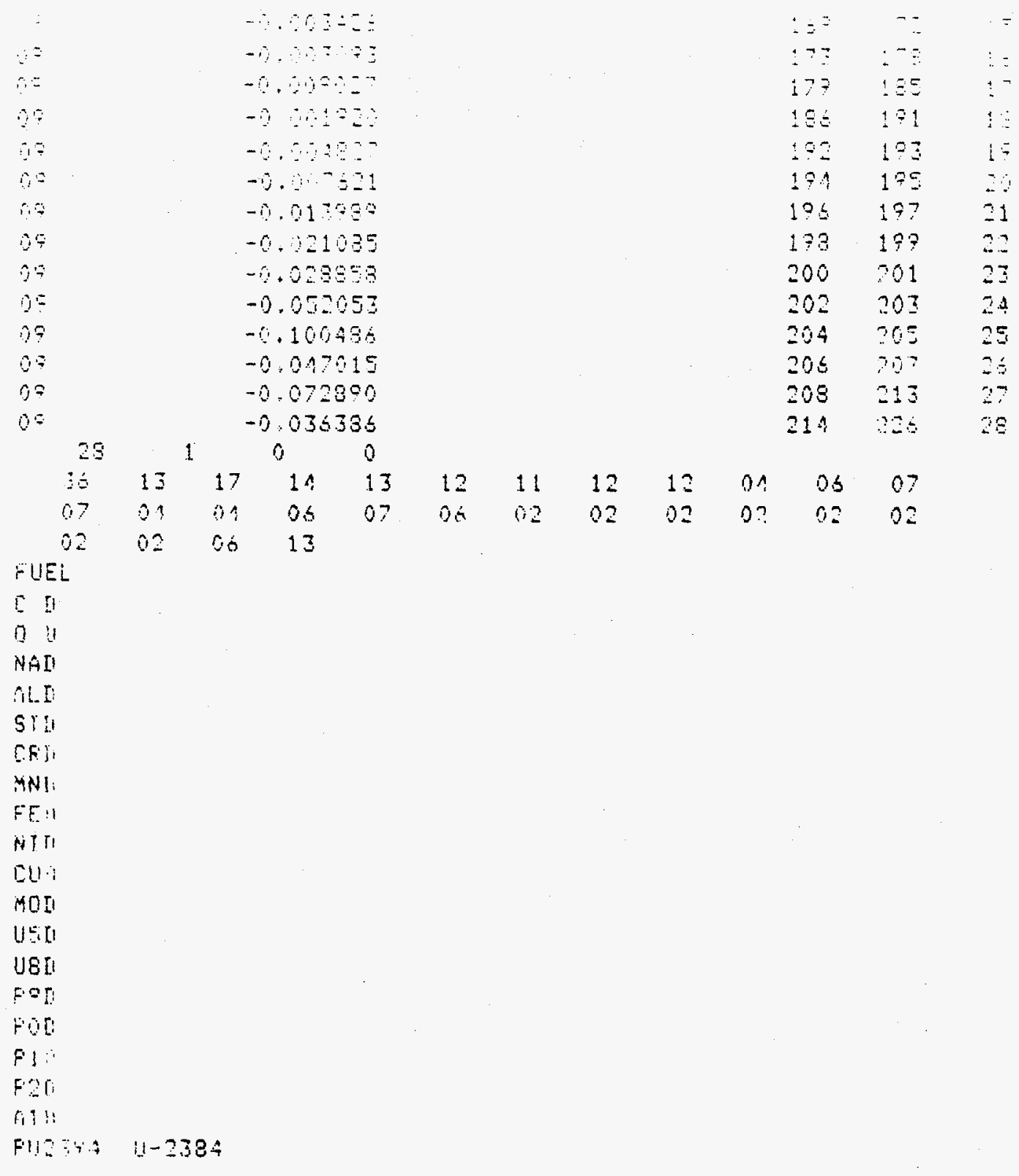

TABLE A.2. Input data for SDX. (cont.) 


\section{APPENDIX B}

The homoganized atom densities used in the ZPPR-13 analysis are presented in this appendix. Tables B.L, B. 2 and B. 3 give the densities for ZPPR-13A,

The atom densities for the control-rod drawers and control-rod-position drawers are given in Table B.4. Drawers without buttons were used in all measurements in $2 P P R-13 A$ 
Homogenized Drawer Compositions for ZPPR-13A $\left(10^{24} \mathrm{At} / \mathrm{cm}^{3}\right)$

Single

Col. Fuel

$0-18$ in.

C $\quad 0.0000335$

0.0139736

$\mathrm{Na} \quad 0.0090188$

$\mathrm{Si} \quad 0.0001579$

Al $\quad 0.0000040$

Mn $\quad \mathbf{0 . 0 0 0 2 3 0 5}$

$\mathrm{Cr} \quad 0.0026941$

Fe $\quad 0.0131312$

$\mathrm{Ni} \quad 0.0011794$

$\mathrm{Cu} \quad 0.0000295$

Mo $\quad 0.0002407$

$235 \mathrm{U} \quad 0.0000126$

$238_{U}$

$238 \mathrm{Pu}$

$23{ }^{9} \mathrm{Pu}$

$240 \mathrm{Pu}$

$241_{\mathrm{Pu}} \mathrm{a}$

$242 \mathrm{Pu}$

$241 \mathrm{Am}^{\mathrm{a}}$

0.0058083

0.0000004

0.0008898

0.0001180

0.0000082

0.0000016

0.0000089
Double Col. Fuel $0-18$ in.

\subsection{5}

0.0101694

0.0088144

0.0001839

0.0000063

0.0002685

0.0031620

0.0181607

0.0014175

0.0000322

0.0004644

0.0000111

0.0050163

0.0000010

0.0017677

0.0002339

0.0000181

0.0000037

0.0000175

\begin{tabular}{c}
\hline \\
\hline $0-18$ in. \\
\hline 0.0000317 \\
0.0222897 \\
0.0041382 \\
0.0001386 \\
0.0000024 \\
0.0001992 \\
0.0023224 \\
0.0082918 \\
0.0009994 \\
0.0000289 \\
0.0000137 \\
0.0000287 \\
0.0131978 \\
-- \\
-- \\
-- \\
--
\end{tabular}

nternal and Radial Blankets

$18-28$ in.

28-29 in.
0.0000317

0.0222897

0.0041382

0.0001386

0,0000024

0.0001992

0.0023224

0.0082918

0.0009994

0.0000289

0.0000137

0.0000287

0.0000317

0.0000003

0.0001391

0.0000025

0.0001998

0.0023337

0.0083338

0.0010043

0.0000289

0.0000137

0.0000636

0.0131978

---

--

-..

-..
0.0041814
0.0291505

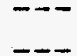

$--$

$\cdots$

$--$
29-31 in.

0.0000319

0.0000003

0.0041335

0.0001397

0.0000025

0.0002540

0.0056522

0.0207125

0.0024565

0.0000291

0.0000137

0.0000434

0.0193358

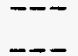

$--$

-..-

$--$
Radial

Refl.

0-36 in. Matrix

0.0002481

---

$--$

0.0006011

$--$

0.0012705

0.0135216

0.0587994

0.0058834

0.0000320

0.0000164

---

$--$

$--$

$---$

$---$

$--$
0.0000186

$---$

0.0000676

0.0001048

0.0011764

0.0042335

0.0004751

0.0000171

0.0000081

$--$

$--$

---

$--$

--

$--$

JAII 3A 29 
TABLE B. 1 . Homogenized Drawer Compositions for ZPPK-13A $\left(10^{24} \mathrm{At} / \mathrm{cm}^{3}\right)$

$(\operatorname{cont}$.

\begin{tabular}{c} 
Axial \\
Bl anket \\
$18-28$ in. \\
\hline
\end{tabular}

C

O

$\mathrm{Na}$

$\mathrm{Si}$

Al

Mn

Cr

$\mathrm{Fe}$

$\mathrm{Ni}$

$\mathrm{Cu}$

Mo

$235 \mathrm{U}$

$238 \mathrm{U}$

$238 \mathrm{Pu}$

$239_{\mathrm{Pu}}$

$240 \mathrm{Pu}$.

$241 \mathrm{Pu}$

$242 \mathrm{Pu}$

$241 \mathrm{Am}$

apecayed to 6-1-82.

0.0142813

0.0092968

0.0001444

0.0000028

0.0002061

0.0024051

0.0123703

0.0010349

0.0000279

0.0000127

0.0000179

0.0081644

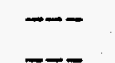

$--$

$--$
Ax ial

Bl anke t

18-28 in.

0.0000619

0.0088277

0.0090981

0.0002397

0.0000027

0.0003731

0.0041119

0.0147299

0.0018039

0.0000279

0.0000128

0.0000179

0.0081649
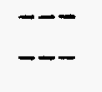

$-\infty$

$-\infty$
Ax ial

Bl anket

28-29 in b

0.0000331

0.0054643

0.0094191

0.0001439

0.0000028

0.0002053

0.0024004

0.0123621

0.0010325

0.0000278

0.0000127

0.0000320

0.0145622
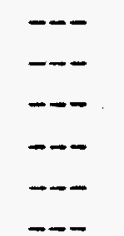

Ax ial

$B l$ anket

28-29 in. c

0.0000617

0.0000006

0.0089800

0.0002403

0.0000028

0.0003739

0.0041313

0.0147976

0.0018140

0.0000280

0.0000127

0. 0000318

0.0145321

$---$

$--$

$-\infty$

bAxial blanket behind double column fuel.

$c_{A x}$ ial blanket behind single column fuel.

Ax ial

Bl ank 1

29-31 in. b

0.0000570

0.0054449

0.0093394

0.0002238

0.0000028

0.0003243

0.0040282

0.0184370

0.0017752

0.0000471

0.0000226

0.0000217

0.0096843

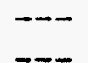

$--$

29-31 in. $c$

0.0000858

0.0000006

0.0089800

0.0003212

0.0000028

0.0004944

0. 0057751

0.0209428

0.0025642

0.0000473

0.0000227

0.0000217

0.0097138

$--$

$--$
Iron

Bl ock

Re $\mathrm{fl}$.

0.0005874

$--$

0.0001115

$--$

0.0006791

0.0019487

0.0768471

0.0007863

0.0000256

0.0000127

$--$

-

$--$

- -

$\cdots$

-

$-$
Steel

Refl : ...

$0.000218 \%$

$\ldots$

0.0008374

$--$

0.0014769

0.0145968

0.0517614

0.0064583

0.0000185

0.0000090

$---$

-.

$\cdots$

$---$

$--1$

$--$

JA I I 3B 30 
The results are grouped according to the different traverses, radial or axial and special experiments. For convenience, some results are duplicated among the tables.

Tables C.1 and C.2: Traverses at the $x$ and $y$ axes for all four reactions.

Tables C. 3 to C.6: Comparison of $235 \mathrm{U}$ in symmetric positions at the axes, at $30^{\circ}$ and at $60^{\circ}$ to the axes.

Table C.7:

$235_{\mathrm{U}}$ fission at $15^{\circ}, 45^{\circ}, 75^{\circ}$ to the $\mathrm{x}$-axis.

Table C.8:

Special measurements in the radial reflector.

Table C.9: $235_{\mathrm{U}}$ fission foil for fission chamber calibration.

Tables C.10 and C.11: Axial traverses in 147-42 and 147-27.

Tables C. 12 to C. 14: Axial traverses for $235_{U}$ fission.

Tables C.15 and C.16: Reaction rate ratios at the axes.

Tables C.17 and C.18: Reaction rate ratios from the axial traverses. 
TABLE C.L. ZPPR-13A : REACTION RATES MEASURED ALONG THE X-AXIS

\begin{tabular}{|c|c|c|c|c|c|c|c|c|c|}
\hline \multirow[b]{2}{*}{ MATRIX } & & \multicolumn{2}{|c|}{$239 \mathrm{PU}(\mathrm{N}, \mathrm{F})$} & \multicolumn{2}{|c|}{$235 \mathrm{U}(\mathrm{N}, \mathrm{F})$} & \multicolumn{2}{|c|}{$238 \mathrm{U}(\mathrm{N}, \mathrm{G})$} & \multicolumn{2}{|c|}{$238 U(N, F)$} \\
\hline & & ------ & $-\infty-\infty$ & $---\infty-\cdots$ & $---\infty$ & & --- & & \\
\hline POSITION & ZONE & EXP. A & $C / E$ & EXP. A & $C / E$ & EXP. A & $C / E$ & EXP. A & $C / E$ \\
\hline------ & $-\cdots$ & $-\cdots--$ & 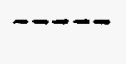 & $---\infty$ & $-\infty-\infty$ & $---\infty$ & ---- & $-\cdots--$ & $-\cdots$ \\
\hline $149 \quad 50$ & $\mathrm{CB}$ & 4.260 & 0.973 & 5.131 & 1.006 & 0.6138 & 1.036 & 0.0185 & 0.877 \\
\hline 14850 & CB & 4.357 & 0.951 & 5.140 & 1.004 & 0.6111 & 1.041 & 0.0189 & 0.859 \\
\hline 14949 & $C B$ & 4.341 & 0.954 & 5.180 & 0.995 & 0.6113 & 1.040 & 0.0185 & 0.878 \\
\hline 14849 & $\mathrm{CB}$ & 4.248 & 0.975 & 5.164 & 0.999 & 0.5065 & 1.048 & 0.0189 & 0.860 \\
\hline 14749 & $\mathrm{CB}$ & 4.473 & 0.959 & 5.306 & 1.000 & 0.6268 & 1.050 & 0.0220 & 0.883 \\
\hline 14748 & $\mathrm{CB}$ & 4.588 & 0.966 & 5.429 & 1.003 & 0.6521 & 1.041 & 0.0255 & 0.897 \\
\hline $148 \quad 47$ & $\mathrm{CB}$ & 4.669 & 0.980 & 5.524 & 1.011 & 0.6649 & 1.053 & 0.0289 & 0.919 \\
\hline 14846 & $\mathrm{CB}$ & 5.095 & 0.979 & 5.981 & 0.996 & 0.7207 & 1.049 & 0.0378 & 1.065 \\
\hline 14845 & $\mathrm{CB}$ & 5.610 & 0.975 & 6.324 & 1.003 & 0.7739 & 1.057 & 0.0612 & 1.052 \\
\hline 14844 & $\mathrm{CB}$ & 6.118 & 0.980 & 6.557 & 1.020 & 0.8217 & 1.051 & 0.1006 & 1.045 \\
\hline 14744 & Fl $\mathrm{S}$ & 6.146 & 0.958 & 6.492 & 1.021 & 0.8763 & 1.034 & 0.1421 & 0.948 \\
\hline 14743 & FI & 6.434 & 0.971 & 6.684 & 1.004 & 0.8544 & 1.067 & 0.2089 & 0.895 \\
\hline 14742 & $F 1 S$ & 6.717 & 0.999 & 6.915 & 1.022 & 0.9121 & 1.053 & 0.2009 & 0.958 \\
\hline 14741 & Fl & 6.895 & 0.974 & 7.235 & 0.996 & 0.9277 & 1.060 & 0.2250 & 0.893 \\
\hline 14740 & Fl S & 7.023 & 0.968 & 7.576 & 1.012 & 1.0090 & 1.048 & 0.1666 & 0.911 \\
\hline 14739 & B1 & 7.222 & 0.984 & 7.987 & 1.012 & 1.0130 & 1.046 & 0.0951 & 1.054 \\
\hline 14738 & BI & 7.350 & 0.992 & 8.155 & 1.018 & 1.0330 & 1.055 & 0.0910 & 1.072 \\
\hline $147 \quad 37$ & $\mathrm{Bl}$ & 7.559 & 0.998 & 8.198 & 1.022 & 1.0330 & 1.059 & 0.1267 & 1.050 \\
\hline 14736 & F2 & 7.567 & 0.997 & 7.977 & 1.020 & 1.0250 & 1.086 & 0.2419 & 0.884 \\
\hline 14735 & F2 S & 7.709 & 1.015 & 7.940 & 1.045 & 1.0560 & 1.060 & 0.2397 & 0.946 \\
\hline 14734 & F2 & 7.654 & 1.007 & 7.942 & 1.029 & 1.0120 & 1.094 & 0.2618 & 0.919 \\
\hline 14733 & $\mathrm{~F} 2 \mathrm{~S}$ & 7.403 & 1.017 & 7.901 & 1.047 & 1.0500 & 1.078 & 0.2020 & 0.931 \\
\hline 14732 & B2 & 7.343 & 1.016 & 7.936 & 1.058 & 1.0210 & 1.079 & 0.1102 & 1.045 \\
\hline 14731 & B2 & 6.985 & 1.040 & 7.797 & 1.061 & 1.0050 & 1.083 & 0.0846 & 1.118 \\
\hline 14730 & B2 & 6.847 & 1.048 & 7.551 & 1.062 & 0.9617 & 1.093 & 0.1028 & 1.106 \\
\hline 14729 & F3 & 6.764 & 1.022 & 7.061 & 1.058 & 0.9143 & 1.117 & 0.2050 & 0.919 \\
\hline 14728 & F3 S & 6.611 & 1.045 & 6.765 & 1.069 & 0.8874 & 1.089 & 0.1988 & 1.032 \\
\hline 14727 & F3 C & 6.431 & 1.039 & 6.315 & 1.070 & 0.7932 & 1.140 & 0.2261 & 0.981 \\
\hline 14726 & F3 S & 5.818 & 1.047 & 5.897 & 1.066 & 0.7578 & 1.099 & 0.1838 & 1.030 \\
\hline 14725 & F3 & 5.102 & 1.059 & 5.257 & 1.071 & 0.6627 & 1.135 & 0.1773 & 0.977 \\
\hline 14724 & F3 S & 4.388 & 1.023 & 4.646 & 1.062 & 0.6026 & 1.109 & 0.1125 & 0.979 \\
\hline 14723 & RB & 3.628 & 1.037 & 3.934 & 1.083 & 0.4870 & 1.125 & 0.0493 & 1.112 \\
\hline 14722 & $\mathrm{RB}$ & 2.911 & 1.016 & 3.255 & 1.069 & 0.3947 & 1.116 & 0.0262 & 1.049 \\
\hline 14721 & $\mathrm{RB}$ & 2.339 & 1.009 & 2.667 & 1.065 & 0.3114 & 1.109 & 0.0141 & 1.004 \\
\hline 14720 & $\mathrm{RB}$ & 2.095 & 0.967 & 2.321 & 1.057 & 0.2540 & 1.088 & 0.0079 & 0.952 \\
\hline
\end{tabular}

A UNITS OF 10-18 REACTIONS PER ATOM PER SECOND AT A REACTOR POWER OF APPROXIMATELY 1 WATT. THE 239PU FOILS WERE LOCATED AT 90.8 MM FROM THE MIDPLANE, THE 235U FOILS AT 63.1 MM AND THE $238 \mathrm{U}$ FOILS AT $77.0 \mathrm{MM}$.

B STATISTICAL UNCERTAINTIES FOR MEASUREMENT OF $238 \mathrm{U}$ FISSION RANGE FROM $3 \%$ TO $7 \%$ WITH PENETRATION IN THE CENTRAL BLANKET AND FROM 3\% TO 20\% WITH PENETRATION IN THE RADIAL BLANKET.

C AXIAL TRAVERSE LOCATION, ALL FOILS WERE AT 77.0 MM FROM THE MIDPLANE 
TABLE C.2. ZPPR-13A : REACTION RAIES MEASURED ALONG THE Y-AXIS

\begin{tabular}{|c|c|c|c|c|c|c|c|c|c|}
\hline \multirow{3}{*}{$\begin{array}{c}\text { MATRIX } \\
\text { POSITION }\end{array}$} & \multirow{3}{*}{ ZONE } & \multicolumn{2}{|c|}{$239 \mathrm{PU}(\mathrm{N}, \mathrm{F})$} & \multicolumn{2}{|c|}{$235 \mathrm{U}(\mathrm{N}, \mathrm{F})$} & \multicolumn{2}{|c|}{$238 U(N, G)$} & \multicolumn{2}{|c|}{$238 \mathrm{U}(\mathrm{N}, E) B$} \\
\hline & & ----- & $-\cdots-\infty$ & $-\cdots---$ & $-\infty-\infty$ & $-\infty-\infty-1$ & --- & & ---- \\
\hline & & EXP. A & $C / E$ & EXP. A & $C / E$ & EXP. A & $C / E$ & EXP. A & $C / E$ \\
\hline$---\infty-\infty$ & $-\cdots-\infty$ & $-\cdots-$ & --- & ---- & ---- & ----- & $--\infty$ & ----- & $\cdots--$ \\
\hline 14950 & $\mathrm{CB}$ & 4.260 & 0.973 & 5.131 & 1.006 & 0.6138 & 1.036 & 0.0185 & 0.877 \\
\hline 14949 & $C B$ & 4.341 & 0.954 & 5.180 & 0.995 & 0.6113 & 1.040 & 0.0185 & 0.878 \\
\hline 14850 & $C B$ & 4.357 & 0.951 & 5.140 & 1.004 & 0.6111 & 1.041 & 0.0189 & 0.859 \\
\hline 14849 & $\mathrm{CB}$ & 4.248 & 0.975 & 5.164 & 0.999 & 0.6065 & 1.048 & 0.0189 & 0.860 \\
\hline 14749 & $\mathrm{CB}$ & 4.473 & 0.959 & 5.306 & 1.000 & 0.6268 & 1.050 & 0.0220 & 0.883 \\
\hline 14748 & $\mathrm{CB}$ & 4.588 & 0.966 & 5.429 & 1.003 & 0.6521 & 1.041 & 0.0255 & 0.897 \\
\hline 14649 & $\mathrm{CB}$ & 4.802 & 0.953 & 5.523 & 1.011 & 0.6701 & 1.045 & 0.0284 & 0.940 \\
\hline 14549 & $C B$ & 5.145 & 0.967 & 5.894 & 1.008 & 0.7207 & 1.046 & 0.0382 & 1.056 \\
\hline 14449 & CB & 5.597 & 0.971 & 6.266 & 1.006 & 0.7858 & 1.033 & 0.0595 & 1.082 \\
\hline 14349 & $\mathrm{CB}$ & 6.035 & 0.983 & 6.558 & 1.009 & 0.8195 & 1.042 & 0.1003 & 1.046 \\
\hline 14348 & FIS & 6.002 & 0.970 & 6.511 & 1.008 & 0.8761 & 1.023 & 0.1443 & 0.926 \\
\hline 14248 & Fl & 6.376 & 0.971 & 6.643 & 1.001 & 0.8472 & 1.067 & 0.2124 & 0.873 \\
\hline 14148 & $\mathrm{E} \perp \mathrm{S}$ & 6.639 & 0.985 & 6.909 & 1.012 & 0.9130 & 1.035 & 0.2065 & 0.908 \\
\hline $140 \quad 48$ & F1 & 6.727 & 0.976 & 7.078 & 1.000 & 0.9152 & 1.056 & 0.2233 & 0.867 \\
\hline 13948 & FIS & 6.807 & 0.972 & 7.439 & 1.004 & 0.9928 & 1.039 & 0.1631 & 0.900 \\
\hline 13848 & B1 & 6.954 & 0.992 & 7.820 & 1.003 & 0.9812 & 1.049 & 0.0891 & 1.084 \\
\hline 13748 & B 1 & 7.202 & 0.978 & 7.922 & 1.012 & 1.0070 & 1.045 & 0.0886 & 1.069 \\
\hline 13648 & $\mathrm{Bl}$ & 7.413 & 0.979 & 7.960 & 1.012 & 1.0090 & 1.043 & 0.1247 & 1.031 \\
\hline 13548 & F2 & 7.459 & 0.972 & 7.699 & 1.011 & 1.0080 & 1.055 & 0.2407 & 0.873 \\
\hline 13448 & F2 S & 7.469 & 0.995 & 7.733 & 1.022 & 1.0170 & 1.048 & 0.2247 & 0.956 \\
\hline 13348 & F2 & 7.479 & 0.972 & 7.563 & 1.021 & 0.9811 & 1.068 & 0.2542 & 0.884 \\
\hline 13248 & F2 S & 7.142 & 0.989 & 7.626 & 1.022 & 1.0250 & 1.043 & 0.1905 & 0.908 \\
\hline 13148 & B 2 & 6.921 & 1.005 & 7.576 & 1.036 & 0.9715 & 1.061 & 0.0995 & 1.053 \\
\hline 13048 & B2 & 6.659 & 1.010 & 7.294 & 1.053 & 0.9422 & 1.074 & 0.0762 & 1.124 \\
\hline 12948 & B2 & 6.522 & 1.012 & 7.136 & 1.038 & 0.9074 & 1.069 & 0.0934 & 1.099 \\
\hline 12848 & F3 S & 6.407 & 0.995 & 6.679 & 1.043 & 0.8988 & 1.054 & 0.1683 & 0.954 \\
\hline 12748 & F3 & 6.350 & 0.982 & 6.236 & 1.046 & 0.7929 & 1.104 & 0.2176 & 0.912 \\
\hline 12648 & F3 S & 5.952 & 1.009 & 5.962 & 1.043 & 0.7733 & 1.068 & 0.1915 & 0.969 \\
\hline 12548 & E3 & 5.434 & 1.009 & 5.475 & 1.030 & 0.6838 & 1.093 & 0.1954 & 0.953 \\
\hline 12448 & F 3 & 4.787 & 1.008 & 4.842 & 1.040 & 0.6163 & 1.092 & 0.1677 & 0.923 \\
\hline 12348 & F3 $\mathrm{S}$ & 4.071 & 1.002 & 4.323 & 1.040 & 0.5616 & 1.085 & 0.1032 & 0.964 \\
\hline 12248 & $\mathrm{RB}$ & 3.382 & 1.013 & 3.667 & 1.060 & 0.4566 & 1.094 & 0.0471 & 1.037 \\
\hline 12148 & $R B$ & 2.768 & 0.975 & 3.034 & 1.047 & 0.3713 & 1.082 & 0.0230 & 1.068 \\
\hline 12048 & RB & 2.215 & 0.978 & 2.506 & 1.041 & 0.2935 & 1.078 & 0.0129 & 0.990 \\
\hline 11948 & $R B$ & 1.933 & 0.979 & 2.187 & 1.045 & 0.2385 & 1.071 & 0.0084 & 0.812 \\
\hline
\end{tabular}

A UNITS OF 10-18 REACTIONS PER ATOM PER SECOND AT A REACTOR POWER OF APPROXIMATELY 1 WATT. THE 239PU FOILS WERE LOCATED AT 90.8 MM FROM THE MIDPLANE, THE 235U FOILS AT 63.1 MM AND THE 238U FOILS AT $77.0 \mathrm{MM}$.

B STATISTICAL UNCERTAINTIES FOR MEASUREMENT OF 238U FISSION RANGE FROM $3 \%$ TO $7 \%$ WITH PENETRATION IN THE CENTRAL BLANKET AND FROM 3\% TO 20\% WITH PENETRATION IN THE RADIAL BLANKET. 
TABLE C.3. ZPPR-13A: MEASUREMENTS OF 235U EISSION RATES IN SYMMTRIC POSITIONS ALOHG THE X-AXIS

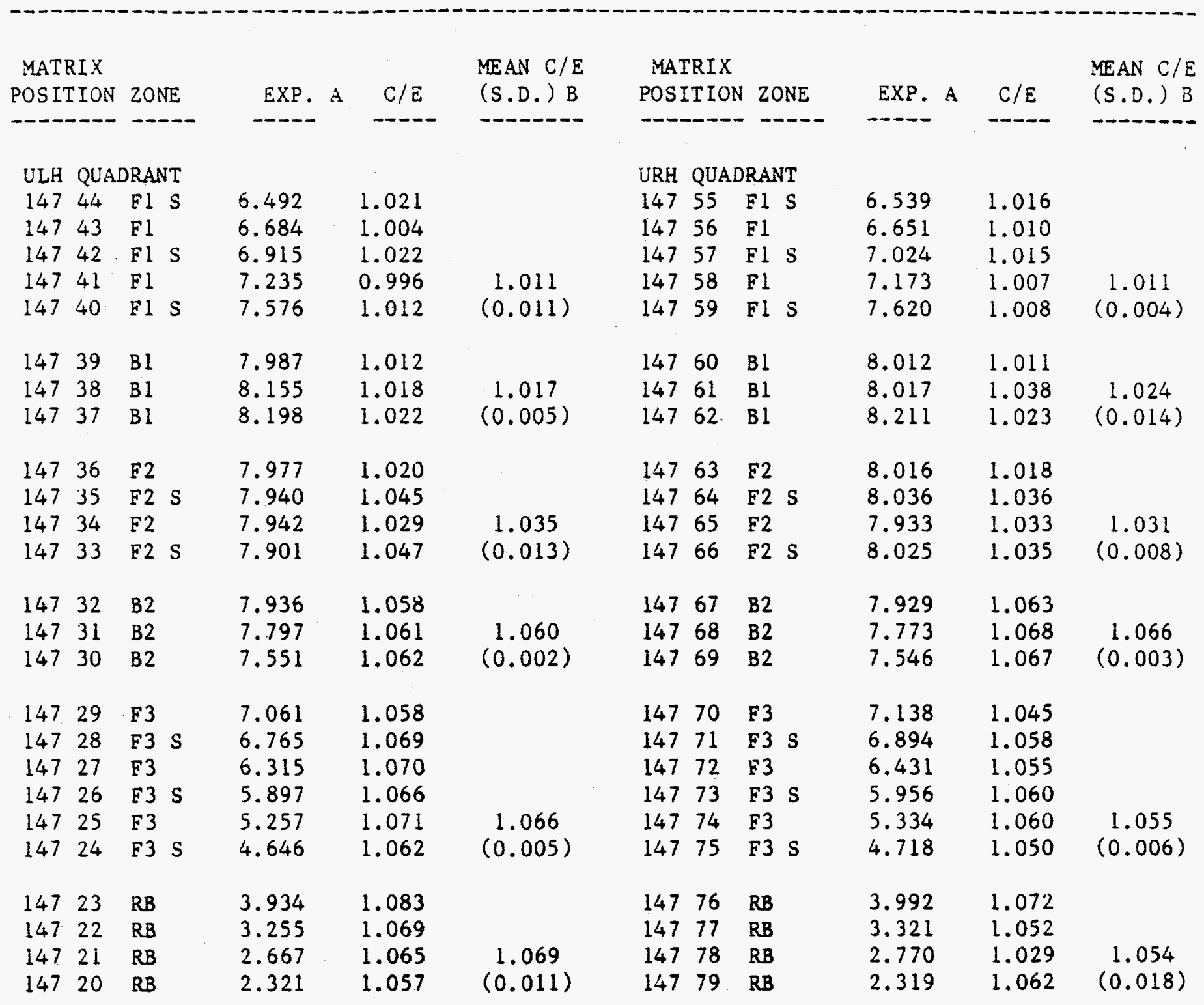

A UNITS OF 10-18 FISSIONS PER ATOM PER SECOND AT A REACTOR POWER OF APPROXIMATELY 1 WATT. THE 235U FOILS WERE LOCATED 63.1 MM FROM THE MIDPLANE. ULH QUADRANT=UPPER-LEFTHAND QUADRANT OF THE ZPPR HALF-1, ETC.

B STANDARD DEVIATION OF THE C/E DISTRIBUTION 
TABLE C. 4 . ZPPR-13A: MEASUREMENTS OF 235U FISSION RATES IN SYMMETRIC POSITIONS ALONG THE Y-AXIS

\begin{tabular}{|c|c|c|c|c|c|c|c|c|c|}
\hline \multicolumn{2}{|l|}{ MATRIX } & \multicolumn{2}{|c|}{ A } & MEAN C/E & \multicolumn{2}{|c|}{ MATRIX } & \multicolumn{2}{|c|}{ A } & \multirow{2}{*}{$\begin{array}{l}\text { MEAN C/E } \\
\text { (S.D.) }\end{array}$} \\
\hline POS IT ION & ZONE & EXP. & $C / E$ & (S.D.) B & POS IT IO & N ZONE & EXP. & $C / E$ & \\
\hline$-n-\infty-\infty$ & $--\infty$ & --- & $\cdots$ & $-\cdots$ & - & $-\cdots$ & $-\infty$ & $-\infty$ & \\
\hline ULH QUA & DRANT & & & & LLH QUA & DRANT & & & \\
\hline 14348 & Fl S & 6.511 & 1.008 & & $154 \quad 48$ & $F 1 S$ & 6.419 & 1.019 & \\
\hline $142 \quad 48$ & Fl & 6.643 & 1.001 & & 15548 & Fl & 6.589 & 1.006 & \\
\hline 14148 & F1 S & 6.909 & 1.012 & & 15648 & F $1 \mathrm{~S}$ & 6.819 & 1.022 & \\
\hline $140 \quad 48$ & Fl & 7.078 & 1.000 & 1.005 & 15748 & $F 1$ & 6.982 & 1.010 & 1.013 \\
\hline 13948 & $\mathrm{~F} 1 \mathrm{~S}$ & 7.439 & 1.004 & $(0.005)$ & 15848 & F I S & 7.369 & 1.010 & $(0.007)$ \\
\hline 13848 & B 1 & 7.820 & 1.003 & & 15948 & B 1 & 7.623 & 1.025 & \\
\hline 13748 & B 1 & 7.922 & 1.012 & 1.009 & 16048 & B1 & 7.809 & 1.022 & 1.029 \\
\hline 13648 & Bl & 7.960 & 1.012 & $(0.005)$ & 16148 & B 1 & 7.722 & 1.039 & $(0.009)$ \\
\hline 13548 & F 2 & 7.699 & 1.011 & & 16248 & F2 & 7.479 & 1.037 & \\
\hline $134 \quad 48$ & F2 S & 7.733 & 1.022 & & 16348 & F2 S & 7.531 & 1.045 & \\
\hline 13348 & F2 & 7.563 & 1.021 & 1.019 & $164 \quad 48$ & F2 & 7.465 & 1.031 & 1.039 \\
\hline 13248 & F2 S & 7.626 & 1.022 & $(0.005)$ & 16548 & F2 S & 7.440 & 1.044 & $(0.007)$ \\
\hline 13148 & B 2 & 7.576 & 1.036 & & 16648 & B2 & 7.372 & 1.060 & \\
\hline 13048 & B 2 & 7.294 & 1.053 & 1.042 & 16748 & B2 & 7.237 & 1.057 & 1.062 \\
\hline 12948 & B 2 & 7.136 & 1.038 & $(0.009)$ & 16848 & B2 & 6.901 & 1.070 & $(0.007)$ \\
\hline $128 \quad 48$ & F3 $\mathrm{S}$ & 6.679 & 1.043 & & 16948 & F3 S & 6.694 & 1.037 & \\
\hline 12748 & F 3 & 6.236 & 1.046 & & 17048 & F 3 & 6.260 & 1.040 & \\
\hline $126 \quad 48$ & F3 $\mathrm{S}$ & 5.962 & 1.043 & & 17148 & F3 S & 6.033 & 1.038 & \\
\hline 12548 & F3 & 5.475 & 1.030 & & 17248 & F3 & 5.362 & 1.048 & \\
\hline $124 \quad 48$ & F3 & 4.842 & 1.040 & 1.040 & 17348 & E3 & 4.748 & 1.057 & 1.046 \\
\hline 12348 & F3 $\mathrm{S}$ & 4.323 & 1.040 & $(0.006)$ & 17448 & F3 S & 4.248 & 1.054 & $(0.009)$ \\
\hline $122 \quad 48$ & RB & 3.667 & 1.060 & & $175 \quad 48$ & RB & 3.656 & 1.059 & \\
\hline 12148 & RB & 3.034 & 1.047 & & 17648 & RB & 2.987 & 1.060 & \\
\hline 12048 & RB & 2.506 & 1.041 & 1.048 & 17748 & $R B$ & 2.455 & 1.058 & 1.061 \\
\hline 11948 & $R B$ & 2.187 & 1.045 & $(0.008)$ & 17848 & RB & 2.136 & 1.066 & $(0.004)$ \\
\hline
\end{tabular}

A UNITS OF 10-18 FISSIONS PER ATOM PER SECOND AT A REACTOR POWER OF APPROXIMATELY

1 WATT. THE 235U FOILS WERE LOCATED 63.1 MM FROM THE MIDPLANE. ULH QUADRANT=UPPER-LEFTHAND QUADRANT OF THE ZPPR HALF-1, ETC.

B STANDARD DEVIATION OF THE C/E DISTRIBUTION 
TABLE C.5 - ZPPR-13A: MEASUREMENTS OF 235U FISSION RATES IN SYMMETRIC POSITIONS AT 30-DEGREES TO THE X-AXIS

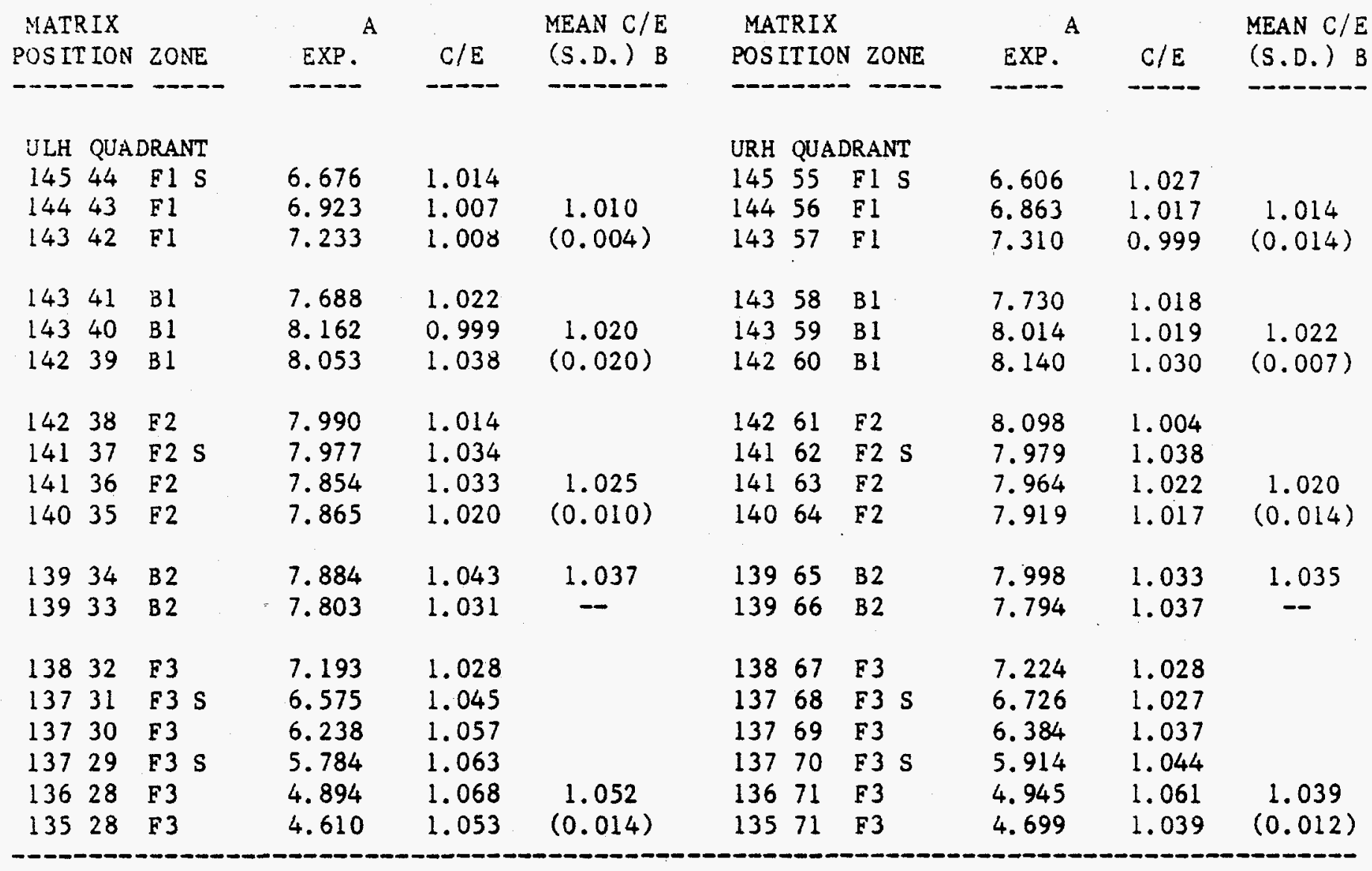

A UNITS OF 10-18 FISSIONS PER ATOM PER SECOND AT A REACTOR POWER OF APPROXIMATELY 1 WATT. THE 235U FOILS WERE LOCATED 63.1 MM FROM THE MIDPLANE. ULH QUADRANT=UPPER-LEFTHAND QUADRANT OF THE ZPPR HALF-1, ETC.

B STANDARD DEVIATION OF THE C/E DISTRIBUTION 
TABLE C.6. ZPPR-13A: MEASUREMENTS OF 235U FISSION RATES IN SYMMETRIC POSITIONS AT 60-DEGREES TO THE X-AXIS

\begin{tabular}{|c|c|c|c|c|c|c|c|c|c|}
\hline $\begin{array}{l}\text { MATR IX } \\
\text { POS IT ION }\end{array}$ & ZONE & \multicolumn{2}{|c|}{ A } & $\begin{array}{l}\text { MEAN C/E } \\
\text { (S.D.) B }\end{array}$ & \multicolumn{2}{|l|}{ MATRIX } & \multicolumn{2}{|c|}{ A } & $\begin{array}{l}\text { MEAN C/E } \\
\text { (S.D.) B }\end{array}$ \\
\hline$\cdots-\cdots$ & $\cdots-$ & $\cdots-\cdots$ & $\cdots$ & $\cdots-\cdots$ & $\cdots-\cdots$ & 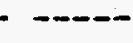 & $\cdots$ & --- & \\
\hline ULH QUAD & DRANT & & & & URH QUAI & DRANT & & & \\
\hline 14346 & F 1 & 6.610 & 0.999 & & 14353 & E 1 & 6.667 & 0.992 & \\
\hline 14246 & $\mathrm{Fl} \mathrm{S}$ & 6.880 & 1.010 & 1.004 & 14253 & F1 S & 6.934 & 1.003 & 0.993 \\
\hline 14145 & F 1 & 7.070 & 1.004 & $(0.006)$ & 14154 & F1 & 7.216 & 0.985 & $(0.009)$ \\
\hline 14044 & B1 & 7.730 & 1.008 & & 14055 & B1 & 7.716 & 1.012 & \\
\hline 13944 & BI & 8.007 & 1.003 & 1.010 & 13955 & B 1 & 7.934 & 1.013 & 1.011 \\
\hline 13843 & B1 & 8.071 & 1.018 & $(0.008)$ & 13856 & B 1 & 8.175 & 1.007 & $(0.003)$ \\
\hline 13743 & F2 & 7.844 & 1.011 & & 13756 & F2 & 7.986 & 0.995 & \\
\hline 13642 & $\mathrm{~F} 2 \mathrm{~s}$ & 7.807 & 1.035 & & 13657 & $\mathrm{~F} 2 \mathrm{~S}$ & 7.937 & 1.021 & \\
\hline 13542 & F2 & 7.704 & 1.027 & 1.021 & 13557 & F2 & 7.720 & 1.028 & 1.013 \\
\hline $134 \quad 41$ & F 2 & 7.745 & 1.009 & $(0.013)$ & 13458 & F2 & 7.791 & 1.007 & $(0.015)$ \\
\hline 13340 & B2 & 7.798 & 1.026 & 1.032 & 13359 & B2 & 7.759 & 1.036 & 1.039 \\
\hline 13240 & B2 & 7.507 & 1.037 & -- & 13259 & B2 & 7.499 & 1.042 & - \\
\hline 13140 & F3 S & 7.263 & 1.016 & & 13159 & F3 S & 7.284 & 1.017 & \\
\hline 13039 & E3 & 6.515 & 1.030 & & 13059 & F 3 & 6.739 & 1.034 & \\
\hline 12938 & F 3 & 6.028 & 1.052 & & 12961 & F3 & 6.134 & 1.038 & \\
\hline 12838 & F3 S & 5.593 & 1.057 & & 12861 & F3 S & 5.673 & 1.047 & \\
\hline 12737 & F3 & 4.761 & 1.055 & 1.044 & 12762 & F3 & 4.837 & 1.044 & 1.036 \\
\hline 12736 & F3 & 4.446 & 1.055 & $(0.017)$ & 12763 & F3 & 4.538 & 1.037 & $(0.011)$ \\
\hline
\end{tabular}

A UNITS OF 10-18 FISSIONS PER ATOM PER SECOND AT A REACTOR POWER OF APPROXIMATELY 1 WATT. THE 235U FOILS WERE LOCATED 63.1 MM FROM THE MIDPLANE. URH QUADRANT=UPPER-LEFTHAND QUADRANT OF THE ZPPR HALF-1, ETC.

B STANDARD DEVIATION OF THE C/E DISTRIBUTION. 
TABLE C.7. ZPPR-L3A: MEASUREMENTS OF 235U EISSION RATES AT 15-,45- AND 75-DEGREES TO THE X-AXIS

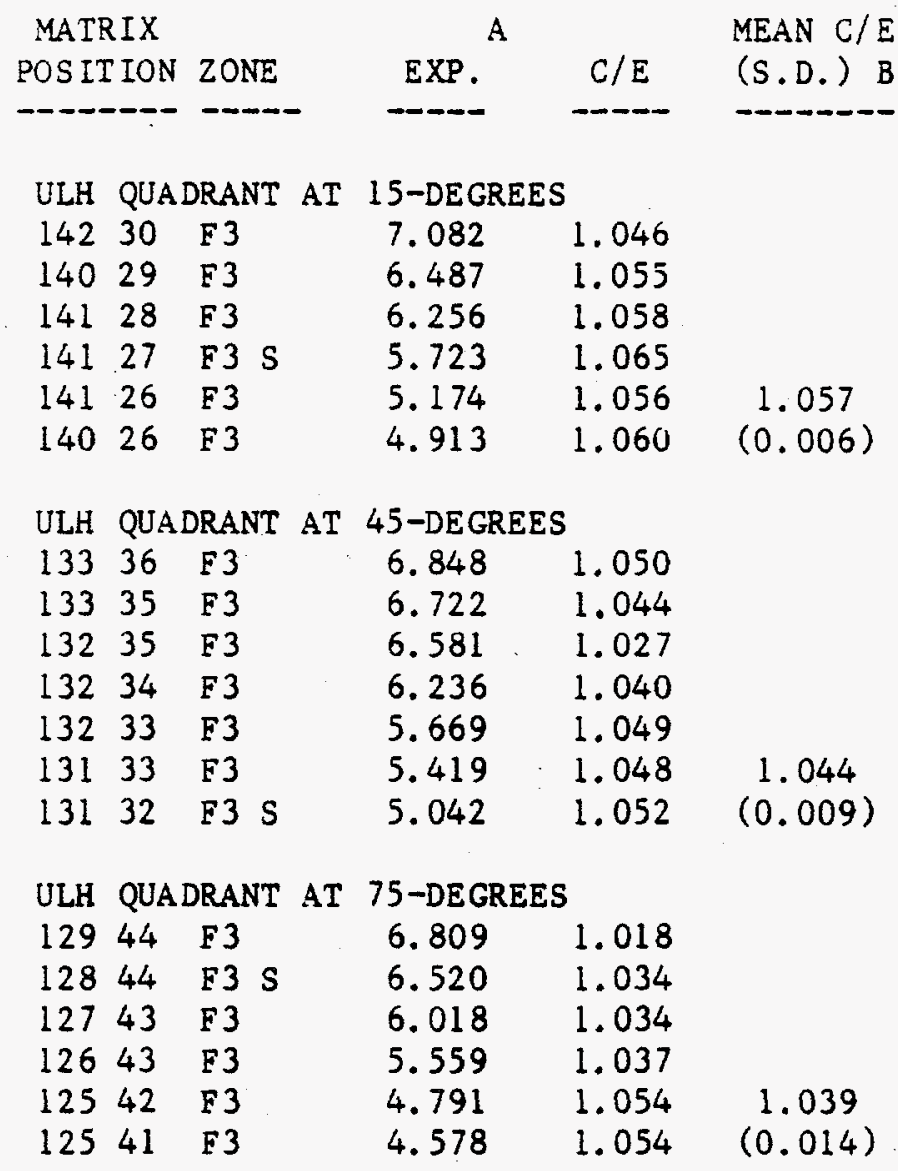

A UNITS OF 10-18 FISSIONS PER ATOM PER SECOND AT A REACTOR POWER OF APPROXIMATELY 1 WATT. THE 235U FOILS WERE LOCATED 63.1 MM FROM THE MIDPLANE. ULH QUADRANT =UPPER-LEFT-HAND QUADRANT OF THE ZPPR HALF-1, ETC. B STANDARD DEVIATION OF THE C/E DISTRIBUTION. 
TABLE C.8. 2PPR-13A: SPECLAL 235U $(N, F)$ MEASUREMENTS IN THE RADIAL REFLECTOR

\begin{tabular}{|c|c|c|c|c|c|c|c|c|c|}
\hline \multirow[b]{2}{*}{$\begin{array}{l}\text { MATRIX } \\
\text { POSITION }\end{array}$} & \multicolumn{4}{|c|}{$X$-AXIS POSITIONS } & \multirow[b]{2}{*}{ MATRIX } & & \multicolumn{3}{|c|}{ Y-AXIS POSIIIONS } \\
\hline & $2 O \mathrm{NE}^{\mathrm{A}}$ & $2, M$ & EXP. & $C / E$ & & $20 N E^{A}$ & $\mathrm{Z}, \mathrm{MM}$ & EXP. & $C / E$ \\
\hline$-\cdots$ & --- & $\ldots$ & $-\infty-\infty$ & $-\infty-$ & $-\infty-\infty-\infty$ & --- & $-\infty-\infty$ & ---- & --- \\
\hline 14817 & $R R T$ & 12.3 & 1.537 & 1.059 & 11648 & RR T & 12.3 & 1.230 & 1.041 \\
\hline 14817 & RR $T$ & 26.2 & 1.524 & 1.066 & 11648 & RR $T$ & 26.2 & 1.231 & 1.038 \\
\hline 14817 & RR T & 40.0 & 1.527 & 1.062 & 11648 & RR $T$ & 40.0 & 1.236 & 1.032 \\
\hline 14817 & RR B & 12.3 & 1.528 & 1.069 & $116 \quad 48$ & RR B & 12.3 & 1.488 & 1.139 \\
\hline 14817 & RR B & 26.2 & 1.523 & 1.070 & 11648 & RR B & 26.2 & 1.487 & 1.138 \\
\hline 14817 & RR B & 40.0 & 1.538 & 1.057 & 11648 & $\mathrm{RR} B$ & 40.0 & 1.503 & 1.124 \\
\hline 18148 & & 12.3 & 1.598 & 1.072 & 14882 & RR $\mathbf{T}$ & 12.3 & 1.554 & 1.053 \\
\hline 18148 & $R R T$ & 26.2 & 1.590 & 1.076 & 14882 & $\mathbf{R R} \mathbf{T}$ & 26.2 & 1.549 & 1.054 \\
\hline 18148 & $R R T$ & 40.0 & 1.581 & 1.080 & $148 \quad 82$ & $R R T$ & 40.0 & 1.552 & 1.050 \\
\hline 18148 & RR $B$ & 12.3 & 1.350 & 0.955 & 14882 & RR B & 12.3 & 1.553 & 1.056 \\
\hline $181 \quad 48$ & RR B & 26.2 & 1.330 & 0.968 & $148 \quad 82$ & $R R B$ & 26.2 & 1.551 & 1.056 \\
\hline 18148 & RR B & 40.0 & 1.333 & 0.964 & 14882 & RR $B$ & 40.0 & 1.548 & 1.055 \\
\hline
\end{tabular}

A ZONE RR =RADIAL REFLECTOR. T = IN FOIL HOLDER LOCATION NEAR TOP OF DRAWER (12.1 MM ABOVE DRAWER CENTRE). B = IN FOIL HOLDER LOCATION NEAR BOTTOM OF DRAWER (12.1 MM BELOW DRAWER CENTR B UNITS OF 10-18 FISSIONS PER ATOM PER SECOND AT A REACTOR POWER OF APPROXIMATELY 1 WATT. 
TABLE C.9. ZPPR-13A: 235U EISSION MEASURED IN POSITIONS SMMMETRIC TO IN-CORE EISSION CHAMBERS

\begin{tabular}{|c|c|c|c|c|c|c|c|c|c|}
\hline MATR IX & ZONE & \multicolumn{2}{|l|}{ A } & $\begin{array}{l}\text { MEAN C/E } \\
(\text { S.D.) B }\end{array}$ & \multicolumn{2}{|l|}{ MATRIX } & \multicolumn{2}{|l|}{ A } & \multirow{2}{*}{$\begin{array}{l}\text { MEAN C/E } \\
\text { (S.D.) B }\end{array}$} \\
\hline - & - & 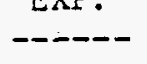 & $--\cdots$ & - & $\ldots$ & $-\infty$ & - & --- & \\
\hline $150 \quad 51$ & $C B$ & 5.343 & 1.006 & & 12651 & F3 S & 5.793 & 1.045 & \\
\hline 24451 & $\mathrm{CB}$ & 6.391 & 1.005 & 1.004 & 22657 & E3 S & 5.231 & 1.031 & \\
\hline $250 \quad 45$ & $C B$ & 6.333 & 1.002 & $(0.002)$ & $\begin{array}{ll}232 & 63 \\
132 & 69\end{array}$ & $\begin{array}{l}\text { F3 S } \\
\text { F3 }\end{array}$ & $\begin{array}{l}6.621 \\
4.295\end{array}$ & $\begin{array}{l}1.032 \\
1.027\end{array}$ & \\
\hline 14356 & F 1 & 7.133 & 1.000 & & 23869 & F 3 & 6.441 & 1.044 & \\
\hline $250 \quad 57$ & $\mathrm{~F} \perp \mathrm{S}$ & 6.988 & 1.017 & & 14469 & F 3 & 7.277 & 1.019 & \\
\hline 25651 & $\mathrm{~F} 1 \mathrm{~S}$ & 6.797 & 1.009 & & 15075 & F3 S & 4.816 & 1.058 & \\
\hline 15645 & F 1 & 7.053 & 0.992 & 1.000 & 15669. & F3 & 6.960 & 1.037 & \\
\hline $144 \quad 45$ & F1 & 6.675 & 0.984 & $(0.013)$ & $\begin{array}{ll}262 & 69 \\
268 & 63\end{array}$ & $\begin{array}{l}\text { E3 } \\
\text { F3 }\end{array}$ & $\begin{array}{l}5.650 \\
5.572\end{array}$ & $\begin{array}{l}1.060 \\
1.060\end{array}$ & \\
\hline 13851 & B1 & 7.846 & 1.002 & & 16857 & F3 & 6.649 & 1.029 & \\
\hline 15657 & 31 & 7.668 & 1.035 & & 17451 & F3 S & 4.404 & 1.042 & \\
\hline 15039 & BI & 8.003 & 1.007 & & 16845 & F 3 & 6.888 & 1.016 & \\
\hline 24439 & B1 & 8.035 & 1.026 & 1.018 & 26839 & F3 & 6.236 & 1.038 & \\
\hline 23845 & B1 & 7.903 & 1.021 & $(0.014)$ & $\begin{array}{ll}168 & 33 \\
262 & 33\end{array}$ & $\begin{array}{l}\text { F3 } \\
\text { F3 }\end{array}$ & $\begin{array}{l}4.493 \\
6.694\end{array}$ & $\begin{array}{l}1.041 \\
1.039\end{array}$ & \\
\hline 23251 & F2 S & 7.660 & 1.009 & & 25627 & F3 S & 5.859 & 1.066 & \\
\hline 23857 & F2 S & 8.000 & 1.008 & & $150 \quad 27$ & F 3 & 6.319 & 1.068 & \\
\hline 24463 & F2 & 7.980 & 1.019 & & $244 \quad 27$ & F 3 & 6.058 & 1.051 & \\
\hline $150 \quad 63$ & E2 & 7.969 & 1.019 & & 13827 & F3 & 4.888 & 1.057 & \\
\hline 25663 & F2 & 7.897 & 1.023 & & 13233 & F 3 & 5.669 & 1.049 & \\
\hline 26257 & F2 & 7.708 & 1.022 & & 12639 & F3 & 4.692 & 1.027 & 1.042 \\
\hline 16251 & F2 & 7.665 & 1.005 & & 22645 & F 3 & 5.586 & 1.033 & $(0.015)$ \\
\hline $262 \quad 45$ & F2 & 7.614 & 1.018 & & & & & & \\
\hline 25639 & F2 S & 8.065 & 1.016 & & & & & & \\
\hline $250 \quad 33$ & F2 S & 7.905 & 1.040 & 1.019 & & & & & \\
\hline 13839 & F2 & 7.780 & 1.027 & $(0.010)$ & & & & & \\
\hline & & & & & 22057 & $\mathrm{RB}$ & 2.138 & 1.093 & \\
\hline 13257 & B2 & 7.661 & 1.024 & & $126 \quad 63$ & RB & 3.820 & 1.060 & \\
\hline 13863 & B2 & 8.030 & 1.035 & & 23375 & RB & 3.050 & 1.056 & \\
\hline $250 \quad 69$ & B2 & 7.570 & 1.050 & & 27463 & RB & 2.464 & 1.059 & \\
\hline $.160 \quad 63$ & B2 & 8.051 & 1.024 & & $162 \quad 27$ & RB & 4.033 & 1.074 & 1.069 \\
\hline 26851 & B2 & 7.031 & 1.056 & & 23227 & $\mathrm{RB}$ & 2.764 & 1.069 & $(0.014)$ \\
\hline $162 \quad 39$ & B2 & 7.800 & 1.041 & & & & & & \\
\hline 15633 & B2 & 7.816 & 1.049 & & & & & & \\
\hline 14433 & B2 & 7.977 & 1.047 & & & & & & \\
\hline 23833 & B 2 & 7.501 & 1.038 & & & & & & \\
\hline 23239 & B2 & 7.268 & 1.032 & 1.039 & & & & & \\
\hline 13245 & B2 & 7.665 & 1.030 & $(0.011)$ & & & & & \\
\hline
\end{tabular}

A UNITS OF 10-18 FISSIONS PER ATOM PER SECOND AT A REACTOR POWER OF APPROXIMATELY

1 WATT. THE 235U FOILS WERE LOCATED 63.1 MM FROM THE MIDPLANE.

B STANDARD DEVIATION OF THE C/E DISTRIBUTION FOR THE SELECTED GROUPS. 
TABLE C. 10. ZPPR-13A: AXIAL TRAVERSES IN MATRIX 147-42

\begin{tabular}{|c|c|c|c|c|c|c|c|c|c|c|}
\hline \multirow{2}{*}{$\begin{array}{c}\text { MATR IX } \\
\text { POS IT ION }\end{array}$} & \multirow{2}{*}{ ZONE } & \multirow[b]{2}{*}{$\mathrm{Z}, \mathrm{MM}$} & \multicolumn{2}{|c|}{$239 \mathrm{PU}(\mathrm{N}, \mathrm{F})$} & \multicolumn{2}{|c|}{$235 \mathrm{U}(\mathrm{N}, \mathrm{F})$} & \multicolumn{2}{|c|}{$238 \mathrm{U}(\mathrm{N}, \mathrm{G})$} & \multicolumn{2}{|c|}{$2380(N, F)$} \\
\hline & & & EXP.A & $C / E$ & EXP.A & $\mathrm{C} / \mathrm{E}$ & EXP.A & $\mathrm{C} / \mathrm{E}$ & EXP. A & $\mathrm{C} / \mathrm{E}$ \\
\hline 14742 & F1S & 63.1 & -- & -- & 6.918 & 1.029 & -- & -- & -- & -- \\
\hline 14742 & El $\mathrm{S}$ & 77.0 & 6.717 & 0.999 & 6.915 & 1.022 & 0.9121 & 1.053 & 0.2009 & 0.958 \\
\hline 14742 & F1 S & 127.8 & 6.541 & 0.993 & 6.714 & 1.019 & 0.8990 & 1.035 & 0.1932 & 0.964 \\
\hline 14742 & F1 S & 204.0 & 6.085 & 0.983 & 6.229 & 1.014 & 0.8317 & 1.033 & 0.1689 & 1.013 \\
\hline 14742 & F1 S & 280.2 & 5.372 & 0.982 & 5.489 & 1.019 & 0.7355 & 1.037 & 0.1555 & 0.960 \\
\hline 14742 & F1 S & 331.0 & 4.848 & 0.972 & 4.902 & 1.028 & 0.6783 & 1.015 & 0.1413 & 0.926 \\
\hline 14742 & F1 S & 381.8 & 4.265 & 0.963 & 4.472 & 1.001 & 0.5987 & 1.025 & 0.1168 & 0.928 \\
\hline 14742 & Fl $\mathrm{S}$ & 432.6 & 3.571 & 0.983 & 3.956 & 1.005 & 0.5364 & 1.017 & 0.0888 & 0.908 \\
\hline 14742 & $\mathbf{A B}$ & 483.4 & 3.307 & 0.975 & 3.602 & 1.023 & 0.4450 & 1.062 & 0.0456 & 0.954 \\
\hline 14742 & $\overline{A B}$ & 534.2 & 2.801 & 0.988 & 3.197 & 1.018 & 0.3860 & 1.059 & 0.0252 & $0.960 \mathrm{~B}$ \\
\hline $147 \quad 42$ & $\mathbf{A B}$ & 610.4 & 2.169 & 0.965 & 2.517 & 1.003 & 0.2935 & 1.052 & 0.0122 & $0.851 \mathrm{~B}$ \\
\hline 14742 & $\mathbf{A B}$ & 686.6 & 1.592 & 0.951 & 1.815 & 1.016 & 0.2107 & 1.041 & 0.0060 & $0.773 \mathrm{~B}$ \\
\hline CORE RE & IION & & & $\begin{array}{c}0.982 \\
(0.012)\end{array}$ & & $\begin{array}{c}1.017 \\
(0.010)\end{array}$ & & $\begin{array}{c}1.031 \\
(0.013)\end{array}$ & & $\begin{array}{c}0.951 \\
(0.035)\end{array}$ \\
\hline
\end{tabular}

A UNITS OF 10-18 REACTIONS PER ATOM PER SECOND AT A REACTOR POWER OF APPROXIMATELY 1 WATT.

B STATISTICAL UNCERTAINT IES ARE $3 \%$ TO $20 \%$ FOR 238 U FISSION AT THESE LOCATIONS 
TABLE C. 11. 2PPR-13A: AXIAL TRAVERSES IN MATRIX 147-27

\begin{tabular}{|c|c|c|c|c|c|c|c|c|c|c|}
\hline \multirow[b]{2}{*}{$\begin{array}{c}\text { MATRIX } \\
\text { POSITION }\end{array}$} & \multirow[b]{2}{*}{ ZONE } & \multirow[b]{2}{*}{$\mathrm{Z}, \mathbf{M M}$} & \multicolumn{2}{|c|}{$239 \mathrm{PU}(\mathrm{N}, \mathrm{F})$} & \multicolumn{2}{|c|}{$235 \mathrm{U}(\mathrm{N}, \mathrm{F})$} & \multicolumn{2}{|c|}{$238 \mathrm{U}(\mathrm{N}, \mathrm{G})$} & \multicolumn{2}{|c|}{$2380(N, E)$} \\
\hline & & & EXP.A & $\mathrm{C} / \mathrm{E}$ & EXP.A & $\mathrm{C} / \mathrm{E}$ & EXP.A & $C / E$ & EXP.A & $C / E$ \\
\hline------ & $--\infty$ & $-\infty-$ & $-\infty-\infty$ & ---- & $-\cdots$ & $--\cdots$ & ----- & --- & $---\infty$ & ----- \\
\hline 14727 & F 3 & 77.0 & 6.431 & 1.039 & 6.315 & 1.070 & 0.7932 & 1.140 & 0.2261 & 0.981 \\
\hline 14727 & F 3 & 127.8 & 6.271 & 1.031 & 6.120 & 1.069 & 0.7729 & 1.133 & 0.2244 & 0.956 \\
\hline 14727 & F 3 & 204.0 & 5.706 & 1.043 & 5.664 & 1.065 & 0.7176 & 1.126 & 0.2038 & 0.966 \\
\hline 14727 & F 3 & 280.2 & 5.167 & 1.012 & 5.074 & 1.050 & 0.6467 & 1.107 & 0.1801 & 0.953 \\
\hline 14727 & F 3 & 331.0 & 4.587 & 1.016 & 4.564 & 1.048 & 0.5803 & 1.112 & 0.1600 & 0.937 \\
\hline 14727 & F 3 & 381.8 & 3.984 & 1.016 & 4.025 & 1.050 & 0.5243 & 1.094 & 0.1324 & 0.938 \\
\hline 14727 & F 3 & 432.6 & 3.361 & 1.023 & 3.554 & 1.045 & 0.4474 & 1.138 & 0.0990 & 0.930 \\
\hline 14727 & $\mathbf{A B}$ & 483.4 & 3.050 & 1.009 & 3.190 & 1.074 & 0.4117 & 1.070 & 0.0445 & $1.056 \mathrm{~B}$ \\
\hline 14727 & $\mathrm{AB}$ & 534.2 & 2.522 & 1.039 & 2.860 & 1.054 & 0.3593 & 1.062 & 0.0247 & $1.064 \mathrm{~B}$ \\
\hline 14727 & $\mathbf{A B}$ & 610.4 & 1.983 & 0.993 & 2.204 & 1.061 & 0.2690 & 1.073 & 0.0125 & $0.894 \mathrm{~B}$ \\
\hline 14727 & $\mathbf{A B}$ & 686.6 & 1.419 & 0.999 & 1.625 & 1.057 & 0.1925 & 1.070 & 0.0077 & $0.636 \mathrm{~B}$ \\
\hline CORE RE & GION & & & $\begin{array}{c}1.026 \\
(0.012)\end{array}$ & & $\begin{array}{c}1.057 \\
(0.011)\end{array}$ & & $\begin{array}{c}1.121 \\
(0.017)\end{array}$ & & $\begin{array}{c}0.952 \\
(0.018)\end{array}$ \\
\hline
\end{tabular}

A UNITS OF 10-18 REACTIONS PER ATOM PER SECOND AT A REACTOR POWER OF APPROXIMATELY 1 WATT.

B STATISTICAL UNCERTAINTIES ARE 3\% TO 20\% FOR 238U FISSION AT THESE LOCATIONS 
TABLE C. 12. ZPPR-13A: AXIAL TRAVERSES FOR 235U(N,F) IN FUEL RING 3 NEAR TO THE AXES

\begin{tabular}{|c|c|c|c|c|c|c|c|c|}
\hline \multirow[b]{2}{*}{$\mathrm{Z}, \mathrm{MM} \mathrm{A}$} & \multicolumn{2}{|c|}{$\begin{array}{l}\text { MATR IX POS ITION } \\
147-27\end{array}$} & \multicolumn{2}{|c|}{$\begin{array}{l}\text { MATRIX POSITION } \\
147-72\end{array}$} & \multicolumn{2}{|c|}{$\begin{array}{c}\text { MATRIX POS ITION } \\
126-48\end{array}$} & \multicolumn{2}{|c|}{$\begin{array}{l}\text { MATRIX POS ITION } \\
171-48\end{array}$} \\
\hline & EXP. B & $C / E$ & EXP. B & $C / E$ & EXP. B & $\mathrm{C} / \mathrm{E}$ & EXP. B & $\mathrm{C} / \mathrm{E}$ \\
\hline & \multicolumn{2}{|c|}{ ULH QUADRANT } & \multicolumn{2}{|c|}{ URH QUADRANT } & \multicolumn{2}{|c|}{ ULH QUADRANT } & \multicolumn{2}{|c|}{ LLH QUADRANT } \\
\hline 12.9 & 6.437 & 1.069 & 6.556 & 1.054 & 5.971 & 1.033 & 6.121 & 1.041 \\
\hline 12.9 & 6.435 & 1.072 & 6.567 & 1.055 & 6.098 & 1.032 & 5.956 & 1.053 \\
\hline 12.9 & 6.398 & 1.080 & 6.566 & 1.057 & 6.173 & 1.036 & 5.882 & 1.045 \\
\hline 63.1 & -- & -- & 6.478 & 1.056 & 5.962 & 1.043 & 5.923 & 1.047 \\
\hline 77.0 & 6.315. & 1.070 & 6.431 & 1.055 & 5.873 & 1.031 & 6.033 & 1.038 \\
\hline 127.8 & 6.120 & 1.069 & 6.211 & 1.058 & 5.647 & 1.038 & 5.789 & 1.047 \\
\hline 204.0 & 5.664 & 1.065 & 5.731 & 1.057 & 5.193 & 1.042 & 5.320 & 1.051 \\
\hline 280.2 & 5.074 & 1.050 & 5.082 & 1.053 & 4.611 & 1.038 & 4.721 & 1.048 \\
\hline 331.0 & 4.564 & 1.048 & 4.612 & 1.042 & 4.165 & 1.033 & 4.247 & 1.048 \\
\hline 381.8 & 4.025 & 1.050 & 4.065 & 1.044 & 3.705 & 1.029 & 3.774 & 1.045 \\
\hline 432.6 & 3.554 & 1.045 & 3.626 & 1.029 & 3.257 & 1.035 & 3.345 & 1.042 \\
\hline $\begin{array}{l}\text { CORE RE } \\
\text { (S.D.) }\end{array}$ & ION MEAN & $\begin{array}{c}1.062 \\
(0.012)\end{array}$ & & $\begin{array}{c}1.051 \\
(0.009)\end{array}$ & & $\begin{array}{c}1.035 \\
(0.004)\end{array}$ & & $\begin{array}{c}1.046 \\
(0.004)\end{array}$ \\
\hline
\end{tabular}

A THE THREE MEASUREMENTS AT $Z=12.9$ MM WERE RESPECTIVELY 12.1 MM ABOVE THE DRAWER CENTRE, AT THE DRAWER CENTRE AND 12.9 MM BELOW THE DRAWER CENTRE ( ALONG THE Y-DIMENSION). MATRIX POSITIONS 126-48 AND 171-48 WERE SINGLE-FUEL-COLUMN DRAWERS.

B UNITS OF 10-18 FISSIONS PER ATOM PER SECOND AT A REACTOR POWER OF APPROXIMATELY 1 WATT. ULH QUADRANT = UPPER-LEFT-HAND QUADRANT OF ZPPR HALF-ONE ETC. 
TABLE C.13. 2PPR-13A: AXIAL TRAVERSES FOR 235U(N,E) IN EUEL RING 3 AT 30-DEGREES TO THE X-AXIS

\begin{tabular}{|c|c|c|c|c|c|c|c|c|}
\hline \multirow[b]{2}{*}{ Z, M A } & \multicolumn{2}{|c|}{$\begin{array}{c}\text { MATRIX POSITION } \\
137-31\end{array}$} & \multicolumn{2}{|c|}{$\begin{array}{l}\text { MATRIX POSITION } \\
137-68\end{array}$} & \multicolumn{2}{|c|}{$\begin{array}{l}\text { MATRIX POSITION } \\
160-68\end{array}$} & \multicolumn{2}{|c|}{$\begin{array}{c}\text { MATRIX POSITION } \\
160-31\end{array}$} \\
\hline & EXP. B & $C / E$ & $\begin{array}{ll}\text { EXP. B } \\
-\end{array}$ & $\mathrm{C} / \mathrm{E}$ & EXP. E & C/E & $\begin{array}{ll}\text { EXP. } B \\
-\end{array}$ & $\mathrm{C} / \mathrm{E}$ \\
\hline & \multicolumn{2}{|c|}{ ULH QUADRANT } & \multicolumn{2}{|c|}{ URH QUADRANT } & \multicolumn{2}{|c|}{ LRH QUADRANT } & \multicolumn{2}{|c|}{ LLH QUADRANT } \\
\hline 12.9 & 6.664 & 1.050 & 6.704 & 1.049 & 6.839 & 1.044 & 6.663 & 1.064 \\
\hline 12.9 & 6.732 & 1.050 & 6.811 & 1.042 & 6.831 & 1.038 & 6.658 & 1.058 \\
\hline 12.9 & 6.803 & 1.046 & 6.811 & 1.049 & 6.667 & 1.053 & 6.540 & 1.066 \\
\hline 63.1 & 6.640 & 1.052 & - & - & - & - & -- & -- \\
\hline 77.0 & 6.575 & 1.045 & 6.726 & 1.027 & 6.665 & 1.053 & 6.486 & 1.074 \\
\hline 127.8 & 6.341 & 1.049 & -- & -- & -- & -- & -- & - \\
\hline 204.0 & 5.877 & 1.044 & - & -- & -- & -- & -- & - \\
\hline 280.2 & 5.190 & 1.044 & 5.230 & 1.041 & 5.256 & 1.053 & 5.222 & 1.053 \\
\hline 331.0 & 4.679 & 1.040 & 4.703 & 1.039 & 4.719 & 1.054 & 4.750 & 1.040 \\
\hline 381.8 & 4.134 & 1.039 & 4.161 & 1.037 & 4.190 & 1.049 & 4.191 & 1.042 \\
\hline 432.6 & 3.630 & 1.039 & -- & -- & -- & -- & -- & -- \\
\hline $\begin{array}{l}\text { CORE RE } \\
(\text { S.D. })\end{array}$ & ION MEAN & $\begin{array}{l}1.045 \\
(0.005)\end{array}$ & & $\begin{array}{c}1.041 \\
(0.008)\end{array}$ & & $\begin{array}{l}1.049 \\
(0.006)\end{array}$ & & $\begin{array}{c}1.057 \\
(0.013)\end{array}$ \\
\hline
\end{tabular}

A THE THREE MEASUREMENTS AT $Z=12.9$ MM WERE RESPECTIVELY 12.1 MM ABOVE THE DRAWER CENTRE, AT THE DRAWER CENTRE AND 12.9 MM BELOW THE DRAWER CENTRE ( ALONG THE Y-DLMENSION). MATRIX POSITIONS 126-48 AND 171-48 WERE SINGLE-FUEL-COLUMN DRAWERS.

B UNITS OF 10-18 FISSIONS PER ATOM PER SECOND AT A REACTOR POWER OF APPROXIMATELY 1 WATT. ULH QUADRANT = UPPER-LEET-HAND QUADRANT OF ZPPR HALF-ONE ETC. 
TABLE C.14. ZPPR-13A: AXIAL TRAVERSES FOR 235U(N,F) IN FUEL RING 3 AT 60-DEGREES TO THE X-AXIS

\begin{tabular}{|c|c|c|c|c|c|c|c|c|}
\hline \multirow[b]{2}{*}{ Z,MM A } & \multicolumn{2}{|c|}{$\begin{array}{l}\text { MATRIX POSITION } \\
130-39\end{array}$} & \multicolumn{2}{|c|}{$\begin{array}{l}\text { MATRIX POSITION } \\
130-60\end{array}$} & \multicolumn{2}{|c|}{$\begin{array}{l}\text { MATRIX POSITION } \\
167-60\end{array}$} & \multicolumn{2}{|c|}{$\begin{array}{c}\text { MATRIX POSITION } \\
167-39\end{array}$} \\
\hline & EXP. B & $C / E$ & EXP. B & $C / E$ & EXP. B & $C / E$ & EXP. E & $C / E$ \\
\hline & ULH QUAD & RANT & URH QU & RANT & LRH QU & RANT & LLH QU & RANT \\
\hline 12.9 & 6.853 & 1.018 & 6.762 & 1.036 & 6.606 & 1.036 & 6.502 & 1.045 \\
\hline 63.1 & 6.652 & 1.025 & -- & - & -- & -- & -- & -- \\
\hline 77.0 & 6.515 & 1.030 & 6.496 & 1.037 & 6.601 & 1.040 & 6.592 & 1.034 \\
\hline 127.8 & 6.185 & 1.050 & -- & -- & -- & -- & -- & -- \\
\hline 204.0 & 5.819 & 1.029 & - & - & -- & -- & - & $\rightarrow$ \\
\hline 280.2 & 5.177 & 1.023 & 5.195 & 1.024 & 5.264 & 1.030 & 5.250 & 1.025 \\
\hline 331.0 & 4.669 & 1.019 & 4.658 & 1.026 & 4.747 & 1.027 & 4.751 & 1.018 \\
\hline 381.8 & 4.122 & 1.020 & 4.147 & 1.019 & 4.195 & 1.026 & 4.191 & 1.020 \\
\hline 432.6 & 3.673 & 1.008 & -- & -- & - & -- & -- & $-\infty$ \\
\hline $\begin{array}{c}\text { CORE RE } \\
\text { (S.D.) }\end{array}$ & ON MEAN & $\begin{array}{c}1.025 \\
(0.010)\end{array}$ & & $\begin{array}{l}1.029 \\
(0.006)\end{array}$ & & $\begin{array}{c}1.034 \\
(0.007)\end{array}$ & & $\begin{array}{c}1.033 \\
(0.013)\end{array}$ \\
\hline
\end{tabular}

A UNITS OF 10-18 FISSIONS PER ATUM PEK SECUND AI A REACTUR POWER OF APPROXIMATELY 1 WATT. ULH QUADRANT = UPPER-LEFT-HAND QUADRANT OF ZPPR HALF-ONE, ETC. 
TABLE C. 15. ZPPR-13A : REACTION RATE RATIOS ALONG THE X-AXIS

$235 \mathrm{U}(\mathrm{N}, \mathrm{F}) / 239 \mathrm{PU}(\mathrm{N}, \mathrm{F}) \quad 238 \mathrm{U}(\mathrm{N}, \mathrm{G}) / 239 \mathrm{PU}(\mathrm{N}, \mathrm{F}) \quad 238 \mathrm{U}(\mathrm{N}, \mathrm{F}) / 239 \mathrm{PU}(\mathrm{N}, \mathrm{E})$

MATRIX

POS ITION $20 N$

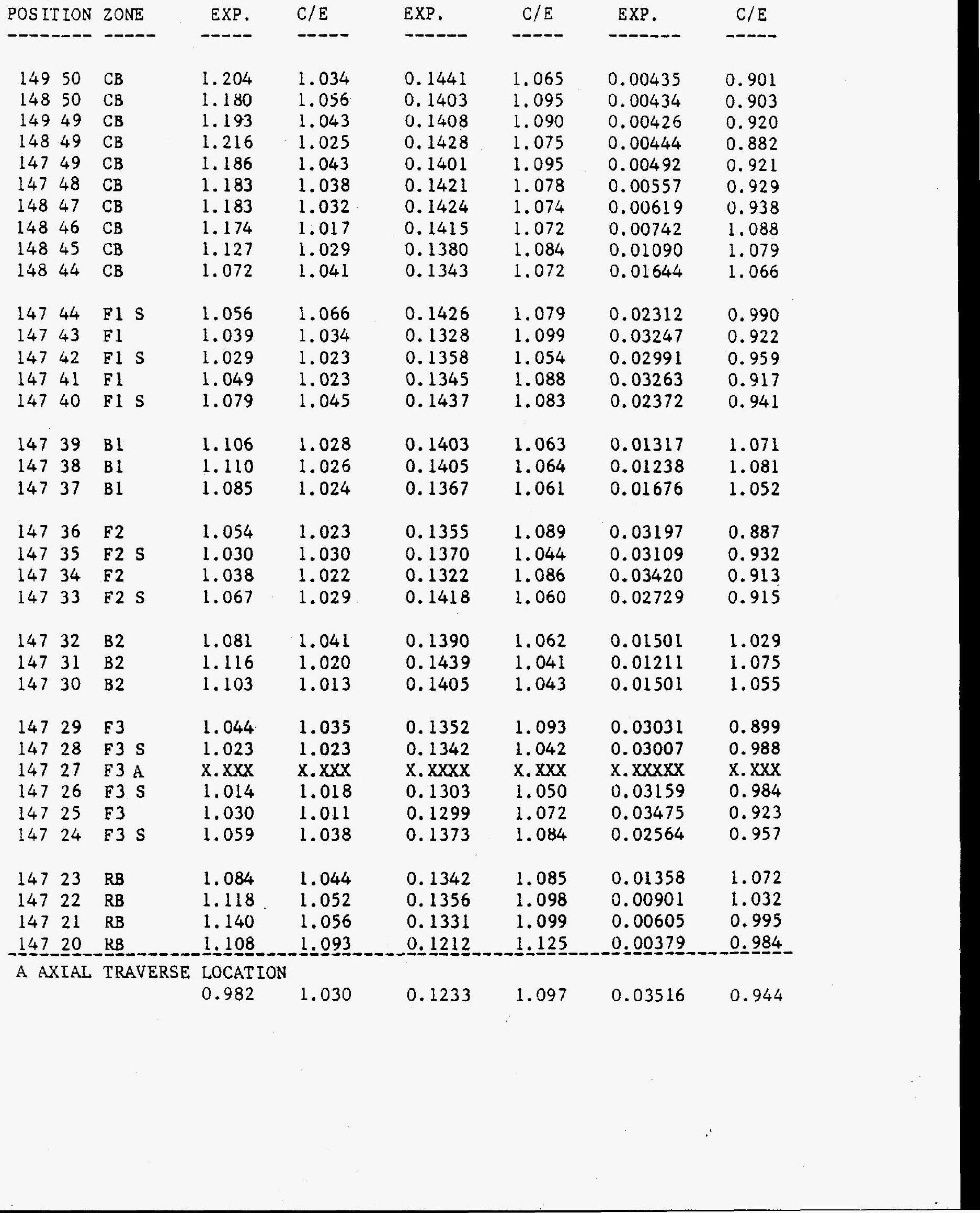


TABLE C.16. ZPPR-13A: REACTION RATE RATIOS ALONG THE Y-AXIS

$235 \mathrm{U}(\mathrm{N}, \mathrm{E}) / 239 \mathrm{PU}(\mathrm{N}, \mathrm{F}) 238 \mathrm{U}(\mathrm{N}, \mathrm{G}) / 239 \mathrm{PU}(\mathrm{N}, \mathrm{F}) 238 \mathrm{U}(\mathrm{N}, \mathrm{F}) / 239 \mathrm{PU}(\mathrm{N}, \mathrm{F})$

MATRIX

POSITION ZONE

EXP. $\quad C / E$

C/E

EXP.

$\mathrm{C} / \mathrm{E}$

$14950 \quad C B$

$14949 \quad \mathrm{CB}$

$14850 \quad \mathrm{CB}$

$14849 \quad \mathrm{CB}$

$14749 \mathrm{CB}$

$14748 \quad \mathrm{CB}$

$14649 \quad \mathrm{CB}$

$14549 \mathrm{CB}$

$14449 \quad C B$

$14349 \mathrm{CB}$

\section{$1.204 \quad 1.034$}

1.193

1.043

0.1441

1.180

1.056

1.216

1.025

1. 186

1.043

1. 183

1.038

$1.150 \quad 1.061$

$1.146 \quad 1.042$

$1.120 \quad 1.036$

1.087

1.026

0.1408

0.1403

0.1428

0.1401

0.1421

0.1395

0.1401

0.1404

0.1358

1.065

0.00435

0.901

1.090

1.095

0.00426

0.920

1.075

0.00434

0.903

1.095

0.00444

0.882

1.078

0.00492

0.921

1.097

0.00557

0.929

1.082

0.00592

0.986

0.00743

1.092

1.064

0.01063

1.114

$14348 \quad$ Fl

1.085

1.039

0.1460

1.060

0.01662

1.064

14248

14148

F1

1.042

1.055

0.02404

0.955

0.1329

1.099

0.03331

0.899

1.027

0.1375

1.051

0.03110

0.922

1.052

0.1360

1.082

0.03319

0.888

13948 F1 S

1.093

1.033

0.1458

1.069

0.02396

0.926

$13848 \quad B 1$

$1.125 \quad 1.011$

0.1411

1.057

0.1398

0.01282

1.093

$13748 \quad B 1$

$1.100 \quad 1.035$

0.1361

1.069

0.01230

1.093

$1.074 \quad 1.034$

1.065

0.01682

1.053

13548

13448
13348

F2 2

$1.032 \quad 1.040$

0.1351

1.085

0.03227

0.898

$1.035 \quad 1.027$

0.1362

1.053

0.1312

1.099

0.03008

0.961

13248

F2 S

$1.011 \quad 1.050$

0.1435

1.055

0.03399

0.909

$13148 \quad$ B 2

$1.095 \quad 1.031$

1.095

0.1404

1.056

0.1415

1.063

0.02667

0.918

$13048 \quad$ B2

1.094

1.043

0.1391

0.01438

1.048

1.056

0.01144

1.113

0.01432

1.086

12848

$1.042 \quad 1.048$

0.1403

1.059

0.02627

0.959

$12748 \quad F 3$

0.982

1.065

0.1249

1. 124

0.03427

0.929

12548 F 3

1.008

0.1299

1.058

0.03217

0.960

1.021

0.1258

1.083

0.03596

0.944

$1.011 \quad 1.032$

0.1287

1.083

0.03503

0.916

12348 F3 S

1.062

0.1380

0.02535

0.962

$12248 \quad R B$

$1.084 \quad 1.046$

1. 096

0.1350

1.080

0.01393

1.024

$1.131 \quad 1.064$

1.074

0.1341

1.110

0.00832

1.095

$12048 \quad R B$

0.1325

1.102

0.00581

1.012

1.067

0.1234

1.094

0.00432

0.829 
TABLE C. 17. 2PPR-13A: REACTION RATE RATIOS IN MATR IX 147-42

\begin{tabular}{|c|c|c|c|c|c|c|c|c|}
\hline \multirow{3}{*}{$\begin{array}{r}\text { MATR IX } \\
\text { POS ITION }\end{array}$} & \multirow[b]{3}{*}{ ZONE } & \multirow[b]{3}{*}{$Z(M M)$} & \multirow{2}{*}{\multicolumn{2}{|c|}{$235 \mathrm{U}(\mathrm{N}, \mathrm{F}) / 239 \mathrm{PU}(\mathrm{N}, \mathrm{F})$}} & \multicolumn{2}{|c|}{$238 \mathrm{U}(\mathrm{N}, \mathrm{G}) / 239 \mathrm{PU}(\mathrm{N}, \mathrm{F})$} & \multicolumn{2}{|c|}{$238 \mathrm{U}(\mathrm{N}, \mathrm{F}) / 239 \mathrm{PU}(\mathrm{N}, \mathrm{F})$} \\
\hline & & & & & $--m--m$ & $-\infty \rightarrow-\infty+\infty$ & $-\infty--\infty-\infty-\infty$ & -ーーーーーーー \\
\hline & & & EXP. & $\mathrm{C} / \mathrm{E}$ & EXP. & $\mathrm{C} / \mathrm{E}$ & EXP. & $C / E$ \\
\hline$-\cdots-\cdots$ & $-\infty$ & $-\cdots-\cdots$ & $-\cdots$ & ---- & $-\cdots+\infty$ & $--\infty-\infty$ & $-\cdots---\infty$ & $-\cdots$ \\
\hline 14742 & Fl S & 77.0 & 1.029 & 1.023 & 0.1358 & 1.054 & 0.02991 & 0.959 \\
\hline 14742 & F1 S & 280.2 & 1.022 & 1.038 & 0.1369 & 1.056 & 0.02895 & 0.978 \\
\hline 14742 & F1 S & 331.0 & 1.011 & 1.058 & 0.1399 & 1.044 & 0.02915 & 0.953 \\
\hline 14742 & F1 S & 381.8 & 1.049 & 1.039 & 0.1404 & 1.064 & 0.02739 & 0.964 \\
\hline 14742 & Fl S & 432.6 & 1.108 & 1.022 & 0.1502 & 1.035 & 0.02488 & 0.924 \\
\hline CORE REGI & LON - & & & $\begin{array}{c}1.034 \\
(0.012)\end{array}$ & & $\begin{array}{c}1.049 \\
(0.010)\end{array}$ & & $\begin{array}{c}0.969 \\
(0.032)\end{array}$ \\
\hline
\end{tabular}


TABLE C. 18. ZPPR-13A: REACTION RATE RATIOS IN MATRIX 147-27

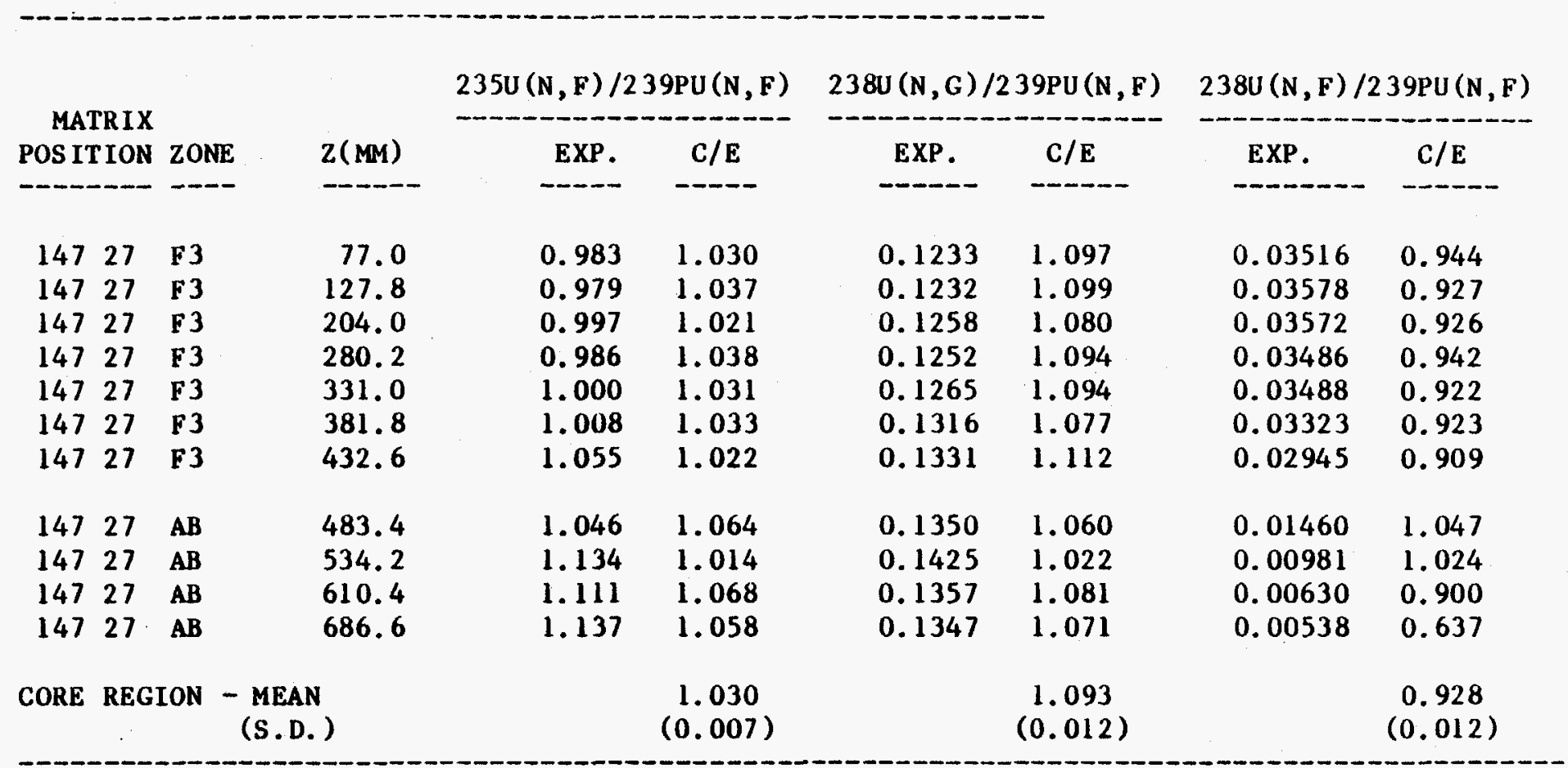


TABLE D.12. ZPPR-13A: AXIAL TRAVERSES IN MATRIX 148-49

\begin{tabular}{|c|c|c|c|c|c|c|c|c|}
\hline \multirow{3}{*}{$\begin{array}{l}\text { MATRIX } \\
\text { POSITION }\end{array}$} & \multirow[b]{3}{*}{ ZONE } & \multirow[b]{3}{*}{$\mathrm{Z}, \mathrm{MM}$} & \multicolumn{2}{|c|}{$235 \mathrm{U}(\mathrm{N}, \mathrm{F})$} & \multicolumn{2}{|c|}{$238 \mathrm{U}(\mathrm{N}, \mathrm{G})$} & \multicolumn{2}{|c|}{$238 \mathrm{U}(\mathrm{N}, \mathrm{F}) \quad \mathrm{B}$} \\
\hline & & & & 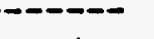 & $\cdots$ & --- & --- & $m-\infty$ \\
\hline & & & EXP. A & $C / E$ & EXP. A & C/E & EXP. A & $C / E$ \\
\hline 14849 & $C B$ & 77.0 & 6.300 & 1.019 & 0.7518 & 1.060 & 0.0214 & 0.934 \\
\hline $148 \quad 49$ & CB & 127.8 & 6.177 & 1.007 & 0.7356 & 1.049 & 0.0216 & 0.894 \\
\hline $148 \quad 49$ & $\mathrm{CB}$ & 204.0 & 5.698 & 1.012 & 0.6776 & 1.054 & 0.0167 & 1.058 \\
\hline $148 \quad 49$ & $C B$ & 280.2 & 4.983 & 1.034 & 0.6024 & 1.054 & 0.0147 & 1.047 \\
\hline $148 \quad 49$ & $C B$ & 331.0 & 4.654 & 1.003 & 0.5496 & 1.043 & 0.0132 & 1.034 \\
\hline $148 \quad 49$ & $C B$ & 381.8 & 4.177 & 0.996 & 0.4845 & 1.048 & 0.0107 & 1.088 \\
\hline $148 \quad 49$ & $C B$ & 432.6 & 3.647 & 0.997 & 0.4209 & 1.047 & 0.0111 & 0.857 \\
\hline $148 \quad 49$ & $C B$ & 483.4 & 3.180 & 0.980 & 0.3601 & 1.040 & 0.0101 & 0.744 \\
\hline $148 \quad 49$ & $C B$ & 534.2 & 2.672 & 0.979 & 0.2989 & 1.042 & 0.0072 & 0.792 \\
\hline $148 \quad 49$ & $\mathrm{CB}$ & 610.4 & 1.936 & 0.991 & 0.2215 & 1.020 & 0.0057 & 0.615 \\
\hline $148 \quad 49$ & $C B$ & 686.6 & 1.345 & 0.961 & 0.1516 & 1.000 & 0.0050 & 0.413 \\
\hline $0-458$ & MM & $\begin{array}{l}\text { MEAN } \\
\text { (S.D.) }\end{array}$ & & $\begin{array}{c}1.010 \\
(0.013)\end{array}$ & & $\begin{array}{c}1.051 \\
(0.006)\end{array}$ & & $\begin{array}{c}0.987 \\
(0.091)\end{array}$ \\
\hline
\end{tabular}

A UNITS OF 10-18 REACTIONS PER ATOM PER SECOND AT A REACTOR POWER OF APPROXIMATELY 1 WATT.

B STATISTICAL UNCERTAINTIES FOR 238U FISSION RANGE FROM 6\% NEAR THE MIDPLANE TO $18 \%$ AT $687 \mathrm{MM}$. 
TABLE D.13. ZPRR-13A: AXIAL TRAVERSES IN MATRIX 148-34

\begin{tabular}{|c|c|c|c|c|c|c|c|c|}
\hline \multirow[b]{2}{*}{ MATRIX } & \multirow[b]{3}{*}{ ZONE } & \multirow[b]{3}{*}{$2, M M$} & \multicolumn{2}{|c|}{$235 U(N, F)$} & \multicolumn{2}{|c|}{$238 \mathrm{U}(\mathrm{N}, \mathrm{G})$} & \multicolumn{2}{|c|}{$238 U(N, F)$} \\
\hline & & & $-\cdots-\cdots$ & $-\cdots$ & $-\infty-\cdots-\infty$ & $-\cdots$ & $-\cdots--$ & $-\cdots$ \\
\hline POSITION & & & EXP. A & $C / E$ & EXP. A & $C / E$ & EXP. A & $C / E$ \\
\hline - & $\cdots$ & $-\infty$ & $--\infty$ & $--\infty$ & $-\ldots-$ & & $--\infty$ & $--\infty$ \\
\hline $148 \quad 34$ & F2 S & $77.0 \mathrm{C}$ & 8.558 & 1.027 & 1.1510 & 1.045 & 0.2191 & 0.948 \\
\hline 14834 & F2 $\mathrm{s}$ & 127.8 & 8.316 & 1.011 & $1.1590 \mathrm{D}$ & 1.006 & 0.1949 & $1.030 \mathrm{I}$ \\
\hline $148 \quad 34$ & F2 $\mathrm{s}$ & 204.0 & 7.675 & 1.012 & 1.0330 & 1.043 & 0.1962 & 0.942 \\
\hline $148 \quad 34$ & F2 $\mathrm{S}$ & 280.2 & 6.750 & 1.021 & 0.9187 & 1.043 & 0.1677 & 0.963 \\
\hline $148 \quad 34$ & F2 $\mathrm{S}$ & 331.0 & 6.126 & 1.016 & 0.8422 & 1.029 & 0.1456 & 0.972 \\
\hline 14834 & E2 S & 381.8 & 5.486 & 1.009 & 0.7509 & 1.029 & 0.1267 & 0.930 \\
\hline $148 \quad 34$ & E2 $\mathrm{s}$ & 432.6 & 4.878 & 1.007 & 0.6620 & 1.036 & 0.0939 & 0.940 \\
\hline 14834 & $A B$ & 483.4 & 4.408 & 1.036 & 0.5521 & 1.064 & 0.0448 & 1.064 \\
\hline $148 \quad 34$ & $A B$ & 534.2 & 3.888 & 1.033 & 0.4702 & 1.075 & 0.0260 & 1.034 \\
\hline $148 \quad 34$ & $\mathrm{AB}$ & 610.4 & 3.057 & 1.015 & 0.3658 & 1.040 & 0.0147 & 0.798 \\
\hline $148 \quad 34$ & $A B$ & 686.6 & 2.187 & 1.035 & 0.2590 & 1.042 & 0.0069 & 0.763 \\
\hline $0-458$ & MM & $\begin{array}{l}\text { MEAN } \\
\text { (S.D.) }\end{array}$ & & $\begin{array}{c}1.015 \\
(0.007)\end{array}$ & & $\begin{array}{c}1.038 \\
(0.007)\end{array}$ & & $\begin{array}{c}0.949 \\
(0.016)\end{array}$ \\
\hline
\end{tabular}

A UNITS OF 10-18 REACTIONS PER ATOM PER SECOND AT A REACTOR POWER OF APPROXIMATELY

1 WATT.

B STATISTICAL UNCERTAINTIES FOR 238U FISSION IN THE AXIAL BLANKET RANGE FROM 3\% TO $20 \%$.

C THE $235 U$ FOIL WAS LOCATED AT $Z=63.1 \mathrm{MM}$, THE $238 \mathrm{U}$ FOIL WAS LOCATED AT $Z=77.0 \mathrm{MM}$.

D THESE FOILS WERE LOCATED AT THE END OF A FUEL PLATE. THE FOIL/CELL-AVERAGE FACTORS ARE NOT APPROPRIATE AND THE DATA SHOULD BE DISCARDED. 
TABLE D.14. ZPPR-13A: AXIAL TRAVERSES IN MATRIX 148-31

\begin{tabular}{|c|c|c|c|c|c|c|c|c|}
\hline MATRIX & \multirow[b]{2}{*}{ ZONE } & \multirow[b]{2}{*}{$\mathrm{Z}, \mathrm{MM}$} & \multicolumn{2}{|c|}{$235 U(N, F)$} & \multicolumn{2}{|c|}{$238 U(N, G)$} & \multicolumn{2}{|c|}{$238 \mathrm{U}(\mathrm{N}, \mathrm{F}) \mathrm{B}$} \\
\hline $\begin{array}{c}\text { MATRIX } \\
\text { POSITION }\end{array}$ & & & EXP. A & $C / E$ & EXP. A & $C / E$ & EXP. A & $C / E$ \\
\hline - - - - - & -- & --- & ---- & $-\infty$ & - - & $-\infty$ & ---- & ---- \\
\hline $\begin{array}{ll}148 & 31 \\
148 & 31 \\
148 & 31 \\
148 & 31 \\
148 & 31 \\
148 & 31 \\
148 & 31\end{array}$ & $\begin{array}{l}\text { B2 } \\
\text { B2 } \\
\text { B2 } \\
\text { B2 } \\
\text { B2 } \\
\text { B2 } \\
\text { B2 }\end{array}$ & $\begin{array}{r}77.0 \mathrm{C} \\
127.8 \\
204.0 \\
280.2 \\
331.0 \\
381.8 \\
432.6\end{array}$ & $\begin{array}{l}7.820 \\
7.681 \\
7.122 \\
6.281 \\
5.595 \\
5.001 \\
4.379\end{array}$ & $\begin{array}{l}1.043 \\
1.023 \\
1.021 \\
1.030 \\
1.045 \\
1.040 \\
1.042\end{array}$ & $\begin{array}{l}0.9947 \\
0.9696 \\
0.8972 \\
0.7925 \\
0.7193 \\
0.6358 \\
0.5598\end{array}$ & $\begin{array}{l}1.076 \\
1.069 \\
1.067 \\
1.072 \\
1.064 \\
1.065 \\
1.052\end{array}$ & $\begin{array}{l}0.0770 \\
0.0761 \\
0.0713 \\
0.0618 \\
0.0531 \\
0.0460 \\
0.0356\end{array}$ & $\begin{array}{l}1.124 \\
1.099 \\
1.077 \\
1.081 \\
1.097 \\
1.051 \\
1.042\end{array}$ \\
\hline $\begin{array}{ll}148 & 31 \\
148 & 31 \\
148 & 31 \\
148 & 31\end{array}$ & $\begin{array}{l}\text { B2 } \\
\text { B2 } \\
\text { B2 } \\
\text { B2 }\end{array}$ & $\begin{array}{l}483.4 \\
534.2 \\
610.4 \\
686.6\end{array}$ & $\begin{array}{l}3.910 \\
3.285 \\
2.456 \\
1.700\end{array}$ & $\begin{array}{l}1.010 \\
1.020 \\
1.017 \\
1.014\end{array}$ & $\begin{array}{l}0.4744 \\
0.3923 \\
0.2895 \\
0.1924\end{array}$ & $\begin{array}{l}1.060 \\
1.071 \\
1.058 \\
1.081\end{array}$ & $\begin{array}{l}0.0268 \\
0.0185 \\
0.0095 \\
0.0063\end{array}$ & $\begin{array}{l}0.963 \\
0.907 \\
0.884 \\
0.643\end{array}$ \\
\hline $0-458$ & MM & $\begin{array}{l}\text { MEAN } \\
\text { (S.D.) }\end{array}$ & & $\begin{array}{c}1.035 \\
(0.010)\end{array}$ & & $\begin{array}{c}1.066 \\
(0.008)\end{array}$ & & $\begin{array}{c}1.082 \\
(0.028)\end{array}$ \\
\hline
\end{tabular}

A UNITS OF 10-18 REACTIONS PER ATOM PER SECOND AT A REACTOR POWER OF APPROXIMATELY

1 WATT.

B STATISTICAL UNCERTAINTIES FOR 238U FISSION IN THE AXIAL BLANKET RANGE FROM 3\% TO $20 \%$.

C THE 2350 FOIL WAS LOCATED AT $Z=63.1 \mathrm{MM}$, THE $238 \mathrm{U}$ FOIL WAS LOCATED AT $Z=77.0 \mathrm{MM}$. 
TABLE_D.15._ZPPR-13A:_REACTION_RATE_RATIOS_ALONG_THE X-AXIS

$$
235 \mathrm{U}(\mathrm{N}, \mathrm{F}) / 239 \mathrm{PU}(\mathrm{N}, \mathrm{F}) \quad 238 \mathrm{U}(\mathrm{N}, \mathrm{G}) / 239 \mathrm{PU}(\mathrm{N}, \mathrm{F}) \quad 238 \mathrm{U}(\mathrm{N}, \mathrm{F}) / 239 \mathrm{PU}(\mathrm{N}, \mathrm{F})
$$

\section{MATRIX}

POSITIO

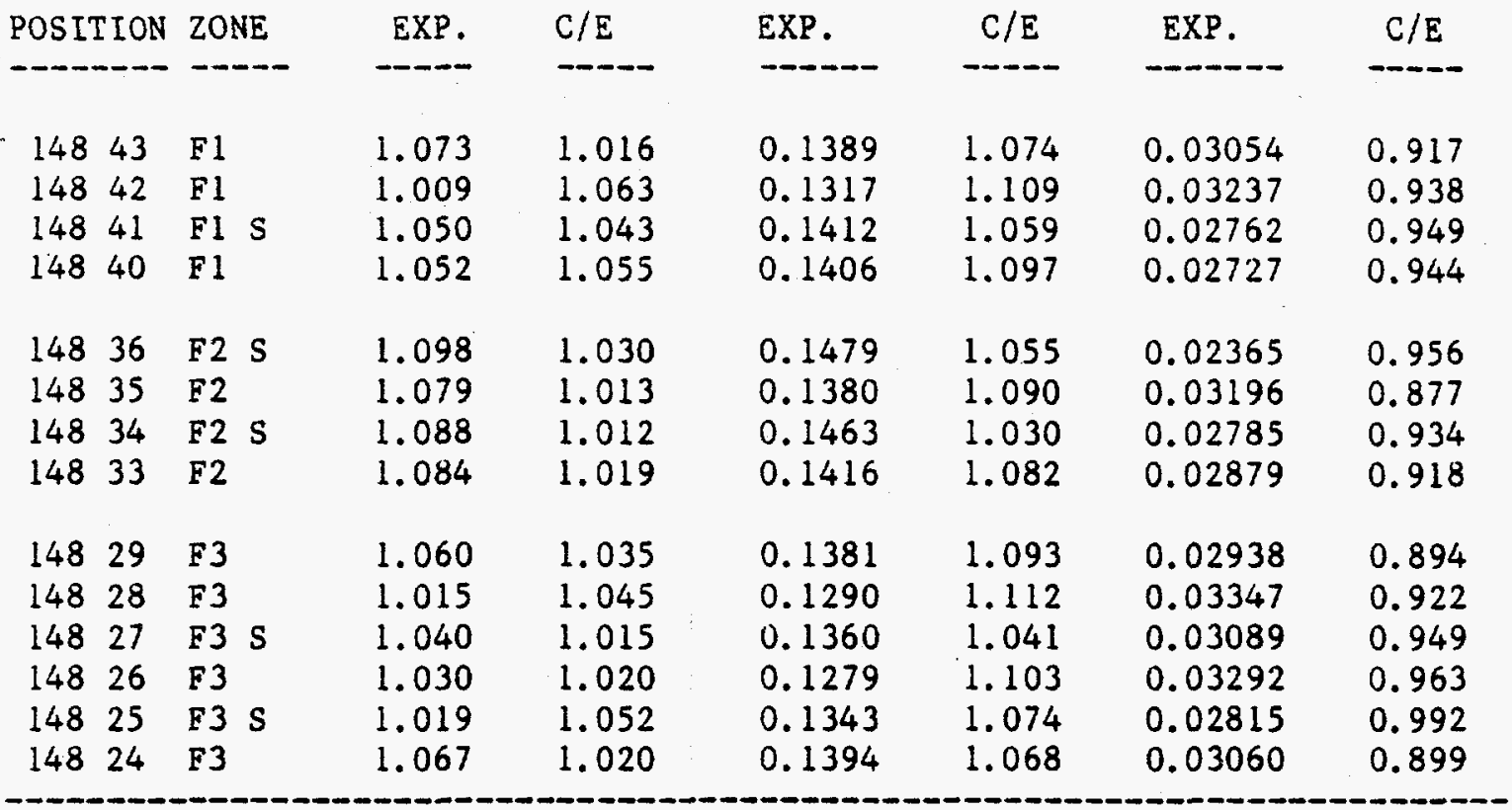

